\title{
28. BIOGENIC OPAL AND CARBONATE ACCUMULATION RATES IN THE SUBANTARCTIC SOUTH ATLANTIC: THE LATE NEOGENE OF METEOR RISE SITE 704
}

\author{
P. N. Froelich, ${ }^{2}$ P. N. Malone, ${ }^{2}$ D. A. Hodell,${ }^{3}$ P. F. Ciesielski, ${ }^{3}$ D. A. Warnke,${ }^{4}$ F. Westall, ${ }^{5}$ E. A. Hailwood, ${ }^{6}$ \\ D. C. Nobes, ${ }^{7}$ J. Fenner, ${ }^{8}$ J. Mienert, ${ }^{8}$ C. J. Mwenifumbo, ${ }^{9}$ and D. W. Müller ${ }^{10}$
}

\begin{abstract}
A preliminary composite depth section was generated for Site 704 by splicing Holes 704A and 704B together over the interval 0-350 mbsf (0-9 m.y.). High-resolution carbonate and opal data from the cores were correlated with the calcium and silicon signals from the GST logging run in Hole 704B to identify missing and disturbed intervals in the cores. Paleomagnetic and biostratigraphic age boundaries were then transferred to the composite depth records to obtain an age model, and sedimentation rates were calculated by linear interpolation between datums. Algorithms relating measured dry-bulk density to carbonate content and depth were generated to produce predicted values of density for every sample. Accumulation rates of bulk, carbonate, opal, and terrigenous sediment components were then computed to generate a record of sediment deposition on the Meteor Rise that has a resolution of better than $200,000 \mathrm{yr}$ for the period from 8.6 to $1.0 \mathrm{~m} . \mathrm{y}$.

From 8.6 to 2.5 m.y., bulk-accumulation rates on the Meteor Rise averaged less than $2 \mathrm{~g} / \mathrm{cm}^{2} / 1000 \mathrm{yr}$ and were dominated by carbonate deposition. The first significant opal deposition $(6.0 \mathrm{~m} . \mathrm{y}$.) punctuated a brief (less than 0.6 Ma) approach of the Polar Front Zone (PFZ) northward that heralded a period of increasing severity of periodic carbonate dissolution events (terrigenous maxima) that abruptly terminated at $4.8 \mathrm{~m} . \mathrm{y}$. (base of the Thvera Subchron), synchronous with the reflooding of the Mediterranean after the Messinian salinity crisis. From 4.8 to 2.5 m.y., carbonate again dominated deposition, and the PFZ was far south except during brief northward excursions bracketing 4.2-3.9, 3.3-2.9, and 2.8-2.7 m.y. At $2.5 \mathrm{~m}$.y., all components of bulk-accumulation rates increased dramatically (up to $15 \mathrm{~g} / \mathrm{cm}^{2} / 1000 \mathrm{yr}$ ), and by $2.4 \mathrm{~m} . \mathrm{y}$., a pattern of alternating, high-amplitude carbonate and opal cyclicity marked the initiation of rapid glacial to interglacial swings in the position of the PFZ, synchronous with the "onset" of major Northern Hemisphere glaciation. Both mass-accumulation rates and the amplitude of the cycles decreased by about $2 \mathrm{~m}$.y., but opal accumulation rates remained high up through the base of the Jaramillo (0.98 m.y.). From 1.9 to $1 \mathrm{~m} . y$. , the record is characterized by moderate amplitude fluctuations in carbonate and opal.

This record of opal accumulation rates is interpreted as a long-term "Polar Front Indicator" that monitors the advance and retreat of the opal-rich PFZ northward (southward) toward (away from) the Meteor Rise in the subantarctic sector of the South Atlantic Ocean. The timing of PFZ migrations in the subantarctic South Atlantic Ocean is remarkably similar to Pliocene-Pleistocene climate records deduced from benthic oxygen isotope records in the North Atlantic Ocean (Raymo et al., 1989; Ruddiman et al., 1989). These include northward migrations during "cold" intervals containing strong glacial isotope stages $(2.4-2.3,2.1-2.0,1.95-1.55,1.45-1.30 \mathrm{~m}$.y. and at about 1.13 and 1.09 m.y.) and southward migrations during "warm" intervals containing weak glacial and/or strong interglacial stages $(2.45-2.40,2.30-2.10,2.00-1.95,1.52-1.45,1.30-1.18,1.11$, and $1.06-0.93 \mathrm{~m} . \mathrm{y}$. $)$. Although our preliminary composite record is not continuous (some stages are obviously missing), there is hope that future work will identify these missing intervals in the as yet incomplete Hole 704B and will extend this high-resolution Southern Hemisphere climate record back to $8.6 \mathrm{~m}$.y.
\end{abstract}

\section{INTRODUCTION}

Ocean Drilling Program (ODP) Site $704 \quad\left(46^{\circ} 52.8^{\prime} \mathrm{S}\right.$, $07^{\circ} 25.3^{\prime} \mathrm{E}$ ) was drilled in the southeastern subantarctic Atlantic Ocean on the Meteor Rise at a water depth of $2532 \mathrm{~m}$. This

\footnotetext{
${ }^{1}$ Ciesielski, P. F., Kristoffersen, Y., et al., 1991. Proc. ODP, Sci. Results, 114: College Station, TX (Ocean Drilling Program).

${ }_{2}^{2}$ Lamont-Doherty Geological Observatory, Columbia University, NY 10964

3 Department of Geology, University of Florida, Gainesville, FL 32611

${ }^{4}$ Department of Geological Sciences, California State University, Hayward, CA 94542.

${ }_{5}^{5}$ Sciences de la Terre, Université de Nantes, F-44072 Nantes Cedex, France.

${ }^{6}$ Department of Oceanography, Southampton University, Southampton SO9 5 NH, U.K.

${ }_{7}^{7}$ Department of Physics and Quaternary Sciences Institute, University of Waterloo, Waterloo, Ontario N2L 3G1, Canada. FRG.

${ }^{8}$ Geol.-Paläontol. Institut and GEOMAR, Kiel Universität, D-2300 Kiel,

${ }^{9}$ Geological Survey of Canada, 601 Booth St., Ottawa, Ontario K1A 0E4, Canada.

${ }^{10}$ Geologisches Institut, ETH-Zentrum, CH-8092 Zürich, Switzerland.
}

site is just north of the present axis of the Polar Front Zone (PFZ), an oceanic boundary with steep temperature, nutrient, and productivity gradients in surface waters that overlies a marked lithologic boundary in surficial sediments dividing calcareous oozes to the north from biosiliceous oozes to the south. We thus anticipated that sediments on the Meteor Rise would provide a monitor of latitudinal migrations in the PFZ linked to climate change through the late Cenozoic. This site lies today in upper deep waters that are a mixture of Circumpolar Deep Water (CPDW) and North Atlantic Deep Water (NADW). As such, it also represents a nexus for the interchange of deep water masses between the North Atlantic and IndoPacific Oceans.

Accumulation rates of biogenic components in marine sediments, such as carbonate, opal (biosilica), and organic carbon, can be related both to the productivity of overlying waters and to factors that control their destruction in the deep ocean and ultimate preservation into the sediment column (Broecker and Peng, 1982). These factors are complicated and not well understood even for the present ocean. Thus, paleoceanographic reconstructions have generally considered that variations of pelagic carbonate accumulation 
are linked both to the balance between preservation and dissolution below the lysocline and to changes in carbonate production in overlying surface waters. Often, dramatic decreases in sedimentary carbonate contents are taken to reflect shoaling in the depth of the carbonate lysocline or carbonate compensation depth (CCD) and thus to monitor the chemical state of deep waters (Farrell and Prell, 1989). On the other hand, opal accumulation rates can be linked more directly to biosiliceous (diatom) paleoproductivity because the rate of dissolution of biosiliceous debris in the deep ocean is not dependent on water depth or chemistry but rather on rates of accumulation of other phases. As such, opal accumulation records the supply of nutrients via upwelling to surface waters and thus provides a monitor of deep- and surface-ocean exchange, the nutrient content of deep waters reaching the surface, and local effects such as the position and strength of divergences (Leinen et al., 1986; Lyle et al., 1988; Pisias and Leinen, 1984; and others).

In this paper, we will present a preliminary attempt to produce a composite record for the late Neogene at Site 704 and provide evidence for its completeness (or lack thereof) by correlating the carbonate and opal records of the composite section with the calcium and silicon records produced by the logging run (GST) in Hole 704B. We then transfer the magnetostratigraphic and biostratigraphic ages into the composite record and calculate accumulation rates of biogenic and terrigenous fractions. The paleoceanographic implications of these results will be briefly discussed in terms of migrations of the Polar Front Zone.

\section{METHODS}

\section{Analytical}

About 700 carbonate determinations were made aboard ship with a Coulometrics Carbon Analyzer by measurement of the carbon dioxide liberated upon acidification of a sample. These data were supplemented by laboratory carbonate data generated at the University of Florida, the Alfred Wegener Institute for Polar Studies, and Lamont-Doherty Geological Observatory (Jones and Kaiteris, 1983). Opal was determined at Lamont-Doherty by the single-step alkaline extraction method of Mortlock and Froelich (in press). Percent opal is calculated as \% Si extracted into solution multiplied by 2.4 , which includes the waters of hydration in opaline silica $\left(\mathrm{SiO}_{2}\right.$ - $0.4 \mathrm{H}_{2} \mathrm{O}$ ). The relative precision of these data is $\pm 2 \%$ for carbonate and $\pm 4 \%$ for opal. The terrigenous fraction is estimated by difference: $100 \%-\% \mathrm{CaCO}_{3}-\%$ opal $=\%$ other. Percent carbonate, opal, and other data were computed on a dry-weight basis without correction for dry sea-salt content and are presented in the Appendix.

\section{Composite Section and Logging Correlation}

Because of the high seas that JOIDES Resolution encountered during coring parts of the two holes at Site 704 and because of the highly porous unconsolidated nature of the uppermost $100 \mathrm{~m}$ of the section, there is a high probability for significant drilling disturbance and significant missing sections between core breaks. Unfortunately, throughout much of the upper section, the core breaks in Holes 704A and 704B fall within the same lithostratigraphic intervals. Shipboard visual inspection of cores as they came on deck indicated that the interval between about 20 and 40 mbsf in Hole 704A was highly disturbed, prompting us to sample Hole 704B at high resolution across this interval. There is also the possibility of downhole slumping, leading to displaced sections at the tops of some cores, which are difficult to identify unless distinctly out of place.
One method of discovering and potentially correcting for coring problems is to compare the high-resolution carbonate and opal records determined from the cores with the logging record obtained with the GST (geochemical tool), which senses (among other things) calcium and silicon (see Mwenifumbo and Blangy, this volume, for a full description of the logging runs in Hole 704B). Because of the rhythmic cyclicity of carbonate and biosiliceous oozes at Site 704, the GST signals are large and can be readily correlated with the core data. Because of deteriorating hole conditions, the GST tool was run through the pipe, which tends to attenuate the chemostratigraphic signal because of the thickness of the pipe wall. Signal attenuation is most evident in the upper $20-30 \mathrm{~m}$ below seafloor (mbsf) where the formation was apparently displaced from the pipe.

Unfortunately, the field logging tapes from Leg 114 were misplaced, delaying the normal shorebased processing to produce a better quality record of the logging data. Working from a digitized record of the shipboard-processed logging data sampled at $0.15-\mathrm{m}$ intervals, we generated downhole records of the ratios of the $\mathrm{Ca}$ to $\mathrm{Si}$ yields in an attempt to minimize interferences (hoping that any residual interferences would cancel) and to mimic the core records of carbonate and silica. Thus the GST logging records presented here are in the form $\mathrm{Ca} /(\mathrm{Ca}+\mathrm{Si})$ and $\mathrm{Si} /(\mathrm{Ca}+\mathrm{Si})$, where $\mathrm{Ca}$ and $\mathrm{Si}$ reflect the gamma-ray yields after shipboard processing. The resulting data set should be viewed with caution. Note that $\mathrm{Ca} /(\mathrm{Ca}$ $+\mathrm{Si})$ is the mathematical complement of $\mathrm{Si} /(\mathrm{Ca}+\mathrm{Si})$ so that the two logging records are exact mirror images.

Detailed logging records for $\mathrm{Ca}$ ratios and $\mathrm{Si}$ ratios in Hole 704B were plotted downhole next to the expanded core records for percent carbonate and for percent opal plus other (terrigenous) in Holes 704A and 704B (these plots are not shown here). We used the core records of sum of opal plus other (rather than just opal) as a proxy indicator for silicon content in an attempt to mimic $\mathrm{Si} /(\mathrm{Ca}+\mathrm{Si})$ because opal is $40 \%$ silicon and terrigenous material is $30 \%$ to $50 \%$ silicon. The resulting opal plus other signal has a scaled amplitude that parallels that of $\mathrm{Si} /(\mathrm{Ca}+\mathrm{Si})$. The obvious advantage of this procedure is to enable signal correlation of the logging record both with clay layers (carbonate-dissolution intervals rich in terrigenous material) and with biosiliceous intervals (opal rich). These expanded plots were used to guide us in constructing a composite section by comparing the core records with the logging record over comparable depth domains.

For all three records (the core records of Holes 704A and $704 \mathrm{~B}$ and the logging records in Hole 704B), we used the reported shipboard depths in meters below seafloor with core breaks shown explicitly. Because core recovery was often greater than $100 \%$ (measured core lengths are longer than the nominal $9.5 \mathrm{~m}$ of piston core advance assigned by the drillers), the depths of core breaks commonly correspond to depth intervals over which the reported sub-bottom depths of tops and bottoms of adjacent cores overlap. In the following construction of a composite section we eliminate the overlap problem by adjoining cores end to end and recalculating sub-bottom depth as the sum of measured core lengths.

\section{Composite Section}

In order to compare the core records with the GST logs, we first spliced Holes 704A and 704B together using color changes and markers visible in both holes (Table 1). A major assumption in this process is that because the two holes were offset by only $10 \mathrm{~m}$, they are stratigraphically identical. The only purpose of these initial splices was to replace the obviously disturbed interval in Hole 704A (20-40 mbsf) and to continue the record below the useful portion of Hole $704 \mathrm{~A}$ 
Table 1. Color correlations, Holes $704 \mathrm{~A}$ and $704 B$.

\begin{tabular}{lcc}
\hline & \multicolumn{2}{c}{ Depth } \\
\cline { 2 - 3 } $\begin{array}{c}\text { Color } \\
\text { change }\end{array}$ & $\begin{array}{c}\text { Hole 704A } \\
\text { (mbsf) }\end{array}$ & $\begin{array}{c}\text { Hole 704B } \\
\text { (mbsf) }\end{array}$ \\
\hline C1 & 2.40 & 1.90 \\
C2 & 5.50 & 5.70 \\
C3 & 6.95 & 6.80 \\
C4 & 14.20 & 11.40 \\
C5 & 41.40 & 40.20 \\
C6 & 43.47 & 42.71 \\
C7 & 45.20 & 44.20 \\
C8 & 48.92 & 50.80 \\
C9 & 55.10 & 57.80 \\
C10 & 68.05 & 67.41 \\
C11 & 69.20 & 68.31 \\
C12 & 69.80 & 68.70 \\
C13 & 75.96 & 78.95 \\
C14 & 84.99 & 88.20 \\
C15 & 86.40 & 91.50 \\
C16 & 219.65 & 221.30 \\
C17 & 220.70 & 222.20 \\
C18 & 223.80 & 223.90 \\
C19 & 228.30 & 227.95 \\
\hline
\end{tabular}

with that of Hole 704B (below about $234 \mathrm{mbsf}$ ). No attempt was made at this stage to correct for other disturbed, missing, or re-cored intervals or to replace missing intervals in core breaks. We anticipate that a more complete road map with identifiable missing intervals spliced between holes will be possible after the field logging tapes are processed and detailed carbonate and opal analyses and biostratigraphic workups of Hole 704B are completed.

We spliced Holes 704A and 704B together at three depths to produce a composite depth section: (1) at color change $\mathrm{C} 4$, which corresponds to the middle of a multiple carbonate peak; (2) at color change $\mathrm{C} 7$, which corresponds to a carbonate maximum; and (3) at color change C18 near the bottom of Hole 704A, which corresponds to the middle of a set of carbonate minima. These color changes are visible in both holes and do not coincide with core breaks. The top of Hole $704 \mathrm{~A}$ was set to 0 mbsf and the length of each core was set to its true recovered length as reported by the shipboard scientific party (Ciesielski, Kristoffersen, et al., 1988). The core lengths were then added from top to bottom through the composite section, and sub-bottom depths were recalculated from the top of the hole downward without collapsing voids. A core-by-core road map of the composite section with the splices, reported sub-bottom depths, additions (or deletions) to sub-bottom depths, and depth in the composite section is presented in Table 2. All subsequent sub-bottom depths reported for this composite section will be labeled mbT (meters below top). The composite depth records of carbonate and opal plus other in the composite section are plotted next to their analogous logging records in Figures 1 and 2. The sampling density for carbonate data in this composite section averages about one per $2000 \mathrm{yr}$ between 0 and $2.47 \mathrm{~m}$.y. (at 14-cm intervals between 0 and $168 \mathrm{mbT}$ ) and one per $8000 \mathrm{yr}$ between 2.47 and 8.64 m.y. (at $20-\mathrm{cm}$ intervals between 168 and $327 \mathrm{mbT}$ ). The sampling density for opal and other data averages about one-third that of the carbonate data over the same intervals.

\section{Correlation of Logs and Core Records}

Visual comparison of the expanded logging and core records suggests that the uppermost $6 \mathrm{~m}$ may be missing in the logging run and that the logging record appears systematically 4 to $6 \mathrm{~m}$ shallower than the shipboard-reported core depths throughout
Table 2. Road map and splices in Holes 704A and 704B to produce the composite depth section for Site 704.

\begin{tabular}{|c|c|c|c|}
\hline $\begin{array}{l}\text { Core, section, } \\
\text { interval }(\mathrm{cm})\end{array}$ & $\begin{array}{l}\text { Depth } \\
\text { (mbsf) }\end{array}$ & $\begin{array}{c}\text { Offset } \\
(\mathrm{m})\end{array}$ & $\begin{array}{l}\text { Composite } \\
\text { depth (mbT) }\end{array}$ \\
\hline $\begin{array}{l}114-704 \mathrm{~A}- \\
1 \mathrm{H}-1 \text { (top) }\end{array}$ & $0-7.2$ & +0.00 & $0-7.28$ \\
\hline 2H-5 (bottom) & $7.2-14.7$ & +0.08 & $7.28-14.78$ \\
\hline \multicolumn{4}{|c|}{$704 \mathrm{~A} \rightarrow 704 \mathrm{~B}$ Splice at color boundary C4 } \\
\hline $\begin{array}{l}114-704 \mathrm{~B}- \\
2 \mathrm{H}-4 \text { (top) } \\
3 \mathrm{H} \\
4 \mathrm{H} \\
5 \mathrm{H}-7 \text { (bottom) }\end{array}$ & $\begin{array}{l}11.2-16.2 \\
16.2-25.7 \\
25.7-35.2 \\
35.2-44.7\end{array}$ & $\begin{array}{l}+3.58 \\
+2.17 \\
+2.70 \\
+1.92\end{array}$ & $\begin{array}{l}14.78-18.37 \\
18.37-28.40 \\
28.40-37.12 \\
37.12-46.64\end{array}$ \\
\hline \multicolumn{4}{|c|}{$704 B \rightarrow 704$ A Splice at color boundary C7 } \\
\hline $\begin{array}{l}114-704 \mathrm{~A}- \\
6 \mathrm{H}-1 \text { (top) } \\
7 \mathrm{H} \\
8 \mathrm{H} \\
9 \mathrm{H} \\
10 \mathrm{H} \\
11 \mathrm{H} \\
12 \mathrm{H} \\
13 \mathrm{H} \\
14 \mathrm{H} \\
15 \mathrm{H} \\
16 \mathrm{H} \\
17 \mathrm{X} \\
18 \mathrm{X} \\
19 \mathrm{X} \\
20 \mathrm{X} \\
21 \mathrm{X} \\
22 \mathrm{X} \\
23 \mathrm{X} \\
24 \mathrm{X}-6 \text { (bottom) }\end{array}$ & $\begin{array}{c}45.2-54.7 \\
54.7-64.2 \\
64.2-73.7 \\
73.7-83.2 \\
83.2-92.7 \\
92.7-102.2 \\
102.2-111.7 \\
111.7-121.2 \\
121.1-130.7 \\
130.7-140.2 \\
140.2-149.7 \\
149.7-159.2 \\
159.2-168.7 \\
168.7-178.2 \\
178.2-187.7 \\
187.2-197.2 \\
197.2-206.7 \\
206.7-216.2 \\
216.2-225.7\end{array}$ & $\begin{array}{l}+1.44 \\
+1.94 \\
+1.29 \\
+0.81 \\
+0.91 \\
+1.47 \\
+1.78 \\
+1.44 \\
+1.72 \\
+0.80 \\
+1.08 \\
+0.28 \\
-0.01 \\
-0.67 \\
-0.58 \\
+0.10 \\
-4.23 \\
-5.60 \\
-7.00\end{array}$ & $\begin{array}{c}46.64-56.64 \\
56.64-65.49 \\
65.49-74.51 \\
74.51-84.11 \\
84.11-94.17 \\
94.17-103.98 \\
103.98-113.14 \\
113.14-122.92 \\
122.92-131.50 \\
131.50-141.28 \\
141.28-149.98 \\
149.98-159.19 \\
159.19-168.03 \\
168.03-177.62 \\
177.62-187.30 \\
187.30-192.97 \\
192.97-201.10 \\
201.10-209.20 \\
209.20-217.31\end{array}$ \\
\hline \multicolumn{4}{|c|}{$704 \mathrm{~A} \rightarrow 704 \mathrm{~B}$ Splice at color boundary C18 } \\
\hline $\begin{array}{l}114-704 B- \\
25 X-1,70 \\
26 X \\
27 X \\
28 X \\
29 X \\
30 X \\
31 X \\
32 X \\
33 X \\
34 X \\
35 X \\
36 X \\
37 X\end{array}$ & $\begin{array}{l}223.9-232.7 \\
232.7-242.2 \\
242.2-251.7 \\
251.7-261.2 \\
261.2-270.7 \\
270.7-280.2 \\
280.2-289.7 \\
289.7-299.2 \\
299.2-308.7 \\
308.7-318.2 \\
318.2-327.7 \\
327.7-337.2 \\
337.2-346.7\end{array}$ & $\begin{array}{r}-6.64 \\
-6.23 \\
-8.75 \\
-8.31 \\
-7.99 \\
-7.77 \\
-6.85 \\
-6.63 \\
-6.12 \\
-5.73 \\
-5.28 \\
-4.80 \\
-10.24\end{array}$ & $\begin{array}{l}217.31-226.47 \\
226.47-233.45 \\
233.45-243.39 \\
243.39-253.21 \\
253.21-262.93 \\
262.93-273.35 \\
273.35-283.07 \\
283.07-293.08 \\
293.08-302.97 \\
302.97-312.92 \\
312.92-322.90 \\
322.90-326.96 \\
326.96-336.46\end{array}$ \\
\hline
\end{tabular}

the upper $220 \mathrm{mbsf}$. In contrast, Holes 704A and 704B appear to be of approximately equivalent depth, with only a 1 to $2 \mathrm{~m}$ difference that migrates through the section. As a preliminary attempt to evaluate this depth difference between cores and logs, we correlated the carbonate record for the composite Site 704 record with the logging record for $\mathrm{Ca} /(\mathrm{Ca}+\mathrm{Si})$ after tying the two records together at the one depth where visual comparisons indicated an unequivocal match: the uppermost minimum of a set of strong multiple carbonate minima that occurs at $215.2 \mathrm{mbsf}$ in the Site $704 \log$ and at $212.7 \mathrm{mbT}$ in the Site 704 composite section. This horizon coincides with color marker $\mathrm{C} 16$, which occurs at 219.7 mbsf in Hole 704A and at $221.3 \mathrm{mbsf}$ in Hole $704 \mathrm{~B}$. Correlations were performed using the $\mathrm{Ca} /(\mathrm{Ca}+\mathrm{Si})$ logging record as target by the inverse method of Martinson et al. (1982) with the Lamont-Doherty Geological Observatory Core Pack program. This mapping confirmed that the core record is 4 to $6 \mathrm{~m}$ shallower than the logging record, but the correlations are too poor to distinguish between two competing possibilities: (1) the upper $6 \mathrm{~m}$ of the logging record has been clipped or (2) the upper 50 to $100 \mathrm{~m}$ of Holes 704A and 704B has been condensed 

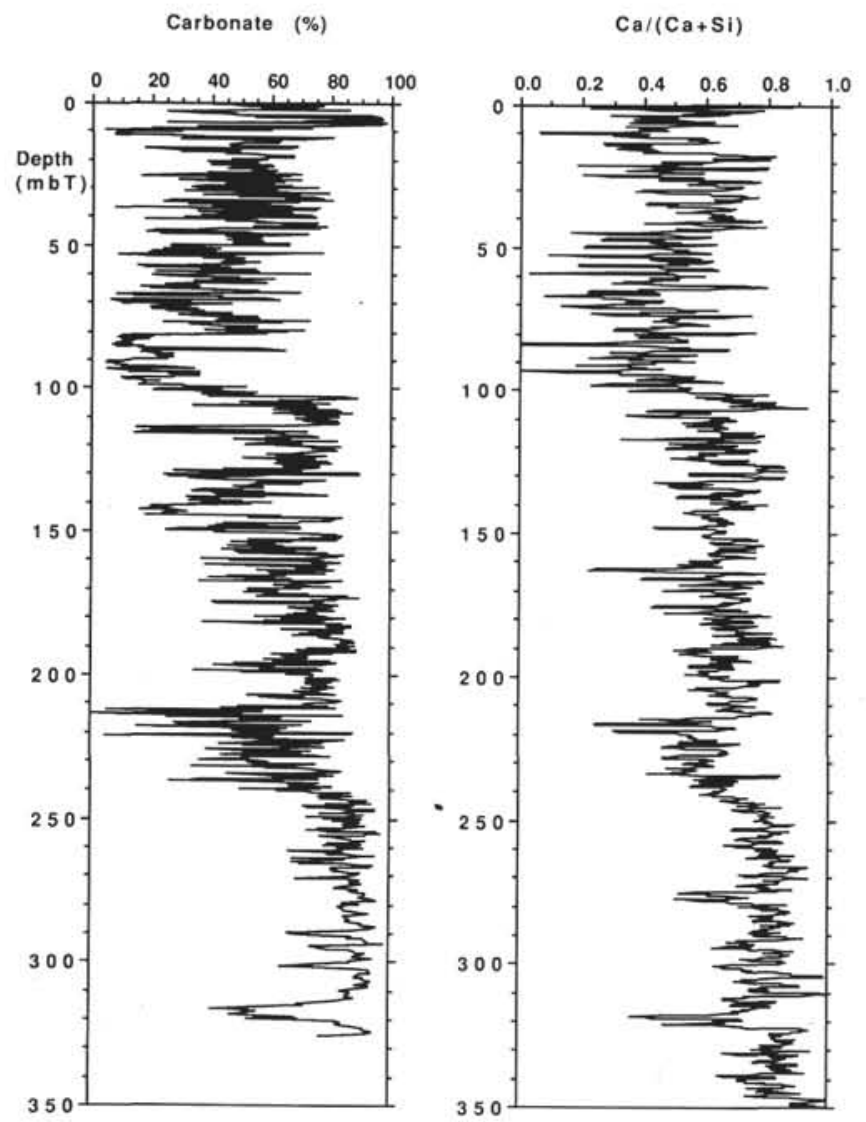

Figure 1. Percent carbonate (composite section) and $\mathrm{Ca} /(\mathrm{Ca}+\mathrm{Si})$ (logging record) plotted vs. depth.

by $6 \mathrm{~m}$ (i.e., a cumulative $6 \mathrm{~m}$ of sediment was lost during coring). Visual inspection of both the cores and the chemostratigraphic records suggests that significant drilling disturbance in this interval is a serious problem even in Hole 704B. This correlation exercise also confirmed that composite depths are offset from logging depths by only 1 to $2 \mathrm{~m}$ throughout the lower portion of the section. Because the composite depth section was generated by adding together the true lengths of cores, we will assume here that the composite depth section is a more accurate estimate of true depths and that the difference between shipboard-reported core depths and logging depths is caused by systematically overestimating the sub-bottom depth of the drill string during coring in high seas.

When the correlation between the carbonate record of the composite section and the logging $\mathrm{Ca} /(\mathrm{Ca}+\mathrm{Si})$ record is limited to the interval between about 100 and $270 \mathrm{mbsf}$, the correlation is fairly good. It is possible to identify almost all of the major peaks and valleys in both records with the exception of the interval including and surrounding Core 114-704A-21X, where recovery was poor. Above $100 \mathrm{mbsf}$, the correlation immediately worsens regardless of the depth intervals compared in both log and composite sections. One problem in the upper $40 \mathrm{~m}$ is drilling or natural disturbance in the core record. Another is the dramatic difference in character of the dominant carbonate minima between 80 and $100 \mathrm{mbT}$, which appear as thick intervals in the coring record but as discrete spikes in the logging record.

Below 270 mbsf, the correlation also worsens. This problem is caused by a prominent doublet carbonate peak at about 275 mbsf in the $\mathrm{Ca} /(\mathrm{Ca}+\mathrm{Si})$ logging record that does not
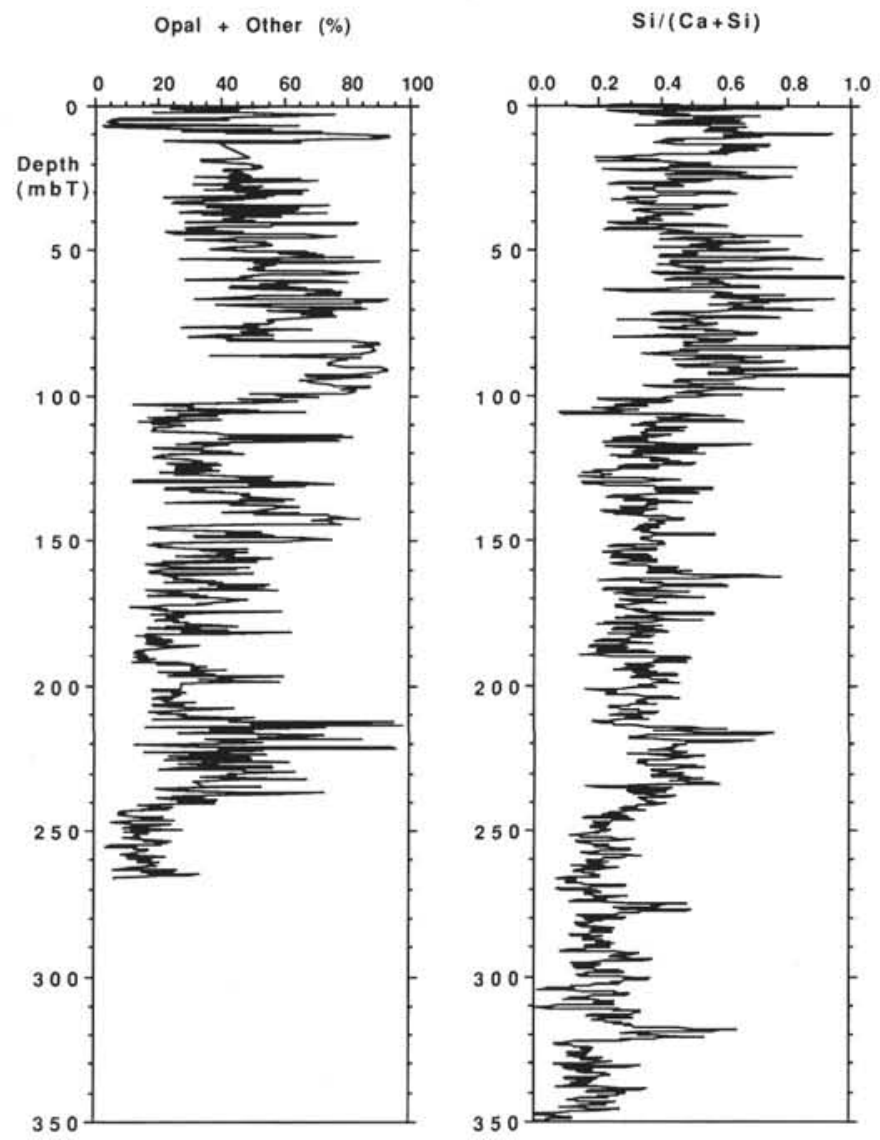

Figure 2. Percent opal + other (composite section) and $\mathrm{Si} /(\mathrm{Ca}+\mathrm{Si})$ (logging record) plotted vs. depth.

appear in the core carbonate record. This interval, about $3 \mathrm{~m}$ long in the logging record, is presumably missing in the core break between Cores 114-704B-30X and 114-704B-31X at $273.4 \mathrm{mbT}$. For this preliminary report, we will ignore this obvious missing interval in the composite section and construct accumulation rates based on the composite section as if it were complete. In the following discussion, we will note how this omission affects our estimates of sedimentation and accumulation rates.

\section{AGES IN SITE 704 COMPOSITE SECTION}

The chronostratigraphic datums selected for age control at Site 704 are presented in Table 3 . We rely primarily on magnetostratigraphy, but use diatom biostratigraphy in intervals with poor paleomagnetic control. The depths of polarity reversals are from Hailwood and Clement (this volume); those for diatom levels are from Fenner (this volume) and Hailwood and Clement (this volume). Because of drilling disturbance and some uncertainty in the interpretation of the placement for the Brunhes/Matuyama boundary and for the top of the Jaramillo, we chose not to employ these datums. The subbottom depths reported for all datums have been converted to depths in the composite section (mbT) via Table 2 . The ages employed are from the geomagnetic polarity time scale of Berggren et al. (1985).

To be consistent with the other papers in this volume, we have adopted the paleomagnetically-assigned boundary for the Matuyama/Gauss boundary (2.47 m.y.) in Hole $704 \mathrm{~A}$ at 167.50-169.95 mbsf (167.49-169.28 mbT) (Hailwood and 
Table 3. Chronology of the Site 704 composite section.

\begin{tabular}{|c|c|c|c|}
\hline Source ${ }^{a}$ & Datum & $\begin{array}{c}\text { Age } \\
\text { (m.y.) }\end{array}$ & $\begin{array}{l}\text { Depth } \\
\text { (mbT) }\end{array}$ \\
\hline D-LAAD & Hemidiscus karstenii & 0.195 & 1.1 \\
\hline D-FAAD & Hemidiscus karstenii & 0.425 & 7.0 \\
\hline D-LAD & Actinocyclus ingens & 0.62 & 18.8 \\
\hline Paleomagnetics & Base Jaramillo & 0.98 & 46.6 \\
\hline Paleomagnetics & Top Olduvai & 1.66 & 88.3 \\
\hline D-LAD & Coscinodiscus kolbei & 1.89 & 101.8 \\
\hline D-LAAD & Coscinodiscus vulnificus & 2.29 & 142.6 \\
\hline Paleomagnetics & Matuyama/Gauss & 2.47 & 168.2 \\
\hline D-LAAD & Nitzschia weaveri & 2.63 & 169.6 \\
\hline Paleomagnetics & Top Kaena & 2.92 & 176.0 \\
\hline Paleomagnetics & Base Kaena & 2.99 & 177.3 \\
\hline Paleomagnetics & Top Mammoth & 3.08 & 178.4 \\
\hline Paleomagnetics & Base Mammoth & 3.18 & 180.6 \\
\hline Paleomagnetics & Gauss/Gilbert & 3.40 & 186.2 \\
\hline Paleomagnetics & Top Cochiti & 3.88 & 195.9 \\
\hline Paleomagnetics & Base Cochiti & 3.97 & 197.7 \\
\hline D-FAD & Nitzschia interfrigidaria & 4.02 & 199.3 \\
\hline Paleomagnetics & Top Nunivak & 4.10 & 200.0 \\
\hline Paleomagnetics & Base Nunivak & 4.24 & 204.7 \\
\hline Paleomagnetics & Top Sidufjall & 4.40 & 206.4 \\
\hline Paleomagnetics & Base Sidufjall & 4.47 & 207.6 \\
\hline Paleomagnetics & Top Thvera & 4.57 & 210.3 \\
\hline Paleomagnetics & Base Thvera & 4.77 & 212.4 \\
\hline Paleomagnetics & Gilbert/C3AN & 5.35 & 217.9 \\
\hline Paleomagnetics & C3AN.33 & 5.53 & 224.4 \\
\hline Paleomagnetics & C3AN.61 & 5.68 & 227.8 \\
\hline Paleomagnetics & C $3 \mathrm{AN} / \mathrm{C} 3 \mathrm{AR}$ & 5.89 & 235.7 \\
\hline Paleomagnetics & C3AR.59 & 6.37 & 242.9 \\
\hline Paleomagnetics & C3AR.75(?) & 6.50 & 248.4 \\
\hline Paleomagnetics & C $3 \mathrm{AR} / \mathrm{C} 4 \mathrm{~N}(?)$ & 6.70 & 251.2 \\
\hline Paleomagnetics & $\mathrm{C} 4 \mathrm{~N} / \mathrm{C} 4 \mathrm{R}$ & 7.41 & 268.0 \\
\hline Paleomagnetics & $\mathrm{C} 4 \mathrm{R} / \mathrm{C} 4 \mathrm{AN}$ & 7.90 & 283.4 \\
\hline Paleomagnetics & C4AN.52 & 8.21 & 313.2 \\
\hline Paleomagnetics & C4AN.85 & 8.41 & 318.8 \\
\hline Paleomagnetics & $\mathrm{C} 4 \mathrm{AN} / \mathrm{C} 4 \mathrm{AR}$ & 8.50 & 321.8 \\
\hline Paleomagnetics & C4AR.50 & 8.71 & 328.3 \\
\hline
\end{tabular}

Note: Paleomagnetic datums are from Hailwood and Clemen (this volume), based on the geomagnetic polarity time scale of Berggren et al. (1985). Diatom datums are from Hailwood and Clement (this volume) and Fenner (this volume). Depth is sub-bottom depth in the composite section (see Table 2).

${ }^{\mathrm{a}} \mathrm{D}-\mathrm{LAAD}=$ diatom last abundant appearance datum; D-LAD = diatom last-appearance datum; D-FAAD = diatom first abundant appearance datum; D-FAD = diatom first-appearance datum.

Clement, this volume). Because this datum controls the timing and magnitude of a dramatic increase in sedimentation and accumulation rates between about 2.6 and $2.0 \mathrm{~m}$.y. (see the following sections), some discussion is warranted. The placement of this datum is well defined paleomagnetically and is consistent with the placement of the last abundant appearance datum (LAAD) of the diatom Cosmiodiscus insignis (2.49 m.y.) at 167.48-169.30 mbsf (167.47-168.63 mbT) (Hailwood and Clement, this volume). One cause for worry is that both of these datums fall in the core break between the bottom of Core 114-704A-18X and the top of Core 114-704A-19X.

Another cause for worry is that this placement of the Matuyama/Gauss boundary is inconsistent with the occurrence of three radiolarian datums. Ling (this volume) placed the last-appearance datums (LADs) of Helotholus vema and Desmospyris spongiosa (both at $2.45 \mathrm{~m} . \mathrm{y}$.) at 148.9-150.3 mbsf (150.0-150.6 mbT), in the core break between Cores 114-704A-16H and 114-704A-17X. J. Hays (pers. comm., 1988) placed these two radiolarian datums slightly higher in the section at 140.2-145.3 mbsf (141.3-146.3 mbT), entirely within Core 114-704A-16H. These two radiolarians are generally good markers for the Matuyama/Gauss boundary (Hays and Opdyke, 1967). In Hole 704A, the occurrence of these
LADs coincides with a weak complex normal polarity interval in the shipboard whole-core cryogenic magnetic data between 144 mbsf in Core 114-704A-16H (145.1 mbT) and $154 \mathrm{mbsf}$ in Core 114-704A-17X (154.3 mbT) (Hailwood and Clement, this volume). However, the interval including the lower part of Core 114-704A-17X and the entire Core 114-704-18X (from 154 to $168.7 \mathrm{mbsf}$ ) is clearly of reversed polarity. This interval contains $H$. vema and $D$. spongiosa, so it is not likely to have been displaced from the overlying Matuyama. In addition, J. Hays (pers. comm., 1988) placed the first-appearance datum (FAD) of Cycladophora davisiana (2.6 m.y.) in the interval 157.6-161.3 mbsf (158.9-161.3 mbT), or near the core break between Cores 114-704A-17X and 114-704A-18X. This FAD always occurs well within the top of the Gauss normal polarity interval in other sections with good paleomagnetic control (Hays et al., in press), but its first appearance in Hole 704A clearly occurs in the middle of the well-defined reversed interval. Hays also recognizes the intact sequence of migrational forms of $C$. davisiana above its FAD in Hole 704A up to $135.5 \mathrm{mbsf}$ (136.3 mbT), suggesting that the section above this datum is not associated with an unconformity or a displaced or disturbed interval in Cores 114-704A-15H, 114-704A-16H, and 114-704A-17X. These three radiolarian datums would then suggest that the Matuyama/Gauss boundary is at the weak reversal near 144 mbsf and that the reversed interval in the lower half of Core 114-704A-17X and the entire Core 114$704 \mathrm{~A}-18 \mathrm{X}$ is somehow problematic. Because this interval in Hole 704B has the same paleomagnetic signature, it is not likely displaced by downhole slumping. It could represent a greatly expanded upper Gauss interval containing the short reversed excursion recognized at Deep Sea Drilling Project (DSDP) Holes 607 and 607A in the North Atlantic (fig. 3 of Raymo et al., 1989).

A third cause for worry is the tentative assignment of the strong glacial isotope stages 96,98 , and 100 , which occur in the lower Matuyama between 2.32 and $2.40 \mathrm{~m}$.y. (Raymo et al., 1989), with the benthic isotope record in Hole 704A between 140 and 148 mbsf (Hodell and Ciesielski, this volume). This would seem to support an argument for placing the Matuyama/Gauss boundary higher in the section, but even this is not consistent with placing the boundary at the weak polarity reversal at 144 mbsf. If this were the boundary, it should coincide with the weak glacial/interglacial stages 104/ 103 (Raymo et al., 1989).

In short, the placement of the Matuyama/Gauss boundary is a problem that is not resolvable with the present information. Thus, we adopt the paleomagnetic boundary placement at 168.7 mbsf as a working hypothesis and admit that the timing of events and the sedimentation and accumulation rates we estimate in the following sections between about 2.6 and $2.2 \mathrm{~m}$.y. could be in error. Regardless of whether one places the Matuyama/Gauss boundary at $144 \mathrm{mbsf}$, at $168.7 \mathrm{mbsf}$, or somewhere in-between, the sedimentation rates for the interval between 2.6 and 2.3 m.y. are very high.

The age vs. depth plot is presented in Figure 3. Sedimentation rates were calculated between each pair of datums and are presented in Table 4. Sedimentation rates on the Meteor Rise were very high above the Gauss, ranging from $140 \mathrm{~m} / \mathrm{Ma}$ at the base of Matuyama to $26 \mathrm{~m} / \mathrm{Ma}$ in the Brunhes. Because of disturbance in the upper $40 \mathrm{~m}$ of the section and likely displacement of biostratigraphic markers, the sedimentation rates estimated for the Brunhes are problematic although it is clear that sedimentation rates must have decreased upward from the base of the Matuyama.

Below the Matuyama/Gauss boundary, sedimentation rates were much lower, ranging from 9 to $42 \mathrm{~m} / \mathrm{Ma}$, with the exception of the top of Chron C4AN (7.9-8.2 m.y.), which 


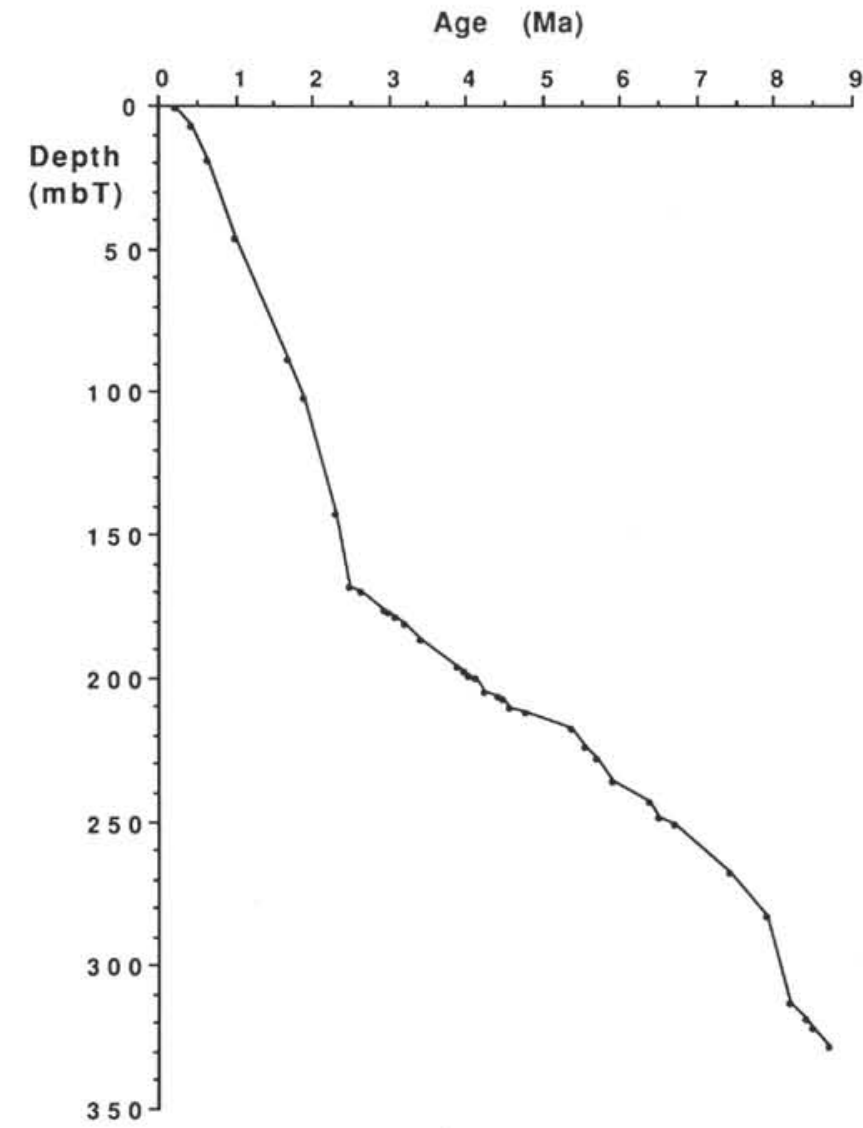

Figure 3. Age plotted vs. sub-bottom depth (mbT) for the Site 704 composite section. Data points represent the datums listed in Table 3.

displays rates of $96 \mathrm{~m} / \mathrm{Ma}$. The previously identified 3-m-long missing section at $273.4 \mathrm{mbT}$, if inserted into the composite section, would increase calculated sedimentation rates for the interval from 268.0 to $283.4 \mathrm{mbT}$ by less than $20 \%$. This interval falls entirely within assigned Chron C4R and would likely not have affected our paleomagnetic interpretation below this point.

The apparent age at the top of Holes 704A and 704B is about $160,000 \mathrm{yr}$, representing at least a 4-m-thick missing section. Piston Core RC13-253 was raised from a depth of $2462 \mathrm{~m}$ on the Meteor Rise about $20 \mathrm{~km}$ from Site 704. Neither the top of this piston core nor that of its trigger core are Holocene, and its bottom $(1076 \mathrm{~cm})$ contains the diatom Actinocyclus ingens, suggesting that the bottom is older that $620,000 \mathrm{yr}$ (L. H. Burckle, pers. comm., 1988). In addition, neither radiolarian biostratigraphy $(C$. davisiana) nor benthic foraminifer oxygen isotope stratigraphy were successful in recognizing a late Quaternary chronology in RC13-253 (J. Hays and N. Shackleton, pers. comm., 1988). Thus, it is likely that this area of the top of the Meteor Rise is simply missing the latest Quaternary.

\section{ACCUMULATION RATES}

\section{Densities}

In order to calculate accumulation rates, it is necessary to have some estimate of dry-bulk densities $\left(B_{D}\right)$, either (1) by measuring dry densities on the same samples from which the chemical data are derived, (2) by measuring wet-bulk density,
Table 4. Sedimentation rates in the Site 704 composite section.

\begin{tabular}{|c|c|c|}
\hline $\begin{array}{l}\text { Depth } \\
\text { interval } \\
(\mathrm{mbT})\end{array}$ & $\begin{array}{c}\text { Age } \\
\text { interval } \\
\text { (m.y.) }\end{array}$ & $\begin{array}{l}\text { Sedimentation } \\
\text { rate }(\mathrm{m} / \mathrm{Ma})\end{array}$ \\
\hline $1.1-7.0$ & $0.195-0.425$ & 25.65 \\
\hline $7.0-18.8$ & $0.425-0.62$ & 60.51 \\
\hline $18.8-46.6$ & $0.62-0.98$ & 77.22 \\
\hline $46.6-88.3$ & $0.98-1.66$ & 61.32 \\
\hline $88.3-101.8$ & $1.66-1.89$ & 58.70 \\
\hline $101.8-142.6$ & $1.89-2.29$ & 102.00 \\
\hline $142.6-168.2$ & $2.29-2.47$ & 142.22 \\
\hline $168.2-169.6$ & $2.47-2.63$ & 8.75 \\
\hline $169.6-176.0$ & $2.63-2.92$ & 22.07 \\
\hline $176.0-177.3$ & $2.92-2.99$ & 21.67 \\
\hline $177.3-178.4$ & $2.99-3.08$ & 12.22 \\
\hline $178.4-180.6$ & $3.08-3.18$ & 22.00 \\
\hline $180.6-186.2$ & $3.18-3.40$ & 25.45 \\
\hline $186.2-195.9$ & $3.40-3.88$ & 20.21 \\
\hline $195.9-197.7$ & $3.88-3.97$ & 20.00 \\
\hline $197.7-199.3$ & $3.97-4.02$ & 32.00 \\
\hline $199.3-200.0$ & $4.02-4.10$ & 8.75 \\
\hline $200.0-204.7$ & $4.10-4.24$ & 33.57 \\
\hline $204.7-206.4$ & $4.24-4.40$ & 10.63 \\
\hline $206.4-207.6$ & $4.40-4.47$ & 17.14 \\
\hline $207.6-210.3$ & $4.47-4.57$ & 27.00 \\
\hline $210.3-212.4$ & $4.47-4.77$ & 10.50 \\
\hline $212.4-217.9$ & $4.77-5.35$ & 9.48 \\
\hline $217.9-224.4$ & $5.35-5.53$ & 38.89 \\
\hline $224.4-227.8$ & $5.53-5.68$ & 22.67 \\
\hline $227.8-235.7$ & $5.68-5.89$ & 37.62 \\
\hline $235.7-242.9$ & $5.89-6.37$ & 15.00 \\
\hline $242.9-248.4$ & $6.37-6.50$ & 42.31 \\
\hline $248.4-251.2$ & $6.50-6.70$ & 14.00 \\
\hline $251.2-268.0$ & $6.70-7.41$ & 23.66 \\
\hline $268.0-283.4$ & $7.41-7.90$ & 31.43 \\
\hline $283.4-313.2$ & $7.90-8.21$ & 96.13 \\
\hline $313.2-318.8$ & $8.21-8.41$ & 28.00 \\
\hline $318.8-321.9$ & $8.41-8.50$ & 33.33 \\
\hline $321.8-328.3$ & $8.50-8.71$ & 30.95 \\
\hline
\end{tabular}

grain density, and porosity on the same samples, (3) by generating an algorithm relating GRAPE-measured density to dry-bulk density and mapping it into the core record, or (4) by generating an algorithm relating dry-bulk densities to some other measured parameter of the same samples, and then applying this function to predict dry densities for all samples. We chose this last approach.

Dry-bulk densities were measured aboard ship for the same samples on which shipboard carbonate data were generated (Ciesielski, Kristoffersen, et al., 1988). These measured drybulk densities are plotted vs. sub-bottom depth in Figure 4A.In the upper $250 \mathrm{~m}$ of Site 704, rhythmic cycles of carbonate and opal deposition impart a parallel cyclicity to densities and other physical properties (Nobes et al., this volume). Carbonate-rich intervals display high densities, whereas opal-rich layers are more porous and less dense. The density structure of the upper $250 \mathrm{~m}$ is thus apparently controlled by this cyclicity plus the effects of lithostatic overburden with increasing sub-bottom depth. We thus tested whether a relationship between dry-bulk density and both carbonate and depth in section was sufficiently precise to use as a predictor of densities for those samples that had carbonate data but no direct measurements of density or porosity.

We found a strong functionality between carbonate content and dry-bulk density that is remarkably independent of depth over two depth ranges: $0-104$ and 104-253 mbT. The depths of 104 and $253 \mathrm{mbT}$ correspond to distinct lithologic boundaries (Ciesielski, Kristoffersen, et al., 1988). We thus broke the record into three segments (0-104, 104-253, and 253-327 mbT) and generated polynomial regressions of carbonate vs. dry-bulk density for each segment (Figs. 4B and 4C). For the 

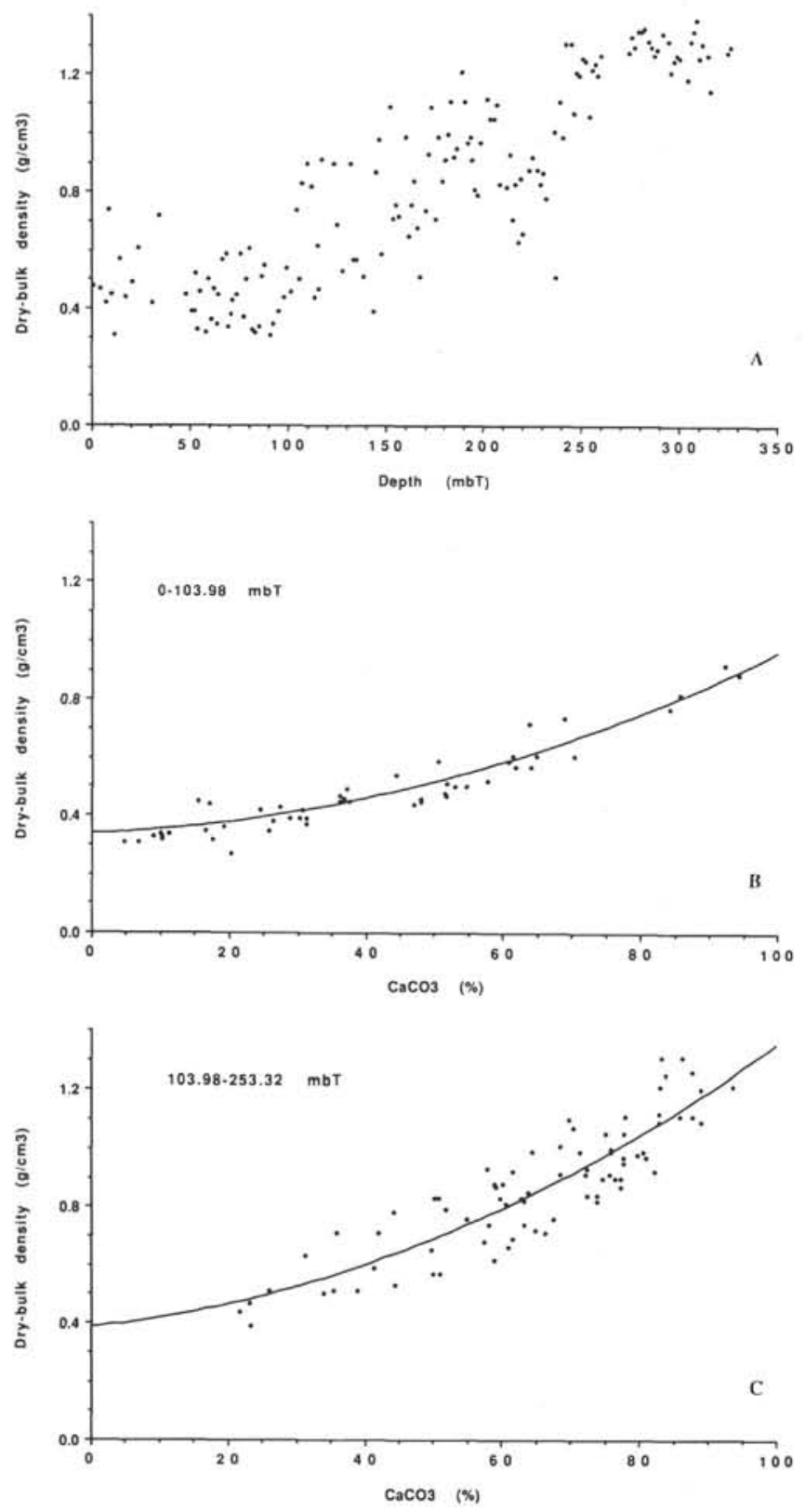

Figure 4. A. Dry-bulk density measured aboard ship plotted vs. composite depth (mbT). B. Measured dry-bulk density plotted vs. shipboard carbonate contents for the depth interval $0-103.98 \mathrm{mbT}$ $(0-102.2 \mathrm{mbsf})$. The line through the data is the best-fit second-order polynomial function predicting dry-bulk density $\left(B_{D}\right)$ from carbonate content: $B_{D}=\left(5.313 \times 10^{-5}\right) \times\left(\mathrm{CaCO}_{3}\right)^{2}+\left(9.346 \times 10^{-4}\right) \times\left(\mathrm{CaCO}_{3}\right)$ $+0.3367 \mathrm{~g} / \mathrm{cm}^{3}, R^{2}=0.85$. C. Measured dry-bulk density plotted vs. shipboard carbonate contents for the depth interval 103.98-253.32 $\mathrm{mbT}(102.2-261.2 \mathrm{mbsf})$. The line through the data is the best-fit second-order polynomial function predicting dry-bulk density from carbonate content: $B_{D}=\left(7.168 \times 10^{-5}\right) \times\left(\mathrm{CaCO}_{3}\right)^{2}+\left(2.474 \times 10^{-3}\right)$ $\times\left(\mathrm{CaCO}_{3}\right)+0.3855 \mathrm{~g} / \mathrm{cm}^{3}, R^{2}=0.79$. Measured dry-bulk densities for the depth interval $253.43-327 \mathrm{mbT}$ are given by the average value (and standard deviation) in this interval, which is used to predict dry-bulk density: $B_{D}=1.27 \pm 0.08 \mathrm{~g} / \mathrm{cm}^{3}$. interval 0-104 mbT, the polynomial function has a high correlation coefficient $\left(R^{2}=0.85\right)$. Inspection of the carbonate vs. dry-bulk density plot (Fig. 4B) suggests that this function is a good predictor of density over this interval. For the interval 104-253 mbT (Fig. 4C), the correlation is slightly lower $\left(R^{2}=0.79\right)$. The correlation is improved only slightly (from $\left(R^{2}=0.79\right.$ to 0.82$)$ by adding the second dependent variable (depth), but this created a complex multivariate functionality that greatly complicated the subsequent computations. We thus chose to use the simple polynomial equation without depth dependence to predict dry-bulk densities for this interval. For the interval between 253 and $327 \mathrm{mbT}$, dry-bulk densities are high and fairly constant with no significant correlation between either density and depth and/or carbonate contents. We thus chose to simply average the densities over this depth range $\left(\mathrm{B}_{\mathrm{D}}=1.27 \pm 0.08 \mathrm{~g} / \mathrm{cm}^{3}\right)$ and to use this value as the predicted density for this interval.

Predicted dry-bulk densities were thus calculated for all samples from the three algorithms presented in the caption of Figure 4. A correlation between predicted dry-bulk densities and measured dry-bulk densities for the same samples (Fig. 5A) demonstrates that (1) there is less than $1 \%$ systematic difference between predicted and measured dry-bulk densities (the predictions are accurate), (2) $94 \%$ of the variation in measured values is accounted for by the predicted values (less than $6 \%$ remains to be explained, for example, by depth), and (3) the average precision of the predictions is about $\pm 15 \%$ (assuming the measured values have no imprecision). Comparison of a plot of predicted dry-bulk densities vs. depth in the composite section (Fig. 5B) with the downhole carbonate plot (Fig. 1) demonstrates a strong similarity, as expected.

\section{Accumulation Rates of Biogenic and Terrigenous Fractions}

Bulk (total) accumulation rates for each sample were calculated by multiplying sedimentation rates (Table 4 ) by the predicted dry-bulk densities for each sample. By using sedimentation rates calculated over short intervals of time (rather than integrating over longer periods), we import errors from both the absolute time scale and from our assigned age model. One error in an assigned datum or age over a small depth interval greatly magnifies the error in apparent sedimentation rates and accumulation rates calculated above and below this point. Thus a more secure procedure might be to integrate accumulation rates over longer intervals. Nevertheless, as our ultimate goal is to produce a high-resolution record of biogenic sedimentation on the Meteor Rise, we will ignore this problem until a high-resolution oxygen isotope-based chronostratigraphy can be constructed. This accumulation rate model will be refined with subsequent improvements in the identification of disturbed, missing, and re-cored intervals in the core records.

Accumulation rates of individual components (carbonate, opal, and terrigenous + other) are computed by multiplying the fraction of each (e.g., \% $\left.\mathrm{CaCO}_{3} / 100\right)$ by the bulk-accumulation rate for each sample, and are reported for each sample in dimensions of $\mathrm{g} / \mathrm{cm}^{2} / 1000 \mathrm{yr}$. The full data set including accumulation rates is not presented here but is available from the senior author upon request.

There are three major uncertainties in our estimates of accumulation rates: age control, "missing" section, and predictions of dry-bulk density. Uncertainties in absolute ages based on the geomagnetic polarity time scale are better than $\pm 2 \%$ for the late Neogene. There is also some additional uncertainty introduced by the assumption of constant sedimentation rates between datums, by potential miscorrelation to the polarity time scale, or by unrecognized missing parts of the sediment record caused by short (unresolvable) hiatuses that can only be tested by comparison to a better age model or 


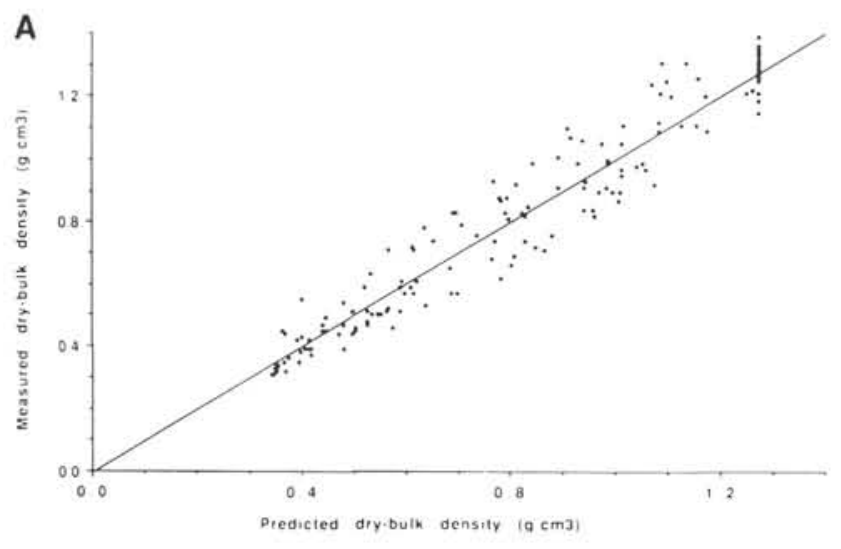

B Predicted dry-bulk density $(\mathrm{g} \mathrm{cm} 3)$

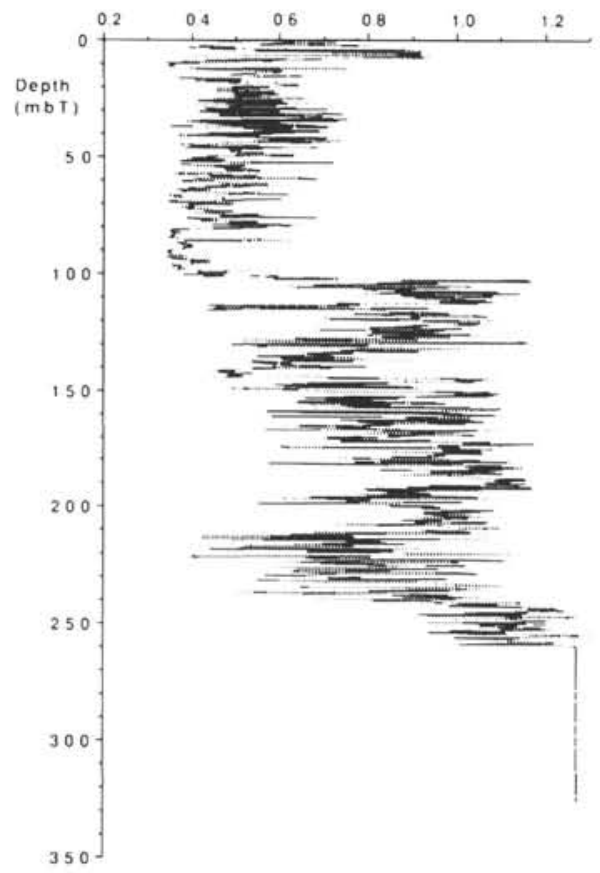

Figure 5. A. Measured (shipboard) dry-bulk density plotted vs. that predicted from carbonate contents (see text). The line through the data is the best-fit linear regression: (measured $B_{D}$ ) $=1.016 \times$ (predicted $B_{D}$ ) $-0.011, R^{2}=0.94$. B. Predicted dry-bulk density plotted vs. depth in the composite section.

to a more complete section nearby. The problem of missing sediment caused by coring problems can be addressed by correlation between the cores of the two holes and the logging records, for which we make only an initial effort here. The uncertainty in our estimates of density (predicted vs. measured) is about $\pm 15 \%$. The sum of all these uncertainties places limits of about $\pm 30 \%$ on the relative reliability of our computed accumulation rates. The accumulation rates calculated for the upper $100 \mathrm{~m}$ are much more uncertain.

\section{RESULTS}

\section{Percent Carbonate, Opal, and Terrigenous Material}

The percent carbonate, opal, and terrigenous data plotted vs. depth in the Site 704 composite section for the last 9 and $2.5 \mathrm{Ma}$ are presented in Figures 6 and 7. The interval containing the Brunhes Chron $(0-0.73 \mathrm{Ma})$ is both disturbed and
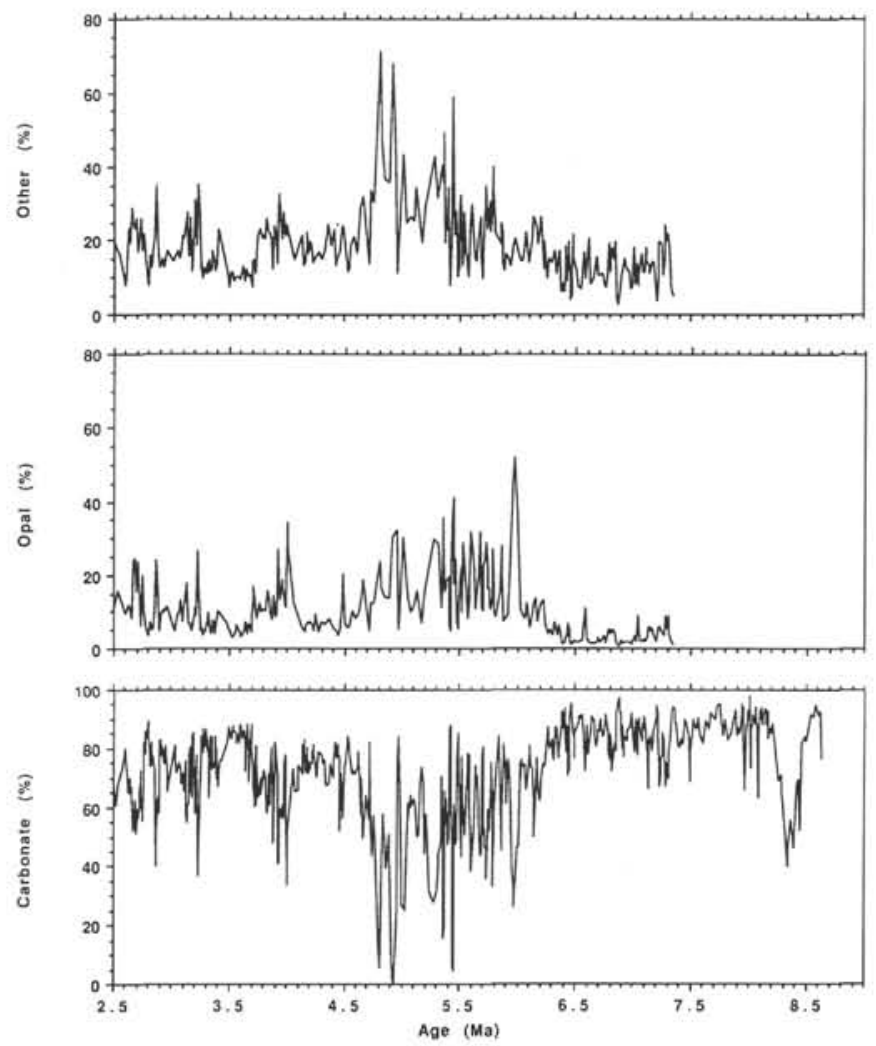

Figure 6. Percent carbonate, opal, and other plotted vs. age for the interval 2.5-9 m.y.

poorly controlled in age and thus will not be discussed here. Prior to the Brunhes/Matuyama boundary, there were significant changes in the nature of sediment deposition on the Meteor Rise. These can be broadly characterized as fluctuations between carbonate and biosiliceous oozes, with pulses of terrigenous dilutants at specific intervals.

Carbonate contents display distinct minima throughout both the composite and logging records of Site 704 (Figs. 1, 6, and 7). In a few of these extrema, carbonate contents drop from $80 \%$ to as low as a few percent. Some carbonate minima coincide with peak opal contents, suggesting that they are more closely related to dilution by opal linked to increases in the overlying biosiliceous productivity. Other minima coincide with maxima in the \%other record, suggesting that they reflect carbonate dissolution horizons in which the terrigenous fraction is enriched. A few of these can be reliably correlated with identified dissolution horizons that have been dated from the Pacific Ocean. We compared our record with sections containing high-resolution carbonate stratigraphy with good age control, including DSDP Holes 157, 158, and 573A and Site 310, piston Cores V24-58, V24-59, V28-179, and RC11209 (Hays et al., 1969; Saito et al., 1975; Dunn and Moore, 1981; Vincent, 1981; Prell, 1985), and the composite eastern equatorial Pacific carbonate records of Dunn (1982). We assigned carbonate terminology to identifiable events according to the mixed nomenclatures of Hays et al. (1969), Vincent (1981), Dunn (1982), and Prell (1985) and used the new age/chron assignments (Berggren et al., 1985) for the carbonate events prior to the Gilbert as correlated in Keller and Barron (1987) and in the appendix of Barron et al. (1985).

After the pronounced carbonate minimum at 8.5-8.2 m.y. (for which we have no opal or other data), the interval from 8.2 to $6.3 \mathrm{~m} . \mathrm{y}$. is characterized by uniformly high carbonate 

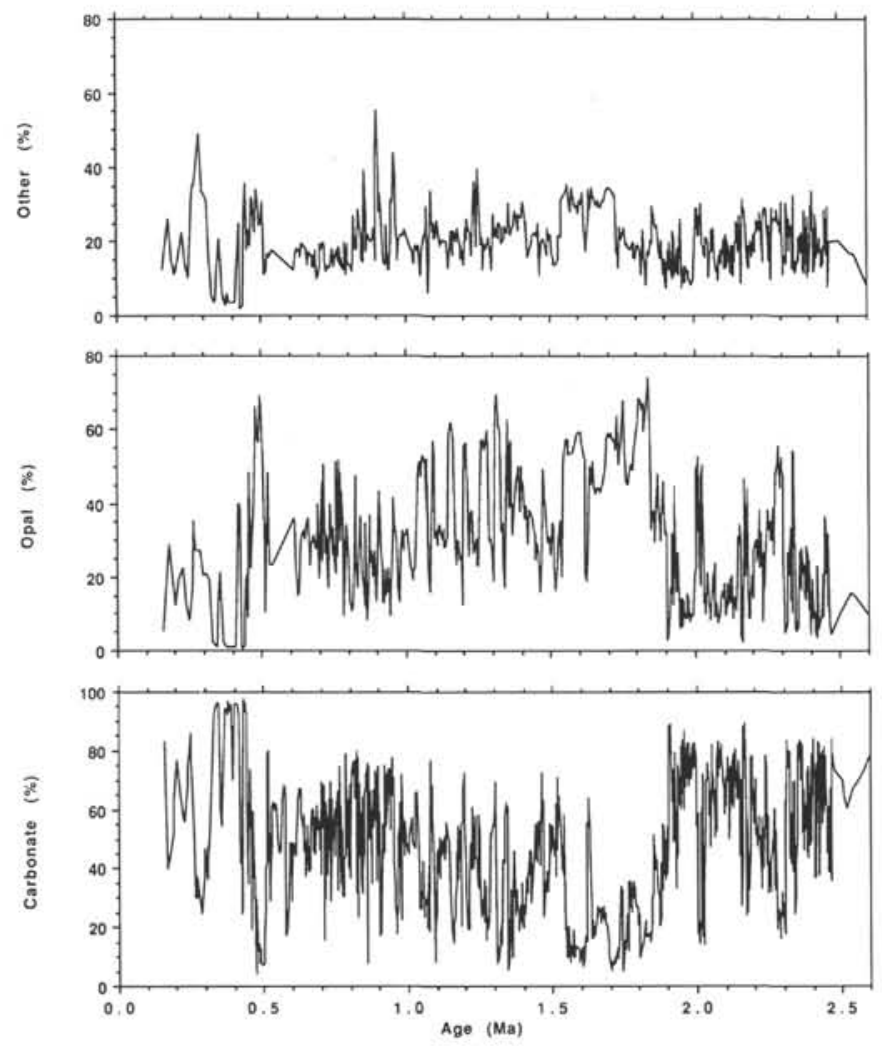

Figure 7. Percent carbonate, opal, and other plotted vs. age for the interval $0-2.5 \mathrm{~m} . \mathrm{y}$.

contents $(80 \%-90 \%)$, low opal contents $(<5 \%)$, and low terrigenous contents $(<15 \%)$. This period is punctuated by distinct doublet carbonate minima, which occur at about 7.5-7.6 m.y. (visible in the $\mathrm{Ca} /(\mathrm{Ca}+\mathrm{Si})$ logging record at about 275 mbsf in Fig. 1 but missing in the core record). Beginning about 6.2 m.y. ago, carbonate displays a small step decrease and begins cyclical fluctuations that dramatically increase in amplitude until about $4.8 \mathrm{~m} . \mathrm{y}$. Also at $6.2 \mathrm{~m} . \mathrm{y}$., opal and other both display a small step increase, but dramatic cyclicity does not begin until the strong carbonate minimum just after $6.0 \mathrm{~m}$.y. Since this carbonate minimum is associated with a strong opal maximum $(50 \%)$ and does not coincide with a terrigenous maximum, it most likely reflects an increase in biogenic opal supply to the sediment at $6.0 \mathrm{~m}$.y.

From 6.0 to $4.8 \mathrm{~m} . y$., carbonate fluctuations increase in amplitude, paralleling increases in the amplitude of terrigenous fluctuations but decreases in the amplitude of opal variations, culminating in the 4.8 and $4.9 \mathrm{~m}$.y. events characterized by intervals of very low carbonate $(<5 \%)$ and very high terrigenous $(>70 \%)$ contents. Thus it appears that there was a dramatic increase in opal productivity over the Meteor Rise at $6.0 \mathrm{~m} . \mathrm{y}$. that heralded strong fluctuations in opal deposition that decreased in amplitude over the next 1 to 1.5 m.y. This coincided with a period of increasing strength of periodic carbonate dissolution events. We tentatively correlate these carbonate minima with carbonate dissolution events Gi17 through Gi19, dominant carbonate minima visible in most Pacific sections containing this interval (Vincent, 1981). These minima occur in other carbonate records as multiple poorly-resolved troughs near the base of the Gilbert Chron. Keller and Barron (1987) correlate these events with hiatus NH7, which occurred between about 5.2 and 4.7 m.y. At Site 704 , the minima appear as a triplet in the logging record but as a sextuplet in the core carbonate record between 212 and 222 mbT (Fig. 1). The ages of these six minima, assuming constant sedimentation rates between datums (Table 3 ), work out to $4.81,4.93,5.02,5.29,5.37$, and 5.45 m.y., spanning the interval from just below the top of Chron $\mathrm{C} 3 \mathrm{AN}$ up into the Gilbert to the base of the Thvera Subchron, where carbonate minima abruptly terminate. Müller et al. (this volume) and Hodell and Ciesielski (this volume) suggest that this interval of carbonate dissolution events corresponds to latter stages of Messinian evaporite deposition in the Mediterranean, which also ended abruptly at about the same time (Müller and Hsü, 1987).

From 4.8 to 4.5 m.y., carbonate contents increase and opal and terrigenous contents decrease, approaching their values from during the period prior to $6.3 \mathrm{~m}$.y. From 4.5 to $2.5 \mathrm{~m}$.y., carbonate contents are again uniformly high, with three minor intervals of midrange carbonate lows associated with opal and terrigenous maxima at about 4.0-3.9, 3.2, and 2.9 m.y.

Beginning at 2.47 m.y., opal and carbonate contents begin a series of intense cyclic fluctuations with amplitudes of $20 \%-80 \% \mathrm{CaCO}_{3}$ and $50 \%-10 \%$ opal (Fig. 7). From 2.47 to 1.9 m.y., these cycles are strong, with major opal peaks mirroring carbonate minima at $2.34,2.29,2.18$, and $2.00-2.03 \mathrm{~m}$.y. This cyclicity is only vaguely reflected in fluctuations of the terrigenous component and is thus most likely related to alternating deposition of carbonate and opal. This pattern reflects dilution of carbonate by opal (and vice versa) caused by alternating periods of carbonate-rich and opal-rich production in the overlying waters. In the logging $\mathrm{Ca} /(\mathrm{Ca}+\mathrm{Si})$ record, there is a strong carbonate minimum at 163 mbsf that is only weakly present as multiple minima in the core carbonate record at 165 to $167 \mathrm{mbT}$ ( $2.45 \mathrm{~m} . \mathrm{y}$.). We tentatively correlate this minimum with carbonate event Ma21, which is a dominant feature of Pacific carbonate records and occurs near $2.4 \mathrm{~m}$.y. at the base of the Matuyama, just above the top of the Gauss (Vincent, 1981), although it is clear that this is not necessarily a dissolution event in the Site 704 record. Event Ma21 coincides with strong maximum (enriched) ${ }^{18} \mathrm{O}$ benthic foraminiferal peaks in the isotopic records of Vincent (1981) and at Site 704 (Hodell and Ciesielski, this volume), demonstrating "Atlantictype" carbonate stratigraphy wherein carbonate minima coincide with glacial intervals.

The interval from 2.00 to $1.84 \mathrm{~m} . \mathrm{y}$. is characterized by low-amplitude cyclic fluctuations with steadily decreasing carbonate and increasing opal contents, culminating in a peak opal concentration of over $70 \%$ at $1.84 \mathrm{~m}$.y. From 1.84 to about $1.54 \mathrm{~m}$.y., carbonate contents are generally low $(<30 \%)$ and opal high $(>50 \%)$. This interval also contains two pronounced and adjacent steplike peaks where the terrigenous fraction approaches $30 \%$. These features are associated with the long periods of carbonate lows and thus may reflect dissolution. This pattern occurs in the core record between 84 and 104 mbT (Figs. 1 and 2) as three separate 4- to 5-m-thick beds of carbonate-poor, opal-rich sediment, with a short burst of carbonate-rich sediment at $1.63 \mathrm{~m} . \mathrm{y}$., where carbonate contents approach $60 \%$. The logging records for this $1.84-1.54$ m.y. interval (about 80 to 100 mbsf in Figs. 1 and 2) display a dramatically different character, containing only two short $(<1 \mathrm{~m})$ intervals of carbonate-poor, silica-rich sediment. We suspect that the core record is contaminated by disturbance throughout this interval in Cores 114-704A-10H and 114$704 \mathrm{~A}-11 \mathrm{H}$ but withhold judgment until analyses of Hole 704B are completed. We tentatively correlate these $\mathrm{Ca} /(\mathrm{Ca}+\mathrm{Si})$ minima in the logging record as event $\mathrm{Ma17}$, a carbonate minimum occurring within the Olduvai Subchron (Vincent, 1981; Hays et al., 1969; Dunn, 1982). This event is visible in both the core and logging records as a series of minima with a 
strong doublet component occurring in the coring record across the top of the Olduvai, between 1.6 and $1.7 \mathrm{Ma}$. While the core record appears disturbed in this interval, these minima also appear to correspond to periods of glaciation $\left({ }^{18} \mathrm{O}\right.$ maxima in the isotopic records of Vincent, 1981, and Hodell and Ciesielski, this volume).

At 1.54 m.y., sharp increases in carbonate and decreases in opal coincide with the reinitiation of alternating rhythmic fluctuations that continue up into the Brunhes. The interval centered on about $0.9 \mathrm{~m} . \mathrm{y}$. contains a series of at least three distinct peaks in terrigenous material, also associated with mirror-image carbonate minima.

\section{Accumulation Rates of Carbonate, Opal, and Terrigenous Material}

Deposition on the Meteor Rise is dominated by dramatic changes in sedimentation rates that are forced by the age model (Fig. 3 and Tables 3 and 4). The largest of these occurs near the Matuyama/Gauss boundary $(2.47 \mathrm{~m} . \mathrm{y}$.) where sedimentation rates increase sixfold, from 20 to over $120 \mathrm{~m} / \mathrm{Ma}$. This change is significant because ages are well-constrained above and below this level and because it heralds a major paleoceanographic change: the onset of glaciation in the Northern Hemisphere (Shackleton et al., 1984). This event was apparently accompanied by a dramatic increase in terrigenous and biogenic sedimentation on the Meteor Rise. The decreases in sedimentation rates upsection at $2.29 \mathrm{~m} . \mathrm{y}$. (from 140 to $100 \mathrm{~m} / \mathrm{Ma}$ ) and at $1.89 \mathrm{~m} . \mathrm{y}$. (from 100 to $60 \mathrm{~m} / \mathrm{Ma}$ ) are less well-constrained in age because they are dependent upon the placement of datums for the diatoms Coscinodiscus vulnificus and Coscinodiscus kolbei. Without these two datums the shifts in sedimentation rates could have occurred anywhere between the top of the Olduvai $(1.66 \mathrm{~m} . \mathrm{y}$.) and the Gauss/Matuyama boundary (2.47 m.y.). We will thus refer to this interval as the "about 2 m.y." sedimentation rate decrease because it seems most likely to have occurred sometime between 1.9 and 2.3 m.y.

Changes in sedimentation below the top of the Gauss are based on detailed paleomagnetic boundaries that are generally well correlated to the geomagnetic polarity time scale down to $268.0 \mathrm{mbT}$ (C4N/C4R boundary at $7.41 \mathrm{~m} . \mathrm{y}$.). Short intervals with apparently low sedimentation rates (compared to their upper or lower companion intervals) could be the result of short hiatuses in the sediment record (for example, at 169 and $200 \mathrm{mbT}$ ). Alternatively, the high sedimentation rate interval during Chron C4AN (7.90 to $8.21 \mathrm{~m} . \mathrm{y}$. between 283.4 and $313.2 \mathrm{mbT} ; 96 \mathrm{~m} / \mathrm{Ma}$ ) may be the result of sediment disturbance. Hailwood and Clement (this volume) consider downslope slumping from the topographic highs surrounding Site 704 as a potential explanation for the complex series of polarity reversals they observe during Chron $\mathrm{C} 4 \mathrm{AN}$, possibly contributing to repetition and thus lengthening of this interval. If this interpretation is correct, the sedimentation rates estimated for this interval are artificially too high.

Accumulation rates for the last 9 and $2.5 \mathrm{Ma}$ are presented in Figures 8 and 9. From 8.5 to $2.5 \mathrm{~m}$.y., bulk-accumulation rates are low, ranging from 0.5 to about $5 \mathrm{~g} / \mathrm{cm}^{2} / 1000 \mathrm{yr}$ and averaging less than $2 \mathrm{~g} / \mathrm{cm}^{2} / 1000 \mathrm{yr}$ (ignoring the high sedimentation rate interval of Chron C4AN). From 7.8 to 6.5 m.y., there is a gradual decrease in bulk-accumulation rates dominated by decreasing carbonate accumulation rates. Terrigenous and opal accumulation rates are very low and also decreasing. Between 6.5 and $6.4 \mathrm{~m} . \mathrm{y}$., there is a period of relatively high carbonate accumulation (up to $5 \mathrm{~g} / \mathrm{cm}^{2} / 1000 \mathrm{yr}$ ) accompanied by a pronounced increase in terrigenous accumulation but very little increase in opal accumulation rates. From 6.4 to 6.0 m.y., bulk-accumulation rates are again very low and decreasing, driven by decreases in carbonate accumulation rates with little change in either terrigenous or opal accumulation. Between 6.0 and 5.9 m.y., there is a significant increase in opal accumulation accompanied by a decrease in bulk, carbonate, and terrigenous accumulation rates, coinciding with the peak opal abundance in Figure 6 . This is followed at $5.9 \mathrm{~m} . \mathrm{y}$. by increased bulk, terrigenous, and carbonate accumulation rates. From 5.9 to about 5.4 m.y., all components of accumulation are moderately high, with alternating carbonate and opal cyclicity driving fluctuations in bulkaccumulation rates. During this period, there are two pronounced peaks in the accumulation rates of the terrigenous component, centered on about 5.8 and 5.4 m.y. From 5.4 to 4.6 m.y., bulk-accumulation rates are again very low $(<1$ $\mathrm{g} / \mathrm{cm}^{2} / 1000 \mathrm{yr}$ ). During this period of dramatic cyclicity in carbonate contents (less so in opal contents; Fig. 6), terrigenous accumulation rates are fairly constant, suggesting that the fluctuations in carbonate content are not caused by enhanced terrigenous input (dilution) but rather by carbonate dissolution. From 4.6 to 4.4 m.y., there is a minor increase in bulk and carbonate accumulations that is only weakly mirrored in opal and terrigenous accumulation rates. Between 4.4 and 4.24 m.y., accumulation rates of all components are again very low. At 4.24 m.y., bulk-accumulation rates increase, accompanied by marked increases in carbonate and terrigenous accumulation but little increase in opal accumulation rates, which continues until $4.1 \mathrm{~m}$.y. Between 4.1 and 4.02 m.y. there are very low accumulation rates in all components (hiatus?). Just after $4.0 \mathrm{~m} . \mathrm{y}$., there is a short pulse of relatively high bulk accumulation accompanied by enhanced opal and terrigenous accumulation rates, suggesting that the carbonate minima in this interval (Fig. 6) are due to dilution rather than dissolution. From 3.9 to $2.6 \mathrm{~m}$.y., bulk-accumulation rates are moderately low $\left(\sim 2 \mathrm{~g} / \mathrm{cm}^{2} / 1000 \mathrm{yr}\right)$, dominated by carbonate accumulation with fairly low opal and terrigenous accumulation rates. The carbonate content minima at 3.2 and 2.9 m.y. (Fig. 6) appear to coincide with periods of increased opal and terrigenous accumulation rates and are thus also likely due to dilution rather than dissolution. From 2.6 to 2.47 m.y., accumulation rates of all components appear to be very low (hiatus?).

At $2.47 \mathrm{~m} . \mathrm{y}$., there is a dramatic increase in the accumulation of all components (Fig. 9) coincident with an increase in the amplitude of high-frequency fluctuations in carbonate and opal contents (Fig. 7). The high-frequency variations in accumulation rates are more apparent than real due to the way in which accumulation rates were calculated. Without age control at the same resolution as the fluctuations it is impossible to determine whether carbonate-rich intervals accumulate faster than opal-rich intervals, as is suggested by close examination of Figure 9. While bulk accumulation increases at 2.47 m.y. an average of about sixfold (parallel to the increase in sedimentation rates), the increase in peak opal accumulation rates is relatively greater, at least tenfold. This reflects an increased abundance of biosiliceous components in the cyclic carbonate fluctuations. Terrigenous accumulation reaches peak rates of 2 to $3 \mathrm{~g} / \mathrm{cm}^{2} / 1000 \mathrm{yr}$ between 2.47 and $2.4 \mathrm{~m}$.y., declining fairly regularly to rates less than $0.5 \mathrm{~g} / \mathrm{cm}^{2} / 1000 \mathrm{yr}$ by $1.9 \mathrm{~m} . \mathrm{y}$. The gradual nature of this decrease in terrigenous accumulation rates suggests that the age model for this interval (dependent upon datums at 2.29 and 1.89 m.y.) adequately describes the "about 2 m.y." decrease in sedimentation rates.

The nature of carbonate and opal deposition during this interval from 2.47 to 1.89 m.y. is quite different from that of terrigenous material. From 2.47 to 2.29 m.y., peak carbonate and opal accumulation rates approach 13 and $4 \mathrm{~g} / \mathrm{cm}^{2} / 1000 \mathrm{yr}$, respectively, reflecting high overlying biogenic production. 

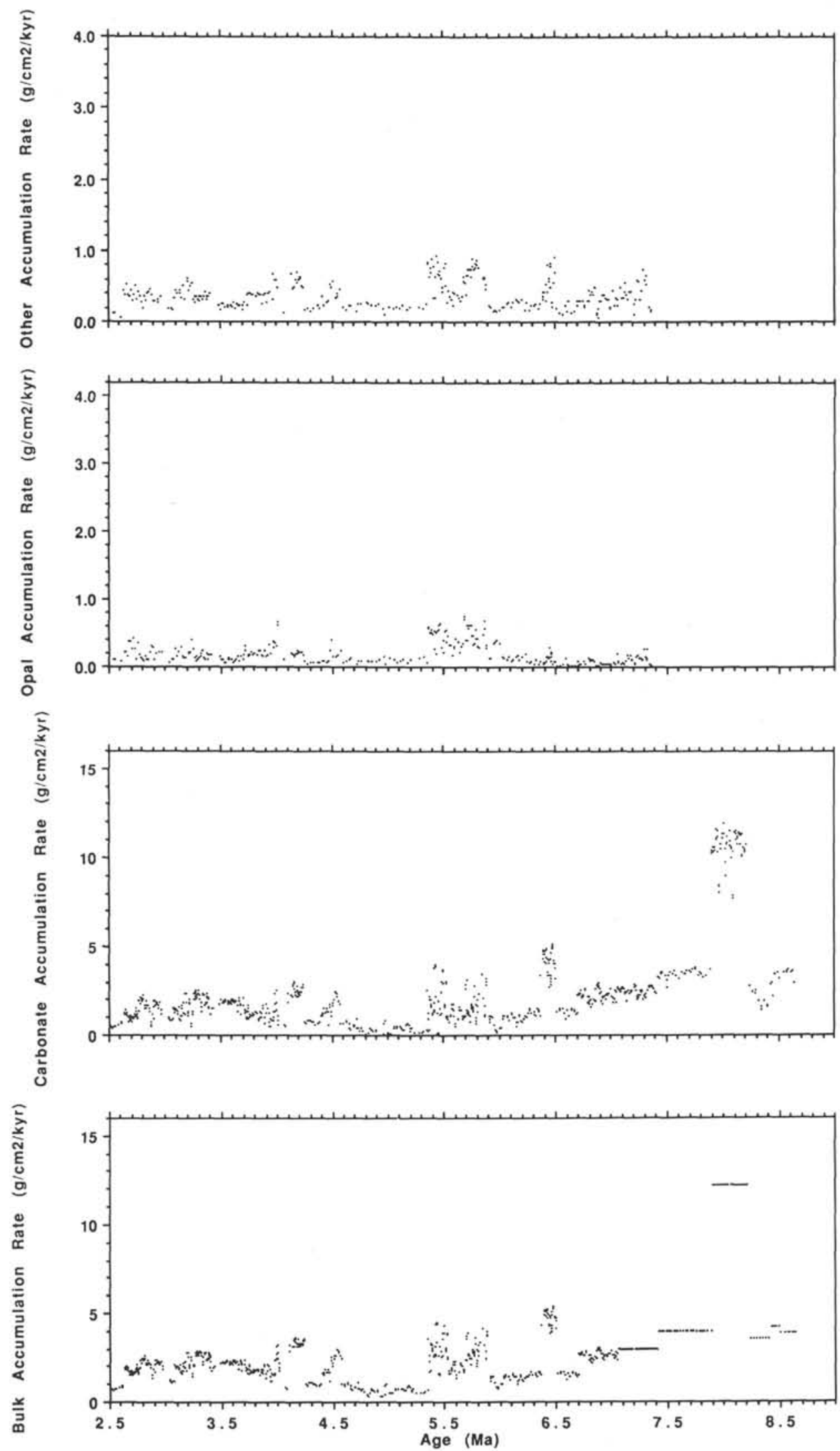

Figure 8. Accumulation rates of bulk (total), carbonate, opal, and other plotted vs. age for the interval 2.5-9 m.y. 

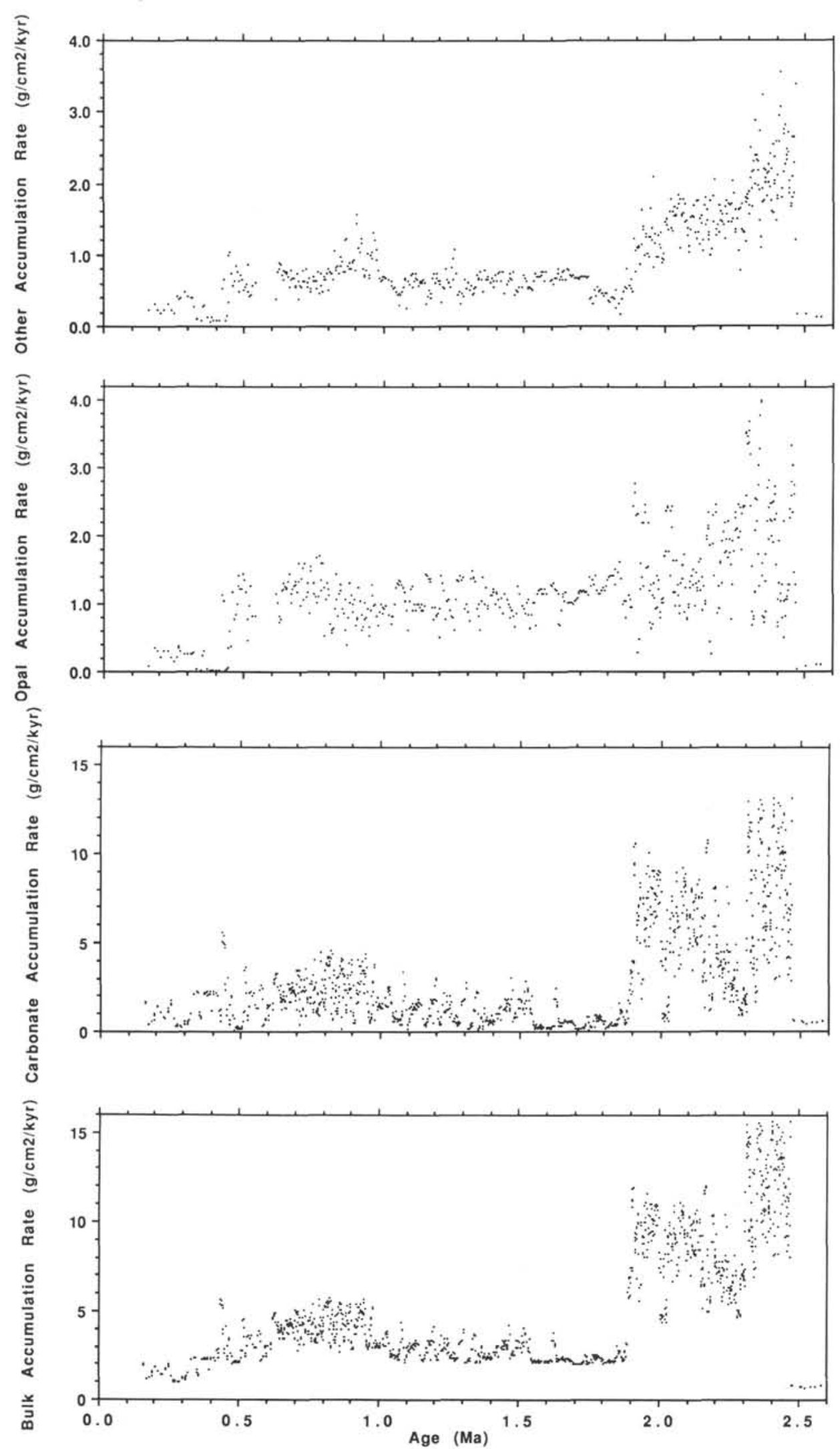

Figure 9. Accumulation rates of bulk (total), carbonate, opal, and other plotted vs. age for the interval 0-2.5 m.y. 
Highest opal accumulation occurs at 2.34 and 2.29 m.y. Just after 2.29 m.y., bulk and carbonate peak accumulations drop dramatically to about one-third and one-sixth, respectively, of their prior rates, while peak opal accumulation decreases by only about $40 \%$. From 2.29 to 1.89 m.y., peak bulk and carbonate accumulation rates increase while peak opal accumulation decreases, punctuated by short high-opal and lowcarbonate accumulation intervals at about 2.18 and $2.00-2.03$ m.y. At about 1.9 m.y., there are two short bursts of high-opal and then high-carbonate deposition, followed immediately at 1.89 m.y. by dramatic decreases in bulk, carbonate, and terrigenous accumulation but only a slight decrease in opal accumulation rates. Whereas the timing and relative magnitudes of these changes are dependent upon two datums (the "about 2 m.y." sedimentation rate decrease), there appears little doubt that between about 2.3 and 1.9 m.y. there was an increase in bulk, carbonate, and terrigenous deposition on the Meteor Rise that was accompanied by a slight decrease in opal accumulation. It is also clear that there must have been a tenfold decrease in carbonate accumulation from 2.47 to 1.66 m.y. that was accompanied by only a twofold decrease in opal accumulation.

From 1.84 to about $1.54 \mathrm{~m} . y$. , carbonate accumulation is low, and the bulk of the deposition is composed of opal and terrigenous fractions. As discussed previously, this interval may have been disturbed in the core record so it is unclear whether this entire period was in fact one of fairly high and continuous opal deposition. From 1.54 to about 1.0 m.y., deposition was dominated by alternating carbonate and opal fluctuations (Fig. 7) with about the same average opal accumulation rates as the previous 0.3 Ma but perhaps slightly higher bulk, carbonate, and terrigenous accumulation.

\section{DISCUSSION}

A full discussion of the high-resolution paleoclimatic implications of these records will be postponed until after the two holes at Site 704 have been successfully spliced together and the extent of drilling disturbance and missing or re-cored section has been verified by detailed correlation of this new composite record with the final processed logging data. We will also postpone discussion of the long-term changes in terrigenous accumulation rates (except for recognition of carbonate dissolution intervals) until the sources of this material can be established. Thus in the following discussion we will interpret changes in the biogenic accumulation rates over periods of time longer than that ultmately resolvable from Site 704 .

To simplify the following discussion, we have produced a generalized view of the long-term changes in biogenic deposition at Site 704 (Fig. 10). In this figure, biogenic accumulation rates (BAR) are defined as the sum of carbonate plus opal accumulation rates. We take this as a measure of the general level of primary production in overlying surface waters (ignoring carbonate dissolution for the moment) (Fig. 10A). The ratio of opal to total biogenic accumulation we will take as a proxy indicator of upwelling diversity (again ignoring carbonate dissolution), which we term a Polar Front Indicator (PFI) (Fig. 10B). When the Polar Front Zone is far south of Site 704 (or when calcareous production dominates the southern oceans), carbonate oozes accumulate on the Meteor Rise and the PFI has a low value. When the Polar Front is farther north, near or over Site 704 (or when biosiliceous production dominates the Southern Oceans), biosiliceous oozes dominate deposition and the PFI has a high value. Because we can not distinguish changes in relative composition of productivity from shifts in location of the production gradient with data from only one site, we will tentatively take changes in this PFI to reflect relative northward or southward migration of the PFZ's opal-rich belt.

Note that the data plotted in Figure 10 were averaged with a nine-point running mean so that they represent crude filtering over intervals of about $50,000 \mathrm{yr}(0-2.47$ m.y.) and 200,000 yr (2.47-7.32 m.y.). Therefore, we will consider long-term migrations of the PFZ not exceeding $30,000 \mathrm{yr}$ $(0-2.5$ m.y.) and $100,000 \mathrm{yr}(2.5-6.4$ m.y.). We will interpret Figures $10 \mathrm{~A}$ and $10 \mathrm{~B}$ within the following set of guidelines:

1. When BAR and PFI are both increasing, no information about PFZ migration is possible because both indicators may be marking only a general increase in biosiliceous production in the Southern Ocean.

2. When BAR is increasing (or remaining about constant) and PFI is decreasing, the PFZ is likely migrating southward away from Site 704.

3. When BAR is decreasing (or remaining about constant) and PFI is increasing, the PFZ is likely migrating northward toward Site 704.

4. When BAR and PFI are both decreasing, no information about PFZ migration is possible because both indicators may be marking only a general decrease in biosiliceous production in the Southern Ocean.

5. When both BAR and PFI are remaining about constant, it is likely that the PFZ is stationary.

6. During periods of intense carbonate dissolution, neither record has any reasonable paleoproductivity information.

With these "rules" and limitations in mind, a sequence of plausible PFZ migrations can be extracted from inspection of Figure 10. In most cases of strong PFZ migration, rules 2 or 3 apply, suggesting that climatic deterioration (PFZ migration northward) is accompanied by decreasing biogenic accumulation on the Meteor Rise. We will show that northward (southward) migrations inferred from the PFI generally coincide with times of known climatic cooling (warming) in the Northern and/or Southern hemispheres and that the apparent magnitude of these frontal migrations generally agrees with the intensity of these climatic changes.

6.4-6.1 m.y.: PFZ barely migrating northward from a far southerly position (rule 3 , but could be influenced by rule 6 ); very weak cooling(?) in the warm period of the late Miocene (top of Chron C3AR). This period coincides with decreasing $\delta^{18} \mathrm{O}$ considered to reflect warm, interglacial conditions and the beginning of a decrease in planktonic and benthic $\delta^{13} \mathrm{C}$ that is associated with the Chron $6(\mathrm{C} 3 \mathrm{AN})$ global "carbon shift" linked to reorganization of deep oceanic nutrient circulation (Hodell and Ciesielski, this volume). Because diatom and silicoflagellate assemblages in Hole 704A indicate periods of low productivity and warm, low salinities coincident with brief $\delta^{18} \mathrm{O}$ minima (Müller et al., this volume) and poor foraminifer preservation between 6.4 and $4.8 \mathrm{~m}$.y. (Brunner, this volume), the PFI may be not accurately reflecting Polar Front migration and weak cooling, but rather some combination of enriched nutrients in the Southern Ocean (higher biosiliceous productivity) at a time of very warm climate and moderate carbonate dissolution. The end of this period (at about 6.15 m.y.) coincides with the laminated organic-rich Neobrunia ooze containing a subtropical to tropical siliceous microfossil assemblage at Site 701 (discussed in Müller et al., this volume), suggesting very warm surface waters and an almost stagnant deep-water circulation.

6.1-6.0 m.y.: PFZ migrating northward (rule 3); moderate cooling in the late Miocene. This interval coincides with a sharp increase in $\delta^{18} \mathrm{O}$ in Hole 704A (cooling and/or glacial re-advance) (Müller et al., this volume) and the beginning of a period of intense upwelling coincident with the first opal peak at about $6.0 \mathrm{~m}$.y. (Fenner, this volume). Because this opal 

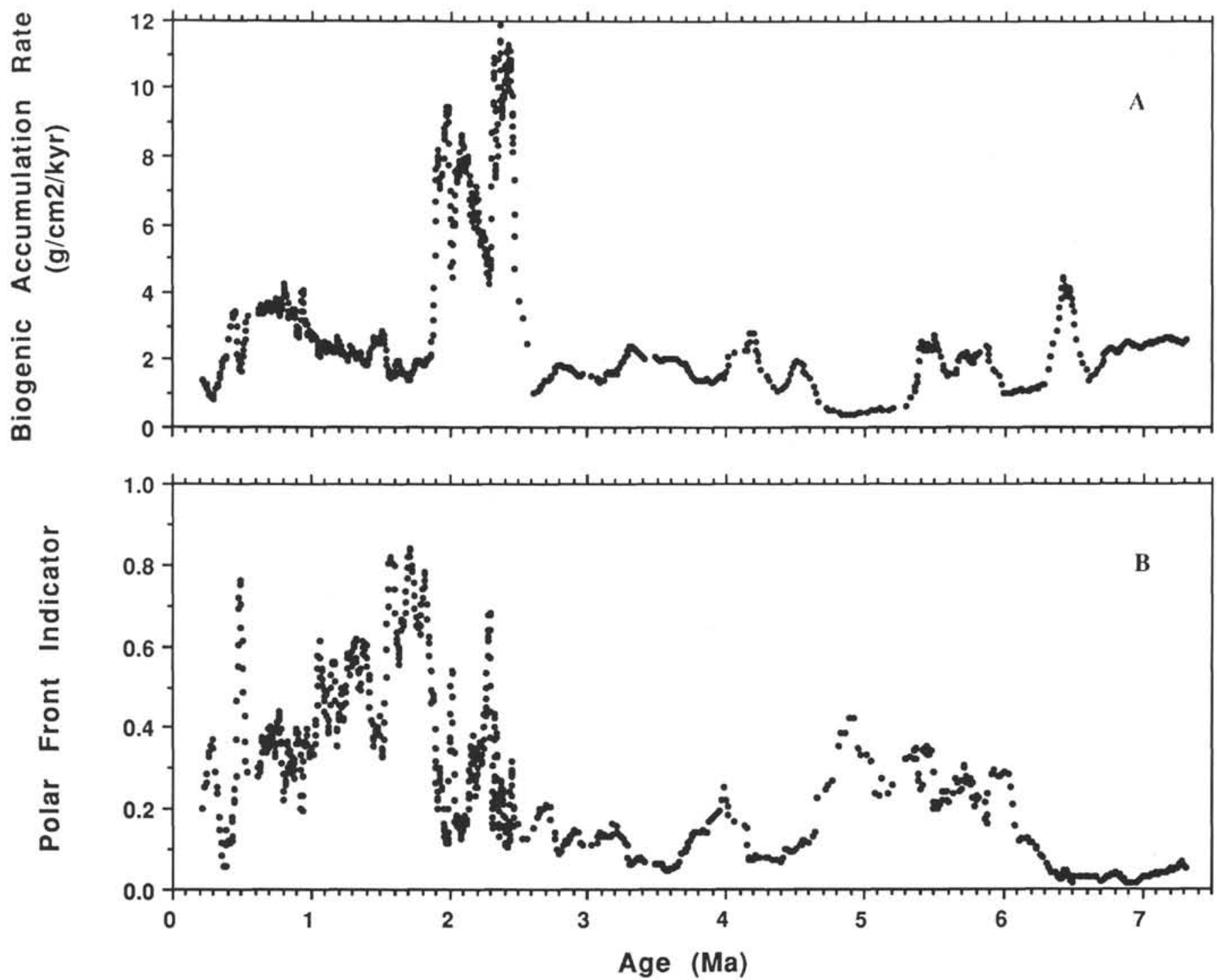

Figure 10. A. Biogenic accumulation rates plotted vs. age. Biogenic accumulation is the sum of the carbonate plus opal accumulation rates. The data plotted here were smoothed with a nine-point running mean. B. A Polar Front Indicator (proxy of upwelling diversity) plotted vs. age. This indicator is the ratio of opal accumulation to opal plus carbonate accumulation, so that a value of one indicates pure opal deposition and a value of zero indicates pure carbonate deposition. High values are interpreted to reflect proximate location (and low values remote) of the PFZ with respect to Site 704. Other interpretations are possible (see text). This record was smoothed with a nine-point running mean.

peak is not associated with a carbonate dissolution event (see previous discussions of this peak), it likely marks the first significant approach of the PFZ toward Site 704. This interval also coincides with the first occurrence of traces of ice-rafted debris in the southern South Atlantic at about 6 m.y. (Bornhold, 1983) and just above the hiatus at Site 699 (about 6.4-6.0 m.y.; Allen and Warnke, this volume).

6.0-5.5 m.y.: PFZ stationary (with oscillations) at more northerly position (rules 3 and 5 , but could be influenced by rule 6); late Miocene cool period (Chron C3AN to base of Gilbert). This period initiates the series of increasingly intense carbonate dissolution events, so interpretations of PFZ migrations from the PFI are possibly equivocal. Nevertheless, this period is marked by generally increasing $\delta^{18} \mathrm{O}$ in Hole $704 \mathrm{~A}$ from 5.8 to $5.4 \mathrm{~m}$.y., with several strong glacials $\left(\delta^{18} \mathrm{O}\right.$ maxima at 5.61 and 5.49 m.y.) punctuated with a brief interglacial $\left(\delta^{18} \mathrm{O}\right.$ minimum at $5.54 \mathrm{~m} . \mathrm{y}$.) (Müller et al., this volume) and "upwelling" diatoms from 6.0 to 5.5 m.y. (Fenner, this volume). The first significant ice-rafted debris (5.91 m.y.) occurs at Site 701 (Allen and Warnke, this volume).

5.5-4.8 m.y.: No information (rule 6); late Miocene (Messinian) to early Pliocene carbonate dissolution events. Foraminiferal preservation during this period ranges from poor to barren (Brunner, this volume), so little isotope information is available from the carbonate minima. Data from other sites suggest that these minima coincide with major glacial peaks (Müller et al., this volume). However, diatom and silicoflagellate assemblages indicate high productivity from 5.5 until about $5.38 \mathrm{~m}$.y. followed by a very warm, low-productivity period with the PFZ well south of Site 704 from 5.05 to 4.75 m.y. (Fenner, this volume). Thus this interval likely involved migration of the PFZ from a more northerly position prior to about $5.2 \mathrm{~m}$.y. to a southerly position after $5.0 \mathrm{~m}$.y. This period ended abruptly (4.8 m.y.) with a cessation of carbonate dissolution horizons, a return to a more diverse and better preserved planktonic 
foraminiferal assemblages (Brunner, this volume), and a small peak in ice-rafted debris at Sites 699 and 701 (deglaciation?).

4.8-4.5 m.y.: PFZ migrating southward (rule 2); early Pliocene moderate warming (early Gilbert, Thvera). This continuation of the previous warming interval is associated with trace amounts of ice-rafted debris in Sites 699 and 701 and a brief surface-water cooling or salinity enhancement at $4.66 \mathrm{~m} . \mathrm{y}$. , as indicated by a planktonic $\delta^{18} \mathrm{O}$ maximum (Hodell and Ciesielski, this volume) and by "cool" diatom assemblages between 4.75 and 4.68 m.y. (Fenner, this volume).

4.5-4.4 m.y.: No information (rule 4). However, the PFZ was likely still far south.

4.4-4.2 m.y.: PFZ stationary(?) at far southern location (rules 2 and 5); early Pliocene very warm period (early Gilbert). This period is marked by a major warm event, as indicated at Site 704 by "warm" diatom and silicoflagellate assemblages (Fenner, this volume) and the presence of globorotalid foraminifers (Brunner, this volume). The first major ice-rafted debris at $4.4 \mathrm{~m} . y$. at Site 701 may herald the collapse of the West Antarctic Ice Sheet.

4.2-4.0 m.y.: PFZ migrating northward (rule 3); middle Pliocene moderate cooling (Gilbert, Nunivak). The period from 4.1 to $3.7 \mathrm{~m} . y$. coincides with an increase in planktonic $\delta^{18} \mathrm{O}$ but invariant benthic $\delta^{18} \mathrm{O}$, suggesting that this was a period of surface-water cooling without significant continental ice-volume growth (Hodell and Ciesielski, this volume), indicating migration of the PFZ northward nearer to Site 704. This coincides with trace ice-rafted debris in the far south Atlantic Ocean at about 4 m.y. (Bornhold, 1983) and the first major peak in ice-rafted debris at Site 699 between 4.2 and 4.0 m.y. (Allen and Warnke, this volume), perhaps heralding the reestablishment of glacial erosion on West Antarctica. The initiation at about 4.1-4.0 m.y. of a period of high incidence of upwelling diatoms at Site 704 (Hodell and Ciesielski, this volume) and at DSDP Site 514 (Ciesielski and Grinstead, 1986) suggests migration of the PFZ northward closer to Site 704 . Nevertheless, Site 704 was still north of the Subantarctic Front, as indicated by the dominance of globorotalids rather than Neogloboquadrina pachyderma, the absence of "warm" silicoflagellates (Hodell and Ciesielski, this volume), and the absence of ice-rafted detritus (Allen and Warnke, this volume).

4.0-3.9 m.y.: No information (rule 4), but PFZ is likely at a more northerly position; middle Pliocene cool period (early Gilbert, between Nunivak and Cochiti). There is a large peak in ice-rafted debris at Site 701 between 4.0 and 3.9 m.y. (Allen and Warnke, this volume), but still almost no ice-rafted detritus at Site 704.

3.9-3.6 m.y.: No information (rule 6), but PFZ may be migrating southward (rule 2); early Pliocene moderate warming(?) (Gilbert, above Cochiti). This period is not normally associated with a warming. A strong peak in ice-rafted debris between 3.7 and $3.6 \mathrm{~m} . \mathrm{y}$. at Site 701 may reflect deglaciation of West Antarctica.

3.6-3.3 m.y.: PFZ stationary at a far southern position (rule 5); middle Pliocene very warm period(?) (late Gilbert to base of Gauss). Ruddiman and Janecek (in press) associate this period (about 3.6 to $3.4 \mathrm{~m} . \mathrm{y}$.) with a change to greater range of variation in the abundance of carbonate, opal, and terrigenous fluxes to the eastern equatorial Atlantic Ocean, with greater terrigenous and opal maxima and lower carbonate minima.

3.3-3.2 m.y.: PFZ migrating northward slightly (rule 3); middle Pliocene weak cooling (early Gauss). This brief cooling left no traces of ice-rafted debris at Sites 701 or 704 (Allen and Warnke, this volume) but coincides with a hiatus at Site 699 .
3.2-2.9 m.y.: PFZ almost stationary(?) at intermediate northern position (rules 5 and 3?); middle Pliocene weak cool period (Gauss). From 3.1 to 2.9 m.y., a brief increase in benthic $\delta^{18} \mathrm{O}$ at Site 704 bracketing the Mammoth and Kaena Subchrons suggests a short glacial period that coincides with the first significant occurrence at Site 704 of the diatom Eucampia antarctica since the early Gilbert (Hodell and Ciesielski, this volume). There are pulses of ice-rafted debris at $2.9 \mathrm{~m} . \mathrm{y}$. at Site 699 and between 3.1 and $2.8 \mathrm{~m} . \mathrm{y}$. at Site 701 , but still only traces of ice-rafted debris at Site 704 (Allen and Warnke, this volume). This is the period within which the initial Pliocene-Pleistocene cooling and Northern Hemisphere glacial ice buildup began (Einarsson and Albertsson, 1988).

2.9-2.8 m.y.: PFZ migrating southward slightly (rule 2); middle Pliocene weak warming (Gauss). Decrease in benthịc $\delta^{18} \mathrm{O}$ suggests warming (Hodell and Ciesielski, this volume).

2.8-2.7 m.y.: PFZ migrating northward slightly (rule 3); late Pliocene weak cooling (late Gauss). This period coincides with a dramatic increase in ice-rafted debris at Site 699 (and a hiatus at Site 701) but still only traces of ice-rafted debris at Site 704 (Allen and Warnke, this volume). At about $2.75 \mathrm{~m} . \mathrm{y} .$, the oldest minor traces of ice-rafted debris are also recognized in North Atlantic DSDP Sites 552, 607, and 609 (Raymo et al., 1989, and references therein). If these events mark major advances in continental ice sheets, they do not coincide with a dramatic change in the nature of biogenic deposition (and presumably migration of the PFZ northward) at Site 704. They do, however, correspond to a significant increase in both planktonic and benthic $\delta^{18} \mathrm{O}$ at $175 \mathrm{mbsf}$ in the Hole 704A isotopic record of Hodell and Ciesielski (this volume).

2.7-2.5 m.y.: No information (rule 4); hiatus? This is an important interval for linking Northern and Southern hemisphere paleoceanographic changes during the climatic deterioration leading up to the marked glacial to interglacial fluctuations marking the "onset" of Northern Hemisphere glaciation at 2.4 m.y. (Shackleton et al., 1984). Sedimentation rates in this interval are either very low or vanishing in the subantarctic South Atlantic Ocean, coinciding with marked hiatuses at Sites 699 and 701, and perhaps at Site 704 (dependent upon the placement of the Matuyama/Gauss boundary). The period from 2.75 to 2.60 m.y. is also recognized in the North Atlantic Ocean as one of increasing amplitudes of glacial benthic $\delta^{18} \mathrm{O}$ signals with small amounts of ice-rafted debris in the glacial stages of Sites 607, 609, and 552, suggesting that significant ice sheets began forming and decaying around the North Atlantic by at least 2.65 m.y. (Raymo et al., 1989). Jansen et al. (1988) also observed the first large input of ice-rafted debris in the Norwegian Sea at about $2.56 \mathrm{~m} . y$., which they suggested coincides with a major expansion of the Scandinavian ice sheet. This interval may also correspond to peaks in ice-rafted detritus at about $2.6 \mathrm{~m}$.y. in the South Atlantic (Bornhold, 1983).

2.50-2.45 m.y.: No information (rule 1), but if the PFZ was migrating northward or at a northerly position during this period, it was a weak cooling (Matuyama/Gauss boundary). This marks the beginning of the period of very high sedimentation rates at Site 704 (either very late Gauss or very early Matuyama), very low sedimentation rates at Site 609 in the North Atlantic (Raymo et al., 1989), and a dramatic change in the amplitude of variations in the peaks of opal (equatorial wind-induced upwelling) and terrigenous (African dust) components in equatorial Atlantic sediments (Ruddiman and Janecek, in press), heralding a major change in both atmospheric and oceanic circulation patterns. Jansen et al. (1988) also recognized a permanent shift in benthic $\delta^{13} \mathrm{C}$ in the Norwegian Sea (high values-nutrient-poor-before $2.5 \mathrm{~m} . \mathrm{y}$., to low 
values-nutrient-rich-after $2.4 \mathrm{~m} . \mathrm{y}$.), which they interpreted as reflecting a change in the mode of bottom water formation, leading to speculations about a change in the nature of glacial NADW. Isotope stage 104 (at 2.48 m.y.) in the Site 607 record of Raymo et al. (1989) marks the first significantly low glacial benthic $\delta^{13} \mathrm{C}$ in the North Atlantic and probably heralds the beginning either of glacial suppression of NADW to the North Atlantic or of significant penetration of Southern Component Water into the North Atlantic. Also, between 2.5 and 2.4 m.y., Hodell and Ciesielski (this volume) recognized in their Hole 704A isotopic record a large and "permanent" (until about $1.5 \mathrm{~m} . \mathrm{y}$.) decrease in benthic $\delta^{13} \mathrm{C}$ values not associated with any change in the planktonic values; deep Southern Ocean waters over Site 704 shifted from a more North Atlantic "nutrient-poor" character similar to that of the late Quaternary (sensu that of Site 552) to a more Pacific "nutrient-rich", character (Site 677) (Raymo et al., in press). They interpreted this shift as a decrease in the average influence of Northern Component Water (NADW) at Site 704. All of these changes occur prior to a major increase in continental ice volume and suggest that oceanic nutrient circulation and its links to atmospheric carbon dioxide may have led to the dramatic swings in climate and ice volume that began within the next few hundred thousand years. The dramatic increase in massaccumulation rates on the Meteor Rise at $2.45 \mathrm{~m}$.y. (if the timing is correct) is roughly coincident with the first appearance of significant amounts of ice-rafted detritus in the North Atlantic south of $40^{\circ} \mathrm{N}$.

2.45-2.40 m.y.: PFZ migrating southward (rule 2); late Pliocene moderate warming (early Matuyama). The timing of this brief warm interval is totally dependent upon our placement of the Matuyama/Gauss boundary. With the age model we adopt here, it coincides with the very weak (almost nonexistent) glacial isotope stage 102 at $2.44 \mathrm{~m} . \mathrm{y}$. in the Site 607 record (Raymo et al., 1989). Thus this period in our record coincides with Raymo et al.'s isotope stages 101-103, which were very warm (2.47-2.41 m.y.). It also coincides with the interval of maximum accumulation rates of ice-rafted debris at about $2.45 \mathrm{~m}$.y. at Sites 699 and 701 , and for the first time, at Site 704 (Allen and Warnke, this volume). However, other indicators at Site 704 indicate dramatic cooling and advance of the PFZ near to Site 704, including (1) a decrease in planktonic $\delta^{18} \mathrm{O}$ (Hodell and Ciesielski, this volume), (2) a change in planktonic foraminifers from dominance by globorotalids to Globigerina and N. pachyderma (Brunner, this volume), and (3) northward migration of antarctic assemblages of diatoms and radiolarians observed at other Southern Ocean sites (see references and discussion in Hodell and Ciesielski, this volume).

2.40-2.30 m.y.: PFZ migrating far northward (rule 3); late Pliocene very strong cooling (Matuyama). This interval is a well-recognized period in the lower Matuyama of global cooling of both hemispheres and glacial advance in the Northern Hemisphere, marked as the "onset" of major Northern Hemisphere glaciation (Shackleton et al., 1984). It coincides with highamplitude ice volume changes and the first strong glacial $\delta^{18} \mathrm{O}$ stages 96, 98, and 100 (2.40-2.32 m.y.; Raymo et al., 1989), the first strong glacial suppression of NADW in the North Atlantic $\left(\delta^{13} \mathrm{C}\right.$ minimum in stage 96; Raymo et al., 1989), abundant ice-rafted debris in the Norwegian Sea (2.4-2.3 m.y.; Jansen et al., 1988) and at Site 704 (2.30 m.y.; Allen and Warnke, this volume), and the earliest advance of sea ice to Site 704 as marked by the first common occurrence of $E$. antarctica in the Pliocene (Hodell and Ciesielski, this volume).

2.30-2.10 m.y.: PFZ migrating far southward (rule 2); late Pliocene very strong warming (Matuyama). This interval coincides with low-amplitude ice volume changes and the weak glacial stages 90,92 , and 94 (2.30-2.15 m.y.; Raymo et al., 1989), no ice-rafted debris at Sites 607 and 609 in the North Atlantic during the interval of isotope stages 89-95 (Raymo et al., 1989), and the absence of glacial suppression NADW in the North Atlantic between 2.35 and $2.20 \mathrm{~m}$.y., as indicated by high benthic $\delta^{13} \mathrm{C}$ values at Sites 607 and 609 (Raymo et al., 1989).

2.10-2.00 m.y.: PFZ migrating northward (rule 3); late Pliocene strong cooling (Matuyama). This interval coincides with reinitiation of strong high-amplitude glacial signals (stages 86 and 82 at 2.11 and 2.03 m.y.) and the strongest suppression of glacial NADW ( $\delta^{13} \mathrm{C}$ minimum) during stage 82 in the North Atlantic (Raymo et al., 1989). The strong doublet carbonate minima (opal maxima) at 2.01 to $2.03 \mathrm{~m} . \mathrm{y}$. in the Hole 704A record (Fig. 7) likely coincides with one or both of these two glacial episodes. Hodell and Ciesielski (this volume) recognized this interval in Hole $704 \mathrm{~A}$ as one of maximum $\delta^{18} \mathrm{O}$ in both planktonic and benthic isotope records, maximum abundance of $N$. pachyderma indicating the presence of polar water masses, and peak abundance of $T$. nitzschoides, an indicator of enhanced upwelling and biosiliceous productivity. This interval also contains peak ice-rafted debris at Sites 699 and 701 and at Site 704 (with our time scale) (Allen and Warnke, this volume).

2.00-1.95 m.y.: PFZ migrating southward (rule 2); late Pliocene strong warming (Matuyama). This short interval likely coincides with the very weak glacial stage 80 (between 2.01 and 1.99 m.y.; Raymo et al., 1989) and with a dramatic decrease in ice-rafted debris in the Norwegian Sea (Jansen et al., 1988) and at Sites 699, 701, and 704.

1.95-1.80 m.y.: PFZ migrating far northward (rule 3); latest Pliocene very strong cooling (Matuyama). This interval coincides with one of the strongest glacial stages ( 78 at $1.94 \mathrm{~m} . \mathrm{y}$. ) and the strong glacial stages 74 and 72 (1.86 and 1.83 m.y.) (Raymo et al., 1989). This interval in the other records-for example, a dominance of Neogloboquadrina over globorotalids (Brunner, this volume) and an increase in the percentage of "upwelling"' diatom assemblages (Fenner, this volume)of Hole 704A (about 103 mbsf) indicates an approach of the PFZ northward toward Site 704. This interval coincides with a major peak in the abundance of ice-rafted debris (about 1.9 m.y.) in the South Atlantic sites of Bornhold (1983).

$1.80-1.55$ m.y.: PFZ oscillating in a far northward position (rules 2, 3, and 5); latest Pliocene cold period (Matuyama, Olduvai). This interval coincides with the strong glacial peaks of stages $70,68,66$, and 58 between 1.78 and $1.54 \mathrm{~m} . \mathrm{y}$. (Raymo et al., 1989, in press; Ruddiman et al., 1989). The interval between 98 and 80 mbsf in Hole 704A (1.85-1.55 m.y.) is one of prolonged northerly position of the PFZ, as indicated by an increase in sedimentary organic carbon (Ciesielski, Kristoffersen, et al., 1988) and common to dominant occurrences of $T$. nitzschoides, both indicating strong upwelling and high productivity, and by low planktonic $\delta^{13} \mathrm{C}$ (high surfacewater nutrients) (Hodell and Ciesielski, this volume). A significant peak in ice-rafted debris at 102 mbsf $(1.90$ m.y. $)$ is followed by a dramatic decrease in ice-rafted detritus abundance until a minor peak at $81 \mathrm{mbsf}(1.55 \mathrm{~m} . \mathrm{y}$.) (Warnke and Allen, this volume), suggesting that either the Polar Front migrated north of Site 704 (thus limiting iceberg melt over Site 704; Hodell and Ciesielski, this volume) or the style of glaciation of the West Antarctic Ice Sheet changed from wet-based to very cold, dry-based (Warnke and Allen, this volume).

1.55-1.52 m.y.: PFZ migrating far southward (rule 2); earliest Pleistocene strong warming (Matuyama, above Olduvai). Planktonic $\delta^{18} \mathrm{O}$ values in Hole 704A decrease, indicating either warming and/or melting of glacial ice (Hodell and Ciesielski, this volume). Reinitiation of ice-rafted debris at 
Site 704 at 1.55 m.y. (Warnke and Allen, this volume) may suggest some contribution to the global oceanic $\delta^{18} \mathrm{O}$ signal from the latter.

1.52-1.45 m.y.: PFZ likely stationary in moderate southerly position (rule 5); early Pleistocene very warm period (Matuyama, between Olduvai and Jaramillo). The PFI record suggests that this period is the "warmest" interval between 1.8 and $0.95 \mathrm{~m} . \mathrm{y}$. If the timing in our Site 704 record is approximately correct, this interval coincides with the weak glacial stage $56(1.50 \mathrm{~m} . \mathrm{y}$.$) in the Site 607$ record of the North Atlantic (Ruddiman et al., 1989). Including the bracketing interglacial periods (57-55), this encompasses the warm period from 1.52 to 1.47 m.y. in Ruddiman et al.'s record. Bornhold (1983) observed significant abundances of ice-rafted debris in South Atlantic sites at about $1.5 \mathrm{~m} . \mathrm{y}$.

1.45-1.40 m.y.: PFZ migrating northward (rule 3); early Pleistocene moderate cooling (Matuyama, between Olduvai and Jaramillo). This interval begins the reinitiation of cyclic opal and carbonate deposition on the Meteor Rise during which planktonic and benthic $\delta^{18} \mathrm{O}$ and $\delta^{13} \mathrm{C}$ signals covary $\left(\delta^{18} \mathrm{O}\right.$ and $\delta^{13} \mathrm{C}$ in the opposite sense) and carbonate minima coincide with $\delta^{18} \mathrm{O}$ maxima glacial stages (Hodell and Ciesielski, this volume). This period, including the following "cold" period (1.40-1.30 m.y.), contains the strong glacial isotope stages $54,52,50$, and $48(1.46,1.42,1.37$, and 1.34 m.y.) (Ruddiman et al., 1989). Stage 52 exhibits the lowest glacial benthic $\delta^{13} \mathrm{C}$ signal at Site 607 in the North Atlantic since early in the Matuyama and heralds the $1.4 \mathrm{~m} . \mathrm{y}$. "switch" to strong suppression of glacial NADW that continues through the late Quaternary (Raymo et al., in press).

1.40-1.30 m.y.: PFZ stationary (with minor oscillations) at northerly position (rule 5); late Pleistocene cold period (Matuyama, between Olduvai and Jaramillo). This interval coincides with glacial stages 50 and 48 (see preceding section).

1.30-1.18 m.y.: PFZ migrating southward (rule 2); early Pleistocene moderate warming (Matuyama, between Olduvai and Jaramillo). This interval coincides with the weak glacial stages 46 through 40 (1.29-1.17 m.y.), containing the very "warm" interglacial stage 43 (1.23 m.y.) (Ruddiman et al., 1989). It also coincides with a period of less dramatic suppression of NADW at Site 607 (Raymo et al., in press).

From this interval upward into the Jaramillo, the glacial and interglacial stages in the isotopic record of Hole $704 \mathrm{~A}$ were matched with those of Ruddiman et al. (1989) (see discussion in Hodell and Ciesielski, this volume). These coincide directly with PFZ migrations as reflected in alternating opal and carbonate accumulation rates that drive changes in the PFI.

1.18-1.14 m.y.: PFZ migrating northward (rule 3); early Pleistocene moderate cooling (Matuyama, below Jaramillo). This interval is probably represented by one glacial stage, 38 (1.13 m.y.).

1.14-1.11 m.y.: PFZ migrating southward (rule 2); early Pleistocene moderate warming (Matuyama, below Jaramillo). This interval probably coincides with the single strong interglacial stage 37 (1.11 m.y.).

1.11-1.06 m.y.: PFZ migrating northward (rule 3); early Pleistocene moderate cooling (Matuyama, below Jaramillo). This interval coincides with glacial stage 36 (1.09 m.y.).

1.06-0.93 m.y.: PFZ migrating southward (with a few oscillations) (rule 2); middle Pleistocene strong warming (Matuyama, within base of Jaramillo). This probably corresponds with the period from the strong glacial (stage 34, 1.05 m.y.) through a very weak glacial (stage $32,1.01 \mathrm{~m} . \mathrm{y}$.) to a very "warm" interglacial (stage $31,0.98 \mathrm{~m}$.y.). Stage 31 may correspond with the "warmest" interval in the Site 704 PFI record (at $0.94 \mathrm{~m} . \mathrm{y}$.) between $1.95 \mathrm{~m} . \mathrm{y}$. and the Brunhes.
Above the base of the Jaramillo in the composite depth record of Site 704 ( $0.98 \mathrm{~m}$.y. at $46.6 \mathrm{mbT})$, the correspondence between records is lost, presumably due to the coring disturbance, which becomes progressively worse higher in the section.

\section{ACKNOWLEDGMENTS}

We are indebted to Joe Powers and Matt Mefferd, who ran many of the shipboard carbonate analyses. Stephen Bloomer (University of Waterloo) assisted in the identification of the color correlations. Funding was provided by grants from the National Science Foundation (OCE-87-11588) and JOI/USSAC (TAMRF-20116). This is Lamont-Doherty Geological Observatory Contribution No. 4684.

\section{REFERENCES}

Barron, J. A., Keller, G., and Dunn, D. A., 1985. A multiple microfossil biochronology for the Miocene. In Kennett, J. P. (Ed.), The Miocene Ocean: Paleoceangraphy and Biogeography. Mem. Geol. Soc. Am., 163:21-36.

Berggren, W. A., Kent, D. V., Flynn, J. J., and Van Couvering, J. A., 1985. Cenozoic geochronology. Geol. Soc. Am. Bull., 96:14071418.

Bornhold, B. D., 1983. Ice-rafted debris in sediments from Leg 71, southwest Atlantic Ocean. In Ludwig, W. J., Krasheninnikov, V, A., et al., Init. Repts. DSDP, 71: Washington (U.S. Govt. Printing Office), 307-316.

Broecker, W. S., and Peng, T.-H., 1982. Tracers in the Sea: Palisades, NY (Eldigio Press).

Ciesielski, P. F., and Grinstead, G. P., 1986. Pliocene variations in the position of the Antarctic Convergence in the southwest Atlantic. Paleoceanography, 1:197-232.

Ciesielski, P. F., Kristoffersen, Y., et al., 1988. Proc. ODP, Init. Repts., 114: College Station, TX (Ocean Drilling Program).

Dunn, D. A., 1982. Miocene sediments of the equatorial Pacific Ocean: carbonate stratigraphy and dissolution history [Ph.D. dissert.]. Univ. Rhode Island, Kingston.

Dunn, D. A., and Moore, T. C., 1981. Late Miocene-Pliocene (magnetic epoch 9-Gilbert magnetic epoch) calcium carbonate stratigraphy of the equatorial Pacific Ocean. Geol. Soc. Am. Bull., 92:408-451.

Einarsson, T., and Albertsson, K. J., 1988. The glacial history of Iceland during the past three million years. In Shackleton, N. J., West, R. G., and Bowern, D. Q. (Eds.), The Past Three Million Years: Evolution of Climatic Variability in the North Atlantic Region: Cambridge (Cambridge Univ. Press), 227-234.

Farrell, J. W., and Prell, W. L., 1989. Climatic change and $\mathrm{CaCO}_{3}$ preservation: an 800,000 year bathymetric reconstruction from the central equatorial Pacific Ocean. Paleoceanography, 4:447466.

Hays, J. D., Irving, G., and King, D., in press. Phyletic and geographic morphologic change in the radiolarian species Cycladophora davisiana. In Geologic History of the Polar Oceans: Arctic versus Antarctic. NATO ASI Ser.

Hays, J. D., and Opdyke, N. D., 1967. Antarctic radiolaria, magnetic reversals, and climate change. Science, 158:1001-1011.

Hays, J. D., Saito, T., Opdyke, N. D., and Burckle, L. H., 1969. Pliocene-Pleistocene sediments of the equatorial Pacific: their paleomagnetic, biostratigraphic, and climatic record. Geol. Soc. Am. Bull., 80:1481-1513.

Jansen, E., Bleil, U., Henrich, R., Kringstad, L., and Slettemark, B., 1988. Paleoenvironmental changes in the Norwegian Sea and northeast Atlantic during the last 2.8 m.y.: Deep-Sea Drilling Project/Ocean Drilling Program Sites 610, 642, 643, and 644. Paleoceanography, 3:563-581.

Jones, G. A., and Kaiteris, P., 1983. A vacuum-gasometric technique for rapid and precise analysis of calcium carbonate in sediments and soils. J. Sediment. Petrol., 53:655-660.

Keller, G., and Barron, J. A., 1987. Paleodepth distribution of Neogene deep-sea hiatuses. Paleoceanography, 2:697-713. 
Leinen, M., Cwienk, D., Heath, G. R., Biscaye, P. E., Kolla, V., Thiede, J., and Dauphin, J. P., 1986. Distribution of biogenic silica and quartz in recent deep-sea sediments. Geology, 14:199-203.

Lyle, M., Murray, D. W., Finney, B. P., Dymond, J., Robbins, J. M., and Brooksforce, K., 1988. The record of late Pleistocene biogenic sedimentation in the eastern tropical Pacific Ocean. Paleoceanography, 3:39-59.

Martinson, D. G., Menke, W., and Stoffa, P., 1982. An inverse approach to signal correlation. J. Geophys. Res., 87:4807-4818.

Mortlock, R. A., and Froelich, P. N., in press. A simple method for the rapid determination of biogenic opal in pelagic marine sediments. Deep-Sea Res., Part A.

Müller, D. W., and Hsü, K. J., 1987. Event stratigraphy and paleoceanography in the Fortuna Basin (Southeast Spain): a scenario for the Messinian salinity crises. Paleoceanography, 2:679-696.

Pisias, N. G., and Leinen, M., 1984. Late Pleistocene variability of the northwest sector of the Pacific Ocean. In Cline, R. M., and Hays, J. D. (Eds.), Investigations of Late Quaternary Paleoceanography and Paleoclimatology. Mem. Soc. Geol. Am., 145:375392.

Prell, W. L., 1985. Pliocene stable isotope and carbonate stratigraphy (Holes 572C and 573A): paleoceanographic data bearing on the question of Pliocene glaciation. In Mayer, L., Theyer, F., Thomas, E., et al., Init. Repts. DSDP, 85: Washington (U.S. Govt. Printing Office), 723-734.

Raymo, M. E., Ruddiman, W. F., Backman, J., Clement, B. M., and Martinson, D. G., 1989. Late Pliocene variation in Northern Hemisphere ice sheets and North Atlantic deep water circulation. Paleoceanography, 4:413-446.
Raymo, M. E., Ruddiman, W. F., Shackleton, N. J., and Oppo, D. W., in press. Evolution of global ice volume and Atlantic-Pacific $\delta^{13} \mathrm{C}$ gradients over the last 2.5 m.y. Earth Planet. Sci. Lett.

Ruddiman, W. F., and Janecek, T. R., in press. Pliocene-Pleistocene biogenic and terrigenous fluxes at equatorial Atlantic Sites 662, 663, and 664. In Ruddiman, W. F., Sarnthein, M., et al., Proc. ODP, Sci. Results, 108: College Station, TX (Ocean Drilling Program).

Ruddiman, W. F., Raymo, M. E., Martinson, D. G., Clement, B. M., and Backman, J., 1989. Pleistocene evolution: Northern Hemisphere ice sheets and North Atlantic Ocean. Paleoceanography, $4: 353-412$.

Saito, T., Burckle, L. H., and Hays, J. D., 1975. Late Miocene to Pleistocene biostratigraphy of equatorial Pacific sediments. In Saito, T., and Burckle, L. H. (Eds.), Late Neogene Epoch Boundaries: New York (Micropaleontology Press), 226-244.

Shackleton, N. J., Backman, J., Zimmerman, H., Kent, D. V., Hall, M. A., Roberts, D. G., Schnitker, D., and Baldauf, J., 1984. Oxygen isotopic calibration of the onset of ice-rafting and history of glaciation in the North Atlantic region. Nature, 307:620-623.

Vincent, E., 1981. Neogene carbonate stratigraphy of Hess Rise (central North Pacific) and paleoceanographic implications. In Thiede, J., Vallier, T. L., et al., Init. Repts. DSDP, 62: Washington (U.S. Govt. Printing Office), 571-606.

Date of initial receipt: 18 April 1989

Date of acceptance: 16 November 1989

Ms 114B-149 
APPENDIX

Percent Carbonate, Opal, and Other Sediment Components, Holes 704A and 704B

\begin{tabular}{|c|c|c|c|c|}
\hline $\begin{array}{l}\text { Core, section, } \\
\text { interval }(\mathrm{cm})\end{array}$ & $\begin{array}{l}\text { Depth } \\
\text { (mbsf) }\end{array}$ & $\begin{array}{c}\mathrm{CaCO}_{3} \\
(\%)\end{array}$ & $\begin{array}{l}\text { Opal } \\
(\%)\end{array}$ & $\begin{array}{l}\text { Other } \\
(\%)\end{array}$ \\
\hline \multicolumn{5}{|l|}{$114-704 \mathrm{~A}-$} \\
\hline $1 \mathrm{H}-1,10-14$ & 0.12 & 82.42 & & \\
\hline $1 \mathrm{H}-1,16-17$ & 0.16 & 82.99 & 4.95 & 12.05 \\
\hline $1 \mathrm{H}-1,40-42$ & 0.41 & 39.42 & & \\
\hline $1 \mathrm{H}-1,69-70$ & 0.69 & 45.17 & 28.84 & 25.98 \\
\hline $1 \mathrm{H}-1,76-78$ & 0.78 & 44.83 & & \\
\hline $1 \mathrm{H}-1,100-102$ & 1.01 & 51.62 & & \\
\hline $1 \mathrm{H}-\mathrm{I}, 104-105$ & 1.04 & 64.48 & 20.22 & 15.29 \\
\hline $1 \mathrm{H}-1,108-110$ & 1.09 & 62.75 & & \\
\hline $1 \mathrm{H}-1,136-137$ & 1.36 & 76.80 & 12.42 & 10.77 \\
\hline $1 \mathrm{H}-2,15-16$ & 1.65 & 66.06 & 19.02 & 14.91 \\
\hline $1 \mathrm{H}-2,40-42$ & 1.91 & 57.92 & & \\
\hline $1 \mathrm{H}-2,45-46$ & 1.95 & 55.40 & 22.40 & 22.19 \\
\hline $1 \mathrm{H}-2,70-74$ & 2.22 & 68.50 & & \\
\hline $1 \mathrm{H}-2,76-80$ & 2.28 & 70.08 & & \\
\hline $1 \mathrm{H}-2,81-82$ & 2.31 & 74.19 & 12.29 & 13.51 \\
\hline $1 \mathrm{H}-2,100-102$ & 2.51 & 85.74 & & \\
\hline $1 \mathrm{H}-2,105-106$ & 2.55 & 82.25 & 7.84 & 9.90 \\
\hline $1 \mathrm{H}-2,108-112$ & 2.60 & 78.59 & & \\
\hline $1 \mathrm{H}-2,128-129$ & 2.78 & 52.83 & 16.63 & 30.53 \\
\hline $1 \mathrm{H}-2,145-149$ & 2.95 & 29.55 & 35.26 & 35.18 \\
\hline $1 \mathrm{H}-3,0-5$ & 3.01 & 33.34 & 32.27 & 34.38 \\
\hline $1 \mathrm{H}-3,10-14$ & 3.12 & 29.58 & & \\
\hline $1 \mathrm{H}-3,15-16$ & 3.15 & 37.24 & 27.04 & 35.71 \\
\hline $1 \mathrm{H}-3,40-42$ & 3.41 & 28.50 & & \\
\hline $1 \mathrm{H}-3,52-56$ & 3.52 & 24.12 & 27.11 & 48.76 \\
\hline $1 \mathrm{H}-3,76-80$ & 3.78 & 37.92 & & \\
\hline $1 \mathrm{H}-3,80-81$ & 3.80 & 46.36 & 20.50 & 33.14 \\
\hline $1 \mathrm{H}-3,100-102$ & 4.01 & 36.20 & & \\
\hline $1 \mathrm{H}-3,104-105$ & 4.04 & 47.38 & 20.57 & 32.04 \\
\hline $1 \mathrm{H}-3,108-112$ & 4.10 & 42.33 & & \\
\hline $1 \mathrm{H}-3,125-126$ & 4.25 & 49.68 & 20.07 & 30.24 \\
\hline $1 \mathrm{H}-3,135-136$ & 4.35 & 63.50 & 18.85 & 17.64 \\
\hline $1 \mathrm{H}-4,15-16$ & 4.65 & 92.58 & 2.28 & 5.13 \\
\hline $1 \mathrm{H}-4,40-42$ & 4.91 & 96.08 & & \\
\hline $1 \mathrm{H}-4,45-46$ & 4.95 & 95.75 & 0.87 & 3.37 \\
\hline $1 \mathrm{H}-4,66-70$ & 5.16 & 68.27 & 15.12 & 16.61 \\
\hline $1 \mathrm{H}-4,70-72$ & 5.22 & 60.17 & & \\
\hline $1 \mathrm{H}-4,76-80$ & 5.28 & 53.92 & & \\
\hline $1 \mathrm{H}-4,81-82$ & 5.31 & 58.43 & 21.00 & 20.56 \\
\hline $1 \mathrm{H}-4,103-104$ & 5.53 & 92.49 & 2.19 & 5.31 \\
\hline $1 \mathrm{H}-4,108-112$ & 5.60 & 94.25 & & \\
\hline $1 \mathrm{H}-4,123-127$ & 5.75 & 94.17 & & \\
\hline $1 \mathrm{H}-4,130-132$ & 5.81 & 92.32 & & \\
\hline $1 \mathrm{H}-4,135-136$ & 5.85 & 96.89 & 0.77 & 2.34 \\
\hline $1 \mathrm{H}-4,145-150$ & 5.96 & 93.43 & 0.80 & 5.76 \\
\hline $1 \mathrm{H}-5,10-14$ & 6.12 & 93.08 & & \\
\hline $1 H-5,15-16$ & 6.15 & 95.95 & 0.71 & 3.33 \\
\hline $1 \mathrm{H}-5,19-23$ & 6.21 & 70.00 & & \\
\hline $1 \mathrm{H}-5,40-42$ & 6.41 & 92.67 & & \\
\hline $1 \mathrm{H}-5,45-46$ & 6.45 & 95.95 & 0.71 & 3.33 \\
\hline $1 \mathrm{H}-5,69-70$ & 6.69 & 95.56 & 1.01 & 3.42 \\
\hline $1 \mathrm{H}-5,76-80$ & 6.78 & 91.33 & & \\
\hline $1 \mathrm{H}-5,100-101$ & 7.00 & 41.47 & 39.80 & 18.72 \\
\hline $1 \mathrm{H}-5,108-112$ & 7.10 & 43.42 & & \\
\hline $1 \mathrm{H}-5,112-116$ & 7.11 & 35.73 & 39.49 & 24.78 \\
\hline $1 \mathrm{H}-5,111-113$ & 7.12 & 24.52 & & \\
\hline $2 \mathrm{H}-1,10-14$ & 7.30 & 97.94 & 0.58 & 1.47 \\
\hline $2 \mathrm{H}-1,30-32$ & 7.51 & 94.24 & & \\
\hline $2 \mathrm{H}-1,40-42$ & 7.61 & 93.25 & & \\
\hline $2 \mathrm{H}-1,45-46$ & 7.65 & 96.51 & 0.81 & 2.67 \\
\hline $2 \mathrm{H}-1,64-68$ & 7.86 & 93.42 & & \\
\hline $2 \mathrm{H}-1,74-75$ & 7.94 & 92.38 & 1.36 & 6.25 \\
\hline $2 \mathrm{H}-1,80-84$ & 8.02 & 90.67 & & \\
\hline $2 \mathrm{H}-1,100-102$ & 8.21 & 68.89 & & \\
\hline $2 \mathrm{H}-1,102-103$ & 8.22 & 63.65 & 9.54 & 26.80 \\
\hline $2 \mathrm{H}-\mathrm{I}, 130-134$ & 8.52 & 34.25 & & \\
\hline $2 \mathrm{H}-1,135-136$ & 8.55 & 44.09 & 20.29 & 35.61 \\
\hline $2 \mathrm{H}-2,10-14$ & 8.80 & 73.35 & 8.81 & 17.67 \\
\hline $2 \mathrm{H}-2,30-34$ & 9.02 & 48.67 & & \\
\hline $2 \mathrm{H}-2,40-42$ & 9.11 & 19.25 & & \\
\hline $2 \mathrm{H}-2,45-46$ & 9.15 & 28.53 & 48.13 & 23.33 \\
\hline $2 \mathrm{H}-2,74-75$ & 9.44 & 59.16 & 22.51 & 18.33 \\
\hline $2 \mathrm{H}-2,80-84$ & 9.52 & 56.83 & & \\
\hline $2 \mathrm{H}-2,103-104$ & 9.73 & 36.16 & 31.80 & 32.03 \\
\hline $2 \mathrm{H}-2,130-134$ & 10.02 & 3.58 & & \\
\hline
\end{tabular}

APPENDIX (continued).

\begin{tabular}{|c|c|c|c|c|}
\hline $\begin{array}{l}\text { Core, section, } \\
\text { interval }(\mathrm{cm})\end{array}$ & $\begin{array}{l}\text { Depth } \\
\text { (mbsf) }\end{array}$ & $\begin{array}{l}\mathrm{CaCO}_{3} \\
(\%)\end{array}$ & $\begin{array}{l}\text { Opal } \\
(\%)\end{array}$ & $\begin{array}{l}\text { Other } \\
(\%)\end{array}$ \\
\hline $2 \mathrm{H}-2,135-136$ & 10.05 & 29.63 & 40.05 & 30.31 \\
\hline $2 \mathrm{H}-3,0-5$ & 10.20 & 11.66 & 59.09 & 29.24 \\
\hline $2 \mathrm{H}-3,10-14$ & 10.30 & 11.63 & 66.11 & 22.25 \\
\hline $2 \mathrm{H}-3,40-42$ & 10.61 & 14.25 & & \\
\hline $2 \mathrm{H}-3,47-48$ & 10.67 & 7.18 & 58.58 & 34.23 \\
\hline $2 \mathrm{H}-3,76-77$ & 10.96 & 12.79 & 56.44 & 30.77 \\
\hline $2 \mathrm{H}-3,80-84$ & 11.02 & 7.92 & & \\
\hline $2 \mathrm{H}-3,100-102$ & 11.21 & 6.76 & & \\
\hline $2 \mathrm{H}-3,104-105$ & 11.24 & 6.93 & 68.92 & 24.15 \\
\hline $2 \mathrm{H}-3,130-134$ & 11.52 & 7.50 & & \\
\hline $2 \mathrm{H}-3,134-135$ & 11.54 & 11.47 & 62.80 & 25.72 \\
\hline $2 \mathrm{H}-3,140-144$ & 11.62 & 14.67 & & \\
\hline $2 \mathrm{H}-4,10-14$ & 11.80 & 25.65 & 49.56 & 24.78 \\
\hline $2 \mathrm{H}-4,40-42$ & 12.11 & 39.92 & & \\
\hline $2 \mathrm{H}-4,45-46$ & 12.15 & 41.30 & 27.93 & 30.76 \\
\hline $2 \mathrm{H}-4,69-70$ & 12.39 & 78.51 & 10.36 & 11.12 \\
\hline $2 \mathrm{H}-4,80-84$ & 12.52 & 79.75 & & \\
\hline $2 \mathrm{H}-4,100-102$ & 12.71 & 70.39 & & \\
\hline $2 \mathrm{H}-4,103-104$ & 12.73 & 61.26 & 27.01 & 11.72 \\
\hline $2 \mathrm{H}-4,130-134$ & 13.02 & 28.75 & & \\
\hline $2 \mathrm{H}-4,134-135$ & 13.04 & 34.92 & 48.15 & 16.92 \\
\hline $2 \mathrm{H}-4,140-142$ & 13.11 & 46.83 & & \\
\hline $2 \mathrm{H}-5,10-14$ & 13.30 & 61.02 & 23.23 & 15.74 \\
\hline $2 \mathrm{H}-5,30-34$ & 13.52 & 62.50 & & \\
\hline $2 \mathrm{H}-5,81-82$ & 14.01 & 59.20 & 23.26 & 17.53 \\
\hline $2 \mathrm{H}-5,100-102$ & 14.21 & 61.80 & & \\
\hline $2 \mathrm{H}-5,130-134$ & 14.52 & 50.00 & & \\
\hline $2 \mathrm{H}-6,10-14$ & 14.80 & 70.32 & 14.56 & 15.11 \\
\hline $2 \mathrm{H}-6,40-42$ & 15.11 & 79.92 & & \\
\hline $2 \mathrm{H}-6,45-46$ & 15.15 & 81.48 & 4.73 & 13.78 \\
\hline $2 \mathrm{H}-6,64-68$ & 15.36 & 57.42 & & \\
\hline $2 \mathrm{H}-6,74-75$ & 15.44 & 43.34 & 33.05 & 23.60 \\
\hline $2 \mathrm{H}-6,108-109$ & 15.78 & 27.50 & 45.11 & 27.38 \\
\hline $2 \mathrm{H}-6,128-129$ & 15.98 & 43.38 & 26.12 & 30.49 \\
\hline $2 \mathrm{H}-6,130-132$ & 16.01 & 20.60 & & \\
\hline $2 \mathrm{H}-6,130-134$ & 16.02 & 41.75 & & \\
\hline $2 \mathrm{H}-7,10-14$ & 16.30 & 55.89 & 18.87 & 25.23 \\
\hline $2 \mathrm{H}-7,40-42$ & 16.61 & 29.00 & & \\
\hline $3 \mathrm{H}-1,20-24$ & 16.90 & 20.08 & 52.55 & 27.36 \\
\hline $3 \mathrm{H}-1,26-30$ & 16.98 & 21.83 & & \\
\hline $3 \mathrm{H}-1,30-32$ & 17.01 & 25.44 & & \\
\hline $3 \mathrm{H}-1,47-48$ & 17.17 & 40.36 & 36.18 & 23.45 \\
\hline $3 \mathrm{H}-1,72-73$ & 17.42 & 70.41 & 15.51 & 14.07 \\
\hline $3 \mathrm{H}-1,80-84$ & 17.52 & 62.83 & & \\
\hline $3 \mathrm{H}-1,100-102$ & 17.71 & 61.38 & & \\
\hline $3 \mathrm{H}-1,106-107$ & 17.76 & 58.40 & 24.27 & 17.32 \\
\hline $3 \mathrm{H}-1,115-117$ & 17.86 & 52.33 & & \\
\hline $3 \mathrm{H}-1,130-134$ & 18.02 & 55.92 & & \\
\hline $3 \mathrm{H}-1,138-139$ & 18.08 & 64.49 & 21.95 & 13.55 \\
\hline $3 \mathrm{H}-2,20-24$ & 18.40 & 45.78 & 30.79 & 23.42 \\
\hline $3 \mathrm{H}-2,26-30$ & 18.48 & 37.92 & & \\
\hline $3 \mathrm{H}-2,47-48$ & 18.67 & 39.98 & 34.85 & 25.16 \\
\hline $3 \mathrm{H}-2,74-75$ & 18.94 & 48.31 & 33.09 & 18.59 \\
\hline $3 \mathrm{H}-2,80-84$ & 19.02 & 39.50 & & \\
\hline $3 \mathrm{H}-2,100-102$ & 19.21 & 38.78 & & \\
\hline $3 \mathrm{H}-2,104-105$ & 19.24 & 42.00 & 34.89 & 23.10 \\
\hline $3 \mathrm{H}-2,115-117$ & 19.36 & 32.17 & & \\
\hline $3 \mathrm{H}-2,130-134$ & 19.52 & 52.08 & & \\
\hline $3 \mathrm{H}-2,139-140$ & 19.59 & 53.36 & 26.31 & 20.32 \\
\hline $3 \mathrm{H}-3,0-5$ & 19.70 & 51.26 & 22.12 & 26.62 \\
\hline $3 \mathrm{H}-3,20-24$ & 19.90 & 66.54 & 15.80 & 17.66 \\
\hline $3 \mathrm{H}-3,26-30$ & 19.98 & 48.42 & & \\
\hline $3 \mathrm{H}-3,69-70$ & 20.39 & 53.66 & 26.10 & 20.23 \\
\hline $3 \mathrm{H}-3,80-84$ & 20.52 & 50.25 & & \\
\hline $3 \mathrm{H}-3,110-112$ & 20.81 & 61.55 & & \\
\hline $3 \mathrm{H}-3,115-117$ & 20.86 & 45.83 & & \\
\hline $3 \mathrm{H}-3,130-134$ & 21.02 & 57.67 & & \\
\hline $3 \mathrm{H}-4,20-24$ & 21.40 & 45.45 & 29.83 & 24.71 \\
\hline $3 \mathrm{H}-4,26-30$ & 21.48 & 43.58 & & \\
\hline $3 \mathrm{H}-4,40-44$ & 21.62 & 46.25 & & \\
\hline $3 \mathrm{H}-4,45-46$ & 21.65 & 49.63 & 15.63 & 34.73 \\
\hline $3 \mathrm{H}-4,74-75$ & 21.94 & 60.16 & 13.99 & 25.84 \\
\hline $3 \mathrm{H}-4,80-84$ & 22.02 & 61.29 & & \\
\hline $3 \mathrm{H}-4,101-102$ & 22.21 & 37.18 & 34.45 & 28.36 \\
\hline $3 \mathrm{H}-4,135-136$ & 22.55 & 56.10 & 21.87 & 22.02 \\
\hline $3 \mathrm{H}-5,20-24$ & 22.90 & 56.83 & 18.87 & 24.29 \\
\hline $3 \mathrm{H}-5,26-30$ & 22.98 & 43.83 & & \\
\hline
\end{tabular}


APPENDIX (continued).

\begin{tabular}{|c|c|c|c|c|}
\hline $\begin{array}{l}\text { Core, section, } \\
\text { interval }(\mathrm{cm})\end{array}$ & $\begin{array}{l}\text { Depth } \\
\text { (mbsf) }\end{array}$ & $\begin{array}{c}\mathrm{CaCO}_{3} \\
(\%)\end{array}$ & $\begin{array}{l}\text { Opal } \\
(\%)\end{array}$ & $\begin{array}{l}\text { Other } \\
(\%)\end{array}$ \\
\hline $3 \mathrm{H}-5,45-46$ & 23.15 & 49.48 & 25.29 & 25.22 \\
\hline $3 \mathrm{H}-5,74-75$ & 23.44 & 62.71 & 20.24 & 17.04 \\
\hline $3 \mathrm{H}-5,80-84$ & 23.52 & 64.92 & & \\
\hline $3 \mathrm{H}-5,96-100$ & 23.68 & 61.67 & & \\
\hline $3 \mathrm{H}-5,104-105$ & 23.74 & 56.77 & 23.61 & 19.61 \\
\hline $3 \mathrm{H}-5,115-117$ & 23.86 & 42.92 & & \\
\hline $3 \mathrm{H}-5,145-150$ & 24.26 & 80.16 & 10.92 & 8.92 \\
\hline $3 \mathrm{H}-6,20-24$ & 24.40 & 78.89 & 9.12 & 11.98 \\
\hline $3 \mathrm{H}-6,26-30$ & 24.48 & 76.00 & & \\
\hline $3 \mathrm{H}-6,72-73$ & 24.92 & 75.38 & 11.43 & 13.18 \\
\hline $3 \mathrm{H}-6,80-84$ & 25.02 & 73.08 & & \\
\hline $3 \mathrm{H}-6,96-100$ & 25.18 & 77.25 & & \\
\hline $3 \mathrm{H}-6,115-117$ & 25.36 & 71.75 & & \\
\hline $4 \mathrm{H}-1,59-60$ & 26.79 & 75.30 & 11.18 & 13.51 \\
\hline $4 \mathrm{H}-2,49-50$ & 28.19 & 78.12 & 9.62 & 12.25 \\
\hline $4 \mathrm{H}-2,105-106$ & 28.75 & 83.98 & 6.73 & 9.28 \\
\hline $4 \mathrm{H}-3,0-5$ & 29.21 & 70.02 & 15.92 & 14.06 \\
\hline $4 \mathrm{H}-3,20-22$ & 29.41 & 83.40 & & \\
\hline $4 \mathrm{H}-3,25-26$ & 29.45 & 83.85 & 6.77 & 9.37 \\
\hline $4 \mathrm{H}-3,45-46$ & 29.55 & 68.06 & 6.85 & 25.08 \\
\hline $4 \mathrm{H}-3,75-76$ & 29.95 & 75.12 & 12.53 & 12.34 \\
\hline $4 \mathrm{H}-3,100-102$ & 30.21 & 52.21 & & \\
\hline $4 \mathrm{H}-3,105-106$ & 30.25 & 57.70 & 24.66 & 17.63 \\
\hline $4 \mathrm{H}-3,135-136$ & 30.55 & 56.87 & 26.38 & 16.74 \\
\hline $4 \mathrm{H}-3,138-142$ & 30.58 & 57.11 & 26.10 & 16.79 \\
\hline $4 \mathrm{H}-4,84-85$ & 31.54 & 58.15 & 24.30 & 17.54 \\
\hline $4 \mathrm{H}-5,74-75$ & 32.94 & 75.96 & 6.74 & 17.30 \\
\hline $4 \mathrm{H}-5,80-82$ & 33.01 & 65.39 & & \\
\hline $4 \mathrm{H}-6,18-22$ & 33.88 & 41.63 & 32.64 & 25.73 \\
\hline $4 \mathrm{H}-6,29-30$ & 33.99 & 40.42 & 37.23 & 22.34 \\
\hline $4 \mathrm{H}-6,35-37$ & 34.06 & 36.36 & & \\
\hline $4 \mathrm{H}-6,38-42$ & 34.10 & 44.17 & & \\
\hline $4 \mathrm{H}-6,49-50$ & 34.19 & 53.25 & 26.02 & 20.72 \\
\hline $5 \mathrm{H}-1,20-22$ & 35.91 & 59.25 & & \\
\hline $5 \mathrm{H}-1,50-52$ & 36.21 & 59.17 & & \\
\hline $5 \mathrm{H}-1,69-70$ & 36.39 & 71.80 & 11.50 & 16.70 \\
\hline $5 \mathrm{H}-1,80-82$ & 36.51 & 79.33 & & \\
\hline $5 \mathrm{H}-1,100-102$ & 36.71 & 85.57 & & \\
\hline $5 \mathrm{H}-2,20-22$ & 37.41 & 66.75 & & \\
\hline $5 \mathrm{H}-2,50-52$ & 37.71 & 66.58 & & \\
\hline $5 \mathrm{H}-2,70-71$ & 37.90 & 72.82 & 11.78 & 15.39 \\
\hline $5 \mathrm{H}-2,80-82$ & 38.01 & 68.50 & & \\
\hline $5 \mathrm{H}-3,15-16$ & 38.85 & 32.94 & 32.42 & 34.64 \\
\hline $5 \mathrm{H}-3,20-22$ & 38.91 & 37.08 & & \\
\hline $5 \mathrm{H}-3,29-33$ & 39.01 & 36.50 & & \\
\hline $5 \mathrm{H}-3,45-46$ & 39.15 & 39.47 & 28.28 & 32.24 \\
\hline $5 \mathrm{H}-3,50-52$ & 39.21 & 38.54 & & \\
\hline $5 \mathrm{H}-3,75-76$ & 39.45 & 43.16 & 28.59 & 28.24 \\
\hline $5 \mathrm{H}-3,100-102$ & 39.71 & 38.53 & & \\
\hline $5 \mathrm{H}-3,106-107$ & 39.76 & 40.39 & 27.82 & 31.78 \\
\hline $5 \mathrm{H}-3,132-133$ & 40.02 & 42.03 & 27.37 & 30.59 \\
\hline $5 \mathrm{H}-4,14-15$ & 40.34 & 40.55 & 29.27 & 30.17 \\
\hline $5 \mathrm{H}-4,20-22$ & 40.41 & 33.33 & & \\
\hline $5 \mathrm{H}-4,32-33$ & 40.52 & 38.92 & 28.84 & 32.23 \\
\hline $5 \mathrm{H}-4,47-48$ & 40.67 & 40.66 & 31.90 & 27.43 \\
\hline $5 \mathrm{H}-4,50-52$ & 40.71 & 32.42 & & \\
\hline $5 \mathrm{H}-4,75-76$ & 40.95 & 37.96 & 33.82 & 28.21 \\
\hline $5 \mathrm{H}-4,80-82$ & 41.01 & 34.17 & & \\
\hline $5 \mathrm{H}-4,100-102$ & 41.21 & 30.61 & & \\
\hline $5 \mathrm{H}-4,106-107$ & 41.26 & 36.56 & 33.48 & 29.95 \\
\hline $5 \mathrm{H}-4,135-136$ & 41.55 & 68.46 & 13.83 & 17.70 \\
\hline $5 \mathrm{H}-5,15-16$ & 41.85 & 75.28 & 11.31 & 13.40 \\
\hline $5 \mathrm{H}-5,20-22$ & 41.91 & 66.96 & & \\
\hline $5 \mathrm{H}-5,45-46$ & 42.15 & 74.57 & 14.59 & 10.83 \\
\hline $5 \mathrm{H}-5,50-52$ & 42.21 & 67.67 & & \\
\hline $5 \mathrm{H}-5,77-78$ & 42.47 & 68.16 & 14.90 & 16.93 \\
\hline $5 \mathrm{H}-5,100-102$ & 42.71 & 73.73 & & \\
\hline $5 \mathrm{H}-5,103-104$ & 42.73 & 73.47 & 12.23 & 14.30 \\
\hline $5 \mathrm{H}-5,130-131$ & 43.00 & 61.83 & 23.40 & 14.76 \\
\hline $5 \mathrm{H}-5,140-142$ & 43.11 & 54.33 & & \\
\hline $5 \mathrm{H}-5,145-149$ & 43.15 & 64.21 & 17.83 & 17.95 \\
\hline $5 \mathrm{H}-6,15-16$ & 43.35 & 62.71 & 22.42 & 14.86 \\
\hline $5 \mathrm{H}-6,29-33$ & 43.51 & 18.42 & & \\
\hline $5 \mathrm{H}-6,45-46$ & 43.65 & 21.81 & 53.66 & 24.52 \\
\hline $5 \mathrm{H}-6,50-52$ & 43.71 & 18.50 & & \\
\hline $5 \mathrm{H}-6,77-78$ & 43.97 & 21.05 & 52.93 & 26.01 \\
\hline $5 \mathrm{H}-6,80-82$ & 44.01 & 21.59 & & \\
\hline
\end{tabular}

APPENDIX (continued).

\begin{tabular}{|c|c|c|c|c|}
\hline $\begin{array}{l}\text { Core, section, } \\
\text { interval }(\mathrm{cm})\end{array}$ & $\begin{array}{l}\text { Depth } \\
\text { (mbsf) }\end{array}$ & $\frac{\mathrm{CaCO}_{3}}{(\%)}$ & $\begin{array}{l}\text { Opal } \\
(\%)\end{array}$ & $\begin{array}{l}\text { Other } \\
(\%)\end{array}$ \\
\hline $5 \mathrm{H}-6,100-102$ & 44.21 & $20.10^{\prime}$ & & \\
\hline $5 \mathrm{H}-6,103-104$ & 44.23 & 21.97 & 52.86 & 25.16 \\
\hline $5 \mathrm{H}-6,110-112$ & 44.31 & 21.55 & & \\
\hline $5 \mathrm{H}-6,131-132$ & 44.51 & 24.44 & 52.74 & 22.81 \\
\hline $5 \mathrm{H}-6,140-142$ & 44.61 & 22.83 & & \\
\hline $5 \mathrm{H}-6,145-149$ & 44.65 & 25.75 & 53.03 & 21.21 \\
\hline $6 \mathrm{H}-1,15-16$ & 45.35 & 51.70 & 27.54 & 20.75 \\
\hline $6 \mathrm{H}-1,29-21$ & 45.40 & 52.25 & & \\
\hline $6 \mathrm{H}-1,45-46$ & 45.65 & 46.35 & 32.66 & 20.98 \\
\hline $6 \mathrm{H}-1,54-55$ & 45.75 & 43.71 & & \\
\hline $6 \mathrm{H}-1,68-72$ & 45.90 & 56.17 & & \\
\hline $6 \mathrm{H}-1,75-76$ & 45.95 & 50.98 & 27.18 & 21.83 \\
\hline $6 \mathrm{H}-1,84-86$ & 46.06 & 48.25 & & \\
\hline $6 \mathrm{H}-1,100-102$ & 46.21 & 48.04 & & \\
\hline $6 \mathrm{H}-1,103-104$ & 46.23 & 47.18 & 31.23 & 21.58 \\
\hline $6 \mathrm{H}-1,105-107$ & 46.26 & 47.92 & & \\
\hline $6 \mathrm{H}-1,127-128$ & 46.47 & 45.61 & 31.40 & 22.99 \\
\hline $6 \mathrm{H}-1,140-142$ & 46.61 & 46.08 & & \\
\hline $6 \mathrm{H}-1,145-149$ & 46.65 & 44.43 & 32.92 & 22.64 \\
\hline $6 \mathrm{H}-2,19-21$ & 46.90 & 51.00 & & \\
\hline $6 \mathrm{H}-2,70-71$ & 47.40 & 56.93 & 24.20 & 18.86 \\
\hline $6 \mathrm{H}-2,84-86$ & 47.55 & 49.00 & & \\
\hline $6 \mathrm{H}-2,105-107$ & 47.76 & 47.50 & & \\
\hline $6 \mathrm{H}-2,120-124$ & 47.92 & 46.33 & & \\
\hline $6 \mathrm{H}-2,140-142$ & 48.11 & 65.67 & & \\
\hline $6 \mathrm{H}-2,145-149$ & 48.15 & 64.10 & 18.91 & 16.98 \\
\hline $6 \mathrm{H}-3,0-5$ & 48.21 & 62.30 & 22.07 & 15.62 \\
\hline $6 \mathrm{H}-3,15-16$ & 48.35 & 64.02 & 21.90 & 14.07 \\
\hline $6 \mathrm{H}-3,19-21$ & 48.40 & 58.96 & & \\
\hline $6 \mathrm{H}-3,28-32$ & 48.50 & 65.92 & & \\
\hline $6 \mathrm{H}-3,45-46$ & 48.65 & 51.04 & 31.53 & 17.42 \\
\hline $6 \mathrm{H}-3,54-56$ & 48.75 & 51.75 & & \\
\hline $6 \mathrm{H}-3,75-76$ & 48.95 & 34.15 & 47.07 & 18.77 \\
\hline $6 \mathrm{H}-3,80-82$ & 49.01 & 38.75 & & \\
\hline $6 \mathrm{H}-3,84-86$ & 49.05 & 25.67 & & \\
\hline $6 \mathrm{H}-3,100-102$ & 49.21 & 30.36 & & \\
\hline $6 \mathrm{H}-3,105-107$ & 49.26 & 25.87 & & \\
\hline $6 \mathrm{H}-3,109-110$ & 49.29 & 32.10 & 50.84 & 17.05 \\
\hline $6 \mathrm{H}-3,145-150$ & 49.66 & 30.04 & 51.20 & 18.76 \\
\hline $6 \mathrm{H}-4,15-16$ & 49.85 & 42.40 & 47.15 & 10.44 \\
\hline $6 \mathrm{H}-4,19-21$ & 49.90 & 23.25 & & \\
\hline $6 \mathrm{H}-4,47-48$ & 50.17 & 29.43 & 53.12 & 17.45 \\
\hline $6 \mathrm{H}-4,54-56$ & 50.25 & 27.58 & & \\
\hline $6 \mathrm{H}-4,75-76$ & 50.45 & 27.83 & 52.14 & 20.02 \\
\hline $6 \mathrm{H}-4,85-86$ & 50.55 & 29.92 & & \\
\hline $6 \mathrm{H}-4,100-102$ & 50.71 & 28.77 & & \\
\hline $6 \mathrm{H}-4,105-107$ & 50.76 & 19.50 & & \\
\hline $6 \mathrm{H}-4,109-110$ & 50.79 & 27.92 & 50.16 & 21.91 \\
\hline $6 \mathrm{H}-4,120-124$ & 50.92 & 40.75 & & \\
\hline $6 \mathrm{H}-4,135-136$ & 51.05 & 38.04 & 38.18 & 23.77 \\
\hline $6 \mathrm{H}-4,140-142$ & 51.11 & 34.92 & & \\
\hline $6 \mathrm{H}-4,145-149$ & 51.15 & 18.28 & 52.09 & 29.62 \\
\hline $6 \mathrm{H}-5,15-16$ & 51.35 & 76.76 & 20.42 & 5.74 \\
\hline $6 \mathrm{H}-5,19-21$ & 51.40 & 53.00 & & \\
\hline $6 \mathrm{H}-5,45-46$ & 51.65 & 68.43 & 15.47 & 16.09 \\
\hline $6 \mathrm{H}-5,50-52$ & 51.71 & 57.71 & & \\
\hline $6 \mathrm{H}-5,54-56$ & 51.75 & 58.42 & & \\
\hline $6 \mathrm{H}-5,75-76$ & 51.95 & 44.08 & 35.66 & 20.25 \\
\hline $6 \mathrm{H}-5,97-98$ & 52.17 & 9.81 & 56.52 & 33.66 \\
\hline $6 \mathrm{H}-5,100-102$ & 52.21 & 9.09 & & \\
\hline $6 \mathrm{H}-5,105-107$ & 52.26 & 8.17 & & \\
\hline $6 \mathrm{H}-5,120-124$ & 52.42 & 19.58 & & \\
\hline $6 \mathrm{H}-5,137-138$ & 52.57 & 25.21 & 52.27 & 22.51 \\
\hline $6 \mathrm{H}-5,140-142$ & 52.61 & 29.33 & & \\
\hline $6 \mathrm{H}-5,145-149$ & 52.65 & 44.59 & 30.62 & 24.78 \\
\hline $6 \mathrm{H}-6,15-16$ & 52.85 & 46.68 & 32.61 & 20.70 \\
\hline $6 \mathrm{H}-6,19-21$ & 52.90 & 38.17 & & \\
\hline $6 \mathrm{H}-6,45-46$ & 53.15 & 50.39 & 28.46 & 21.14 \\
\hline $6 \mathrm{H}-6,54-56$ & 53.25 & 36.25 & & \\
\hline $6 \mathrm{H}-6,75-76$ & 53.45 & 42.97 & 31.25 & 25.77 \\
\hline $6 \mathrm{H}-6,84-86$ & 53.55 & 45.63 & & \\
\hline $6 \mathrm{H}-6,100-102$ & 53.71 & 47.96 & & \\
\hline $6 \mathrm{H}-6,104-105$ & 53.74 & 43.81 & 34.11 & 22.07 \\
\hline $6 \mathrm{H}-6,105-107$ & 53.76 & 46.33 & & \\
\hline $6 \mathrm{H}-6,137-138$ & 54.07 & 49.67 & 31.88 & 18.44 \\
\hline $6 \mathrm{H}-6,140-142$ & 54.11 & 45.08 & & \\
\hline $6 \mathrm{H}-6,145-149$ & 54.15 & 49.06 & 30.43 & 20.50 \\
\hline
\end{tabular}


APPENDIX (continued).

\begin{tabular}{|c|c|c|c|c|}
\hline $\begin{array}{l}\text { Core, section, } \\
\text { interval }(\mathrm{cm})\end{array}$ & $\begin{array}{l}\text { Depth } \\
\text { (mbsf) }\end{array}$ & $\begin{array}{c}\mathrm{CaCO}_{3} \\
(\%)\end{array}$ & $\begin{array}{l}\text { Opal } \\
(\%)\end{array}$ & $\begin{array}{l}\text { Other } \\
(\%)\end{array}$ \\
\hline $6 \mathrm{H}-7,15-16$ & 54.35 & 50.56 & 30.24 & 19.19 \\
\hline $6 \mathrm{H}-7,19-21$ & 54.40 & 42.67 & & \\
\hline $6 \mathrm{H}-7,36-37$ & 54.56 & 46.66 & 33.13 & 20.20 \\
\hline $6 \mathrm{H}-7,45-46$ & 54.65 & 52.15 & 28.06 & 19.78 \\
\hline $6 \mathrm{H}-7,54-56$ & 54.75 & 55.58 & & \\
\hline $7 \mathrm{H}-1,15-16$ & 54.85 & 49.27 & 31.10 & 19.62 \\
\hline $6 \mathrm{H}-7,66-67$ & 54.86 & 51.28 & 28.53 & 20.18 \\
\hline $7 \mathrm{H}-1,45-46$ & 55.15 & 29.55 & 57.74 & 12.71 \\
\hline $7 \mathrm{H}-1,59-61$ & 55.30 & 17.42 & & \\
\hline $7 \mathrm{H}-1,75-76$ & 55.45 & 19.93 & 61.90 & 18.16 \\
\hline $7 \mathrm{H}-1,90-92$ & 55.61 & 14.17 & & \\
\hline $7 \mathrm{H}-1,104-105$ & 55.74 & 16.48 & 60.94 & 22.57 \\
\hline $7 \mathrm{H}-1,108-110$ & 55.79 & 17.68 & & \\
\hline $7 \mathrm{H}-1,119-121$ & 55.90 & 20.92 & & \\
\hline $7 \mathrm{H}-1,133-134$ & 56.03 & 24.28 & 55.89 & 19.82 \\
\hline $7 \mathrm{H}-1,133-134$ & 56.04 & 24.28 & & \\
\hline $7 \mathrm{H}-1,139-143$ & 56.09 & 29.26 & 54.75 & 15.98 \\
\hline $7 \mathrm{H}-2,10-12$ & 56.31 & 35.42 & & \\
\hline $7 \mathrm{H}-2,15-16$ & 56.35 & 45.42 & 31.77 & 22.80 \\
\hline $7 \mathrm{H}-2,29-31$ & 56.50 & 36.08 & & \\
\hline $7 \mathrm{H}-2,43-47$ & 56.63 & 54.56 & 23.17 & 22.26 \\
\hline $7 \mathrm{H}-2,56-61$ & 56.80 & 35.92 & & \\
\hline $7 \mathrm{H}-2,70-74$ & 56.92 & 51.83 & & \\
\hline $7 \mathrm{H}-2,77-78$ & 56.97 & 50.22 & 30.12 & 19.65 \\
\hline $7 \mathrm{H}-2,102-104$ & 57.23 & 53.04 & & \\
\hline $7 \mathrm{H}-2,106-107$ & 57.26 & 50.08 & 26.44 & 23.47 \\
\hline $7 \mathrm{H}-2,119-121$ & 57.40 & 20.33 & & \\
\hline $7 \mathrm{H}-2,134-135$ & 57.54 & 55.09 & 24.69 & 20.21 \\
\hline $7 \mathrm{H}-3,0-5$ & 57.71 & 55.40 & 25.88 & 18.71 \\
\hline $7 \mathrm{H}-3,10-12$ & 57.81 & 67.17 & & \\
\hline $7 \mathrm{H}-3,26-27$ & 57.96 & 72.34 & 12.42 & 15.23 \\
\hline $7 \mathrm{H}-3,29-31$ & 58.00 & 71.92 & & \\
\hline $7 \mathrm{H}-3,43-47$ & 58.13 & 54.13 & 28.03 & 17.83 \\
\hline $7 \mathrm{H}-3,56-61$ & 58.30 & 41.25 & & \\
\hline $7 \mathrm{H}-3,75-76$ & 58.45 & 31.19 & 55.45 & 13.35 \\
\hline $7 \mathrm{H}-3,90-92$ & 58.61 & 20.17 & & \\
\hline $7 \mathrm{H}-3,102-104$ & 58.73 & 19.27 & & \\
\hline $7 \mathrm{H}-3,106-107$ & 58.76 & 20.22 & 56.28 & 23.49 \\
\hline $7 \mathrm{H}-3,109-113$ & 58.81 & 25.58 & & \\
\hline $7 \mathrm{H}-3,119-121$ & 58.90 & 19.25 & & \\
\hline $7 \mathrm{H}-3,133-134$ & 59.03 & 33.55 & 46.04 & 20.40 \\
\hline $7 \mathrm{H}-4,15-16$ & 59.35 & 48.76 & 25.19 & 26.04 \\
\hline $7 \mathrm{H}-4,48-52$ & 59.68 & 39.92 & 36.86 & 23.21 \\
\hline $7 \mathrm{H}-4,59-61$ & 59.80 & 60.92 & & \\
\hline $7 \mathrm{H}-4,66-68$ & 59.87 & 40.50 & & \\
\hline $7 \mathrm{H}-4,77-78$ & 59.97 & 39.50 & 38.25 & 22.24 \\
\hline $7 \mathrm{H}-4,90-92$ & 60.11 & 41.33 & & \\
\hline $7 \mathrm{H}-4,102-104$ & 60.23 & 51.79 & & \\
\hline $7 \mathrm{H}-4,106-107$ & 60.26 & 57.53 & 26.43 & 16.03 \\
\hline $7 \mathrm{H}-4,119-121$ & 60.40 & 43.67 & & \\
\hline $7 \mathrm{H}-4,133-134$ & 60.53 & 43.00 & 28.53 & 28.46 \\
\hline $7 \mathrm{H}-5,10-12$ & 60.81 & 42.75 & & \\
\hline $7 \mathrm{H}-5,15-16$ & 60.85 & 33.30 & 30.65 & 36.04 \\
\hline $7 \mathrm{H}-5,18-22$ & 60.90 & 49.54 & & \\
\hline $7 \mathrm{H}-5,29-30$ & 61.00 & 45.92 & & \\
\hline $7 \mathrm{H}-5,43-47$ & 61.13 & 58.14 & 23.16 & 18.69 \\
\hline $7 \mathrm{H}-5,59-61$ & 61.30 & 52.00 & & \\
\hline $7 \mathrm{H}-5,77-78$ & 61.47 & 37.69 & 22.66 & 39.64 \\
\hline $7 \mathrm{H}-5,90-92$ & 61.61 & 23.50 & & \\
\hline $7 \mathrm{H}-5,102-104$ & 61.73 & 25.85 & & \\
\hline $7 \mathrm{H}-5,106-107$ & 61.76 & 25.46 & 44.06 & 30.47 \\
\hline $7 \mathrm{H}-5,119-121$ & 61.90 & 29.00 & & \\
\hline $7 \mathrm{H}-5,144-145$ & 62.14 & 24.32 & 56.76 & 18.91 \\
\hline $7 \mathrm{H}-6,10-12$ & 62.31 & 35.83 & & \\
\hline $7 \mathrm{H}-6,13-14$ & 62.33 & 21.81 & 57.32 & 20.86 \\
\hline $7 \mathrm{H}-6,29-31$ & 62.50 & 22.42 & & \\
\hline $7 \mathrm{H}-6,40-42$ & 62.61 & 15.60 & & \\
\hline $7 H-6,43-47$ & 62.63 & 33.68 & 54.11 & 12.20 \\
\hline $7 H-6,59-61$ & 62.80 & 19.92 & & \\
\hline $7 \mathrm{H}-6,67-69$ & 62.88 & 20.00 & & \\
\hline $7 \mathrm{H}-6,70-71$ & 62.90 & 23.38 & 57.18 & 19.50 \\
\hline $7 \mathrm{H}-6,90-92$ & 63.11 & 18.83 & & \\
\hline $7 \mathrm{H}-6,103-104$ & 63.23 & 22.28 & 59.83 & 17.88 \\
\hline $8 \mathrm{H}-1,9-13$ & 64.31 & 51.67 & & \\
\hline $8 \mathrm{H}-1,17-18$ & 64.37 & 49.15 & 29.80 & 21.04 \\
\hline $8 \mathrm{H}-1,29-31$ & 64.50 & 53.25 & & \\
\hline $8 H-1,45-46$ & 64.65 & 53.60 & 30.40 & 15.99 \\
\hline
\end{tabular}

APPENDIX (continued).

\begin{tabular}{|c|c|c|c|c|}
\hline $\begin{array}{l}\text { Core, section, } \\
\text { interval }(\mathrm{cm})\end{array}$ & $\begin{array}{l}\text { Depth } \\
\text { (mbsf) }\end{array}$ & $\underset{(\%)}{\mathrm{CaCO}_{3}}$ & $\begin{array}{l}\text { Opal } \\
(\%)\end{array}$ & $\begin{array}{l}\text { Other } \\
(\%)\end{array}$ \\
\hline $8 H-1,60-64$ & 64.80 & 55.11 & 26.37 & 18.51 \\
\hline $8 \mathrm{H}-1,80-82$ & 65.01 & 54.75 & & \\
\hline $8 \mathrm{H}-1,100-102$ & 65.21 & 64.05 & & \\
\hline $8 \mathrm{H}-1,105-106$ & 65.25 & 68.97 & 18.61 & 12.41 \\
\hline $8 \mathrm{H}-1,110-112$ & 65.31 & 69.08 & & \\
\hline $8 \mathrm{H}-1,136-137$ & 65.56 & 7.41 & 65.30 & 27.28 \\
\hline $8 \mathrm{H}-1,139-141$ & 65.60 & 8.25 & & \\
\hline $8 \mathrm{H}-2,15-16$ & 65.85 & 9.59 & 69.54 & 20.86 \\
\hline $8 H-2,29-31$ & 66.00 & 8.67 & & \\
\hline $8 \mathrm{H}-2,45-46$ & 66.15 & 14.28 & 62.21 & 23.50 \\
\hline $8 \mathrm{H}-2,50-52$ & 66.21 & 13.17 & & \\
\hline $8 \mathrm{H}-2,60-64$ & 66.30 & 18.02 & 61.14 & 20.83 \\
\hline $8 \mathrm{H}-2,69-73$ & 66.41 & 21.08 & & \\
\hline $8 \mathrm{H}-2,76-77$ & 66.46 & 15.80 & 59.51 & 24.68 \\
\hline $8 \mathrm{H}-2,80-82$ & 66.51 & 13.58 & & \\
\hline $8 \mathrm{H}-2,106-107$ & 66.76 & 42.88 & 32.15 & 24.96 \\
\hline $8 \mathrm{H}-2,110-112$ & 66.81 & 41.50 & & \\
\hline $8 \mathrm{H}-2,137-138$ & 67.07 & 41.92 & 34.52 & 23.55 \\
\hline $8 \mathrm{H}-3,0-5$ & 67.21 & 56.70 & 23.92 & 19.37 \\
\hline $8 \mathrm{H}-3,30-32$ & 67.51 & 61.33 & & \\
\hline $8 \mathrm{H}-3,45-46$ & 67.65 & 62.48 & 16.78 & 20.73 \\
\hline $8 \mathrm{H}-3,47-49$ & 67.68 & 61.08 & & \\
\hline $8 \mathrm{H}-3,52-54$ & 67.73 & 60.72 & & \\
\hline $8 \mathrm{H}-3,60-64$ & 67.80 & 38.17 & 37.93 & 23.89 \\
\hline $8 \mathrm{H}-3,69-73$ & 67.91 & 7.42 & & \\
\hline $8 \mathrm{H}-3,80-83$ & 68.01 & 5.50 & & \\
\hline $8 \mathrm{H}-3,100-102$ & 68.21 & 10.01 & & \\
\hline $8 \mathrm{H}-3,105-106$ & 68.25 & 15.51 & 62.45 & 22.03 \\
\hline $8 \mathrm{H}-3,110-113$ & 68.31 & 11.25 & & \\
\hline $8 \mathrm{H}-3,137-138$ & 68.57 & 30.99 & 38.73 & 30.27 \\
\hline $8 \mathrm{H}-3,139-141$ & 68.60 & 32.75 & & \\
\hline $8 \mathrm{H}-4,9-13$ & 68.81 & 9.58 & & \\
\hline $8 \mathrm{H}-4,16-17$ & 68.86 & 13.83 & 56.63 & 29.53 \\
\hline $8 \mathrm{H}-4,30-32$ & 69.01 & 25.58 & & \\
\hline $8 \mathrm{H}-4,47-48$ & 69.17 & 45.97 & 32.39 & 21.63 \\
\hline $8 \mathrm{H}-4,50-52$ & 69.21 & 36.92 & & \\
\hline $8 \mathrm{H}-4,60-64$ & 69.30 & 45.33 & 31.41 & 23.27 \\
\hline $8 \mathrm{H}-4,80-82$ & 69.51 & 23.67 & & \\
\hline $8 \mathrm{H}-4,90-92$ & 69.61 & 26.44 & & \\
\hline $8 \mathrm{H}-4,107-108$ & 69.77 & 32.75 & 43.34 & 23.90 \\
\hline $8 \mathrm{H}-4,110-112$ & 69.81 & 26.25 & & \\
\hline $8 \mathrm{H}-4,136-137$ & 70.06 & 24.79 & 46.93 & 28.27 \\
\hline $8 \mathrm{H}-4,139-141$ & 70.10 & 18.75 & & \\
\hline $8 \mathrm{H}-5,16-17$ & 70.36 & 25.36 & 48.67 & 25.97 \\
\hline $8 \mathrm{H}-5,30-32$ & 70.51 & 21.75 & & \\
\hline $8 \mathrm{H}-5,40-42$ & 70.61 & 27.36 & & \\
\hline $8 \mathrm{H}-5,45-46$ & 70.65 & 27.07 & 50.14 & 22.78 \\
\hline $8 \mathrm{H}-5,50-52$ & 70.71 & 23.08 & & \\
\hline $8 \mathrm{H}-5,60-64$ & 70.83 & 35.00 & 37.65 & 27.34 \\
\hline $8 \mathrm{H}-5,69-73$ & 70.91 & 22.67 & & \\
\hline $8 \mathrm{H}-5,80-82$ & 71.01 & 19.67 & & \\
\hline $8 \mathrm{H}-5,89-90$ & 71.09 & 23.46 & 49.94 & 26.59 \\
\hline $8 \mathrm{H}-5,106-107$ & 71.26 & 27.51 & 46.42 & 26.06 \\
\hline $8 \mathrm{H}-5,110-112$ & 71.31 & 24.33 & & \\
\hline $8 \mathrm{H}-5,135-136$ & 71.55 & 24.35 & 44.84 & 30.80 \\
\hline $8 \mathrm{H}-5,139-141$ & 71.60 & 24.67 & & \\
\hline $8 \mathrm{H}-6,15-16$ & 71.85 & 36.93 & 35.42 & 27.64 \\
\hline $8 \mathrm{H}-6,30-32$ & 72.01 & 31.25 & & \\
\hline $8 H-6,50-52$ & 72.21 & 36.50 & & \\
\hline $8 \mathrm{H}-6,55-59$ & 72.26 & 37.87 & 39.40 & 22.72 \\
\hline $8 H-6,60-62$ & 72.31 & 37.53 & & \\
\hline $8 \mathrm{H}-6,69-73$ & 72.41 & 44.92 & & \\
\hline $8 \mathrm{H}-6,76-77$ & 72.46 & 46.03 & 28.80 & 25.16 \\
\hline $8 \mathrm{H}-6,80-82$ & 72.51 & 37.83 & & \\
\hline $8 \mathrm{H}-6,105-106$ & 72.75 & 46.24 & 38.11 & 15.65 \\
\hline $8 \mathrm{H}-6,110-112$ & 72.81 & 27.92 & & \\
\hline $9 \mathrm{H}-1,29-30$ & 73.99 & 43.91 & 36.04 & 20.04 \\
\hline $9 \mathrm{H}-1,50-52$ & 74.21 & 55.00 & & \\
\hline $9 \mathrm{H}-1,58-62$ & 74.28 & 45.76 & 32.89 & 21.35 \\
\hline $9 \mathrm{H}-1,68-72$ & 74.40 & 42.75 & & \\
\hline $9 \mathrm{H}-1,74-75$ & 74.44 & 46.98 & 31.01 & 22.00 \\
\hline $9 \mathrm{H}-1,80-82$ & 74.51 & 41.67 & & \\
\hline $9 \mathrm{H}-1,100-102$ & 74.71 & 50.54 & & \\
\hline $9 \mathrm{H}-1,105-106$ & 74.75 & 53.38 & 24.40 & 22.21 \\
\hline $9 \mathrm{H}-1,110-112$ & 74.81 & 55.92 & & \\
\hline $9 \mathrm{H}-1,135-136$ & 75.05 & 50.04 & 29.09 & 20.86 \\
\hline $9 \mathrm{H}-1,140-142$ & 75.11 & 44.25 & & \\
\hline
\end{tabular}


APPENDIX (continued).

\begin{tabular}{|c|c|c|c|c|}
\hline $\begin{array}{l}\text { Core, section, } \\
\text { interval }(\mathrm{cm})\end{array}$ & $\begin{array}{l}\text { Depth } \\
\text { (mbsf) }\end{array}$ & $\begin{array}{c}\mathrm{CaCO}_{3} \\
(\%)\end{array}$ & $\begin{array}{c}\text { Opal } \\
(\%)\end{array}$ & $\begin{array}{l}\text { Other } \\
(\%)\end{array}$ \\
\hline $9 \mathrm{H}-2,8-12$ & 75.30 & 40.75 & & \\
\hline $9 \mathrm{H}-2,18-19$ & 75.38 & 48.51 & 26.71 & 24.77 \\
\hline $9 \mathrm{H}-2,20-22$ & 75.41 & 45.83 & & \\
\hline $9 \mathrm{H}-2,45-46$ & 75.65 & 72.46 & 15.72 & 10.71 \\
\hline $9 \mathrm{H}-2,50-52$ & 75.71 & 55.58 & & \\
\hline $9 \mathrm{H}-2,58-62$ & 75.78 & 62.90 & 23.41 & 13.68 \\
\hline $9 \mathrm{H}-2,80-82$ & 76.01 & 23.33 & & \\
\hline $9 \mathrm{H}-2,100-102$ & 76.21 & 31.36 & & \\
\hline $9 \mathrm{H}-2,105-106$ & 76.25 & 31.53 & 49.19 & 19.27 \\
\hline $9 \mathrm{H}-2,110-112$ & 76.31 & 31.00 & & \\
\hline $9 \mathrm{H}-2,118-122$ & 76.40 & 33.67 & & \\
\hline $9 \mathrm{H}-2,135-136$ & 76.55 & 36.63 & 42.71 & 20.65 \\
\hline $9 \mathrm{H}-2,140-142$ & 76.61 & 31.75 & & \\
\hline $9 \mathrm{H}-3,0-5$ & 76.70 & 38.91 & 41.35 & 19.73 \\
\hline $9 \mathrm{H}-3,20-22$ & 76.91 & 31.92 & & \\
\hline $9 \mathrm{H}-3,50-52$ & 77.21 & 44.50 & & \\
\hline $9 \mathrm{H}-3,58-62$ & 77.28 & 54.77 & 29.12 & 16.10 \\
\hline $9 \mathrm{H}-3,75-76$ & 77.45 & 45.49 & 30.80 & 23.70 \\
\hline $9 \mathrm{H}-3,100-102$ & 77.71 & 54.54 & & \\
\hline $9 \mathrm{H}-3,105-106$ & 77.75 & 54.1 & 25.72 & 20.08 \\
\hline $9 \mathrm{H}-3,110-112$ & 77.81 & 52.42 & & \\
\hline $9 \mathrm{H}-3,135-136$ & 78.05 & 43.74 & 34.54 & 21.71 \\
\hline $9 \mathrm{H}-3,140-142$ & 78.11 & 44.70 & & \\
\hline $9 \mathrm{H}-4,8-12$ & 78.30 & 45.30 & & \\
\hline $9 \mathrm{H}-4,18-19$ & 78.38 & 50.46 & 33.22 & 16.31 \\
\hline $9 \mathrm{H}-4,20-22$ & 78.41 & 36.92 & & \\
\hline $9 \mathrm{H}-4,45-46$ & 78.65 & 61.86 & 23.02 & 15.11 \\
\hline $9 \mathrm{H}-4,50-52$ & 78.71 & 45.92 & & \\
\hline $9 \mathrm{H}-4,58-62$ & 78.78 & 70.73 & 15.92 & 13.34 \\
\hline $9 \mathrm{H}-4,80-82$ & 79.01 & 53.05 & & \\
\hline $9 \mathrm{H}-4,100-102$ & 79.21 & 64.80 & & \\
\hline $9 \mathrm{H}-4,104-105$ & 79.24 & 63.86 & 22.20 & 13.93 \\
\hline $9 \mathrm{H}-4,110-112$ & 79.31 & 62.58 & & \\
\hline $9 \mathrm{H}-4,145-150$ & 79.66 & 53.77 & 30.94 & 15.28 \\
\hline $9 \mathrm{H}-5,8-12$ & 79.80 & 39.30 & & \\
\hline $9 \mathrm{H}-5,15-16$ & 79.85 & 43.60 & 35.05 & 21.34 \\
\hline $9 \mathrm{H}-5,20-22$ & 79.91 & 44.83 & & \\
\hline $9 \mathrm{H}-5,50-52$ & 80.21 & 37.50 & & \\
\hline $9 \mathrm{H}-5,58-62$ & 80.28 & 57.95 & 20.02 & 21.10 \\
\hline $9 \mathrm{H}-5,76-77$ & 80.46 & 19.05 & 50.21 & 30.73 \\
\hline $9 \mathrm{H}-5,80-82$ & 80.51 & 24.33 & & \\
\hline $9 \mathrm{H}-5,100-102$ & 80.71 & 10.26 & & \\
\hline $9 \mathrm{H}-5,105-106$ & 80.75 & 13.68 & 54.48 & 31.83 \\
\hline $9 \mathrm{H}-5,110-112$ & 80.81 & 9.50 & & \\
\hline $9 H-5,135-136$ & 81.05 & 10.54 & 56.97 & 32.48 \\
\hline $9 \mathrm{H}-5,140-142$ & 81.11 & 19.97 & & \\
\hline $9 \mathrm{H}-6,13-14$ & 81.33 & 9.52 & 57.32 & 33.15 \\
\hline $9 \mathrm{H}-6,20-22$ & 81.41 & 8.08 & & \\
\hline $9 \mathrm{H}-6,45-46$ & 81.65 & 12.79 & 52.70 & 34.50 \\
\hline $9 \mathrm{H}-6,50-52$ & 81.71 & 13.83 & & \\
\hline $9 \mathrm{H}-6,58-62$ & 81.78 & 11.40 & 53.30 & 35.29 \\
\hline $9 \mathrm{H}-6,80-82$ & 82.01 & 9.67 & & \\
\hline $9 \mathrm{H}-6,100-102$ & 82.21 & 10.17 & & \\
\hline $9 H-6,105-106$ & 82.25 & 18.85 & 53.33 & 27.81 \\
\hline $9 H-6,110-112$ & 82.31 & 9.58 & & \\
\hline $9 H-6,118-122$ & 82.40 & 13.60 & & \\
\hline $9 \mathrm{H}-6,135-136$ & 82.55 & 12.35 & 53.21 & 34.43 \\
\hline $9 \mathrm{H}-6,140-142$ & 82.61 & 11.67 & & \\
\hline $9 \mathrm{H}-7,20-22$ & 82.91 & 13.08 & & \\
\hline $10 \mathrm{H}-1,17-18$ & 83.37 & 11.96 & 58.99 & 29.04 \\
\hline $10 \mathrm{H}-1,19-21$ & 83.40 & 7.75 & & \\
\hline $10 \mathrm{H}-1,46-47$ & 83.66 & 11.07 & 58.91 & 30.01 \\
\hline $10 \mathrm{H}-1,50-52$ & 83.71 & 10.40 & & \\
\hline $10 \mathrm{H}-1,75-76$ & 83.95 & 13.25 & 59.37 & 27.37 \\
\hline $10 \mathrm{H}-1,79-81$ & 84.00 & 6.25 & & \\
\hline $10 \mathrm{H}-1,99-100$ & 84.20 & 11.18 & & \\
\hline $10 \mathrm{H}-1,105-106$ & 84.25 & 12.86 & 56.01 & 31.12 \\
\hline $10 \mathrm{H}-1,109-111$ & 84.30 & 7.50 & & \\
\hline $10 \mathrm{H}-1,138-142$ & 84.58 & 16.76 & 53.30 & 29.93 \\
\hline $10 \mathrm{H}-2,16-17$ & 84.86 & 14.97 & 51.67 & 33.35 \\
\hline $10 \mathrm{H}-2,19-21$ & 84.90 & 15.75 & & \\
\hline $10 \mathrm{H}-2,45-46$ & 85.15 & 55.40 & 20.96 & 23.63 \\
\hline $10 \mathrm{H}-2,50-52$ & 85.21 & 54.67 & & \\
\hline $10 \mathrm{H}-2,75-76$ & 85.45 & 64.26 & 18.50 & 17.24 \\
\hline $10 \mathrm{H}-2,79-81$ & 85.50 & 52.25 & & \\
\hline $10 \mathrm{H}-2,99-101$ & 85.70 & 51.79 & & \\
\hline $10 \mathrm{H}-2,105-106$ & 85.75 & 48.32 & 29.35 & 22.32 \\
\hline
\end{tabular}

APPENDIX (continued).

\begin{tabular}{|c|c|c|c|c|}
\hline $\begin{array}{l}\text { Core, section, } \\
\text { interval }(\mathrm{cm})\end{array}$ & $\begin{array}{l}\text { Depth } \\
\text { (mbsf) }\end{array}$ & $\begin{array}{c}\mathrm{CaCO}_{3} \\
(\%)\end{array}$ & $\begin{array}{c}\text { Opal } \\
(\%)\end{array}$ & $\begin{array}{l}\text { Other } \\
(\%)\end{array}$ \\
\hline $10 \mathrm{H}-2,109-111$ & 85.80 & 47.17 & & \\
\hline $10 \mathrm{H}-2,118-122$ & 85.90 & 28.80 & & \\
\hline $10 \mathrm{H}-2,135-136$ & 86.05 & 23.32 & 49.10 & 27.57 \\
\hline $10 \mathrm{H}-2,138-142$ & 86.08 & 16.01 & 50.06 & 33.92 \\
\hline $10 \mathrm{H}-3,0-5$ & 86.20 & 22.34 & 44.79 & 32.86 \\
\hline $10 \mathrm{H}-3,20-22$ & 86.41 & 15.75 & & \\
\hline $10 \mathrm{H}-3,45-46$ & 86.65 & 20.16 & 51.38 & 28.45 \\
\hline $10 \mathrm{H}-3,50-52$ & 86.71 & 16.67 & & \\
\hline $10 \mathrm{H}-3,75-76$ & 86.95 & 21.29 & 44.07 & 34.63 \\
\hline $10 \mathrm{H}-3,79-81$ & 87.00 & 21.00 & & \\
\hline $10 \mathrm{H}-3,99-101$ & 87.20 & 26.94 & & \\
\hline $10 \mathrm{H}-3,105-106$ & 87.25 & 25.50 & 42.53 & 31.96 \\
\hline $10 \mathrm{H}-3,109-111$ & 87.30 & 23.25 & & \\
\hline $10 \mathrm{H}-3,118-122$ & 87.40 & 25.50 & & \\
\hline $10 \mathrm{H}-3,138-142$ & 87.58 & 24.98 & 44.14 & 30.87 \\
\hline $10 \mathrm{H}-4,17-18$ & 87.87 & 26.50 & 43.86 & 29.63 \\
\hline $10 \mathrm{H}-4,19-21$ & 87.90 & 20.92 & & \\
\hline $10 \mathrm{H}-4,45-46$ & 88.15 & 26.03 & 42.67 & 31.29 \\
\hline $10 \mathrm{H}-4,50-52$ & 88.21 & 26.00 & & \\
\hline $10 \mathrm{H}-4,75-76$ & 88.45 & 26.77 & 44.37 & 28.86 \\
\hline $10 \mathrm{H}-4,79-81$ & 88.50 & 22.00 & & \\
\hline $10 \mathrm{H}-4,103-104$ & 88.73 & 25.02 & 45.98 & 29.00 \\
\hline $10 \mathrm{H}-4,105-107$ & 88.76 & 23.44 & & \\
\hline $10 \mathrm{H}-4,109-111$ & 88.80 & 21.17 & & \\
\hline $10 \mathrm{H}-4,138-142$ & 89.08 & 20.37 & 48.61 & 31.01 \\
\hline $10 \mathrm{H}-5,15-16$ & 89.35 & 14.56 & 54.77 & 30.66 \\
\hline $10 \mathrm{H}-5,19-21$ & 89.40 & 9.58 & & \\
\hline $10 \mathrm{H}-5,45-46$ & 89.65 & 9.81 & 57.00 & 33.19 \\
\hline $10 \mathrm{H}-5,50-52$ & 89.71 & 7.83 & & \\
\hline $10 \mathrm{H}-5,76-77$ & 89.96 & 7.11 & 58.86 & 34.02 \\
\hline $10 \mathrm{H}-5,79-81$ & 90.00 & 5.25 & & \\
\hline $10 \mathrm{H}-5,99-101$ & 90.20 & 4.67 & & \\
\hline $10 \mathrm{H}-5,105-106$ & 90.25 & 7.78 & 57.66 & 34.55 \\
\hline $10 \mathrm{H}-5,109-111$ & 90.30 & 8.00 & & \\
\hline $10 \mathrm{H}-5,138-142$ & 90.58 & 6.97 & 58.86 & 34.16 \\
\hline $10 \mathrm{H}-6,16-17$ & 90.86 & 9.52 & 56.88 & 33.59 \\
\hline $10 \mathrm{H}-6,19-21$ & 90.90 & 7.17 & & \\
\hline $10 \mathrm{H}-6,45-46$ & 91.15 & 10.45 & 57.23 & 32.31 \\
\hline $10 \mathrm{H}-6,50-52$ & 91.21 & 10.80 & & \\
\hline $10 \mathrm{H}-6,76-77$ & 91.45 & 12.79 & 54.24 & 32.96 \\
\hline $10 \mathrm{H}-6,79-81$ & 91.50 & 9.25 & & \\
\hline $10 \mathrm{H}-6,99-101$ & 91.70 & 16.51 & & \\
\hline $10 \mathrm{H}-6,106-107$ & 91.76 & 19.06 & 63.51 & 17.42 \\
\hline $10 \mathrm{H}-6,109-111$ & 91.80 & 18.75 & & \\
\hline $10 \mathrm{H}-6,138-142$ & 92.08 & 33.99 & 50.28 & 15.72 \\
\hline $10 \mathrm{H}-7,10-14$ & 92.32 & 21.70 & & \\
\hline $10 \mathrm{H}-7,15-16$ & 92.35 & 32.93 & 54.43 & 12.63 \\
\hline $10 \mathrm{H}-7,19-21$ & 92.40 & 4.67 & & \\
\hline $10 \mathrm{H}-7,45-47$ & 92.66 & 10.50 & & \\
\hline $10 \mathrm{H}-7,48-49$ & 92.68 & 15.40 & 60.49 & 24.10 \\
\hline $11 \mathrm{H}-1,15-16$ & 92.85 & 24.34 & 51.98 & 23.67 \\
\hline $11 \mathrm{H}-1,20-22$ & 92.91 & 11.67 & & \\
\hline $10 \mathrm{H}-7,75-76$ & 92.95 & 12.14 & 67.63 & 20.22 \\
\hline $10 \mathrm{H}-7,79-81$ & 93.00 & 12.92 & & \\
\hline $11 \mathrm{H}-1,45-46$ & 93.15 & 35.43 & 45.42 & 19.14 \\
\hline $11 \mathrm{H}-1,50-52$ & 93.21 & 26.25 & & \\
\hline $11 \mathrm{H}-1,70-74$ & 93.42 & 30.00 & & \\
\hline $11 \mathrm{H}-1,76-77$ & 93.46 & 35.59 & 44.96 & 19.44 \\
\hline $11 \mathrm{H}-1,80-82$ & 93.51 & 25.00 & & \\
\hline $11 \mathrm{H}-1,89-93$ & 93.59 & 33.21 & 48.39 & 18.39 \\
\hline $11 \mathrm{H}-1,100-102$ & 93.71 & 31.19 & & \\
\hline $11 \mathrm{H}-1,110-112$ & 93.81 & 29.42 & & \\
\hline $11 \mathrm{H}-1,136-137$ & 94.06 & 32.06 & 50.42 & 17.51 \\
\hline $11 \mathrm{H}-1,140-142$ & 94.11 & 35.62 & & \\
\hline $11 \mathrm{H}-2,17-18$ & 94.37 & 32.50 & 48.62 & 18.78 \\
\hline $11 \mathrm{H}-2,20-22$ & 94.41 & 29.67 & & \\
\hline $11 \mathrm{H}-2,46-47$ & 94.66 & 26.19 & 54.15 & 19.65 \\
\hline $11 \mathrm{H}-2,50-52$ & 94.71 & 26.90 & & \\
\hline $11 \mathrm{H}-2,71-72$ & 94.91 & 26.31 & 57.90 & 15.78 \\
\hline $11 \mathrm{H}-2,80-82$ & 95.01 & 20.83 & & \\
\hline $11 \mathrm{H}-2,89-93$ & 95.09 & 24.28 & 60.70 & 15.01 \\
\hline $11 \mathrm{H}-2,110-112$ & 95.31 & 9.67 & & \\
\hline $11 \mathrm{H}-2,120-124$ & 95.42 & 11.80 & & \\
\hline $11 \mathrm{H}-2,135-136$ & 95.55 & 12.77 & 68.32 & 18.90 \\
\hline $11 \mathrm{H}-2,140-142$ & 95.61 & 11.67 & & \\
\hline $11 \mathrm{H}-3,10-14$ & 95.82 & 14.20 & & \\
\hline $11 \mathrm{H}-3,15-16$ & 95.85 & 13.34 & 67.79 & 18.86 \\
\hline
\end{tabular}


APPENDIX (continued).

\begin{tabular}{|c|c|c|c|c|}
\hline $\begin{array}{l}\text { Core, section, } \\
\text { interval }(\mathrm{cm})\end{array}$ & $\begin{array}{l}\text { Depth } \\
\text { (mbsf) }\end{array}$ & $\begin{array}{c}\mathrm{CaCO}_{3} \\
(\%)\end{array}$ & $\begin{array}{c}\text { Opal } \\
(\%)\end{array}$ & $\begin{array}{l}\text { Other } \\
(\%)\end{array}$ \\
\hline $11 \mathrm{H}-3,45-46$ & 96.15 & 17.91 & 65.01 & 17.07 \\
\hline $11 \mathrm{H}-3,50-52$ & 96.21 & 17.60 & & \\
\hline $11 \mathrm{H}-3,77-78$ & 96.47 & 22.21 & 66.79 & 10.99 \\
\hline $11 \mathrm{H}-3,80-82$ & 96.51 & 16.25 & & \\
\hline $11 \mathrm{H}-3,89-93$ & 96.59 & 17.54 & 59.29 & 23.16 \\
\hline $11 \mathrm{H}-3,100-102$ & 96.71 & 17.10 & & \\
\hline $11 \mathrm{H}-3,110-112$ & 96.81 & 16.58 & & \\
\hline $11 \mathrm{H}-3,135-136$ & 97.05 & 17.79 & 67.26 & 14.94 \\
\hline $11 \mathrm{H}-3,140-142$ & 97.11 & 17.08 & & \\
\hline $11 \mathrm{H}-4,16-17$ & 97.36 & 17.79 & 74.19 & 8.02 \\
\hline $11 \mathrm{H}-4,20-22$ & 97.41 & 14.92 & & \\
\hline $11 \mathrm{H}-4,45-46$ & 97.65 & 20.42 & 62.45 & 17.12 \\
\hline $11 \mathrm{H}-4,50-52$ & 97.71 & 29.62 & & \\
\hline $11 \mathrm{H}-4,80-82$ & 98.01 & 31.00 & & \\
\hline $11 \mathrm{H}-4,89-93$ & 98.09 & 51.33 & 32.62 & 16.04 \\
\hline $11 \mathrm{H}-4,109-110$ & 98.29 & 42.34 & 37.51 & 20.14 \\
\hline $11 \mathrm{H}-4,110-112$ & 98.31 & 44.28 & & \\
\hline $11 \mathrm{H}-4,114-116$ & 98.35 & 38.92 & & \\
\hline $11 \mathrm{H}-4,138-139$ & 98.58 & 43.05 & 37.71 & 19.24 \\
\hline $11 \mathrm{H}-4,140-142$ & 98.61 & 43.17 & & \\
\hline $11 \mathrm{H}-5,0-5$ & 98.71 & 41.28 & 29.24 & 29.47 \\
\hline $11 \mathrm{H}-5,10-14$ & 98.82 & 43.40 & & \\
\hline $11 \mathrm{H}-5,20-22$ & 98.91 & 32.58 & & \\
\hline $11 \mathrm{H}-5,46-47$ & 99.16 & 28.85 & 47.65 & 23.50 \\
\hline $11 \mathrm{H}-5,50-52$ & 99. & 22. & & \\
\hline $11 \mathrm{H}-5,70-72$ & 99.41 & 20.27 & & \\
\hline $11 \mathrm{H}-5,80-82$ & 99.51 & 22.92 & & \\
\hline $11 \mathrm{H}-5,89-93$ & 99.59 & 40.34 & 35.10 & 24.55 \\
\hline $11 \mathrm{H}-5,105-106$ & 99.75 & 42.04 & 38.81 & 19.14 \\
\hline $11 \mathrm{H}-5,110-112$ & 99.81 & 32.33 & & \\
\hline $11 \mathrm{H}-5,136-137$ & 100.06 & 54.95 & 29.73 & 15.31 \\
\hline $11 \mathrm{H}-5,140-142$ & 100.11 & 52.62 & & \\
\hline $11 \mathrm{H}-6,15-16$ & 100.35 & 39.61 & 40.21 & 20.17 \\
\hline $11 \mathrm{H}-6,30-32$ & 100.51 & 36.86 & & \\
\hline $11 \mathrm{H}-6,45-46$ & 100.65 & 36.05 & 45.76 & 18.19 \\
\hline $11 \mathrm{H}-6,50-52$ & 100.71 & 42.83 & & \\
\hline $11 \mathrm{H}-6,70-74$ & 100.92 & 49.60 & & \\
\hline $11 \mathrm{H}-6,75-76$ & 100.95 & 48.27 & 40.59 & 11.14 \\
\hline $11 \mathrm{H}-6,80-82$ & 101.01 & 45.83 & & \\
\hline $11 \mathrm{H}-6,89-93$ & 101.09 & 53.84 & 31.26 & 14.89 \\
\hline $11 \mathrm{H}-6,110-112$ & 101.31 & 49.25 & & \\
\hline $11 \mathrm{H}-6,120-122$ & 101.41 & 37.83 & & \\
\hline $11 \mathrm{H}-6,136-137$ & 101.56 & 52.87 & 32.00 & 15.12 \\
\hline $11 \mathrm{H}-6,140-142$ & 101.61 & 53.83 & & \\
\hline $11 \mathrm{H}-7,10-14$ & 101.82 & 83.90 & & \\
\hline $11 \mathrm{H}-7,15-16$ & 101.85 & 88.14 & 2.42 & 9.43 \\
\hline $11 \mathrm{H}-7,20-22$ & 101.91 & 84.32 & & \\
\hline $11 \mathrm{H}-7,24-26$ & 101.95 & 81.25 & & \\
\hline $11 \mathrm{H}-7,45-46$ & 102.15 & 88.62 & 4.13 & 7.24 \\
\hline $12 \mathrm{H}-1,16-17$ & 102.36 & 68.85 & 13.31 & 17.83 \\
\hline $12 \mathrm{H}-1,20-22$ & 102.41 & 62.17 & & \\
\hline $12 \mathrm{H}-1,50-52$ & 102.71 & 67.25 & & \\
\hline $12 \mathrm{H}-1,53-57$ & 102.73 & 70.82 & 17.04 & 12.13 \\
\hline $12 \mathrm{H}-1,58-60$ & 102.79 & 63.22 & & \\
\hline $12 \mathrm{H}-1,70-74$ & 102.92 & 72.90 & & \\
\hline $12 \mathrm{H}-1,77-78$ & 102.97 & 69.92 & 15.10 & 14.97 \\
\hline $12 \mathrm{H}-1,80-82$ & 103.01 & 73.42 & & \\
\hline $12 \mathrm{H}-1,105-106$ & 103.25 & 48.51 & 31.83 & 19.65 \\
\hline $12 \mathrm{H}-1,110-112$ & 103.31 & 68.50 & & \\
\hline $12 \mathrm{H}-1,135-136$ & 103.55 & 61.07 & 26.91 & 12.01 \\
\hline $12 \mathrm{H}-1,140-142$ & 103.61 & 75.25 & & \\
\hline $12 \mathrm{H}-2,10-14$ & 103.82 & 79.30 & & \\
\hline $12 \mathrm{H}-2,16-17$ & 103.86 & 78.28 & 12.10 & 9.61 \\
\hline $12 \mathrm{H}-2,20-22$ & 103.91 & 74.83 & & \\
\hline $12 \mathrm{H}-2,50-52$ & 104.21 & 33.0 & & \\
\hline $12 \mathrm{H}-2,53-57$ & 104.23 & 33.05 & 44.33 & 22.61 \\
\hline $12 \mathrm{H}-2,58-60$ & 104.29 & 33.86 & & \\
\hline $12 \mathrm{H}-2,76-77$ & 104.46 & 42.72 & 37.04 & 20.23 \\
\hline $12 \mathrm{H}-2,80-82$ & 104.51 & 44.92 & & \\
\hline $12 \mathrm{H}-2,105-106$ & 104.75 & 73.88 & 15.64 & 10.47 \\
\hline $12 \mathrm{H}-2,110-112$ & 104.81 & 75.25 & & \\
\hline $12 \mathrm{H}-2,135-136$ & 105.05 & 69.51 & 16.94 & 13.54 \\
\hline $12 \mathrm{H}-2,140-142$ & 105.11 & 68.63 & & \\
\hline $12 \mathrm{H}-3,10-14$ & 105.32 & 65.90 & & \\
\hline $12 \mathrm{H}-3,16-17$ & 105.36 & 61.35 & 26.70 & 11.94 \\
\hline $12 \mathrm{H}-3,20-22$ & 105.41 & 62.25 & & \\
\hline $12 \mathrm{H}-3,50-52$ & 105.71 & 66.46 & & \\
\hline
\end{tabular}

APPENDIX (continued).

\begin{tabular}{|c|c|c|c|c|}
\hline $\begin{array}{l}\text { Core, section, } \\
\text { interval }(\mathrm{cm})\end{array}$ & $\begin{array}{l}\text { Depth } \\
\text { (mbsf) }\end{array}$ & $\begin{array}{c}\mathrm{CaCO}_{3} \\
(\%)\end{array}$ & $\underset{(\%)}{\text { Opal }}$ & $\begin{array}{l}\text { Other } \\
(\%)\end{array}$ \\
\hline $12 \mathrm{H}-3,53-57$ & 105.73 & 68.94 & 13.07 & 17.98 \\
\hline $12 \mathrm{H}-3,58-60$ & 105.79 & 59.80 & & \\
\hline $12 \mathrm{H}-3,75-76$ & 105.95 & 81.74 & 6.71 & 11.54 \\
\hline $12 \mathrm{H}-3,80-82$ & 106.01 & 75.33 & & \\
\hline $12 \mathrm{H}-3,105-106$ & 106.25 & 83.37 & 5.78 & 10.84 \\
\hline $12 \mathrm{H}-3,110-112$ & 106.31 & 77.08 & & \\
\hline $12 \mathrm{H}-3,135-136$ & 106.55 & 72.00 & 13.55 & 14.44 \\
\hline $12 \mathrm{H}-3,140-142$ & 106.61 & 75.31 & & \\
\hline $12 \mathrm{H}-4,16-17$ & 106.86 & 59.82 & 14.05 & 26.12 \\
\hline $12 \mathrm{H}-4,20-22$ & 106.91 & 63.00 & & \\
\hline $12 \mathrm{H}-4,50-52$ & 107.21 & 81.00 & & \\
\hline $12 \mathrm{H}-4,53-57$ & 107.23 & 86.71 & 6.19 & 7.09 \\
\hline $12 \mathrm{H}-4,70-74$ & 107.42 & 70.40 & & \\
\hline $12 \mathrm{H}-4,76-77$ & 107.46 & 72.93 & 13.64 & 13.42 \\
\hline $12 \mathrm{H}-4,80-82$ & 107.51 & 67.00 & & \\
\hline $12 \mathrm{H}-4,105-106$ & 107.75 & 78.26 & 10.54 & 11.19 \\
\hline $12 \mathrm{H}-4,110-112$ & 107.81 & 70.58 & & \\
\hline $12 \mathrm{H}-4,135-136$ & 108. & 82. & 8.53 & 8.83 \\
\hline $12 \mathrm{H}-4,140-142$ & 108. & 77. & & \\
\hline $12 \mathrm{H}-5,15-16$ & 108.35 & 82.58 & 8.62 & 8.79 \\
\hline $12 \mathrm{H}-5,20-22$ & 108.41 & 81.00 & & \\
\hline $12 \mathrm{H}-5,50-52$ & 108.71 & 67.58 & & \\
\hline $12 \mathrm{H}-5,53-57$ & 108.73 & 71.49 & 15.08 & 13.42 \\
\hline $12 \mathrm{H}-5,58-60$ & 108.79 & 76.48 & & \\
\hline $12 \mathrm{H}-5,70-74$ & 108.92 & 71.60 & & \\
\hline $12 \mathrm{H}-5,76-77$ & 108.96 & 74.8 & 13.64 & 11.54 \\
\hline $12 \mathrm{H}-5,80-82$ & 109. & 69. & & \\
\hline $12 \mathrm{H}-5,105-106$ & 109.2 & 76. & 12.00 & 11.32 \\
\hline $12 \mathrm{H}-5,110-112$ & 109 & 76 & & \\
\hline $12 \mathrm{H}-5,145-150$ & 109.66 & 80.11 & 7.47 & 12.41 \\
\hline $12 \mathrm{H}-6,0-5$ & 109.70 & 81.73 & 8.20 & 10.06 \\
\hline $12 \mathrm{H}-6,10-14$ & 109.82 & 75.80 & & \\
\hline $12 \mathrm{H}-6,20-22$ & 109.91 & 70.17 & & \\
\hline $12 \mathrm{H}-6,50-52$ & 110.21 & 78.58 & & \\
\hline $12 \mathrm{H}-6,53-57$ & 110.23 & 81.37 & 9.90 & 8.72 \\
\hline $12 \mathrm{H}-6,58-60$ & 110.29 & 73.89 & & \\
\hline $12 \mathrm{H}-6,75-76$ & 110.4 & 82.61 & 9.26 & 8.12 \\
\hline $12 \mathrm{H}-6,105-106$ & 110. & 82. & 9.43 & 8.53 \\
\hline $12 \mathrm{H}-6,110-112$ & 110.81 & 74 & & \\
\hline $12 \mathrm{H}-6,135-136$ & 111.05 & 80.31 & 10.19 & 9.49 \\
\hline $12 \mathrm{H}-6,140-142$ & 111.11 & 77.00 & & \\
\hline $13 \mathrm{H}-1,15-16$ & 111.85 & 61.74 & 20.69 & 17.56 \\
\hline $13 \mathrm{H}-1,20-22$ & 111.91 & 54.00 & & \\
\hline $13 \mathrm{H}-1,45-46$ & 112.15 & 58.84 & 22.24 & 18.91 \\
\hline $13 \mathrm{H}-1,50-52$ & 112.21 & 51.92 & & \\
\hline $13 \mathrm{H}-1,70-74$ & 112.42 & 17.20 & & \\
\hline $13 \mathrm{H}-1,76-77$ & 112.46 & 21.59 & 49.16 & 29.25 \\
\hline $13 \mathrm{H}-1,80-82$ & 112.51 & 14.25 & & \\
\hline $13 \mathrm{H}-1,100-102$ & 112.7 & 21. & & \\
\hline $13 \mathrm{H}-1,103-104$ & 112.73 & 21.23 & 50.69 & 28.07 \\
\hline $13 \mathrm{H}-1,110-112$ & 112.81 & 20.00 & & \\
\hline $13 \mathrm{H}-1,123-127$ & 112.93 & 18.47 & 52.39 & 29.13 \\
\hline $13 \mathrm{H}-\mathrm{I}, 140-142$ & 113.11 & 20.10 & & \\
\hline $13 \mathrm{H}-2,10-14$ & 113.32 & 49.40 & & \\
\hline $13 \mathrm{H}-2,16-17$ & 113.36 & 54.63 & 23.80 & 21.56 \\
\hline $13 \mathrm{H}-2,20-22$ & 113.41 & 55.25 . & & \\
\hline $13 \mathrm{H}-2,30-32$ & 113.51 & 58.96 & & \\
\hline $13 \mathrm{H}-2,45-46$ & 113.65 & 61.34 & 17.15 & 21.50 \\
\hline $13 \mathrm{H}-2,50-52$ & 113.71 & 72.08 & & \\
\hline $13 \mathrm{H}-2,76-77$ & 113.96 & 27.22 & 46.10 & 26.68 \\
\hline $13 \mathrm{H}-2,80-82$ & 114.01 & 16.42 & & \\
\hline $13 \mathrm{H}-2,100-102$ & 114.21 & 23.10 & & \\
\hline $13 \mathrm{H}-2,103-104$ & 114.23 & 22.14 & 50.58 & 27.28 \\
\hline $13 \mathrm{H}-2,110-112$ & 114.31 & 13.50 & & \\
\hline $13 \mathrm{H}-2,123-127$ & 114.43 & 28.82 & 40.65 & 30.52 \\
\hline $13 \mathrm{H}-2,140-142$ & 114.61 & 34.50 & & \\
\hline $13 \mathrm{H}-3,10-14$ & 114.82 & 57. & & \\
\hline $13 \mathrm{H}-3,15-16$ & 114.85 & 60.88 & 20.20 & 18.92 \\
\hline $13 \mathrm{H}-3,20-22$ & 114.91 & 66.2 & & \\
\hline $13 \mathrm{H}-3,45-46$ & 115.15 & 68.96 & 12.87 & 18.16 \\
\hline $13 \mathrm{H}-3,50-52$ & 115.21 & 69.25 & & \\
\hline $13 \mathrm{H}-3,77-78$ & 115.47 & 70.84 & 12.50 & 16.65 \\
\hline $13 \mathrm{H}-3,80-82$ & 115.51 & 71.00 & & \\
\hline $13 \mathrm{H}-3,100-102$ & 115.71 & 75.64 & & \\
\hline $13 \mathrm{H}-3,105-106$ & 115.75 & 74.39 & 9.84 & 15.76 \\
\hline $13 \mathrm{H}-3,110-112$ & 115.81 & 69.91 & & \\
\hline $13 \mathrm{H}-3,123-127$ & 115.93 & 57.78 & 21.05 & 21.16 \\
\hline
\end{tabular}


APPENDIX (continued).

\begin{tabular}{|c|c|c|c|c|}
\hline $\begin{array}{l}\text { Core, section, } \\
\text { interval }(\mathrm{cm})\end{array}$ & $\begin{array}{l}\text { Depth } \\
\text { (mbsf) }\end{array}$ & $\begin{array}{c}\mathrm{CaCO}_{3} \\
(\%)\end{array}$ & $\begin{array}{c}\text { Opal } \\
(\%)\end{array}$ & $\begin{array}{l}\text { Other } \\
(\%)\end{array}$ \\
\hline $13 \mathrm{H}-3,140-142$ & 116.11 & 65.00 & & \\
\hline $13 \mathrm{H}-4,10-14$ & 116.32 & 64.50 & & \\
\hline $13 \mathrm{H}-4,16-17$ & 116.36 & 65.83 & 14.63 & 19.53 \\
\hline $13 \mathrm{H}-4,20-22$ & 116.41 & 63.17 & & \\
\hline $13 \mathrm{H}-4,45-46$ & 116.65 & 66.00 & 12.94 & 21.06 \\
\hline $13 \mathrm{H}-4,50-52$ & 116.71 & 46.86 & & \\
\hline $13 \mathrm{H}-4,76-77$ & 116.96 & 70.81 & 10.33 & 18.85 \\
\hline $13 \mathrm{H}-4,80-82$ & 117.01 & 79.83 & & \\
\hline $13 \mathrm{H}-4,103-104$ & 117.23 & 81.97 & 7.88 & 10.14 \\
\hline $13 \mathrm{H}-4,110-112$ & 117.31 & 72.83 & & \\
\hline $13 \mathrm{H}-4,123-127$ & 117.43 & 68.81 & 14.27 & 16.91 \\
\hline $13 \mathrm{H}-4,140-142$ & 117.61 & 69.95 & & \\
\hline $13 \mathrm{H}-5,10-14$ & 117.82 & 70.30 & & \\
\hline $13 \mathrm{H}-5,16-17$ & 117.86 & 68.30 & 14.52 & 17.17 \\
\hline $13 \mathrm{H}-5,20-22$ & 117.91 & 66.17 & & \\
\hline $13 \mathrm{H}-5,45-46$ & 118.15 & 56.07 & 20.62 & 23.30 \\
\hline $13 \mathrm{H}-5,50-52$ & 118.21 & 50.33 & & \\
\hline $13 \mathrm{H}-5,76-77$ & 118.46 & 66.63 & 15.55 & 17.81 \\
\hline $13 \mathrm{H}-5,105-106$ & 118.75 & 52.43 & 23.91 & 23.65 \\
\hline $13 \mathrm{H}-5,110-112$ & 118.81 & 59.42 & & \\
\hline $13 \mathrm{H}-5,123-127$ & 118.93 & 77.00 & 8.71 & 14.28 \\
\hline $13 \mathrm{H}-5,140-142$ & 119.11 & 83.33 & & \\
\hline $13 \mathrm{H}-6,0-5$ & 119.20 & 71.03 & 13.33 & 15.63 \\
\hline $13 \mathrm{H}-6,20-22$ & 119.41 & 75.75 & & \\
\hline $13 \mathrm{H}-6,46-47$ & 119.65 & 80.51 & 7.54 & 11.94 \\
\hline $13 \mathrm{H}-6,50-52$ & 119.71 & 73.38 & & \\
\hline $13 \mathrm{H}-6,76-77$ & 119.96 & 79.7 & 7.27 & 12.99 \\
\hline $13 \mathrm{H}-6,80-82$ & 120.01 & 78.3 & & \\
\hline $13 \mathrm{H}-6,105-106$ & 120.25 & 79.5 & 9.52 & 10.54 \\
\hline $13 \mathrm{H}-6,110-112$ & 120.31 & 78.75 & & \\
\hline $13 \mathrm{H}-6,117-121$ & 120.39 & 77.20 & & \\
\hline $13 \mathrm{H}-6,123-127$ & 120.43 & 81.85 & 8.69 & 9.45 \\
\hline $13 \mathrm{H}-6,140-142$ & 120.61 & 79.00 & & \\
\hline $13 \mathrm{H}-7,10-14$ & 120.82 & 72.08 & & \\
\hline $13 \mathrm{H}-7,15-16$ & 120.85 & 70.23 & 13.32 & 16.44 \\
\hline $13 \mathrm{H}-7,20-22$ & 120.91 & 69.08 & & \\
\hline $13 \mathrm{H}-7,45-46$ & 121.15 & 72.01 & 13.90 & 14.08 \\
\hline $13 \mathrm{H}-7,50-52$ & 121.21 & 70.58 & & \\
\hline $14 \mathrm{H}-1,16-17$ & 121.36 & 66.01 & 16.29 & 17.69 \\
\hline $14 \mathrm{H}-1,20-22$ & 121.41 & 58.41 & & \\
\hline $14 \mathrm{H}-1,45-46$ & 121.65 & 69.61 & 13.93 & 16.45 \\
\hline $14 \mathrm{H}-1,50-52$ & 121.71 & 70.67 & & \\
\hline $14 \mathrm{H}-1,70-74$ & 121.92 & 69.90 & & \\
\hline $14 \mathrm{H}-1,75-76$ & 121.95 & 61.06 & 18.39 & 20.54 \\
\hline $14 \mathrm{H}-1,80-82$ & 122.01 & 62.58 & & \\
\hline $14 \mathrm{H}-1,100-102$ & 122.21 & 77.40 & & \\
\hline $14 \mathrm{H}-1,105-106$ & 122.25 & 77.85 & 9.52 & 12.62 \\
\hline $14 \mathrm{H}-1,109-111$ & 122.30 & 77.25 & & \\
\hline $14 \mathrm{H}-1,139-141$ & 122.60 & 69.00 & & \\
\hline $14 \mathrm{H}-1,145-149$ & 122.65 & 74.07 & 13.32 & 12.61 \\
\hline $14 \mathrm{H}-2,16-17$ & 122.86 & 59.94 & 18.29 & 21.76 \\
\hline $14 \mathrm{H}-2,20-22$ & 122.91 & 49.83 & & \\
\hline $14 \mathrm{H}-2,46-47$ & 123.16 & 74.67 & 12.10 & 13.22 \\
\hline $14 \mathrm{H}-2,50-52$ & 123.21 & 72.08 & & \\
\hline $14 \mathrm{H}-2,70-74$ & 123.42 & 63.50 & & \\
\hline $14 \mathrm{H}-2,75-76$ & 123.45 & 65.57 & 14.36 & 20.06 \\
\hline $14 \mathrm{H}-2,80-82$ & 123.51 & 64.58 & & \\
\hline $14 \mathrm{H}-2,100-102$ & 123.71 & 61.47 & & \\
\hline $14 \mathrm{H}-2,105-106$ & 123.75 & 62.88 & 19.35 & 17.76 \\
\hline $14 \mathrm{H}-2,109-111$ & 123.80 & 61.83 & & \\
\hline $14 \mathrm{H}-2,139-141$ & 124.10 & 76.17 & & \\
\hline $14 \mathrm{H}-2,145-149$ & 124.15 & 75.27 & 13.35 & 11.37 \\
\hline $14 \mathrm{H}-3,10-14$ & 124.32 & 78.90 & & \\
\hline $14 \mathrm{H}-3,16-17$ & 124.36 & 72.39 & 12.56 & 15.04 \\
\hline $14 \mathrm{H}-3,20-22$ & 124.41 & 63.08 & & \\
\hline $14 \mathrm{H}-3,46-47$ & 124.66 & 60.47 & 20.49 & 19.04 \\
\hline $14 \mathrm{H}-3,50-52$ & 124.71 & 61.25 & & \\
\hline $14 \mathrm{H}-3,77-78$ & 124.97 & 80.25 & 8.53 & 11.21 \\
\hline $14 \mathrm{H}-3,80-82$ & 125.01 & 75.83 & & \\
\hline $14 \mathrm{H}-3,105-106$ & 125.25 & 75.42 & 13.90 & 10.67 \\
\hline $14 \mathrm{H}-3,109-111$ & 125.30 & 67.00 & & \\
\hline $14 \mathrm{H}-3,139-141$ & 125.60 & 63.17 & & \\
\hline $14 \mathrm{H}-3,145-149$ & 125.65 & 66.77 & 14.24 & 18.98 \\
\hline $14 \mathrm{H}-4,16-17$ & 125.86 & 75.43 & 10.40 & 14.16 \\
\hline $14 \mathrm{H}-4,20-22$ & 125.91 & 63.58 & & \\
\hline $14 \mathrm{H}-4,46-47$ & 126.16 & 69.81 & 10.76 & 19.42 \\
\hline $14 \mathrm{H}-4,50-52$ & 126.21 & 76.53 & & \\
\hline
\end{tabular}

APPENDIX (continued).

\begin{tabular}{|c|c|c|c|c|}
\hline $\begin{array}{l}\text { Core, section, } \\
\text { interval }(\mathrm{cm})\end{array}$ & $\begin{array}{l}\text { Depth } \\
\text { (mbsf) }\end{array}$ & $\begin{array}{c}\mathrm{CaCO}_{3} \\
(\%)\end{array}$ & $\begin{array}{l}\text { Opal } \\
(\%)\end{array}$ & $\begin{array}{l}\text { Other } \\
(\%)\end{array}$ \\
\hline $14 \mathrm{H}-4,70-74$ & 126.42 & 69.30 & & \\
\hline $14 \mathrm{H}-4,76-77$ & 126.46 & 53.19 & 26.55 & 20.25 \\
\hline $14 \mathrm{H}-4,80-82$ & 126.51 & 46.42 & & \\
\hline $14 \mathrm{H}-4,100-102$ & 126.71 & 44.45 & & \\
\hline $14 \mathrm{H}-4,105-106$ & 126.75 & 43.69 & 30.96 & 25.34 \\
\hline $14 \mathrm{H}-4,109-111$ & 126.80 & 46.17 & & \\
\hline $14 \mathrm{H}-4,139-141$ & 127.10 & 57.67 & & \\
\hline $14 \mathrm{H}-4,145-146$ & 127.15 & 54.25 & 28.80 & 16.94 \\
\hline $14 \mathrm{H}-4,145-150$ & 127.16 & 53.47 & 28.76 & 17.76 \\
\hline $14 \mathrm{H}-5,10-14$ & 127.32 & 69.90 & & \\
\hline $14 \mathrm{H}-5,16-17$ & 127.36 & 47.88 & 34.49 & 17.63 \\
\hline $14 \mathrm{H}-5,20-22$ & 127.41 & 26.92 & & \\
\hline $14 \mathrm{H}-5,46-47$ & 127.66 & 44.12 & 28.87 & 27.00 \\
\hline $14 \mathrm{H}-5,50-52$ & 127.71 & 44.70 & & \\
\hline $14 \mathrm{H}-5,76-77$ & 127.96 & 87.85 & 3.73 & 8.41 \\
\hline $14 \mathrm{H}-5,80-82$ & 128.01 & 86.58 & & \\
\hline $14 \mathrm{H}-5,105-106$ & 128.25 & 88.70 & 2.25 & 9.04 \\
\hline $14 \mathrm{H}-5,130-132$ & 128.51 & 89.24 & & \\
\hline $14 \mathrm{H}-5,139-141$ & 128.60 & 63.10 & & \\
\hline $14 \mathrm{H}-5,145-149$ & 128.65 & 35.03 & 33.19 & 31.77 \\
\hline $14 \mathrm{H}-6,16-17$ & 128.86 & 24.06 & 46.56 & 29.37 \\
\hline $14 \mathrm{H}-6,20-22$ & 128.91 & 60.50 & & \\
\hline $14 \mathrm{H}-6,46-47$ & 129.16 & 51.40 & 19.90 & 28.69 \\
\hline $14 \mathrm{H}-6,50-52$ & 129.21 & 51.90 & & \\
\hline $14 \mathrm{H}-6,70-74$ & 129.42 & 25.10 & & \\
\hline $14 \mathrm{H}-6,80-82$ & 129.51 & 48.17 & & \\
\hline $15 \mathrm{H}-1,10-14$ & 130.82 & 32.10 & & \\
\hline $15 \mathrm{H}-1,16-17$ & 130.86 & 34.74 & 41.38 & 23.87 \\
\hline $15 \mathrm{H}-1,20-22$ & 130.91 & 36.25 & & \\
\hline $15 \mathrm{H}-1,30-34$ & 131.00 & 33.15 & 44.19 & 22.65 \\
\hline $15 \mathrm{H}-1,50-52$ & 131.21 & 46.00 & & \\
\hline $15 \mathrm{H}-1,76-77$ & 131.46 & 77.86 & 8.42 & 13.71 \\
\hline $15 \mathrm{H}-1,80-82$ & 131.51 & 66.83 & & \\
\hline $15 \mathrm{H}-1,100-102$ & 131.71 & 74.56 & & \\
\hline $15 \mathrm{H}-1,109-110$ & 131.79 & 78.43 & 8.99 & 12.57 \\
\hline $15 \mathrm{H}-1,110-112$ & 131.81 & 77.75 & & \\
\hline $15 \mathrm{H}-1,135-136$ & 132.05 & 66.65 & 14.23 & 19.11 \\
\hline $15 \mathrm{H}-2,10-14$ & 132.32 & 56.90 & & \\
\hline $15 \mathrm{H}-2,16-17$ & 132.36 & 63.58 & 18.90 & 17.51 \\
\hline $15 \mathrm{H}-2,20-22$ & 132.41 & 55.08 & & \\
\hline $15 \mathrm{H}-2,30-34$ & 132.50 & 59.54 & 20.31 & 20.14 \\
\hline $15 \mathrm{H}-2,50-52$ & 132.71 & 60.50 & & \\
\hline $15 \mathrm{H}-2,76-77$ & 132.96 & 70.28 & 13.98 & 15.65 \\
\hline $15 \mathrm{H}-2,80-82$ & 133.01 & 54.25 & & \\
\hline $15 \mathrm{H}-2,100-102$ & 133.21 & 50.96 & & \\
\hline $15 \mathrm{H}-2,103-104$ & 133.23 & 50.97 & 27.04 & 21.98 \\
\hline $15 \mathrm{H}-2,110-112$ & 133.31 & 57.08 & & \\
\hline $15 \mathrm{H}-2,135-135$ & 133.55 & 51.50 & 28.75 & 19.74 \\
\hline $15 \mathrm{H}-2,140-142$ & 133.61 & 46.92 & & \\
\hline $15 \mathrm{H}-3,16-17$ & 133.86 & 52.98 & 30.12 & 16.89 \\
\hline $15 \mathrm{H}-3,20-22$ & 133.91 & 57.58 & & \\
\hline $15 \mathrm{H}-3,30-34$ & 134.00 & 53.89 & 23.67 & 22.43 \\
\hline $15 \mathrm{H}-3,50-52$ & 134.21 & 51.42 & & \\
\hline $15 \mathrm{H}-3,70-74$ & 134.42 & 50.30 & & \\
\hline $15 \mathrm{H}-3,77-78$ & 134.47 & 49.98 & 27.70 & 22.31 \\
\hline $15 \mathrm{H}-3,80-82$ & 134.51 & 50.25 & & \\
\hline $15 \mathrm{H}-3,99-100$ & 134.69 & 48.56 & 25.91 & 25.52 \\
\hline $15 \mathrm{H}-3,100-102$ & 134.71 & 49.87 & & \\
\hline $15 \mathrm{H}-3,110-112$ & 134.81 & 45.92 & & \\
\hline $15 \mathrm{H}-3,135-136$ & 135.05 & 36.96 & 38.06 & 24.97 \\
\hline $15 \mathrm{H}-3,140-142$ & 135.11 & 32.83 & & \\
\hline $15 \mathrm{H}-4,10-14$ & 135.32 & 57.25 & & \\
\hline $15 \mathrm{H}-4,16-17$ & 135.36 & 54.39 & 22.64 & 22.96 \\
\hline $15 \mathrm{H}-4,20-22$ & 135.41 & 50.33 & & \\
\hline $15 \mathrm{H}-4,30-34$ & 135.50 & 53.39 & 23.69 & 22.91 \\
\hline $15 \mathrm{H}-4,50-52$ & 135.71 & 52.25 & & \\
\hline $15 \mathrm{H}-4,76-77$ & 135.96 & 39.93 & 32.17 & 27.90 \\
\hline $15 \mathrm{H}-4,80-82$ & 136.01 & 42.50 & & \\
\hline $15 \mathrm{H}-4,101-102$ & 136.21 & 58.32 & 19.88 & 21.79 \\
\hline $15 \mathrm{H}-4,110-112$ & 136.31 & 60.42 & & \\
\hline $15 \mathrm{H}-4,135-136$ & 136.55 & 78.44 & 7.45 & 14.10 \\
\hline $15 \mathrm{H}-4,140-142$ & 136.61 & 73.75 & & \\
\hline $15 \mathrm{H}-5,10-14$ & 136.82 & 49.25 & & \\
\hline $15 \mathrm{H}-5,17-18$ & 136.87 & 53.00 & 26.49 & 20.50 \\
\hline $15 \mathrm{H}-5,20-22$ & 136.91 & 41.00 & & \\
\hline $15 \mathrm{H}-5,30-34$ & 137.00 & 57.45 & 16.42 & 26.12 \\
\hline $15 \mathrm{H}-5,50-52$ & 137.21 & 57.56 & & \\
\hline
\end{tabular}


APPENDIX (continued).

\begin{tabular}{|c|c|c|c|c|}
\hline $\begin{array}{l}\text { Core, section, } \\
\text { interval }(\mathrm{cm})\end{array}$ & $\begin{array}{l}\text { Depth } \\
\text { (mbsf) }\end{array}$ & $\begin{array}{c}\mathrm{CaCO}_{3} \\
(\%)\end{array}$ & $\begin{array}{l}\text { Opal } \\
(\%)\end{array}$ & $\begin{array}{l}\text { Other } \\
(\%)\end{array}$ \\
\hline $15 \mathrm{H}-5,75-76$ & 137.45 & 43.07 & 27.84 & 29.08 \\
\hline $15 \mathrm{H}-5,80-82$ & 137.51 & 31.17 & & \\
\hline $15 \mathrm{H}-5,100-102$ & 137.71 & 38.79 & & \\
\hline $15 \mathrm{H}-5,108-109$ & 137.78 & 35.18 & 36.39 & 28.42 \\
\hline $15 \mathrm{H}-5,145-150$ & 138.16 & 42.51 & 35.91 & 21.57 \\
\hline $15 \mathrm{H}-6,0-5$ & 138.20 & 40.63 & 38.07 & 21.29 \\
\hline $15 \mathrm{H}-6,10-14$ & 138.32 & 40.42 & & \\
\hline $15 \mathrm{H}-6,20-22$ & 138.41 & 31.67 & & \\
\hline $15 \mathrm{H}-6,30-34$ & 138.50 & 44.10 & 32.77 & 23.12 \\
\hline $15 \mathrm{H}-6,50-52$ & 138.71 & 42.17 & & \\
\hline $15 \mathrm{H}-6,76-77$ & 138.96 & 49.95 & 35.10 & 14.94 \\
\hline $15 \mathrm{H}-6,80-82$ & 139.01 & 46.08 & & \\
\hline $15 \mathrm{H}-6,101-102$ & 139.21 & 45.49 & 29.95 & 24.55 \\
\hline $15 \mathrm{H}-6,110-112$ & 139.31 & 45.25 & & \\
\hline $15 \mathrm{H}-6,135-136$ & 139.55 & 60.29 & 29.97 & 9.73 \\
\hline $15 \mathrm{H}-6,140-142$ & 139.61 & 38.25 & & \\
\hline $15 \mathrm{H}-7,16-17$ & 139.86 & 34.88 & 36.17 & 28.94 \\
\hline $15 \mathrm{H}-7,20-22$ & 139.91 & 32.08 & & \\
\hline $15 \mathrm{H}-7,30-34$ & 140.00 & 38.58 & 38.79 & 22.62 \\
\hline $15 \mathrm{H}-7,50-52$ & 140.21 & 52.83 & & \\
\hline $15 \mathrm{H}-7,54-55$ & 140.24 & 49.91 & 25.68 & 24.40 \\
\hline $16 \mathrm{H}-1,10-14$ & 140.32 & 19.25 & & \\
\hline $16 \mathrm{H}-1,15-16$ & 140.35 & 26.01 & 47.75 & 26.23 \\
\hline $16 \mathrm{H}-1,20-22$ & 140.41 & 19.58 & & \\
\hline $16 \mathrm{H}-1,45-46$ & 140.65 & 25.95 & 48.02 & 26.02 \\
\hline $16 \mathrm{H}-1,50-52$ & 140.71 & 24.50 & & \\
\hline $16 \mathrm{H}-1,60-64$ & 140.80 & 23.87 & 49.55 & 26.57 \\
\hline $16 \mathrm{H}-1,80-82$ & 141.01 & 25.83 & & \\
\hline $16 \mathrm{H}-1,105-106$ & 141.25 & 19.63 & 55.03 & 25.33 \\
\hline $16 \mathrm{H}-1,110-112$ & 141.31 & 21.25 & & \\
\hline $16 \mathrm{H}-1,136-137$ & 141.56 & 15.92 & 55.57 & 28.50 \\
\hline $16 \mathrm{H}-1,144-146$ & 141.65 & 18.83 & & \\
\hline $16 \mathrm{H}-2,14-15$ & 141.84 & 22.97 & 51.61 & 25.42 \\
\hline $16 \mathrm{H}-2,20-22$ & 141.91 & 26.16 & & \\
\hline $16 \mathrm{H}-2,45-46$ & 142.15 & 31.39 & 44.22 & 24.38 \\
\hline $16 \mathrm{H}-2,50-52$ & 142.21 & 31.75 & & \\
\hline $16 \mathrm{H}-2,60-64$ & 142.30 & 26.03 & 49.04 & 24.92 \\
\hline $16 \mathrm{H}-2,80-82$ & 142.51 & 25.58 & & \\
\hline $16 \mathrm{H}-2,100-102$ & 142.71 & 23.35 & & \\
\hline $16 \mathrm{H}-2,105-106$ & 142.75 & 24.66 & 51.04 & 24.29 \\
\hline $16 \mathrm{H}-2,110-112$ & 142.81 & 23.00 & & \\
\hline $16 \mathrm{H}-2,120-124$ & 142.92 & 27.83 & & \\
\hline $16 \mathrm{H}-2,137-138$ & 143.07 & 25.34 & 52.33 & 22.32 \\
\hline $16 \mathrm{H}-2,144-146$ & 143.15 & 26.92 & & \\
\hline $16 \mathrm{H}-3,14-15$ & 143.34 & 22.66 & 49.55 & 27.78 \\
\hline $16 \mathrm{H}-3,20-22$ & 143.41 & 17.29 & & \\
\hline $16 \mathrm{H}-3,45-46$ & 143.65 & 21.97 & 47.33 & 30.69 \\
\hline $16 \mathrm{H}-3,50-52$ & 143.71 & 28.83 & & \\
\hline $16 \mathrm{H}-3,60-64$ & 143.80 & 47.82 & 25.84 & 26.33 \\
\hline $16 \mathrm{H}-3,70-74$ & 143.92 & 62.83 & & \\
\hline $16 \mathrm{H}-3,80-82$ & 144.01 & 52.08 & & \\
\hline $16 \mathrm{H}-3,100-102$ & 144.21 & 77.22 & & \\
\hline $16 \mathrm{H}-3,105-106$ & 144.25 & 74.92 & 11.22 & 13.85 \\
\hline $16 \mathrm{H}-3,110-112$ & 144.31 & 73.92 & & \\
\hline $16 \mathrm{H}-3,133-134$ & 144.53 & 83.47 & 5.79 & 10.74 \\
\hline $16 \mathrm{H}-3,144-146$ & 144.65 & 77.70 & & \\
\hline $16 \mathrm{H}-4,0-5$ & 144.71 & 81.05 & 4.60 & 14.34 \\
\hline $16 \mathrm{H}-4,20-22$ & 144.91 & 76.75 & & \\
\hline $16 \mathrm{H}-4,45-46$ & 145.15 & 79.65 & 5.58 & 14.77 \\
\hline $16 \mathrm{H}-4,50-52$ & 145.21 & 78.33 & & \\
\hline $16 \mathrm{H}-4,60-64$ & 145.30 & 78.86 & 5.30 & 15.83 \\
\hline $16 \mathrm{H}-4,80-82$ & 145.51 & 74.08 & & \\
\hline $16 \mathrm{H}-4,100-102$ & 145.71 & 79.81 & & \\
\hline $16 \mathrm{H}-4,105-106$ & 145.75 & 77.88 & 8.24 & 13.87 \\
\hline $16 \mathrm{H}-4,110-112$ & 145.81 & 70.0 & & \\
\hline $16 \mathrm{H}-4,120-124$ & 145.92 & 67.83 & & \\
\hline $16 \mathrm{H}-4,137-138$ & 146.07 & 47.48 & 22.07 & 30.44 \\
\hline $16 \mathrm{H}-4,144-146$ & 146.15 & 64.75 & & \\
\hline $16 \mathrm{H}-5,15-16$ & 146.35 & 48.06 & 26.81 & 25.12 \\
\hline $16 \mathrm{H}-5,20-22$ & 146.41 & 43.58 & & \\
\hline $16 \mathrm{H}-5,45-46$ & 146.65 & 58.86 & 20.11 & 21.03 \\
\hline $16 \mathrm{H}-5,50-52$ & 146.71 & 52.10 & & \\
\hline $16 \mathrm{H}-5,60-64$ & 146.80 & 49.36 & 26.08 & 24.55 \\
\hline $16 \mathrm{H}-5,70-74$ & 146.92 & 52.63 & & \\
\hline $16 \mathrm{H}-5,80-82$ & 147.01 & 41.17 & & \\
\hline $16 \mathrm{H}-5,100-102$ & 147.21 & 41.28 & & \\
\hline $16 \mathrm{H}-5,105-106$ & 147.25 & 42.91 & 31.04 & 26.04 \\
\hline
\end{tabular}

APPENDIX (continued).

\begin{tabular}{|c|c|c|c|c|}
\hline $\begin{array}{l}\text { Core, section, } \\
\text { interval }(\mathrm{cm})\end{array}$ & $\begin{array}{l}\text { Depth } \\
\text { (mbsf) }\end{array}$ & $\begin{array}{c}\mathrm{CaCO}_{3} \\
(\%)\end{array}$ & $\begin{array}{c}\text { Opal } \\
(\%)\end{array}$ & $\begin{array}{l}\text { Other } \\
(\%)\end{array}$ \\
\hline $16 \mathrm{H}-5,110-112$ & 147.31 & 38.58 & & \\
\hline $16 \mathrm{H}-5,132-133$ & 147.52 & 69.10 & 13.61 & 17.10 \\
\hline $16 \mathrm{H}-5,144-146$ & 147.65 & 49.60 & & \\
\hline $16 \mathrm{H}-6,15-16$ & 147.85 & 44.99 & 33.40 & 21.60 \\
\hline $16 \mathrm{H}-6,20-22$ & 147.91 & 41.25 & & \\
\hline $16 \mathrm{H}-6,45-46$ & 148.15 & 68.39 & 9.97 & 21.63 \\
\hline $16 \mathrm{H}-6,50-52$ & 148.21 & 70.00 & & \\
\hline $16 \mathrm{H}-6,60-64$ & 148.30 & 33.08 & 42.34 & 24.57 \\
\hline $16 \mathrm{H}-6,70-74$ & 148.42 & 29.42 & & \\
\hline $16 \mathrm{H}-6,80-82$ & 148.51 & 24.41 & & \\
\hline $16 \mathrm{H}-6,97-98$ & 148.67 & 24.72 & 54.09 & 21.18 \\
\hline $17 X-1,16-17$ & 149.86 & 30.34 & 52.97 & 16.68 \\
\hline $17 X-1,20-22$ & 149.91 & 44.58 & & \\
\hline $17 X-1,40-44$ & 150.10 & 40.72 & 46.44 & 12.83 \\
\hline $17 X-1,76-77$ & 150.46 & 51.75 & 15.98 & 32.28 \\
\hline $17 \mathrm{X}-1,80-82$ & 150.51 & 62.25 & & \\
\hline $17 X-1,106-107$ & 150.76 & 78.15 & 9.82 & 12.02 \\
\hline $17 X-1,110-112$ & 150.81 & 73.16 & & \\
\hline $17 X-1,123-127$ & 150.95 & 79.58 & & \\
\hline $17 X-1,128-129$ & 150.98 & 82.08 & 5.34 & 12.57 \\
\hline $17 X-2,15-16$ & 151.35 & 80.23 & 5.00 & 14.76 \\
\hline $17 X-2,20-22$ & 151.41 & 76.67 & & \\
\hline $17 X-2,40-44$ & 151.60 & 83.61 & 5.09 & 11.29 \\
\hline $17 X-2,50-52$ & 151.71 & 80.42 & & \\
\hline $17 X-2,77-78$ & 151.97 & 75.70 & 9.46 & 14.83 \\
\hline $17 X-2,100-102$ & 152.21 & 82.90 & & \\
\hline $17 X-2,107-108$ & 152.27 & 80.61 & 5.95 & 13.43 \\
\hline $17 X-2,110-112$ & 152.31 & 76.08 & & \\
\hline $17 X-2,135-136$ & 152.55 & 69.60 & 13.43 & 16.96 \\
\hline $17 X-2,136-138$ & 152.57 & 81.75 & & \\
\hline $17 X-2,140-142$ & 152.61 & 55.25 & & \\
\hline $17 X-3,10-14$ & 152.82 & 59.92 & & \\
\hline $17 X-3,17-18$ & 152.87 & 51.59 & 27.15 & 21.25 \\
\hline $17 X-3,20-22$ & 152.91 & 61.08 & & \\
\hline $17 X-3,40-44$ & 153.10 & 68.06 & 17.55 & 14.38 \\
\hline $17 X-3,50-52$ & 153.21 & 65.00 & & \\
\hline $17 X-3,78-79$ & 153.48 & 55.84 & 22.76 & 21.39 \\
\hline $17 X-3,80-82$ & 153.51 & 46.25 & & \\
\hline $17 \mathrm{X}-3,100-102$ & 153.71 & 66.20 & & \\
\hline $17 X-3,105-106$ & 153.75 & 66.62 & 15.92 & 17.45 \\
\hline $17 X-3,110-112$ & 153.81 & 61.83 & & \\
\hline $17 X-3,135-136$ & 154.05 & 51.81 & 28.10 & 20.08 \\
\hline $17 X-3,140-142$ & 154.11 & 54.67 & & \\
\hline $17 X-4,15-16$ & 154.35 & 61.31 & 21.76 & 16.92 \\
\hline $17 X-4,10-14$ & 154.41 & 54.57 & & \\
\hline $17 X-4,40-44$ & 154.60 & 56.85 & 20.74 & 22.40 \\
\hline $17 X-4,50-52$ & 154.71 & 55.67 & & \\
\hline $17 X-4,70-74$ & 154.92 & 63.92 & & \\
\hline $17 X-4,75-76$ & 154.95 & 55.92 & 23.32 & 20.75 \\
\hline $17 X-4,80-82$ & 155.01 & 44.83 & & \\
\hline $17 X-4,100-102$ & 155.21 & 67.39 & & \\
\hline $17 X-4,106-107$ & 155.26 & 70.54 & 17.09 & 12.36 \\
\hline $17 X-4,110-112$ & 155.31 & 73.16 & & \\
\hline $17 X-4,135-136$ & 155.55 & 71.40 & 15.21 & 13.38 \\
\hline $17 X-4,140-142$ & 155.61 & 69.00 & & \\
\hline $17 X-5,0-5$ & 155.72 & 74.84 & 13.75 & 11.40 \\
\hline $17 X-5,20-22$ & 155.91 & 74.50 & & \\
\hline $17 X-5,40-44$ & 156.10 & 43.37 & 28.22 & 28.40 \\
\hline $17 X-5,50-52$ & 156.21 & 64.17 & & \\
\hline $17 X-5,77-78$ & 156.47 & 54.95 & 26.00 & 19.04 \\
\hline $17 X-5,80-82$ & 156.51 & 47.75 & & \\
\hline $17 X-5,100-102$ & 156.71 & 64.89 & & \\
\hline $17 X-5,107-108$ & 156.77 & 56.72 & 24.43 & 18.84 \\
\hline $17 X-5,110-112$ & 156.81 & 55.75 & & \\
\hline $17 X-5,123-127$ & 156.95 & 59.67 & & \\
\hline $17 X-5,135-136$ & 157.05 & 57.57 & 20.69 & 21.73 \\
\hline $17 X-5,140-142$ & 157.11 & 57.42 & & \\
\hline $17 X-6,15-16$ & 157.35 & 78.99 & 10.82 & 10.18 \\
\hline $17 X-6,20-22$ & 157.41 & 71.08 & & \\
\hline $17 X-6,40-44$ & 157.60 & 48.76 & 24.35 & 26.88 \\
\hline $17 X-6,50-52$ & 157.71 & 52.67 & & \\
\hline $17 X-6,75-76$ & 157.95 & 80.98 & 4.87 & 14.14 \\
\hline $17 X-6,80-82$ & 158.01 & 80.92 & & \\
\hline $17 X-6,103-104$ & 158.23 & 84.08 & 4.32 & 11.59 \\
\hline $17 X-6,110-112$ & 158.31 & 82.83 & & \\
\hline $17 X-6,123-127$ & 158.45 & 81.83 & & \\
\hline $17 X-6,135-136$ & 158.55 & 81.04 & 7.07 & 11.89 \\
\hline
\end{tabular}


APPENDIX (continued).

\begin{tabular}{|c|c|c|c|c|}
\hline $\begin{array}{l}\text { Core, section, } \\
\text { interval }(\mathrm{cm})\end{array}$ & $\begin{array}{l}\text { Depth } \\
\text { (mbsf) }\end{array}$ & $\begin{array}{c}\mathrm{CaCO}_{3} \\
(\%)\end{array}$ & $\begin{array}{l}\text { Opal } \\
(\%)\end{array}$ & $\begin{array}{l}\text { Other } \\
(\%)\end{array}$ \\
\hline $17 X-6,140-142$ & 158.61 & 79.08 & & \\
\hline $18 X-1,17-18$ & 159.37 & 69.89 & 10.09 & 20.01 \\
\hline $18 \mathrm{X}-1,20-22$ & 159.41 & 36.25 & & \\
\hline $18 X-1,42-43$ & 159.62 & 50.80 & 19.48 & 29.71 \\
\hline $18 \mathrm{X}-1,50-52$ & 159.71 & 36.90 & & \\
\hline $18 X-1,56-60$ & 159.78 & 66.71 & 8.47 & 24.81 \\
\hline $18 X-1,76-78$ & 159.97 & 70.58 & & \\
\hline $18 X-1,100-102$ & 160.21 & 75.89 & & \\
\hline $18 \mathrm{X}-1,110-112$ & 160.31 & 55.40 & 10.96 & 33.63 \\
\hline $18 \mathrm{X}-1,120-124$ & 160.42 & 45.58 & & \\
\hline $18 X-1,135-136$ & 160.55 & 77.65 & 8.90 & 13.44 \\
\hline $18 \mathrm{X}-1,140-142$ & 160.61 & 70.25 & & \\
\hline $18 X-2,17-18$ & 160.87 & 83.16 & 5.22 & 11.61 \\
\hline $18 X-2,20-22$ & 160.91 & 74.75 & & \\
\hline $18 X-2,50-52$ & 161.21 & 78.58 & & \\
\hline $18 X-2,56-60$ & 161.28 & 82.54 & 3.40 & 14.05 \\
\hline $18 X-2,70-74$ & 161.42 & 73.42 & & \\
\hline $18 X-2,76-77$ & 161.46 & 71.16 & 7.88 & 20.95 \\
\hline $18 X-2,76-78$ & 161.47 & 63.42 & & \\
\hline $18 X-2,100-102$ & 161.71 & 49.62 & & \\
\hline $18 \mathrm{X}-2,104-105$ & 161.74 & 49.71 & 22.80 & 27.48 \\
\hline $18 X-2,110-112$ & 161.82 & 37.58 & & \\
\hline $18 X-2,135-136$ & 162.05 & 69.90 & 8.30 & 21.79 \\
\hline $18 X-2,140-142$ & 162.11 & 68.83 & & \\
\hline $18 X-3,9-10$ & 162.29 & 78.90 & 5.56 & 15.53 \\
\hline $18 X-3,20-22$ & 162.41 & 73.75 & & \\
\hline $18 X-3,50-52$ & 162.71 & 68.25 & & \\
\hline $18 X-3,56-60$ & 162.78 & 74.13 & 7.85 & 18.01 \\
\hline $18 X-3,70-71$ & 162.90 & 75.16 & 8.03 & 16.80 \\
\hline $18 X-3,70-74$ & 162.92 & 73.92 & & \\
\hline $18 X-3,76-78$ & 162.97 & 73.50 & & \\
\hline $18 X-3,107-108$ & 163.27 & 75.06 & 7.75 & 17.18 \\
\hline $18 X-3,110-112$ & 163.31 & 79.83 & & \\
\hline $18 X-3,125-127$ & 163.46 & 54.79 & & \\
\hline $18 X-3,135-136$ & 163.55 & 69.85 & 9.22 & 20.92 \\
\hline $18 X-3,140-142$ & 163.61 & 81.25 & & \\
\hline $18 X-4,10-14$ & 163.82 & 73.75 & & \\
\hline $18 X-4,17-18$ & 163.87 & 72.13 & 9.64 & 18.27 \\
\hline $18 X-4,20-22$ & 163.91 & 81.08 & & \\
\hline $18 X-4,50-52$ & 164.21 & 58.50 & & \\
\hline $18 X-4,56-60$ & 164.28 & 65.52 & 18.64 & 15.83 \\
\hline $18 X-4,76-77$ & 164.46 & 61.77 & 20.71 & 17.51 \\
\hline $18 X-4,100-102$ & 164.71 & 73.73 & & \\
\hline $18 X-4,104-105$ & 164.74 & 78.26 & 8.89 & 12.84 \\
\hline $18 X-4,110-112$ & 164.81 & 70.83 & & \\
\hline $18 X-4,145-150$ & 165.18 & 59.55 & 25.10 & 15.32 \\
\hline $18 X-5,0-5$ & 165.23 & 64.38 & 21.67 & 13.94 \\
\hline $18 X-5,20-22$ & 165.41 & 64.83 & & \\
\hline $18 X-5,45-47$ & 165.66 & 45.00 & 36.59 & 18.40 \\
\hline $18 X-5,50-52$ & 165.71 & 45.08 & & \\
\hline $18 X-5,56-60$ & 165.78 & 51.08 & 30.72 & 18.19 \\
\hline $18 X-5,70-71$ & 165.90 & 60.95 & 20.63 & 18.41 \\
\hline $18 X-5,76-78$ & 165.97 & 54.00 & & \\
\hline $18 X-5,100-102$ & 166.21 & 57.46 & & \\
\hline $18 X-5,106-107$ & 166.26 & 46.08 & 25.36 & 28.55 \\
\hline $18 X-5,110-112$ & 166.31 & 38.67 & & \\
\hline $18 X-5,120-124$ & 166.42 & 54.00 & & \\
\hline $18 X-5,135-136$ & 166.55 & 60.47 & 23.15 & 16.37 \\
\hline $18 X-5,140-142$ & 166.61 & 54.90 & & \\
\hline $18 X-6,17-18$ & 166.87 & 67.00 & 11.74 & 21.25 \\
\hline $18 X-6,20-22$ & 166.91 & 59.17 & & \\
\hline $18 X-6,50-52$ & 167.21 & 45.50 & & \\
\hline $18 X-6,56-60$ & 167.28 & 41.36 & 31.77 & 26.41 \\
\hline $18 X-6,60-62$ & 167.31 & 35.44 & & \\
\hline $18 X-6,70-74$ & 167.42 & 50.00 & & \\
\hline $18 X-6,75-76$ & 167.45 & 61.85 & 8.86 & 29.28 \\
\hline $18 X-6,107-108$ & 167.77 & 84.00 & 8.19 & 7.68 \\
\hline $18 X-6,110-112$ & 167.81 & 79.92 & & \\
\hline $19 X-1,18-19$ & 168.88 & 76.16 & 4.26 & 19.57 \\
\hline $19 X-1,20-22$ & 168.91 & 73.17 & & \\
\hline $19 X-1,45-46$ & 169.15 & 69.62 & 10.32 & 20.05 \\
\hline $19 X-1,50-52$ & 169.21 & 64.67 & & \\
\hline $19 X-1,60-62$ & 169.31 & 60.42 & & \\
\hline $19 X-1,77-78$ & 169.47 & 67.41 & 15.86 & 16.72 \\
\hline $19 X-1,90-94$ & 169.62 & 69.17 & 14.45 & 16.37 \\
\hline $19 X-1,110-112$ & 169.81 & 73.00 & & \\
\hline $19 \times-1,135-136$ & 170.05 & 79.84 & 9.16 & 7.49 \\
\hline
\end{tabular}

APPENDIX (continued).

\begin{tabular}{|c|c|c|c|c|}
\hline $\begin{array}{l}\text { Core, section, } \\
\text { interval }(\mathrm{cm})\end{array}$ & $\begin{array}{l}\text { Depth } \\
\text { (mbsf) }\end{array}$ & $\begin{array}{c}\mathrm{CaCO}_{3} \\
(\%)\end{array}$ & $\begin{array}{l}\text { Opal } \\
(\%)\end{array}$ & $\begin{array}{l}\text { Other } \\
(\%)\end{array}$ \\
\hline $19 X-1,140-142$ & 170.11 & 77.75 & & \\
\hline $19 X-2,17-18$ & 170.37 & 64.50 & 12.03 & 23.46 \\
\hline $19 X-2,20-22$ & 170.41 & 66.17 & & \\
\hline $19 X-2,45-46$ & 170.65 & 69.93 & 10.70 & 19.36 \\
\hline $19 X-2,50-52$ & 170.71 & 64.75 & & \\
\hline $19 X-2,60-62$ & 170.81 & 66.67 & & \\
\hline $19 X-2,75-76$ & 170.95 & 62.75 & 8.25 & 28.99 \\
\hline $19 X-2,90-94$ & 171.10 & 51.59 & 23.91 & 24.49 \\
\hline $19 X-2,100-102$ & 171.21 & 58.05 & & \\
\hline $19 X-2,110-112$ & 171.31 & 58.92 & & \\
\hline $19 X-2,120-124$ & 171.42 & 55.58 & & \\
\hline $19 X-2,135-136$ & 171.55 & 52.12 & 24.69 & 23.18 \\
\hline $19 X-2,140-142$ & 171.61 & 62.42 & & \\
\hline $19 X-3,14-15$ & 171.84 & 58.46 & 15.39 & 26.14 \\
\hline $19 X-3,20-22$ & 171.91 & 50.92 & & \\
\hline $19 X-3,45-46$ & 172.15 & 59.19 & 23.88 & 16.92 \\
\hline $19 X-3,50-52$ & 172.21 & 55.42 & & \\
\hline $19 X-3,60-62$ & 172.31 & 58.67 & & \\
\hline $19 X-3,76-77$ & 172.46 & 64.62 & 14.58 & 20.79 \\
\hline $19 X-3,90-94$ & 172.62 & 68.11 & 5.82 & 26.06 \\
\hline $19 X-3,100-102$ & 172.71 & 72.47 & & \\
\hline $19 X-3,110-112$ & 172.81 & 62.42 & & \\
\hline $19 X-3,120-124$ & 172.92 & 57.75 & & \\
\hline $19 X-3,135-136$ & 173.05 & 62.99 & 19.92 & 17.09 \\
\hline $19 X-3,140-142$ & 173.11 & 54.83 & & \\
\hline $19 X-4,14-15$ & 173.34 & 68.56 & 9.56 & 21.87 \\
\hline $19 X-4,20-22$ & 173.41 & 82.17 & & \\
\hline $19 X-4,45-46$ & 173.65 & 77.82 & 6.34 & 15.83 \\
\hline $19 X-4,50-52$ & 173.71 & 85.92 & & \\
\hline $19 X-4,60-62$ & 173.81 & 82.83 & & \\
\hline $19 X-4,70-74$ & 173.92 & 86.08 & & \\
\hline $19 \times-4,76-77$ & 173.96 & 84.52 & 4.30 & 11.17 \\
\hline $19 X-4,90-94$ & 174.12 & 89.17 & 3.37 & 7.45 \\
\hline $19 X-4,100-102$ & 174.21 & 88.99 & & \\
\hline $19 X-4,110-112$ & 174.31 & 83.75 & & \\
\hline $19 X-4,135-136$ & 174.55 & 77.05 & 7.01 & 15.93 \\
\hline $19 X-4,140-142$ & 174.61 & 73.42 & & \\
\hline $19 \times-5,0-5$ & 174.73 & 82.03 & 5.15 & 12.87 \\
\hline $19 X-5,10-14$ & 174.82 & 73.67 & & \\
\hline $19 X-5,20-22$ & 174.91 & 76.92 & & \\
\hline $19 X-5,45-46$ & 175.15 & 77.22 & 5.02 & 17.75 \\
\hline $19 X-5,50-52$ & 175.21 & 76.75 & & \\
\hline $19 X-5,60-62$ & 175.31 & 72.42 & & \\
\hline $19 X-5,75-76$ & 175.45 & 68.01 & 10.83 & 21.15 \\
\hline $19 X-5,90-94$ & 175.62 & 39.70 & 23.92 & 35.32 \\
\hline $19 X-5,100-102$ & 175.71 & 41.95 & & \\
\hline $19 X-5,110-112$ & 175.81 & 51.00 & & \\
\hline $19 X-5,135-136$ & 176.05 & 63.40 & 16.21 & 20.38 \\
\hline $19 X-5,140-142$ & 176.11 & 57.58 & & \\
\hline $19 X-6,10-14$ & 176.32 & 74.50 & & \\
\hline $19 X-6,14-15$ & 176.34 & 82.43 & 4.86 & 12.70 \\
\hline $19 X-6,20-22$ & 176.41 & 82.42 & & \\
\hline $19 X-6,45-46$ & 176.65 & 77.06 & 9.44 & 13.49 \\
\hline $19 X-6,50-52$ & 176.71 & 80.50 & & \\
\hline $19 X-6,60-62$ & 176.81 & 79.50 & & \\
\hline $19 X-6,75-76$ & 176.95 & 74.43 & 10.53 & 15.03 \\
\hline $19 X-6,90-94$ & 177.12 & 77.43 & 9.82 & 12.74 \\
\hline $19 X-6,100-102$ & 177.21 & 80.56 & & \\
\hline $19 \times-6,110-112$ & 177.31 & 80.83 & & \\
\hline $19 X-6,135-136$ & 177.55 & 71.29 & 11.29 & 17.41 \\
\hline $19 X-6,140-142$ & 177.61 & 65.33 & & \\
\hline $20 X-1,15-16$ & 178.35 & 81.07 & 4.47 & 14.45 \\
\hline $20 \mathrm{X}-1,20-22$ & 178.41 & 76.08 & & \\
\hline $20 X-1,46-48$ & 178.67 & 71.67 & & \\
\hline $20 \mathrm{X}-1,58-62$ & 178.80 & 73.32 & 9.42 & 17.25 \\
\hline $20 \times-1,75-76$ & 178.95 & 75.02 & 9.87 & 15.10 \\
\hline $20 \mathrm{X}-1,80-82$ & 179.01 & 73.83 & & \\
\hline $20 \mathrm{X}-1,100-102$ & 179.21 & 72.39 & & \\
\hline $20 X-1,105-106$ & 179.25 & 70.16 & 13.19 & 16.64 \\
\hline $20 \mathrm{X}-1,110-112$ & 179.31 & 67.66 & & \\
\hline $20 X-1,135-136$ & 179.55 & 71.32 & 7.28 & 21.39 \\
\hline $20 X-1,140-142$ & 179.61 & 65.17 & & \\
\hline $20 X-2,15-16$ & 179.85 & 68.16 & 11.01 & 20.82 \\
\hline $20 \mathrm{X}-2,20-22$ & 179.91 & 75.50 & & \\
\hline $20 X-2,46-48$ & 180.17 & 57.67 & & \\
\hline $20 X-2,58-62$ & 180.30 & 54.24 & 17.96 & 27.79 \\
\hline $20 X-2,75-76$ & 180.45 & 60.70 & 16.01 & 23.28 \\
\hline
\end{tabular}


APPENDIX (continued).

\begin{tabular}{|c|c|c|c|c|}
\hline $\begin{array}{l}\text { Core, section, } \\
\text { interval }(\mathrm{cm})\end{array}$ & $\begin{array}{l}\text { Depth } \\
\text { (mbsf) }\end{array}$ & $\begin{array}{c}\mathrm{CaCO}_{3} \\
(\%)\end{array}$ & $\begin{array}{l}\text { Opal } \\
(\%)\end{array}$ & $\begin{array}{l}\text { Other } \\
(\%)\end{array}$ \\
\hline $20 X-2,80-82$ & 180.51 & 61.00 & & \\
\hline $20 X-2,100-102$ & 180.71 & 72.22 & & \\
\hline $20 X-2,105-106$ & 180.75 & 77.73 & 6.70 & 15.56 \\
\hline $20 \mathrm{X}-2,110-112$ & 180.81 & 80.42 & & \\
\hline $20 \mathrm{X}-2,135-136$ & 181.05 & 66.70 & 6.59 & 26.70 \\
\hline $20 X-2,140-142$ & 181.11 & 63.00 & & \\
\hline $20 X-3,15-16$ & 181.35 & 83.90 & 4.63 & 11.46 \\
\hline $20 \mathrm{X}-3,20-22$ & 181.41 & 85.00 & & \\
\hline $20 X-3,46-48$ & 181.67 & 75.88 & & \\
\hline $20 X-3,58-62$ & 181.80 & 63.25 & 9.35 & 27.39 \\
\hline $20 X-3,75-76$ & 181.95 & 57.79 & 10.89 & 31.31 \\
\hline $20 \mathrm{X}-3,80-82$ & 182.01 & 61.58 & & \\
\hline $20 X-3,90-94$ & 182.12 & 77.67 & & \\
\hline $20 \mathrm{X}-3,100-102$ & 182.21 & 75.81 & & \\
\hline $20 \mathrm{X}-3,105-106$ & 182.25 & 72.66 & 8.89 & 18.44 \\
\hline $20 \mathrm{X}-3,138-139$ & 182.58 & 36.68 & 26.74 & 35.44 \\
\hline $20 X-3,140-142$ & 182.61 & 43.25 & & \\
\hline $20 X-4,15-16$ & 182.85 & 59.28 & 13.13 & 27.58 \\
\hline $20 X-4,20-22$ & 182.91 & 64.42 & & \\
\hline $20 X-4,46-48$ & 183.17 & 78.72 & & \\
\hline $20 X-4,58-62$ & 183.30 & 83.5 & 4.61 & 11.40 \\
\hline $20 X-4,75-76$ & 183.45 & 80.88 & 5.39 & 13.72 \\
\hline $20 X-4,80-82$ & 183.51 & 78.33 & & \\
\hline $20 X-4,90-94$ & 183.62 & 83.92 & & \\
\hline $20 X-4,100-102$ & 183.71 & 85.83 & & \\
\hline $20 \mathrm{X}-4,105-106$ & 183.75 & 87.02 & 3.41 & 9.56 \\
\hline $20 X-4,135-136$ & 184.05 & 82.5 & 4.32 & 12.73 \\
\hline $20 X-4,140-142$ & 184.11 & 79.6 & & \\
\hline $20 X-5,0-5$ & 184.23 & 84.2 & 4.67 & 11.08 \\
\hline $20 X-5,20-22$ & 184.41 & 87.00 & & \\
\hline $20 X-5,35-36$ & 184.55 & 78.86 & 7.35 & 13.78 \\
\hline $20 X-5,46-48$ & 184.67 & 78.83 & & \\
\hline $20 X-5,58-62$ & 184.80 & 83.29 & 5.75 & 10.95 \\
\hline $20 X-5,75-76$ & 184.95 & 75.59 & 9.77 & 14.63 \\
\hline $20 X-5,80-82$ & 185.01 & 68.83 & & \\
\hline $20 X-5,90-94$ & 185.12 & 62.92 & & \\
\hline $20 X-5,100-102$ & 185.21 & 82.23 & & \\
\hline $20 X-5,105-106$ & 185.25 & 83.70 & 5.02 & 11.27 \\
\hline $20 X-5,110-112$ & 185.31 & 84.08 & & \\
\hline $20 X-5,135-136$ & 185.55 & 83.34 & 3.76 & 12.89 \\
\hline $20 X-5,140-142$ & 185.61 & 72.33 & & \\
\hline $20 X-6,15-16$ & 185.85 & 75.04 & 7.70 & 17.25 \\
\hline $20 X-6,20-22$ & 185.91 & 72.83 & & \\
\hline $20 X-6,46-48$ & 186.17 & 75.17 & & \\
\hline $20 X-6,58-62$ & 186.30 & 79.56 & 6.96 & 13.47 \\
\hline $20 X-6,75-76$ & 186.45 & 84.36 & 3.98 & 11.65 \\
\hline $20 X-6,80-82$ & 186.51 & 81.67 & & \\
\hline $20 X-6,90-94$ & 186.62 & 69.42 & & \\
\hline $20 X-6,100-102$ & 186.71 & 77.81 & & \\
\hline $20 X-6,105-106$ & 186.75 & 79.96 & 6.38 & 13.65 \\
\hline $20 X-6,110-112$ & 186.81 & 75.50 & & \\
\hline $20 X-6,135-136$ & 187.05 & 66.86 & 10.25 & 23.23 \\
\hline $20 X-6,140-142$ & 187.11 & 75.6 & & \\
\hline $20 X-7,20-22$ & 187.41 & 75.83 & & \\
\hline $21 X-1,18-22$ & 187.90 & 81.97 & 6.92 & 11.11 \\
\hline $21 X-1,44-45$ & 188.14 & 87.48 & 5.17 & 7.34 \\
\hline $21 X-1,75-76$ & 188.45 & 84.11 & 4.61 & 11.28 \\
\hline $21 X-1,80-82$ & 188.51 & 83.50 & & \\
\hline $21 X-1,100-102$ & 188.71 & 83.07 & & \\
\hline $21 X-1,105-106$ & 188.75 & 85.70 & 2.80 & 11.49 \\
\hline $21 X-1,110-112$ & 188.81 & 84.75 & & \\
\hline $21 X-1,135-136$ & 189.05 & 87.86 & 3.15 & 8.98 \\
\hline $21 X-1,140-142$ & 189.11 & 85.92 & & \\
\hline $21 X-2,18-22$ & 189.40 & 84.95 & 4.96 & 10.08 \\
\hline $21 X-2,44-45$ & 189.64 & 83.75 & 6.33 & 9.91 \\
\hline $21 X-2,45-47$ & 189.66 & 81.33 & & \\
\hline $21 X-2,50-52$ & 189.71 & 83.58 & & \\
\hline $21 X-2,75-76$ & 189.95 & 85.27 & 4.81 & 9.92 \\
\hline $21 X-2,80-82$ & 190.01 & 81.67 & & \\
\hline $21 X-2,100-102$ & 190.21 & 87.74 & & \\
\hline $21 X-2,105-106$ & 190.25 & 87.86 & 3.05 & 9.08 \\
\hline $21 X-2,110-112$ & 190.31 & 85.08 & & \\
\hline $21 X-2,135-136$ & 190.55 & 83.15 & 3.86 & 12.98 \\
\hline $21 X-2,140-142$ & 190.61 & 85.25 & & \\
\hline $21 \mathrm{X}-3,18-22$ & 190.90 & 86.46 & 4.78 & 8.75 \\
\hline $21 X-3,43-44$ & 191.13 & 80.63 & 7.29 & 12.07 \\
\hline $21 X-3,45-47$ & 191.15 & 72.08 & & \\
\hline
\end{tabular}

APPENDIX (continued).

\begin{tabular}{|c|c|c|c|c|}
\hline $\begin{array}{l}\text { Core, section, } \\
\text { interval }(\mathrm{cm})\end{array}$ & $\begin{array}{l}\text { Depth } \\
\text { (mbsf) }\end{array}$ & $\begin{array}{c}\mathrm{CaCO}_{3} \\
(\%)\end{array}$ & $\begin{array}{l}\text { Opal } \\
(\%)\end{array}$ & $\begin{array}{l}\text { Other } \\
(\%)\end{array}$ \\
\hline $21 X-3,75-76$ & 191.45 & 86.16 & 3.87 & 9.96 \\
\hline $21 X-3,80-82$ & 191.51 & 88.50 & & \\
\hline $21 X-3,100-102$ & 191.71 & 81.06 & & \\
\hline $21 X-3,103-104$ & 191.73 & 82.48 & 6.72 & 10.79 \\
\hline $21 X-3,110-112$ & 191.81 & 68.00 & & \\
\hline $21 X-3,145-150$ & 192.18 & 88.51 & 4.38 & 7.10 \\
\hline $21 X-4,0-5$ & 192.22 & 79.92 & 8.97 & 11.10 \\
\hline $21 X-4,18-22$ & 192.40 & 73.16 & 12.53 & 14.30 \\
\hline $21 X-4,44-45$ & 192.64 & 68.40 & 16.80 & 14.79 \\
\hline $21 X-4,45-47$ & 192.65 & 62.17 & & \\
\hline $21 X-4,50-52$ & 192.71 & 59.83 & & \\
\hline $21 X-4,70-72$ & 192.91 & 71.47 & & \\
\hline $21 X-4,73-74$ & 192.93 & 80.72 & 8.16 & 11.11 \\
\hline $21 X-4,80-82$ & 193.01 & 60.25 & & \\
\hline $22 X-1,15-16$ & 197.35 & 71.38 & 8.22 & 20.39 \\
\hline $22 X-1,20-22$ & 197.41 & 75.92 & & \\
\hline $22 X-1,45-46$ & 197.65 & 67.76 & 9.99 & 22.25 \\
\hline $22 X-1,50-52$ & 197.71 & 63.00 & & \\
\hline $22 X-1,71-75$ & 197.93 & 64.54 & 12.43 & 23.02 \\
\hline $22 X-1,81-83$ & 198.02 & 64.50 & & \\
\hline $22 X-1,100-102$ & 198.21 & 68.47 & & \\
\hline $22 X-1,108-109$ & 198.28 & 69.62 & 9.90 & 20.47 \\
\hline $22 \mathrm{X}-1,110-112$ & 198.31 & 64.25 & & \\
\hline $22 X-1,135-136$ & 198.55 & 68.00 & 10.70 & 21.29 \\
\hline $22 \mathrm{X}-1,139-141$ & 198.60 & 72.25 & & \\
\hline $22 X-2,17-18$ & 198.87 & 69.77 & 10.08 & 20.14 \\
\hline $22 X-2,20-22$ & 198.91 & 69.17 & & \\
\hline $22 X-2,45-46$ & 199.15 & 57.94 & 15.80 & 26.25 \\
\hline $22 \mathrm{X}-2,50-52$ & 199.21 & 57.50 & & \\
\hline $22 X-2,69-73$ & 199.41 & 63.16 & 14.03 & 22.80 \\
\hline $22 X-2,80-82$ & 199.51 & 71.33 & & \\
\hline $22 X-2,100-102$ & 199.71 & 60.46 & & \\
\hline $22 \mathrm{X}-2,105-106$ & 199.75 & 69.74 & 9.14 & 21.11 \\
\hline $22 X-2,110-112$ & 199.81 & 69.25 & & \\
\hline $22 X-2,135-136$ & 200.05 & 80.23 & 7.61 & 12.15 \\
\hline $22 X-2,139-141$ & 200.10 & 76.25 & & \\
\hline $22 X-3,17-18$ & 200.37 & 61.61 & 14.46 & 23.92 \\
\hline $22 X-3,20-22$ & 200.41 & 47.75 & & \\
\hline $22 X-3,45-46$ & 200.65 & 69.15 & 8.67 & 22.17 \\
\hline $22 X-3,50-52$ & 200.71 & 82.00 & & \\
\hline $22 X-3,69-73$ & 200.91 & 77.03 & 9.38 & 13.58 \\
\hline $22 \mathrm{X}-3,81-83$ & 201.02 & 70.17 & & \\
\hline $22 X-3,100-102$ & 201.21 & 51.79 & & \\
\hline $22 \times-3,108-109$ & 201.28 & 40.73 & 27.02 & 32.91 \\
\hline $22 X-3,110-112$ & 201.31 & 41.08 & & \\
\hline $22 \times-3,135-136$ & 201.55 & 59.55 & 13.06 & 27.38 \\
\hline $22 \mathrm{X}-3,140-142$ & 201.61 & 56.83 & & \\
\hline $22 X-4,17-18$ & 201.87 & 61.10 & 18.53 & 20.36 \\
\hline $22 X-4,20-22$ & 201.91 & 56.75 & & \\
\hline $22 X-4,45-46$ & 202.15 & 56.11 & 16.05 & 27.83 \\
\hline $22 \mathrm{X}-4,50-52$ & 202.21 & 57.25 & & \\
\hline $22 X-4,68-72$ & 202.40 & 65.34 & 13.27 & 21.38 \\
\hline $22 X-4,81-83$ & 202.51 & 75.08 & & \\
\hline $22 X-4,100-102$ & 202.71 & 77.81 & & \\
\hline $22 X-4,105-106$ & 202.75 & 67.42 & 11.16 & 21.41 \\
\hline $22 \times-4,110-112$ & 202.81 & 58.59 & & \\
\hline $22 \times-4,135-136$ & 203.05 & 41.31 & 34.20 & 24.48 \\
\hline $22 X-4,139-141$ & 203.11 & 33.50 & & \\
\hline $22 \times-5,0-5$ & 203.23 & 49.53 & 28.27 & 22.19 \\
\hline $22 X-5,20-22$ & 203.41 & 50.67 & & \\
\hline $22 X-5,68-72$ & 203.90 & 72.98 & 12.16 & 14.85 \\
\hline $22 X-5,81-83$ & 204.02 & 65.00 & & \\
\hline $22 X-5,110-112$ & 204.31 & 65.67 & & \\
\hline $22 X-5,139-141$ & 204.61 & 74.08 & & \\
\hline $23 X-1,15-16$ & 206.85 & 72.47 & 6.00 & 21.52 \\
\hline $23 \mathrm{X}-1,20-22$ & 206.91 & 71.00 & & \\
\hline $23 X-1,45-46$ & 207.15 & 81.58 & 5.20 & 13.21 \\
\hline $23 X-1,50-52$ & 207.21 & 79.67 & & \\
\hline $23 X-1,68-72$ & 207.40 & 81.74 & 4.70 & 13.55 \\
\hline $23 X-1,80-82$ & 207.51 & 77.58 & & \\
\hline $23 \mathrm{X}-1,100-102$ & 207.71 & 82.90 & & \\
\hline $23 \mathrm{X}-1,105-106$ & 207.75 & 81.79 & 4.37 & 13.83 \\
\hline $23 \mathrm{X}-1,110-112$ & 207.81 & 71.83 & & \\
\hline $23 \mathrm{X}-1,135-136$ & 208.05 & 75.62 & 6.14 & 18.24 \\
\hline $23 \mathrm{X}-1,140-142$ & 208.11 & 71.83 & & \\
\hline $23 \mathrm{X}-2,15-16$ & 208.35 & 71.18 & 6.59 & 22.22 \\
\hline $23 \mathrm{X}-2,20-22$ & 208.41 & 80.42 & & \\
\hline
\end{tabular}


APPENDIX (continued).

\begin{tabular}{|c|c|c|c|c|}
\hline $\begin{array}{l}\text { Core, section, } \\
\text { interval }(\mathrm{cm})\end{array}$ & $\begin{array}{l}\text { Depth } \\
\text { (mbsf) }\end{array}$ & $\begin{array}{c}\mathrm{CaCO}_{3} \\
(\%)\end{array}$ & $\begin{array}{l}\text { Opal } \\
(\%)\end{array}$ & $\begin{array}{l}\text { Other } \\
(\%)\end{array}$ \\
\hline $23 \mathrm{X}-2,45-46$ & 208.65 & 76.01 & 7.36 & 16.62 \\
\hline $23 X-2,50-52$ & 208.71 & 73.42 & & \\
\hline $23 X-2,68-72$ & 208.90 & 75.21 & 6.69 & 18.09 \\
\hline $23 \mathrm{X}-2,80-82$ & 209.01 & 71.25 & & \\
\hline $23 \mathrm{X}-2,100-102$ & 209.21 & 74.98 & & \\
\hline $23 X-2,105-106$ & 209.25 & 72.86 & 7.26 & 19.87 \\
\hline $23 X-2,135-136$ & 209.55 & 74.39 & 6.75 & 18.86 \\
\hline $23 X-2,140-142$ & 209.61 & 74.58 & & \\
\hline $23 X-3,0-5$ & 209.73 & 79.00 & 6.49 & 14.50 \\
\hline $23 \mathrm{X}-3,20-22$ & 209.91 & 75.25 & & \\
\hline $23 X-3,45-46$ & 210.15 & 81.54 & 4.67 & 13.78 \\
\hline $23 X-3,50-52$ & 210.21 & 78.58 & & \\
\hline $23 X-3,68-72$ & 210.40 & 75.09 & 9.17 & 15.73 \\
\hline $23 \mathrm{X}-3,80-82$ & 210.51 & 70.02 & & \\
\hline $23 \mathrm{X}-3,100-102$ & 210.71 & 77.81 & & \\
\hline $23 X-3,107-108$ & 210.77 & 78.71 & 4.30 & 16.98 \\
\hline $23 \mathrm{X}-3,110-112$ & 210.81 & 78.00 & & \\
\hline $23 \mathrm{X}-3,135-136$ & 211.05 & 78.39 & 7.00 & 14.60 \\
\hline $23 X-3,140-142$ & 211.11 & 74.83 & & \\
\hline $23 X-4,15-16$ & 211.35 & 76.07 & 6.16 & 17.76 \\
\hline $23 X-4,20-22$ & 211.41 & 67. & & \\
\hline $23 X-4,45-46$ & 211.65 & 67. & 7.87 & 24.34 \\
\hline $23 \mathrm{X}-4,50-52$ & 211.71 & 67.83 & & \\
\hline $23 X-4,68-72$ & 211.90 & 74.52 & 6.95 & 18.52 \\
\hline $23 X-4,80-82$ & 212.01 & 71.58 & & \\
\hline $23 \mathrm{X}-4,100-102$ & 212.21 & 69.72 & & \\
\hline $23 \mathrm{X}-4,105-106$ & 212.25 & 71.76 & 5.15 & 23.08 \\
\hline $23 X-4,110-112$ & 212.31 & 75.92 & & \\
\hline $23 X-4,135-136$ & 212.5 & 81.99 & 4.99 & 13.01 \\
\hline $23 X-4,140-142$ & 212.6 & 76.08 & & \\
\hline $23 X-5,15-16$ & 212.85 & 81.45 & 3.42 & 15.13 \\
\hline $23 \mathrm{X}-5,20-22$ & 212.91 & 77.25 & & \\
\hline $23 X-5,45-46$ & 213.15 & 77.36 & 5.36 & 17.28 \\
\hline $23 X-5,47-49$ & 213.18 & 51.6 & & \\
\hline $23 X-5,68-72$ & 213.40 & 66.92 & 10.17 & 22.90 \\
\hline $23 X-5,80-82$ & 213.51 & 71.25 & & \\
\hline $23 \mathrm{X}-5,100-102$ & 213.71 & 62.72 & & \\
\hline $23 X-5,104-105$ & 213.74 & 55.94 & 20.22 & 23.84 \\
\hline $23 X-5,135-136$ & 214.05 & 69.49 & 6.78 & 23.72 \\
\hline $23 X-5,140-142$ & 214.11 & 73.67 & & \\
\hline $23 \mathrm{X}-6,20-22$ & 214.41 & 75.42 & & \\
\hline $24 X-1,15-16$ & 216.35 & 83.20 & 5.62 & 11.17 \\
\hline $24 \mathrm{X}-1,20-22$ & 216.41 & 83.92 & & \\
\hline $24 X-1,45-46$ & 216.65 & 81.43 & 5.85 & 12.71 \\
\hline $24 X-1,50-52$ & 216.71 & 81.75 & & \\
\hline $24 X-1,58-62$ & 216.80 & 79.60 & 6.02 & 14.37 \\
\hline $24 X-1,88-90$ & 217.09 & 75.25 & & \\
\hline $24 X-1,106-107$ & 217.26 & 70.89 & 10.09 & 19.01 \\
\hline $24 X-1,110-112$ & 217.31 & 72.25 & & \\
\hline $24 X-1,135-136$ & 217.55 & 70.98 & 7.96 & 21.05 \\
\hline $24 X-1,140-142$ & 217.61 & 71.67 & & \\
\hline $24 X-2,15-16$ & 217.85 & 74.20 & 9.27 & 16.52 \\
\hline $24 \mathrm{X}-2,20-22$ & 217.91 & 79.08 & & \\
\hline $24 X-2,45-46$ & 218.15 & 57.35 & 14.09 & 28.55 \\
\hline $24 X-2,50-52$ & 218.21 & 70.00 & & \\
\hline $24 \mathrm{X}-2,58-62$ & 218.30 & 49.02 & 18.82 & 32.15 \\
\hline $24 X-2,82-84$ & 218.53 & 63.22 & & \\
\hline $24 X-2,88-90$ & 218.59 & 63.83 & & \\
\hline $24 X-2,110-112$ & 218.81 & 55.58 & & \\
\hline $24 X-2,121-126$ & 218.93 & 82.00 & 4.61 & 13.38 \\
\hline $24 X-2,135-136$ & 219.05 & 54.06 & 12.19 & 33.74 \\
\hline $24 X-2,140-142$ & 219.11 & 43.25 & & \\
\hline $24 X-3,15-16$ & 219.35 & 57.33 & 12.20 & 30.46 \\
\hline $24 \mathrm{X}-3,20-22$ & 219.41 & 46.25 & & \\
\hline $24 X-3,50-52$ & 219.71 & 14.25 & & \\
\hline $24 X-3,58-62$ & 219.80 & 5.27 & 23.82 & 71.17 \\
\hline $24 X-3,75-76$ & 219.95 & 37.30 & 15.96 & 46.73 \\
\hline $24 X-3,82-84$ & 220.03 & 57.80 & & \\
\hline $24 X-3,88-90$ & 220.09 & 55.17 & & \\
\hline $24 \mathrm{X}-3,102-103$ & 220.22 & 49.49 & 14.04 & 36.46 \\
\hline $24 \mathrm{X}-3,110-112$ & 220.31 & 38.92 & & \\
\hline $24 X-3,137-138$ & 220.57 & 50.66 & 13.74 & 35.59 \\
\hline $24 X-3,140-142$ & 220.61 & 43.25 & & \\
\hline $24 X-4,15-16$ & 220.85 & 2.24 & 29.96 & 67.94 \\
\hline $24 X-4,20-22$ & 220.91 & 0.12 & & \\
\hline $24 X-4,45-46$ & 221.15 & 24.72 & 32.15 & 43.12 \\
\hline $24 X-4,50-52$ & 221.21 & 73.83 & & \\
\hline
\end{tabular}

APPENDIX (continued).

\begin{tabular}{lcccc}
\hline $\begin{array}{c}\text { Core, section, } \\
\text { interval (cm) }\end{array}$ & $\begin{array}{c}\text { Depth } \\
\text { (mbsf) }\end{array}$ & $\begin{array}{c}\mathrm{CaCO}_{3} \\
(\%)\end{array}$ & $\begin{array}{c}\text { Opal } \\
(\%)\end{array}$ & $\begin{array}{c}\text { Other } \\
(\%)\end{array}$ \\
\hline $24 \mathrm{X}-4,58-62$ & 221.30 & 84.11 & 4.74 & 11.14 \\
$24 \mathrm{X}-4,82-84$ & 221.53 & 35.78 & & \\
$24 \mathrm{X}-4,88-90$ & 221.59 & 26.33 & & \\
$24 \mathrm{X}-4,106-107$ & 221.76 & 26.56 & 30.00 & 43.43 \\
$24 \mathrm{X}-4,110-112$ & 221.81 & 24.83 & & \\
$24 \mathrm{X}-4,135-136$ & 222.05 & 61.41 & 13.91 & 24.67 \\
$24 \mathrm{X}-4,140-142$ & 222.11 & 56.00 & & \\
$24 \mathrm{X}-5,15-16$ & 222.35 & 63.85 & 9.55 & 26.59 \\
$24 \mathrm{X}-5,20-22$ & 222.41 & 59.58 & & \\
$24 \mathrm{X}-5,45-46$ & 222.65 & 63.02 & 11.55 & 25.42 \\
$24 \mathrm{X}-5,50-52$ & 222.71 & 59.50 & & \\
$24 \mathrm{X}-5,58-62$ & 222.80 & 49.62 & 15.71 & 34.66 \\
$24 \mathrm{X}-5,82-84$ & 223.03 & 50.71 & & \\
$24 \mathrm{X}-5,88-90$ & 223.09 & 68.08 & & \\
$24 \mathrm{X}-5,106-107$ & 223.26 & 73.67 & 6.90 & 19.42 \\
$24 \mathrm{X}-5,110-112$ & 223.31 & 67.50 & & \\
$24 \mathrm{X}-5,130-132$ & 223.51 & 43.98 & & \\
$24 \mathrm{X}-5,134-135$ & 223.54 & 55.33 & 15.47 & 29.20
\end{tabular}

$24 \mathrm{X}-5,140-142 \quad 223.61 \quad 57.50$

$24 \mathrm{X}-6,20-22 \quad 223.91 \quad 31.25$

$25 \mathrm{X}-1,15-16 \quad 225.86 \quad 61.10$

$25 \mathrm{X}-1,20-22 \quad 225.91 \quad 63.00$

$25 \mathrm{X}-1,44-45 \quad 226.15 \quad 57.60$

$25 \mathrm{X}-1,70-74 \quad 226.41 \quad 57.20$

$25 \mathrm{X}-1,80-82 \quad 226.51 \quad 61.41$

$25 \mathrm{X}-1,106-107 \quad 226.77 \quad 49.00$

$25 \mathrm{X}-1,110-112 \quad 226.81 \quad 43.83$

$25 \mathrm{X}-1,130-132 \quad 227.01 \quad 43.95$

$25 X-1,135-136 \quad 227.06 \quad 51.90$

$25 \mathrm{X}-1,140-142 \quad 227.11 \quad 45.33$

$25 \mathrm{X}-2,15-16 \quad 227.36 \quad 84.40$

25X-2, 20-22 $227.41 \quad 85.08$

$25 X-2,45-46 \quad 227.66 \quad 87.50$

$25 \mathrm{X}-2,50-52 \quad 227.71 \quad 90.92$

$25 \mathrm{X}-2,70-74 \quad 227.91 \quad 75.00$

$25 \mathrm{X}-2,80-82 \quad 228.01 \quad 67.25$

$25 \mathrm{X}-2,106-107 \quad 228.27 \quad 65.80$

$25 \mathrm{X}-2,110-112 \quad 228.31 \quad 50.08$

$25 \mathrm{X}-2,130-132 \quad 228.51 \quad 1.00$

$25 \mathrm{X}-2,135-136 \quad 228.56 \quad 4.00$

$25 \mathrm{X}-2,140-142 \quad 228.61 \quad 9.33$

$25 \mathrm{X}-3,15-16 \quad 228.86 \quad 66.00$

$25 \mathrm{X}-3,20-22 \quad 228.91 \quad 58.08$

$25 \mathrm{X}-3,44-45 \quad 229.15 \quad 46.50$

$25 X-3,47-49 \quad 229.18 \quad 21.33$

$25 X-3,70-74 \quad 229.41 \quad 49.00$

$25 X-3,80-82 \quad 229.51 \quad 61.08$

$25 \mathrm{X}-3,90-92 \quad 229.61 \quad 75.39$

$25 X-3,108-109 \quad 229.79 \quad 50.63$

$25 \mathrm{X}-3,110-112 \quad 229.81 \quad 76.08$

$25 X-3,135-136 \quad 230.06 \quad 75.70$

$25 X-3,140-142 \quad 230.11 \quad 75.42$

$25 X-4,0-5 \quad 230.21 \quad 83.10$

$25 \mathrm{X}-4,20-22 \quad 230.41 \quad 82.00$

$25 \mathrm{X}-4,44-45 \quad 230.65 \quad 75.90$

$\begin{array}{lll}25 X-4,47-49 & 230.68 & 73.00\end{array}$

$25 \mathrm{X}-4,70-74 \quad 230.91 \quad 57.20$

$25 \mathrm{X}-4,80-82 \quad 231.01 \quad 51.83$

$25 \mathrm{X}-4,90-94 \quad 231.11 \quad 41.20$

$25 \mathrm{X}-4,108-109 \quad 231.29 \quad 46.50$

$25 \mathrm{X}-4,110-112 \quad 231.31 \quad 41.42$

$25 \mathrm{X}-4,140-150 \quad 231.61 \quad 79.10$

$25 X-5,15-16 \quad 231.86 \quad 76.20$

$25 X-5,44-45 \quad 232.15 \quad 57.50$

$25 \mathrm{X}-5,47-49 \quad 232.18 \quad 53.83$

$25 \mathrm{X}-5,50-52 \quad 232.21 \quad 57.88$

$25 \mathrm{X}-5,70-74 \quad 232.41 \quad 64.70$

$25 X-5,106-107 \quad 232.77 \quad 76.00$

$25 \mathrm{X}-5,110-112 \quad 232.81 \quad 73.58$

$25 X-5,135-136 \quad 233.06 \quad 77.30$

$25 \mathrm{X}-5,140-142 \quad 233.11 \quad 69.42$

$\begin{array}{lll}25 \mathrm{X}-6,15-16 & 233.36 & 48.90\end{array}$

$25 \mathrm{X}-6,20-22 \quad 233.41 \quad 47.42$

$25 X-6,45-46 \quad 233.66 \quad 39.82$

$25 \mathrm{X}-6,47-49 \quad 233.68 \quad 46.67$

$25 \mathrm{X}-6,50-52 \quad 233.71 \quad 39.53$

$25 X-6,70-74 \quad 233.91 \quad 45.04$ 
APPENDIX (continued).

\begin{tabular}{|c|c|c|c|c|}
\hline $\begin{array}{l}\text { Core, section, } \\
\text { interval }(\mathrm{cm})\end{array}$ & $\begin{array}{l}\text { Depth } \\
\text { (mbsf) }\end{array}$ & $\begin{array}{c}\mathrm{CaCO}_{3} \\
(\%)\end{array}$ & $\begin{array}{l}\text { Opal } \\
(\%)\end{array}$ & $\begin{array}{l}\text { Other } \\
(\%)\end{array}$ \\
\hline $25 \mathrm{X}-6,80-82$ & 234.01 & 40.25 & & \\
\hline $25 X-6,96-97$ & 234.17 & 44.80 & & \\
\hline \multicolumn{5}{|l|}{ 114-704B- } \\
\hline $1 \mathrm{H}-1,10-12$ & 0.11 & 85.17 & & \\
\hline $1 \mathrm{H}-1,30-32$ & 0.31 & 49.42 & & \\
\hline $1 \mathrm{H}-1,50-52$ & 0.51 & 41.25 & & \\
\hline $1 \mathrm{H}-1,60-62$ & 0.61 & 48.28 & & \\
\hline $1 \mathrm{H}-1,89-91$ & 0.90 & 64.00 & & \\
\hline $1 \mathrm{H}-1,90-92$ & 0.91 & 63.33 & & \\
\hline $1 \mathrm{H}-1,120-122$ & 1.21 & 63.83 & & \\
\hline $1 \mathrm{H}-1,130-132$ & 1.31 & 66.33 & & \\
\hline $1 \mathrm{H}-2,10-12$ & 1.61 & 50.67 & & \\
\hline $1 \mathrm{H}-2,30-32$ & 1.81 & 71.00 & & \\
\hline $1 \mathrm{H}-2,50-52$ & 2.01 & 82.67 & & \\
\hline $1 \mathrm{H}-2,60-62$ & 2.11 & 75.25 & & \\
\hline $1 \mathrm{H}-2,89-91$ & 2.40 & 15.17 & & \\
\hline $1 \mathrm{H}-2,90-92$ & 2.41 & 31.67 & & \\
\hline $1 \mathrm{H}-2,110-112$ & 2.60 & 20.02 & & \\
\hline $1 \mathrm{H}-2,120-122$ & 2.71 & 13.92 & & \\
\hline $1 \mathrm{H}-2,130-132$ & 2.81 & 44.83 & & \\
\hline $1 \mathrm{H}-3,10-12$ & 3.11 & 63.83 & & \\
\hline $1 \mathrm{H}-3,44-46$ & 3.45 & 50.50 & & \\
\hline $1 \mathrm{H}-3,50-52$ & 3.51 & 50.50 & & \\
\hline $1 \mathrm{H}-3,90-92$ & 3.91 & 34.08 & & \\
\hline $1 \mathrm{H}-3,101-103$ & 4.02 & 44.25 & & \\
\hline $1 \mathrm{H}-3,130-132$ & 4.31 & 55.67 & & \\
\hline $1 \mathrm{H}-4,10-12$ & 4.61 & 56.08 & & \\
\hline $1 \mathrm{H}-4,50-52$ & 5.01 & 50.75 & & \\
\hline $1 \mathrm{H}-4,73-75$ & 5.24 & 54.29 & & \\
\hline $1 \mathrm{H}-4,90-92$ & 5.41 & 42.25 & & \\
\hline $1 \mathrm{H}-4,110-112$ & 5.60 & 38.45 & & \\
\hline $1 \mathrm{H}-4,130-132$ & 5.81 & 52.50 & & \\
\hline $1 \mathrm{H}-4,141-143$ & 5.92 & 67.50 & & \\
\hline $1 \mathrm{H}-5,10-12$ & 6.11 & 92.08 & & \\
\hline $1 \mathrm{H}-5,19-21$ & 6.20 & 94.83 & & \\
\hline $1 \mathrm{H}-5,44-46$ & 6.45 & 94.67 & & \\
\hline $1 \mathrm{H}-5,50-52$ & 6.51 & 94.58 & & \\
\hline $2 \mathrm{H}-1,7-9$ & 6.78 & 92.00 & & \\
\hline $2 \mathrm{H}-1,10-12$ & 6.81 & 78.42 & & \\
\hline $2 \mathrm{H}-1,42-44$ & 7.11 & 48.00 & & \\
\hline $2 \mathrm{H}-1,50-52$ & 7.21 & 53.50 & & \\
\hline $2 \mathrm{H}-1,90-92$ & 7.61 & 91.42 & & \\
\hline $2 \mathrm{H}-1,107-109$ & 7.78 & 93.58 & & \\
\hline $2 \mathrm{H}-1,130-132$ & 8.01 & 88.75 & & \\
\hline $2 \mathrm{H}-1,142-144$ & 8.13 & 11.00 & & \\
\hline $2 \mathrm{H}-2,10-12$ & 8.31 & 12.58 & & \\
\hline $2 \mathrm{H}-2,50-52$ & 8.71 & 10.00 & & \\
\hline $2 \mathrm{H}-2,60-62$ & 8.81 & 14.08 & & \\
\hline $2 \mathrm{H}-2,90-92$ & 9.11 & 27.58 & & \\
\hline $2 \mathrm{H}-2,121-123$ & 9.42 & 43.58 & & \\
\hline $2 \mathrm{H}-2,130-132$ & 9.51 & 11.58 & & \\
\hline $2 \mathrm{H}-3,10-12$ & 9.81 & 8.25 & & \\
\hline $2 \mathrm{H}-3,17-19$ & 9.88 & 10.50 & & \\
\hline $2 \mathrm{H}-3,50-52$ & 10.21 & 41.00 & & \\
\hline $2 \mathrm{H}-3,61-63$ & 10.32 & 59.08 & & \\
\hline $2 \mathrm{H}-3,90-92$ & 10.61 & 44.83 & & \\
\hline $2 \mathrm{H}-3,102-104$ & 10.71 & 57.73 & & \\
\hline $2 \mathrm{H}-3,110-112$ & 10.81 & 61.47 & & \\
\hline $2 \mathrm{H}-3,130-132$ & 11.01 & 31.00 & & \\
\hline $2 \mathrm{H}-3,139-141$ & 11.10 & 77.33 & & \\
\hline $2 \mathrm{H}-4,16-18$ & 11.37 & 44.83 & & \\
\hline $2 \mathrm{H}-4,55-57$ & 11.76 & 46.08 & & \\
\hline $2 \mathrm{H}-4,90-92$ & 12.11 & 63.25 & & \\
\hline $2 \mathrm{H}-4,98-100$ & 12.19 & 68.08 & & \\
\hline $2 \mathrm{H}-4,130-132$ & 12.51 & 64.75 & & \\
\hline $2 \mathrm{H}-4,137-139$ & 12.58 & 55.08 & & \\
\hline $2 \mathrm{H}-5,10-12$ & 12.81 & 16.75 & & \\
\hline $2 \mathrm{H}-5,14-16$ & 12.85 & 19.25 & & \\
\hline $2 \mathrm{H}-5,50-52$ & 13.21 & 27.75 & & \\
\hline $2 \mathrm{H}-5,54-56$ & 13.25 & 29.67 & & \\
\hline $2 \mathrm{H}-5,90-92$ & 13.61 & 45.58 & & \\
\hline $2 \mathrm{H}-5,96-98$ & 13.67 & 48.83 & & \\
\hline $2 \mathrm{H}-5,110-112$ & 13.81 & 47.12 & & \\
\hline $2 \mathrm{H}-5,130-132$ & 14.01 & 28.50 & & \\
\hline $2 \mathrm{H}-5,136-138$ & 14.07 & 34.67 & & \\
\hline $2 \mathrm{H}-6,10-12$ & 14.31 & 48.58 & & \\
\hline
\end{tabular}

APPENDIX (continued).

\begin{tabular}{|c|c|c|c|c|}
\hline $\begin{array}{l}\text { Core, section, } \\
\text { interval }(\mathrm{cm})\end{array}$ & $\begin{array}{l}\text { Depth } \\
\text { (mbsf) }\end{array}$ & $\begin{array}{c}\mathrm{CaCO}_{3} \\
(\%)\end{array}$ & $\begin{array}{l}\text { Opal } \\
(\%)\end{array}$ & $\begin{array}{l}\text { Other } \\
(\%)\end{array}$ \\
\hline $3 \mathrm{H}-1,10-12$ & 16.31 & 43.83 & & \\
\hline $3 \mathrm{H}-1,15-1-6$ & 16.35 & 51.69 & 36.14 & 12.16 \\
\hline $3 \mathrm{H}-1,20-22$ & 16.40 & 51.08 & & \\
\hline $3 \mathrm{H}-1,45-46$ & 16.65 & 60.89 & 22.37 & 16.73 \\
\hline $3 \mathrm{H}-1,50-52$ & 16.71 & 60.42 & & \\
\hline $3 \mathrm{H}-1,60-62$ & 16.81 & 62.75 & & \\
\hline $3 \mathrm{H}-1,75-76$ & 16.95 & 66.99 & 16.52 & 16.48 \\
\hline $3 \mathrm{H}-1,90-92$ & 17.11 & 64.33 & & \\
\hline $3 \mathrm{H}-1,94-96$ & 17.14 & 66.00 & & \\
\hline $3 \mathrm{H}-1,105-106$ & 17.25 & 66.85 & 14.85 & 18.29 \\
\hline $3 \mathrm{H}-1,130-132$ & 17.51 & 66.83 & & \\
\hline $3 \mathrm{H}-1,135-136$ & 17.55 & 66.76 & 15.63 & 17.60 \\
\hline $3 \mathrm{H}-1,140-142$ & 17.61 & 58.00 & & \\
\hline $3 \mathrm{H}-2,15-16$ & 17.85 & 55.00 & 28.24 & 16.75 \\
\hline $3 \mathrm{H}-2,20-22$ & 17.90 & 55.58 & & \\
\hline $3 \mathrm{H}-2,45-46$ & 18.15 & 52.51 & 31.77 & 15.71 \\
\hline $3 \mathrm{H}-2,50-52$ & 18.21 & 45.42 & & \\
\hline $3 \mathrm{H}-2,60-62$ & 18.31 & 58.42 & & \\
\hline $3 \mathrm{H}-2,75-76$ & 18.45 & 49.75 & 30.81 & 19.43 \\
\hline $3 \mathrm{H}-2,90-92$ & 18.61 & 46.58 & & \\
\hline $3 \mathrm{H}-2,94-96$ & 18.64 & 45.58 & & \\
\hline $3 \mathrm{H}-2,105-106$ & 18.75 & 47.94 & 32.70 & 19.35 \\
\hline $3 \mathrm{H}-2,110-112$ & 18.80 & 37.28 & & \\
\hline $3 \mathrm{H}-2,135-136$ & 19.05 & 51.12 & 30.16 & 18.71 \\
\hline $3 \mathrm{H}-2,140-142$ & 19.11 & 54.75 & & \\
\hline $3 \mathrm{H}-3,10-12$ & 19.31 & 48.58 & & \\
\hline $3 \mathrm{H}-3,15-16$ & 19.35 & 50.46 & 31.10 & 18.43 \\
\hline $3 \mathrm{H}-3,20-22$ & 19.40 & 38.83 & & \\
\hline $3 \mathrm{H}-3,45-46$ & 19.65 & 47.06 & 34.85 & 18.09 \\
\hline $3 \mathrm{H}-3,50-52$ & 19.71 & 45.25 & & \\
\hline $3 \mathrm{H}-3,60-62$ & 19.81 & 38.92 & & \\
\hline $3 \mathrm{H}-3,75-76$ & 19.95 & 50.40 & 36.10 & 13.49 \\
\hline $3 \mathrm{H}-3,90-92$ & 20.11 & 51.17 & & \\
\hline $3 \mathrm{H}-3,94-96$ & 20.14 & 50.92 & & \\
\hline $3 \mathrm{H}-3,105-106$ & 20.25 & 59.52 & 25.77 & 14.71 \\
\hline $3 \mathrm{H}-3,130-132$ & 20.51 & 59.67 & & \\
\hline $3 \mathrm{H}-3,135-136$ & 20.55 & 59.78 & 22.97 & 17.24 \\
\hline $3 \mathrm{H}-3,140-142$ & 20.61 & 59.67 & & \\
\hline $3 \mathrm{H}-4,10-12$ & 20.81 & 56.50 & & \\
\hline $3 \mathrm{H}-4,15-16$ & 20.85 & 55.45 & 28.65 & 15.89 \\
\hline $3 \mathrm{H}-4,20-22$ & 20.90 & 45.75 & & \\
\hline $3 \mathrm{H}-4,45-46$ & 21.15 & 53.18 & 30.60 & 16.21 \\
\hline $3 \mathrm{H}-4,50-52$ & 21.21 & 57.25 & & \\
\hline $3 \mathrm{H}-4,60-62$ & 21.31 & 44.37 & & \\
\hline $3 \mathrm{H}-4,75-76$ & 21.45 & 55.59 & 31.40 & 13.00 \\
\hline $3 \mathrm{H}-4,90-92$ & 21.61 & 55.17 & & \\
\hline $3 \mathrm{H}-4,94-96$ & 21.64 & 54.42 & & \\
\hline $3 \mathrm{H}-4,105-106$ & 21.75 & 58.05 & 29.06 & 12.88 \\
\hline $3 \mathrm{H}-4,110-112$ & 21.80 & 61.30 & & \\
\hline $3 \mathrm{H}-4,130-132$ & 22.01 & 52.92 & & \\
\hline $3 \mathrm{H}-4,135-136$ & 22.05 & 54.52 & 27.70 & 17.78 \\
\hline $3 \mathrm{H}-4,140-142$ & 22.11 & 56.08 & & \\
\hline $3 \mathrm{H}-5,10-12$ & 22.31 & 51.08 & & \\
\hline $3 \mathrm{H}-5,15-16$ & 22.35 & 52.17 & 32.32 & 15.51 \\
\hline $3 \mathrm{H}-5,20-22$ & 22.40 & 46.25 & & \\
\hline $3 \mathrm{H}-5,45-46$ & 22.65 & 50.74 & 39.78 & 9.48 \\
\hline $3 \mathrm{H}-5,50-52$ & 22.71 & 60.25 & & \\
\hline $3 \mathrm{H}-5,60-62$ & 22.81 & 37.58 & & \\
\hline $3 \mathrm{H}-5,75-76$ & 22.95 & 69.14 & 19.42 & 11.43 \\
\hline $3 \mathrm{H}-5,90-92$ & 23.11 & 66.08 & & \\
\hline $3 \mathrm{H}-5,94-96$ & 23.14 & 68.42 & & \\
\hline $3 \mathrm{H}-5,105-106$ & 23.25 & 53.25 & 33.28 & 13.46 \\
\hline $3 \mathrm{H}-5,130-132$ & 23.51 & 68.42 & & \\
\hline $3 \mathrm{H}-5,135-136$ & 23.55 & 35.01 & 45.76 & 19.22 \\
\hline $3 \mathrm{H}-5,140-142$ & 23.61 & 15.42 & & \\
\hline $3 \mathrm{H}-6,10-12$ & 23.81 & 65.50 & & \\
\hline $3 \mathrm{H}-6,15-16$ & 23.85 & 58.10 & 24.33 & 17.56 \\
\hline $3 \mathrm{H}-6,20-22$ & 23.90 & 48.50 & & \\
\hline $3 \mathrm{H}-6,45-46$ & 24.15 & 29.57 & 50.44 & 19.98 \\
\hline $3 \mathrm{H}-6,50-52$ & 24.21 & 54.17 & & \\
\hline $3 \mathrm{H}-6,60-62$ & 24.31 & 62.67 & & \\
\hline $3 \mathrm{H}-6,75-76$ & 24.45 & 54.99 & 26.20 & 18.80 \\
\hline $3 \mathrm{H}-6,90-92$ & 24.61 & 37.50 & & \\
\hline $3 \mathrm{H}-6,94-96$ & 24.64 & 39.33 & & \\
\hline $3 \mathrm{H}-6,105-106$ & 24.75 & 54.09 & 31.28 & 14.62 \\
\hline $3 \mathrm{H}-6,130-132$ & 25.01 & 54.50 & & \\
\hline $3 \mathrm{H}-6,135-136$ & 25.05 & 63.22 & 24.92 & 11.85 \\
\hline
\end{tabular}


APPENDIX (continued).

\begin{tabular}{|c|c|c|c|c|}
\hline $\begin{array}{l}\text { Core, section, } \\
\text { interval }(\mathrm{cm})\end{array}$ & $\begin{array}{l}\text { Depth } \\
\text { (mbsf) }\end{array}$ & $\begin{array}{c}\mathrm{CaCO}_{3} \\
(\%)\end{array}$ & $\begin{array}{l}\text { Opal } \\
(\%)\end{array}$ & $\begin{array}{l}\text { Other } \\
(\%)\end{array}$ \\
\hline $3 \mathrm{H}-6,140-142$ & 25.11 & 57.58 & & \\
\hline $3 \mathrm{H}-7,10-12$ & 25.31 & 55.92 & & \\
\hline $3 \mathrm{H}-7,15-16$ & 25.34 & 69.46 & 17.03 & 13.51 \\
\hline $3 \mathrm{H}-7,20-22$ & 25.40 & 28.42 & & \\
\hline $3 \mathrm{H}-7,45-46$ & 25.65 & 49.78 & 37.17 & 13.04 \\
\hline $3 \mathrm{H}-7,50-52$ & 25.71 & 45.58 & & \\
\hline $3 \mathrm{H}-7,60-62$ & 25.81 & 63.75 & & \\
\hline $3 \mathrm{H}-7,75-76$ & 25.95 & 47.54 & 40.00 & 12.45 \\
\hline $4 \mathrm{H}-1,27-28$ & 25.97 & 60.24 & 25.69 & 14.07 \\
\hline $4 \mathrm{H}-1,30-32$ & 26.00 & 43.75 & & \\
\hline $4 \mathrm{H}-1,47-48$ & 26.17 & 48.63 & 33.44 & 17.92 \\
\hline $4 \mathrm{H}-1,70-72$ & 26.41 & 59.83 & & \\
\hline $4 \mathrm{H}-1,96-100$ & 26.66 & 62.25 & 24.05 & 13.69 \\
\hline $4 \mathrm{H}-1,100-102$ & 26.71 & 66.17 & & \\
\hline $4 \mathrm{H}-1,105-107$ & 26.76 & 55.67 & & \\
\hline $4 \mathrm{H}-1,109-110$ & 26.79 & 66.33 & 20.75 & 12.91 \\
\hline $4 \mathrm{H}-1,120-122$ & 26.91 & 37.66 & & \\
\hline $4 \mathrm{H}-1,127-128$ & 26.97 & 32.43 & 51.42 & 16.14 \\
\hline $4 \mathrm{H}-1,132-136$ & 27.02 & 43.50 & & \\
\hline $4 \mathrm{H}-1,140-142$ & 27.11 & 45.08 & & \\
\hline $4 \mathrm{H}-1,145-147$ & 27.15 & 58.17 & & \\
\hline $4 \mathrm{H}-2,16-17$ & 27.36 & 56.65 & 25.55 & 17.79 \\
\hline $4 \mathrm{H}-2,30-32$ & 27.50 & 74.75 & & \\
\hline $4 \mathrm{H}-2,47-48$ & 27.67 & 34.24 & 51.50 & 14.25 \\
\hline $4 \mathrm{H}-2,50-52$ & 27.71 & 35.00 & & \\
\hline $4 \mathrm{H}-2,70-72$ & 27.91 & 61.42 & & \\
\hline $4 \mathrm{H}-2,75-77$ & 27.96 & 37.92 & & \\
\hline $4 \mathrm{H}-2,78-79$ & 27.98 & 52.17 & 29.48 & 18.34 \\
\hline $4 \mathrm{H}-2,96-100$ & 28.16 & 34.50 & 48.11 & 17.38 \\
\hline $4 \mathrm{H}-2,100-102$ & 28.21 & 35.67 & & \\
\hline $4 \mathrm{H}-2,105-107$ & 28.26 & 36.46 & & \\
\hline $4 \mathrm{H}-2,108-109$ & 28.28 & 52.87 & 33.04 & 14.08 \\
\hline $4 \mathrm{H}-2,110-112$ & 28.30 & 30.69 & & \\
\hline $4 \mathrm{H}-2,120-122$ & 28.41 & 30.00 & & \\
\hline $4 \mathrm{H}-2,129-130$ & 28.49 & 43.43 & 43.31 & 13.25 \\
\hline $4 \mathrm{H}-2,132-136$ & 28.52 & 41.42 & & \\
\hline $4 \mathrm{H}-2,145-147$ & 28.65 & 42.83 & & \\
\hline $4 \mathrm{H}-3,10-12$ & 28.81 & 44.50 & & \\
\hline $4 \mathrm{H}-3,15-16$ & 28.85 & 54.58 & 29.77 & 15.64 \\
\hline $4 \mathrm{H}-3,30-32$ & 29.00 & 73.75 & & \\
\hline $4 \mathrm{H}-3,46-47$ & 29.16 & 78.57 & 9.28 & 12.14 \\
\hline $4 \mathrm{H}-3,50-52$ & 29.21 & 53.33 & & \\
\hline $4 \mathrm{H}-3,70-72$ & 29.41 & 47.67 & & \\
\hline $4 \mathrm{H}-3,75-76$ & 29.45 & 63.25 & 22.78 & 13.96 \\
\hline $4 \mathrm{H}-3,90-92$ & 29.61 & 39.83 & & \\
\hline $4 \mathrm{H}-3,96-100$ & 29.66 & 45.76 & 34.42 & 19.81 \\
\hline $4 \mathrm{H}-3,105-107$ & 29.76 & 44.17 & & \\
\hline $4 \mathrm{H}-3,120-122$ & 29.91 & 58.83 & & \\
\hline $4 \mathrm{H}-3,130-132$ & 30.01 & 68.83 & & \\
\hline $4 \mathrm{H}-3,132-136$ & 30.02 & 36.46 & & \\
\hline $4 \mathrm{H}-3,138-139$ & 30.08 & 62.90 & 26.24 & 10.85 \\
\hline $4 \mathrm{H}-3,145-147$ & 30.15 & 56.20 & & \\
\hline $4 \mathrm{H}-4,6-7$ & 30.26 & 53.14 & 27.53 & 19.32 \\
\hline $4 \mathrm{H}-4,10-12$ & 30.31 & 48.42 & & \\
\hline $4 \mathrm{H}-4,26-27$ & 30.46 & 72.03 & 13.45 & 14.51 \\
\hline $4 \mathrm{H}-4,30-32$ & 30.50 & 73.20 & & \\
\hline $4 \mathrm{H}-4,50-52$ & 30.71 & 73.17 & & \\
\hline $4 \mathrm{H}-4,67-68$ & 30.87 & 75.39 & 11.27 & 13.33 \\
\hline $4 \mathrm{H}-4,70-72$ & 30.91 & 71.83 & & \\
\hline $4 \mathrm{H}-4,90-92$ & 31.11 & 71.42 & & \\
\hline $4 \mathrm{H}-4,96-100$ & 31.16 & 76.04 & 10.64 & 13.31 \\
\hline $4 \mathrm{H}-4,105-107$ & 31.26 & 72.17 & & \\
\hline $4 \mathrm{H}-4,110-112$ & 31.30 & 63.72 & & \\
\hline $4 \mathrm{H}-4,120-122$ & 31.41 & 74.25 & & \\
\hline $4 \mathrm{H}-4,127-128$ & 31.47 & 76.64 & 11.72 & 11.64 \\
\hline $4 \mathrm{H}-4,130-132$ & 31.52 & 71.70 & & \\
\hline $4 \mathrm{H}-4,145-147$ & 31.65 & 75.60 & & \\
\hline $4 \mathrm{H}-5,10-12$ & 31.74 & 79.75 & & \\
\hline $4 \mathrm{H}-5,27-28$ & 31.97 & 49.42 & 23.85 & 26.72 \\
\hline $4 \mathrm{H}-5,30-32$ & 32.00 & 31.10 & & \\
\hline $4 H-5,38-42$ & 32.10 & 77.54 & & \\
\hline $4 \mathrm{H}-5,46-47$ & 32.16 & 25.98 & 47.24 & 26.77 \\
\hline $4 \mathrm{H}-5,50-52$ & 32.21 & 23.25 & & \\
\hline $4 \mathrm{H}-5,70-72$ & 32.41 & 61.50 & & \\
\hline $4 \mathrm{H}-5,75-76$ & 32.45 & 57.08 & 24.77 & 18.14 \\
\hline $4 \mathrm{H}-5,90-92$ & 32.61 & 68.83 & & \\
\hline $4 \mathrm{H}-5,96-100$ & 32.66 & 65.66 & 16.82 & 17.51 \\
\hline
\end{tabular}

APPENDIX (continued).

\begin{tabular}{|c|c|c|c|c|}
\hline $\begin{array}{l}\text { Core, section, } \\
\text { interval }(\mathrm{cm})\end{array}$ & $\begin{array}{l}\text { Depth } \\
\text { (mbsf) }\end{array}$ & $\begin{array}{c}\mathrm{CaCO}_{3} \\
(\%)\end{array}$ & $\begin{array}{c}\text { Opal } \\
(\%)\end{array}$ & $\begin{array}{l}\text { Other } \\
(\%)\end{array}$ \\
\hline $4 \mathrm{H}-5,105-107$ & 32.76 & 43.83 & & \\
\hline $4 \mathrm{H}-5,120-122$ & 32.91 & 49.67 & & \\
\hline $4 \mathrm{H}-5,127-128$ & 32.97 & 55.01 & 27.49 & 17.49 \\
\hline $4 \mathrm{H}-5,130-132$ & 33.01 & 54.08 & & \\
\hline $4 \mathrm{H}-5,132-136$ & 33.02 & 58.67 & & \\
\hline $4 \mathrm{H}-5,145-147$ & 33.15 & 35.30 & & \\
\hline $4 \mathrm{H}-6,10-12$ & 33.31 & 31.08 & & \\
\hline $4 \mathrm{H}-6,15-16$ & 33.35 & 35.99 & 35.40 & 28.60 \\
\hline $4 \mathrm{H}-6,30-32$ & 33.50 & 63.80 & & \\
\hline $4 \mathrm{H}-6,46-47$ & 33.66 & 39.50 & 36.35 & 24.14 \\
\hline $4 \mathrm{H}-6,50-52$ & 33.71 & 44.92 & & \\
\hline $4 \mathrm{H}-6,70-72$ & 33.91 & 50.67 & & \\
\hline $4 \mathrm{H}-6,75-76$ & 33.95 & 57.88 & 21.30 & 20.81 \\
\hline $4 \mathrm{H}-6,90-92$ & 34.11 & 65.33 & & \\
\hline $4 \mathrm{H}-6,96-100$ & 34.16 & 67.02 & 17.70 & 15.27 \\
\hline $4 \mathrm{H}-6,105-107$ & 34.26 & 71.67 & & \\
\hline $5 \mathrm{H}-1,13-14$ & 35.33 & 74.11 & 11.73 & 14.15 \\
\hline $5 \mathrm{H}-1,15-17$ & 35.35 & 68.90 & & \\
\hline $5 \mathrm{H}-1,20-22$ & 35.41 & 75.83 & & \\
\hline $5 \mathrm{H}-1,30-32$ & 35.41 & 7.17 & & \\
\hline $5 \mathrm{H}-1,35-39$ & 35.55 & 26.47 & 34.57 & 38.95 \\
\hline $5 \mathrm{H}-1,51-52$ & 35.72 & 69.50 & & \\
\hline $5 \mathrm{H}-1,70-72$ & 35.91 & 74.67 & & \\
\hline $5 \mathrm{H}-1,73-75$ & 35.95 & 70.00 & & \\
\hline $5 \mathrm{H}-1,78-79$ & 35.98 & 66.69 & 8.19 & 25.12 \\
\hline $5 \mathrm{H}-1,93-95$ & 36.13 & 49.70 & & \\
\hline $5 \mathrm{H}-1,107-108$ & 36.27 & 66.03 & 16.63 & 17.33 \\
\hline $5 \mathrm{H}-1,110-112$ & 36.31 & 55.83 & & \\
\hline $5 \mathrm{H}-1,120-122$ & 36.40 & 64.80 & & \\
\hline $5 \mathrm{H}-1,125-127$ & 36.46 & 60.42 & & \\
\hline $5 \mathrm{H}-1,135-136$ & 36.55 & 41.26 & 36.64 & 22.09 \\
\hline $5 \mathrm{H}-1,140-142$ & 36.61 & 36.75 & & \\
\hline $5 \mathrm{H}-2,15-17$ & 36.85 & 34.20 & & \\
\hline $5 \mathrm{H}-2,17-18$ & 36.87 & 55.36 & 23.81 & 20.82 \\
\hline $5 \mathrm{H}-2,30-32$ & 37.01 & 64.17 & & \\
\hline $5 \mathrm{H}-2,45-46$ & 37.15 & 53.18 & 27.22 & 19.59 \\
\hline $5 \mathrm{H}-2,51-52$ & 37.21 & 66.50 & & \\
\hline $5 \mathrm{H}-2,70-72$ & 37.41 & 57.08 & & \\
\hline $5 \mathrm{H}-2,75-76$ & 37.45 & 60.20 & 19.86 & 19.93 \\
\hline $5 \mathrm{H}-2,93-95$ & 37.63 & 72.90 & & \\
\hline $5 \mathrm{H}-2,105-106$ & 37.75 & 55.96 & 23.27 & 20.76 \\
\hline $5 \mathrm{H}-2,110-112$ & 37.81 & $57.00^{\circ}$ & & \\
\hline $5 \mathrm{H}-2,125-127$ & 37.96 & 35.50 & & \\
\hline $5 \mathrm{H}-2,135-136$ & 38.05 & 49.45 & 27.02 & 23.53 \\
\hline $5 \mathrm{H}-2,145-147$ & 38.16 & 66.08 & & \\
\hline $5 \mathrm{H}-3,15-17$ & 38.35 & 74.40 & & \\
\hline $5 \mathrm{H}-3,17-18$ & 38.37 & 71.91 & 13.16 & 14.92 \\
\hline $5 \mathrm{H}-3,30-32$ & 38.51 & 68.08 & & \\
\hline $5 \mathrm{H}-3,45-46$ & 38.65 & 29.74 & 25.08 & 45.17 \\
\hline $5 \mathrm{H}-3,51-52$ & 38.71 & 59.17 & & \\
\hline $5 \mathrm{H}-3,70-72$ & 38.91 & 33.08 & & \\
\hline $5 \mathrm{H}-3,76-77$ & 38.96 & 17.18 & 27.46 & 55.35 \\
\hline $5 \mathrm{H}-3,93-95$ & 39.13 & 18.30 & & \\
\hline $5 \mathrm{H}-3,105-106$ & 39.25 & 18.00 & 43.26 & 38.73 \\
\hline $5 \mathrm{H}-3,110-112$ & 39.31 & 23.50 & & \\
\hline $5 \mathrm{H}-3,125-127$ & 39.46 & 52.75 & & \\
\hline $5 \mathrm{H}-3,135-136$ & 39.55 & 43.55 & 28.53 & 27.91 \\
\hline $5 \mathrm{H}-3,145-147$ & 39.66 & 55.08 & & \\
\hline $5 \mathrm{H}-4,15-17$ & 39.85 & 53.20 & & \\
\hline $5 \mathrm{H}-4,17-18$ & 39.87 & 44.73 & 22.40 & 32.86 \\
\hline $5 \mathrm{H}-4,30-32$ & 40.01 & 52.17 & & \\
\hline $5 \mathrm{H}-4,45-46$ & 40.15 & 61.20 & 13.39 & 25.40 \\
\hline $5 \mathrm{H}-4,51-52$ & 40.21 & 75.08 & & \\
\hline $5 \mathrm{H}-4,70-72$ & 40.41 & 59.67 & & \\
\hline $5 \mathrm{H}-4,77-78$ & 40.47 & 71.87 & 12.85 & 15.27 \\
\hline $5 \mathrm{H}-4,93-95$ & 40.63 & 53.90 & & \\
\hline $5 \mathrm{H}-4,105-106$ & 40.75 & 62.38 & 22.17 & 15.44 \\
\hline $5 \mathrm{H}-4,110-112$ & 40.81 & 66.75 & & \\
\hline $5 \mathrm{H}-4,125-127$ & 40.96 & 71.50 & & \\
\hline $5 \mathrm{H}-4,135-136$ & 41.05 & 71.72 & 14.72 & 13.55 \\
\hline $5 \mathrm{H}-4,145-147$ & 41.16 & 74.33 & & \\
\hline $5 \mathrm{H}-5,15-17$ & 41.35 & 69.20 & & \\
\hline $5 \mathrm{H}-5,16-17$ & 41.36 & 68.62 & 15.98 & 15.39 \\
\hline $5 \mathrm{H}-5,30-32$ & 41.51 & 60.50 & & \\
\hline $5 \mathrm{H}-5,45-46$ & 41.65 & 53.17 & 22.41 & 24.41 \\
\hline $5 H-5,51-52$ & 41.71 & 66.83 & & \\
\hline $5 \mathrm{H}-5,70-72$ & 41.91 & 68.67 & & \\
\hline
\end{tabular}


APPENDIX (continued).

\begin{tabular}{|c|c|c|c|c|}
\hline $\begin{array}{l}\text { Core, section, } \\
\text { interval }(\mathrm{cm})\end{array}$ & $\begin{array}{l}\text { Depth } \\
\text { (mbsf) }\end{array}$ & $\begin{array}{c}\mathrm{CaCO}_{3} \\
(\%)\end{array}$ & $\begin{array}{c}\text { Opal } \\
(\%)\end{array}$ & $\begin{array}{l}\text { Other } \\
(\%)\end{array}$ \\
\hline $5 \mathrm{H}-5,76-77$ & 41.96 & 77.95 & 9.50 & 12.54 \\
\hline $5 \mathrm{H}-5,93-95$ & 42.13 & 64.80 & & \\
\hline $5 \mathrm{H}-5,105-106$ & 42.25 & 75.45 & 12.29 & 12.25 \\
\hline $5 \mathrm{H}-5,110-112$ & 42.31 & 66.75 & & \\
\hline $5 \mathrm{H}-5,125-127$ & 42.46 & 70.67 & & \\
\hline $5 \mathrm{H}-5,135-136$ & 42.55 & 54.79 & 21.55 & 23.65 \\
\hline $5 \mathrm{H}-5,145-147$ & 42.66 & 43.33 & & \\
\hline $5 \mathrm{H}-6,15-17$ & 42.85 & 34.30 & & \\
\hline $5 \mathrm{H}-6,17-18$ & 42.87 & 35.21 & 33.64 & 31.14 \\
\hline $5 \mathrm{H}-6,30-32$ & 43.01 & 26.33 & & \\
\hline $5 \mathrm{H}-6,45-46$ & 43.15 & 27.91 & 41.62 & 30.46 \\
\hline $5 \mathrm{H}-6,51-52$ & 43.21 & 21.00 & & \\
\hline $5 \mathrm{H}-6,70-72$ & 43.41 & 17.67 & & \\
\hline $5 \mathrm{H}-6,79-80$ & 43.49 & 23.47 & 32.90 & 43.62 \\
\hline $5 \mathrm{H}-6,93-95$ & 43.63 & 27.00 & & \\
\hline $5 \mathrm{H}-6,105-106$ & 43.75 & 31.20 & 31.27 & 37.52 \\
\hline $5 \mathrm{H}-6,110-112$ & 43.81 & 26.08 & & \\
\hline $5 \mathrm{H}-6,125-127$ & 43.96 & 50.67 & & \\
\hline $5 H-6,135-136$ & 44.05 & 54.92 & 19.67 & 25.40 \\
\hline $5 \mathrm{H}-6,145-147$ & 44.16 & 41.75 & & \\
\hline $5 \mathrm{H}-7,10-11$ & 44.30 & 62.45 & 17.46 & 20.08 \\
\hline $5 \mathrm{H}-7,15-17$ & 44.35 & 61.60 & & \\
\hline $5 \mathrm{H}-7,20-22$ & 44.41 & 22.08 & & \\
\hline $5 \mathrm{H}-7,30-32$ & 44.51 & 70.50 & & \\
\hline $5 \mathrm{H}-7,34-35$ & 44.54 & 72.13 & 13.06 & 14.80 \\
\hline $6 \mathrm{H}-2,60-62$ & 46.81 & 32.42 & & \\
\hline $6 \mathrm{H}-2,90-92$ & 47.11 & 31.50 & & \\
\hline $6 \mathrm{H}-2,100-102$ & 47.20 & 45.45 & & \\
\hline $6 \mathrm{H}-2,130-132$ & 47.51 & 27.17 & & \\
\hline $6 \mathrm{H}-3,10-12$ & 47.81 & 28.33 & & \\
\hline $6 \mathrm{H}-3,50-52$ & 48.21 & 43.25 & & \\
\hline $6 \mathrm{H}-3,90-92$ & 48.61 & 25.50 & & \\
\hline $6 \mathrm{H}-3,130-132$ & 49.01 & 55.12 & & \\
\hline $6 \mathrm{H}-4,10-12$ & 49.31 & 48.92 & & \\
\hline $6 \mathrm{H}-4,50-52$ & 49.71 & 34.67 & & \\
\hline $6 \mathrm{H}-4,90-92$ & 50.11 & 43.50 & & \\
\hline $6 \mathrm{H}-4,130-132$ & 50.51 & 54.83 & & \\
\hline $6 \mathrm{H}-5,10-12$ & 50.81 & 46.17 & & \\
\hline $6 \mathrm{H}-5,50-52$ & 51.21 & 30.17 & & \\
\hline $6 \mathrm{H}-5,90-92$ & 51.61 & 20.17 & & \\
\hline $6 \mathrm{H}-5,100-102$ & 51.70 & 16.60 & & \\
\hline $6 \mathrm{H}-5,130-132$ & 52.01 & 23.92 & & \\
\hline $6 \mathrm{H}-6,10-12$ & 52.31 & 12.83 & & \\
\hline $6 \mathrm{H}-6,50-52$ & 52.71 & 23.33 & & \\
\hline $6 \mathrm{H}-6,90-92$ & 53.11 & 32.67 & & \\
\hline $6 \mathrm{H}-6,130-132$ & 53.51 & 62.58 & & \\
\hline $6 \mathrm{H}-7,10-12$ & 53.81 & 59.00 & & \\
\hline $6 \mathrm{H}-7,50-52$ & 54.21 & 51.17 & & \\
\hline $6 \mathrm{H}-7,85-87$ & 54.56 & 72.75 & & \\
\hline $7 \mathrm{H}-1,80-82$ & 55.01 & 53.17 & & \\
\hline $7 \mathrm{H}-1,135-137$ & 55.56 & 43.50 & & \\
\hline $7 \mathrm{H}-2,70-72$ & 56.41 & 39.75 & & \\
\hline $7 \mathrm{H}-2,110-112$ & 56.81 & 42.58 & & \\
\hline $7 \mathrm{H}-2,140-142$ & 57.11 & 52.08 & & \\
\hline $7 \mathrm{H}-3,10-12$ & 57.31 & 42.67 & & \\
\hline $7 \mathrm{H}-3,50-52$ & 57.71 & 37.83 & & \\
\hline $7 \mathrm{H}-3,90-92$ & 58.11 & 28.08 & & \\
\hline $7 \mathrm{H}-3,100-102$ & 58.20 & 20.93 & & \\
\hline $7 \mathrm{H}-3,130-132$ & 58.51 & 21.42 & & \\
\hline $7 \mathrm{H}-4,10-12$ & 58.81 & 11.08 & & \\
\hline $7 \mathrm{H}-4,50-52$ & 59.21 & 17.75 & & \\
\hline $7 \mathrm{H}-4,90-92$ & 59.61 & 17.92 & & \\
\hline $7 \mathrm{H}-4,130-132$ & 60.01 & 28.17 & & \\
\hline $7 \mathrm{H}-5,10-12$ & 60.31 & 55.50 & & \\
\hline $7 \mathrm{H}-5,50-52$ & 60.71 & 48.92 & & \\
\hline $7 \mathrm{H}-5,90-92$ & 61.11 & 46.83 & & \\
\hline $7 \mathrm{H}-5,100-102$ & 61.20 & 58.96 & & \\
\hline $7 \mathrm{H}-5,130-132$ & 61.51 & 39.92 & & \\
\hline $7 \mathrm{H}-6,10-12$ & 61.81 & 40.00 & & \\
\hline $7 \mathrm{H}-6,50-52$ & 62.21 & 45.83 & & \\
\hline $7 \mathrm{H}-6,90-92$ & 62.61 & 76.25 & & \\
\hline $7 \mathrm{H}-6,130-132$ & 63.01 & 38.75 & & \\
\hline $7 \mathrm{H}-7,10-12$ & 63.31 & 25.47 & & \\
\hline $7 \mathrm{H}-7,50-52$ & 63.71 & 17.83 & & \\
\hline $8 \mathrm{H}-1,10-12$ & 63.81 & 53.17 & & \\
\hline $8 \mathrm{H}-1,50-52$ & 64.21 & 69.92 & & \\
\hline $8 \mathrm{H}-1,90-92$ & 64.61 & 48.25 & & \\
\hline
\end{tabular}

APPENDIX (continued).

\begin{tabular}{|c|c|c|c|c|}
\hline $\begin{array}{l}\text { Core, section, } \\
\text { interval }(\mathrm{cm})\end{array}$ & $\begin{array}{l}\text { Depth } \\
\text { (mbsf) }\end{array}$ & $\begin{array}{c}\mathrm{CaCO}_{3} \\
(\%)\end{array}$ & $\begin{array}{l}\text { Opal } \\
(\%)\end{array}$ & $\begin{array}{l}\text { Other } \\
(\%)\end{array}$ \\
\hline $8 \mathrm{H}-2,50-52$ & 65.71 & 9.08 & & \\
\hline $8 \mathrm{H}-2,75-77$ & 65.96 & 8.75 & & \\
\hline $8 \mathrm{H}-2,130-132$ & 66.51 & 23.42 & & \\
\hline $8 \mathrm{H}-3,10-12$ & 66.81 & 11.92 & & \\
\hline $8 \mathrm{H}-3,30-32$ & 67.01 & 54.04 & & \\
\hline $8 \mathrm{H}-3,50-52$ & 67.21 & 58.08 & & \\
\hline $8 \mathrm{H}-3,75-77$ & 67.46 & 6.66 & & \\
\hline $8 \mathrm{H}-3,110-112$ & 67.81 & 21.10 & & \\
\hline $8 \mathrm{H}-3,130-132$ & 68.01 & 25.17 & & \\
\hline $8 \mathrm{H}-4,10-12$ & 68.31 & 42.00 & & \\
\hline $8 \mathrm{H}-4,50-52$ & 68.71 & 15.25 & & \\
\hline $9 \mathrm{H}-1,10-12$ & 73.31 & 17.25 & & \\
\hline $9 \mathrm{H}-1,50-52$ & 73.71 & 19.00 & & \\
\hline $9 \mathrm{H}-1,90-92$ & 74.11 & 20.42 & & \\
\hline $9 \mathrm{H}-1,110-112$ & 74.30 & 24.52 & & \\
\hline $9 \mathrm{H}-1,130-132$ & 74.51 & 24.58 & & \\
\hline $9 \mathrm{H}-2,10-12$ & 74.81 & 22.67 & & \\
\hline $9 \mathrm{H}-2,50-52$ & 75.21 & 26.25 & & \\
\hline $9 \mathrm{H}-2,130-132$ & 76.01 & 34.00 & & \\
\hline $9 \mathrm{H}-3,10-12$ & 76.31 & 36.17 & & \\
\hline $9 \mathrm{H}-3,50-52$ & 76.71 & 46.17 & & \\
\hline $9 \mathrm{H}-3,90-92$ & 77.11 & 40.92 & & \\
\hline $9 \mathrm{H}-3,130-132$ & 77.51 & 46.17 & & \\
\hline $9 \mathrm{H}-4,10-12$ & 77.81 & 55.83 & & \\
\hline $9 \mathrm{H}-4,50-52$ & 78.21 & 44.58 & & \\
\hline $9 \mathrm{H}-4,90-92$ & 78.61 & 65.67 & & \\
\hline $9 \mathrm{H}-4,130-132$ & 79.01 & 28.75 & & \\
\hline $9 \mathrm{H}-5,10-12$ & 79.31 & 27.33 & & \\
\hline $9 \mathrm{H}-5,50-52$ & 79.71 & 34.33 & & \\
\hline $9 \mathrm{H}-5,90-92$ & 80.11 & 43.75 & & \\
\hline $9 \mathrm{H}-5,110-112$ & 80.30 & 50.87 & & \\
\hline $9 \mathrm{H}-5,130-132$ & 80.51 & 55.00 & & \\
\hline $9 \mathrm{H}-6,10-12$ & 80.81 & 31.50 & & \\
\hline $9 \mathrm{H}-6,50-52$ & 81.21 & 47.17 & & \\
\hline $9 \mathrm{H}-6,90-92$ & 81.61 & 66.17 & & \\
\hline $9 \mathrm{H}-6,130-132$ & 82.01 & 63.00 & & \\
\hline $9 \mathrm{H}-7,10-12$ & 82.31 & 61.00 & & \\
\hline $9 \mathrm{H}-7,50-52$ & 82.71 & 37.92 & & \\
\hline $10 \mathrm{H}-1,10-12$ & 82.81 & 13.21 & & \\
\hline $10 \mathrm{H}-1,50-52$ & 83.21 & 15.83 & & \\
\hline $10 \mathrm{H}-1,90-92$ & 83.61 & 12.42 & & \\
\hline $10 \mathrm{H}-1,130-132$ & 84.01 & 11.00 & & \\
\hline $10 \mathrm{H}-2,10-12$ & 84.31 & 10.75 & & \\
\hline $10 \mathrm{H}-2,50-52$ & 84.71 & 11.58 & & \\
\hline $10 \mathrm{H}-2,90-92$ & 85.11 & 11.25 & & \\
\hline $10 \mathrm{H}-2,110-112$ & 85.30 & 13.51 & & \\
\hline $10 \mathrm{H}-2,130-132$ & 85.51 & 11.33 & & \\
\hline $10 \mathrm{H}-3,10-12$ & 85.81 & 10.42 & & \\
\hline $10 \mathrm{H}-3,50-52$ & 86.21 & 11.50 & & \\
\hline $10 \mathrm{H}-3,90-92$ & 86.61 & 10.83 & & \\
\hline $10 \mathrm{H}-3,130-132$ & 87.01 & 8.42 & & \\
\hline $10 \mathrm{H}-4,10-12$ & 87.31 & 12.17 & & \\
\hline $10 \mathrm{H}-4,59-61$ & 87.80 & 10.17 & & \\
\hline $10 \mathrm{H}-4,90-92$ & 88.11 & 16.25 & & \\
\hline $10 \mathrm{H}-4,130-132$ & 88.51 & 55.25 & & \\
\hline $10 \mathrm{H}-5,10-12$ & 88.81 & 56.08 & & \\
\hline $10 \mathrm{H}-5,50-52$ & 89.21 & 58.75 & & \\
\hline $10 \mathrm{H}-5,90-92$ & 89.61 & 62.67 & & \\
\hline $10 \mathrm{H}-5,110-112$ & 89.80 & 61.38 & & \\
\hline $10 \mathrm{H}-5,130-132$ & 90.01 & 63.08 & & \\
\hline $10 \mathrm{H}-7,10-12$ & 91.81 & 62.33 & & \\
\hline $10 \mathrm{H}-7,50-52$ & 92.21 & 62.42 & & \\
\hline $11 \mathrm{H}-1,10-12$ & 92.31 & 7.42 & & \\
\hline $10 \mathrm{H}-7,90-92$ & 92.61 & 39.67 & & \\
\hline $10 \mathrm{H}-7,130-132$ & 93.01 & 21.83 & & \\
\hline $11 \mathrm{H}-1,90-92$ & 93.11 & 6.58 & & \\
\hline $11 \mathrm{H}-2,10-12$ & 93.81 & 7.50 & & \\
\hline $11 \mathrm{H}-2,90-92$ & 94.61 & 7.25 & & \\
\hline $11 \mathrm{H}-2,110-112$ & 94.80 & 8.01 & & \\
\hline $11 \mathrm{H}-3,10-12$ & 95.31 & 9.00 & & \\
\hline $11 \mathrm{H}-3,90-92$ & 96.11 & 8.58 & & \\
\hline $11 \mathrm{H}-4,10-12$ & 96.81 & 21.17 & & \\
\hline $11 \mathrm{H}-4,50-52$ & 97.21 & 25.33 & & \\
\hline $11 \mathrm{H}-4,90-92$ & 97.61 & 25.33 & & \\
\hline $11 \mathrm{H}-4,130-132$ & 98.01 & 29.67 & & \\
\hline $11 \mathrm{H}-6,50-52$ & 100.21 & 35.00 & & \\
\hline $11 \mathrm{H}-6,90-92$ & 100.61 & 19.25 & & \\
\hline
\end{tabular}


APPENDIX (continued).

\begin{tabular}{|c|c|c|c|c|}
\hline $\begin{array}{l}\text { Core, section, } \\
\text { interval }(\mathrm{cm})\end{array}$ & $\begin{array}{l}\text { Depth } \\
\text { (mbsf) }\end{array}$ & $\begin{array}{c}\mathrm{CaCO}_{3} \\
(\%)\end{array}$ & $\begin{array}{l}\text { Opal } \\
(\%)\end{array}$ & $\begin{array}{l}\text { Other } \\
(\%)\end{array}$ \\
\hline $11 \mathrm{H}-6,110-112$ & 100.80 & 13.93 & & \\
\hline $11 \mathrm{H}-7,10-12$ & 101.31 & 15.67 & & \\
\hline $11 \mathrm{H}-7,50-52$ & 101.71 & 12.75 & & \\
\hline $12 \mathrm{H}-1,10-12$ & 101.81 & 31.00 & & \\
\hline $12 \mathrm{H}-1,50-52$ & 102.21 & 33.25 & & \\
\hline $11 \mathrm{H}-7,130-132$ & 102.51 & 16.75 & & \\
\hline $12 \mathrm{H}-1,90-92$ & 102.61 & 45.00 & & \\
\hline $12 \mathrm{H}-1,130-132$ & 103.01 & 78.83 & & \\
\hline $12 \mathrm{H}-2,10-12$ & 103.31 & 31.58 & & \\
\hline $12 \mathrm{H}-2,50-52$ & 103.71 & 44.67 & & \\
\hline $12 \mathrm{H}-2,90-92$ & 104.11 & 49.75 & & \\
\hline $12 \mathrm{H}-2,110-112$ & 104.30 & 45.54 & & \\
\hline $12 \mathrm{H}-2,130-132$ & 104.51 & 52.17 & & \\
\hline $12 \mathrm{H}-3,10-12$ & 104.81 & 51.67 & & \\
\hline $12 \mathrm{H}-3,50-52$ & 105.21 & 77.75 & & \\
\hline $12 \mathrm{H}-3,90-92$ & 105.61 & 66.00 & & \\
\hline $12 \mathrm{H}-3,130-132$ & 106.01 & 74.58 & & \\
\hline $12 \mathrm{H}-4,10-12$ & 106.31 & 71.58 & & \\
\hline $12 \mathrm{H}-4,50-52$ & 106.71 & 73.92 & & \\
\hline $12 \mathrm{H}-4,90-92$ & 107.11 & 62.33 & & \\
\hline $12 \mathrm{H}-4,130-132$ & 107.51 & 35.33 & & \\
\hline $12 \mathrm{H}-5,10-12$ & 107.81 & 63.75 & & \\
\hline $12 \mathrm{H}-5,50-52$ & 108.21 & 50.75 & & \\
\hline $12 \mathrm{H}-5,90-92$ & 108.61 & 70.83 & & \\
\hline $12 \mathrm{H}-5,110-112$ & 108.80 & 79.90 & & \\
\hline $12 \mathrm{H}-5,130-132$ & 109.01 & 55.00 & & \\
\hline $12 \mathrm{H}-6,10-12$ & 109.31 & 68.92 & & \\
\hline $12 \mathrm{H}-6,50-52$ & 109.71 & 73.42 & & \\
\hline $12 \mathrm{H}-6,90-92$ & 110.11 & 72.67 & & \\
\hline $12 \mathrm{H}-6,130-132$ & 110.51 & 61.75 & & \\
\hline $12 \mathrm{H}-7,10-12$ & 110.81 & 74.58 & & \\
\hline $13 \mathrm{H}-1,110-112$ & 112.30 & 19.52 & & \\
\hline $13 \mathrm{H}-4,110-112$ & 116.80 & 77.40 & & \\
\hline $14 \mathrm{H}-1,110-112$ & 121.80 & 63.72 & & \\
\hline $14 \mathrm{H}-4,110-112$ & 126.30 & 74.06 & & \\
\hline $15 \mathrm{H}-2,110-112$ & 131.94 & 73.98 & & \\
\hline $15 \mathrm{H}-5,110-112$ & 136.44 & 72.81 & & \\
\hline $17 X-2,100-102$ & 149.70 & 54.04 & & \\
\hline $17 X-4,100-102$ & 152.70 & 53.96 & & \\
\hline $18 \mathrm{X}-3,110-112$ & 160.80 & 52.63 & & \\
\hline $18 \mathrm{X}-6,110-112$ & 165.30 & 55.79 & & \\
\hline $19 \mathrm{X}-2,90-92$ & 168.60 & 53.63 & & \\
\hline $22 \mathrm{X}-1,100-102$ & 195.70 & 50.04 & & \\
\hline $23 X-1,15-16$ & 204.35 & 76.75 & 12.01 & 11.24 \\
\hline $23 \mathrm{X}-1,45-46$ & 204.65 & 56.22 & 21.70 & 22.08 \\
\hline $23 \mathrm{X}-1,75-76$ & 204.95 & 54.31 & 21.16 & 24.53 \\
\hline $23 \mathrm{X}-1,103-104$ & 205.23 & 52.21 & 19.44 & 28.35 \\
\hline $23 \mathrm{X}-1,134-135$ & 205.54 & 41.18 & 28.30 & 30.52 \\
\hline $23 X-2,15-16$ & 205.85 & 74.32 & 8.71 & 16.97 \\
\hline $23 \mathrm{X}-2,45-46$ & 206.15 & 75.54 & 8.26 & 16.20 \\
\hline $23 \times-2,75-76$ & 206.45 & 75.12 & 8.69 & 16.19 \\
\hline $23 X-2,100-102$ & 206.70 & 67.55 & & \\
\hline $23 X-2,105-106$ & 206.75 & 75.64 & 7.19 & 17.17 \\
\hline $23 X-2,135-136$ & 207.05 & 80.49 & 6.23 & 13.28 \\
\hline $23 \mathrm{X}-3,15-16$ & 207.35 & 57.52 & 6.42 & 36.06 \\
\hline $23 X-3,45-46$ & 207.65 & 81.43 & 6.55 & 12.02 \\
\hline $23 X-3,75-76$ & 207.95 & 84.57 & 5.84 & 9.59 \\
\hline $23 X-3,100-102$ & 208.20 & 79.90 & & \\
\hline $23 X-3,105-106$ & 208.25 & 81.58 & 6.83 & 11.59 \\
\hline $23 \mathrm{X}-3,135-136$ & 208.55 & 70.64 & 9.56 & 19.80 \\
\hline $23 X-4,15-16$ & 208.85 & 81.47 & 5.26 & 13.27 \\
\hline $23 \mathrm{X}-4,45-46$ & 209.15 & 84.36 & 5.50 & 10.14 \\
\hline $23 X-4,75-76$ & 209.45 & 82.86 & 4.87 & 12.27 \\
\hline $23 X-4,100-102$ & 209.70 & 73.39 & & \\
\hline $23 \mathrm{X}-4,105-106$ & 209.75 & 74.17 & 7.15 & 18.68 \\
\hline $23 X-4,135-136$ & 210.05 & 80.62 & 4.93 & 14.45 \\
\hline $23 X-5,15-16$ & 210.35 & 74.90 & 5.81 & 19.29 \\
\hline $23 X-5,47-48$ & 210.67 & 79.53 & 5.31 & 15.16 \\
\hline $23 X-5,75-76$ & 210.95 & 75.09 & 7.41 & 17.50 \\
\hline $23 \mathrm{X}-5,100-102$ & 211.20 & 77.73 & & \\
\hline $23 \mathrm{X}-5,105-106$ & 211.25 & 78.91 & 5.89 & 15.20 \\
\hline $23 X-5,135-136$ & 211.55 & 74.74 & 8.95 & 16.31 \\
\hline $24 \mathrm{X}-1,15-16$ & 213.85 & 66.76 & 16.69 & 16.55 \\
\hline $24 \mathrm{X}-1,20-22$ & 213.90 & 77.66 & & \\
\hline $24 \mathrm{X}-1,45-46$ & 214.15 & 77.80 & 10.55 & 11.65 \\
\hline $24 \mathrm{X}-1,50-52$ & 214.20 & 72.30 & & \\
\hline $24 \mathrm{X}-1,60-64$ & 214.30 & 86.06 & 6.58 & 7.36 \\
\hline
\end{tabular}

APPENDIX (continued).

\begin{tabular}{|c|c|c|c|c|}
\hline $\begin{array}{l}\text { Core, section, } \\
\text { interval }(\mathrm{cm})\end{array}$ & $\begin{array}{l}\text { Depth } \\
\text { (mbsf) }\end{array}$ & $\begin{array}{c}\mathrm{CaCO}_{3} \\
(\%)\end{array}$ & $\begin{array}{l}\text { Opal } \\
(\%)\end{array}$ & $\begin{array}{l}\text { Other } \\
(\%)\end{array}$ \\
\hline $24 X-1,76-77$ & 214.46 & 82.42 & 7.89 & 9.69 \\
\hline $24 \mathrm{X}-1,100-102$ & 214.70 & 71.56 & & \\
\hline $24 X-1,105-106$ & 214.75 & 80.91 & 8.94 & 10.15 \\
\hline $24 X-1,110-112$ & 214.80 & 81.66 & & \\
\hline $24 X-1,135-136$ & 215.05 & 83.75 & 5.98 & 10.27 \\
\hline $24 X-1,140-142$ & 215.10 & 76.40 & & \\
\hline $24 X-2,15-16$ & 215.35 & 84.88 & 5.70 & 9.42 \\
\hline $24 \mathrm{X}-2,20-22$ & 215.41 & 74.75 & & \\
\hline $24 X-2,45-46$ & 215. & 77.62 & 6.51 & 15.87 \\
\hline $24 X-2,50-52$ & 215.70 & 73.00 & & \\
\hline $24 X-2,60-64$ & 215.80 & 82.59 & 5.50 & 11.91 \\
\hline $24 \mathrm{X}-2,100-102$ & 216.20 & 78.31 & & \\
\hline $24 \mathrm{X}-2,105-106$ & 216.25 & 80.96 & 8.25 & 10.79 \\
\hline $24 X-2,114-116$ & 216.35 & 89.33 & & \\
\hline $24 X-2,135-136$ & 216.55 & 82.91 & 4.55 & 12.54 \\
\hline $24 X-2,140-142$ & 216.60 & 81.20 & & \\
\hline $24 X-3,15-16$ & 216.85 & 77.15 & 6.56 & 16.29 \\
\hline $24 X-3,20-22$ & 216.9 & 74. & & \\
\hline $24 X-3,45-46$ & 217.15 & 78.5 & 7.53 & 13.89 \\
\hline $24 \mathrm{X}-3,50-52$ & 217.20 & 77.80 & & \\
\hline $24 X-3,60-64$ & 217.30 & 75.80 & 8.25 & 15.95 \\
\hline $24 X-3,100-102$ & 217.70 & 67.47 & & \\
\hline $24 X-3,105-106$ & 217.75 & 67.78 & 10.79 & 21.43 \\
\hline $24 X-3,110-112$ & 217.81 & 69.00 & & \\
\hline $24 X-3,135-136$ & 218.05 & 79.55 & 5.43 & 15.02 \\
\hline $24 X-3,140-142$ & 218.10 & 80.50 & & \\
\hline $24 X-4,16-17$ & 218.36 & 79.02 & 7.31 & 13.67 \\
\hline $24 X-4,20-22$ & 218.41 & 80.50 & & \\
\hline $24 X-4,45-46$ & 218.65 & 75.14 & 7.71 & 17.15 \\
\hline $24 \mathrm{X}-4,50-52$ & 218.70 & 70.20 & & \\
\hline $24 X-4,60-64$ & 218.80 & 59.73 & 14.13 & 26.14 \\
\hline $24 \mathrm{X}-4,100-102$ & 219.20 & 47.54 & & \\
\hline $24 X-4,105-106$ & 219.25 & 43.17 & 22.76 & 34.07 \\
\hline $24 X-4,110-112$ & 219.31 & 40.58 & & \\
\hline $24 X-4,136-137$ & 219.56 & 62.45 & 15.93 & 21.62 \\
\hline $24 \mathrm{X}-4,140-142$ & 219.60 & 55.40 & & \\
\hline $24 X-5,16-17$ & 219.86 & 65.85 & 14.02 & 20.13 \\
\hline $24 X-5,20-22$ & 219.91 & 64.16 & & \\
\hline $24 X-5,45-46$ & 220.15 & 50.10 & 17.60 & 32.30 \\
\hline $24 X-5,50-52$ & 220.20 & 52.75 & & \\
\hline $24 X-5,60-64$ & 220.30 & 65.10 & 10.92 & 23.98 \\
\hline $24 \mathrm{X}-5,100-102$ & 220.70 & 68.05 & & \\
\hline $24 X-5,105-106$ & 220.75 & 67.62 & 8.95 & 23.43 \\
\hline $24 X-5,110-112$ & 220.81 & 61.58 & & \\
\hline $24 X-5,135-136$ & 221.05 & 57.01 & 9.50 & 33.49 \\
\hline $24 X-5,140-142$ & 221.10 & 67.00 & & \\
\hline $24 X-6,10-12$ & 221.30 & 56.42 & & \\
\hline $24 \mathrm{X}-6,13-14$ & 221.33 & 46.00 & 14.95 & 39.05 \\
\hline $24 X-6,40-42$ & 221.61 & 38.75 & & \\
\hline $24 X-6,45-46$ & 221.65 & 56.31 & 14.24 & 29.45 \\
\hline $24 X-6,88-92$ & 222.08 & 52.95 & 16.52 & 30.53 \\
\hline $24 \mathrm{X}-6,100-102$ & 222.20 & 16.35 & & \\
\hline $24 \mathrm{X}-6,105-106$ & 222.25 & 3.25 & 28.37 & 68.38 \\
\hline $24 X-6,110-112$ & 222.31 & 4.7 & & \\
\hline $24 X-6,135-136$ & 222.55 & 66.50 & 12.71 & 20.79 \\
\hline $24 X-6,140-142$ & 222.60 & 49.17 & & \\
\hline $24 X-7,15-16$ & 222.85 & 47.50 & 17.70 & 34.80 \\
\hline $24 X-7,40-42$ & 223.10 & 48.00 & & \\
\hline $24 X-7,45-46$ & 223.15 & 53.11 & 13.41 & 33.48 \\
\hline $24 X-7,50-52$ & 223.20 & 48.70 & & \\
\hline $25 \mathrm{X}-1,20-22$ & 223.41 & 79.25 & & \\
\hline $25 \mathrm{X}-1,28-32$ & 223.48 & 77.54 & 8.33 & 14.13 \\
\hline $25 \mathrm{X}-1,49-50$ & 223.69 & 74.16 & 8.85 & 16.99 \\
\hline $25 x-1,52-54$ & 223.72 & 72.2 & & \\
\hline $25 \times-1,75-76$ & 223.95 & 27.49 & 29.44 & 43.07 \\
\hline $25 \mathrm{X}-1,100-102$ & 224.20 & 31.36 & & \\
\hline $25 \mathrm{X}-1,105-106$ & 224.25 & 40.19 & 28.21 & 31.60 \\
\hline $25 \mathrm{X}-1,108-110$ & 224.29 & 43.75 & & \\
\hline $25 \mathrm{X}-1,135-136$ & 224.55 & 48.28 & 11.15 & 40.57 \\
\hline $25 \mathrm{X}-1,140-142$ & 224.60 & 70.42 & & \\
\hline $25 X-2,20-22$ & 224.91 & 47.50 & & \\
\hline $25 X-2,28-32$ & 224.98 & 39.74 & 24.99 & 35.27 \\
\hline $25 X-2,49-50$ & 225.19 & 15.27 & 35.42 & 49.31 \\
\hline $25 X-2,52-54$ & 225.22 & 18.40 & & \\
\hline $25 X-2,75-76$ & 225.45 & 65.45 & 15.25 & 19.30 \\
\hline $25 X-2,100-102$ & 225.70 & 63.72 & & \\
\hline $25 \mathrm{X}-2,105-106$ & 225.75 & 57.03 & 16.93 & 26.04 \\
\hline
\end{tabular}


APPENDIX (continued).

\begin{tabular}{|c|c|c|c|c|}
\hline $\begin{array}{l}\text { Core, section, } \\
\text { interval }(\mathrm{cm})\end{array}$ & $\begin{array}{l}\text { Depth } \\
\text { (mbsf) }\end{array}$ & $\begin{array}{c}\mathrm{CaCO}_{3} \\
(\%)\end{array}$ & $\begin{array}{l}\text { Opal } \\
(\%)\end{array}$ & $\begin{array}{l}\text { Other } \\
(\%)\end{array}$ \\
\hline $25 X-2,108-110$ & 225.79 & 55.50 & & \\
\hline $25 \mathrm{X}-2,135-136$ & 226.05 & 58.53 & 18.54 & 22.93 \\
\hline $25 \mathrm{X}-2,140-142$ & 226.10 & 62.90 & & \\
\hline $25 \mathrm{X}-3,20-22$ & 226.41 & 48.41 & & \\
\hline $25 X-3,28-32$ & 226.48 & 46.85 & 18.73 & 34.42 \\
\hline $25 X-3,48-49$ & 226.68 & 51.72 & 19.51 & 28.77 \\
\hline $25 \mathrm{X}-3,50-52$ & 226.70 & 49.46 & & \\
\hline $25 X-3,52-54$ & 226.72 & 60.92 & & \\
\hline $25 X-3,75-76$ & 226.95 & 86.12 & 6.30 & 7.58 \\
\hline $25 X-3,105-106$ & 227.25 & 87.72 & 4.69 & 7.59 \\
\hline $25 X-3,108-110$ & 227.29 & 86.91 & & \\
\hline $25 \mathrm{X}-3,135-136$ & 227.55 & 66.51 & 14.93 & 18.56 \\
\hline $25 \mathrm{X}-3,140-142$ & 227.60 & 66.00 & & \\
\hline $25 \mathrm{X}-4,20-22$ & 227.91 & 47.83 & & \\
\hline $25 \mathrm{X}-4,28-32$ & 227.98 & 6.80 & 34.33 & 58.87 \\
\hline $25 X-4,48-49$ & 228.18 & 4.09 & 40.88 & 55.03 \\
\hline $25 X-4,50-52$ & 228.20 & 8.01 & & \\
\hline $25 X-4,52-53$ & 228.22 & 8.58 & & \\
\hline $25 X-4,75-76$ & 228.45 & 61.07 & 17.48 & 21.45 \\
\hline $25 X-4,105-106$ & 228.75 & 54.33 & 22.52 & 23.15 \\
\hline $25 X-4,108-110$ & 228.79 & 54.33 & & \\
\hline $25 X-4,135-136$ & 229.05 & 46.92 & 24.70 & 28.38 \\
\hline $25 X-4,140-142$ & 229.10 & 49.00 & & \\
\hline $25 X-5,20-22$ & 229.41 & 69.71 & & \\
\hline $25 X-5,28-32$ & 229.48 & 77.14 & 7.32 & 15.54 \\
\hline $25 X-5,49-50$ & 229.69 & 85.14 & 4.90 & 9.96 \\
\hline $25 X-5,52-54$ & 229.72 & 84.20 & & \\
\hline $25 X-5,75-76$ & 229.95 & 76.56 & 10.60 & 12.84 \\
\hline $25 X-5,100-102$ & 230.20 & 58.80 & & \\
\hline $25 X-5,105-106$ & 230.25 & 55.88 & 17.97 & 26.15 \\
\hline $25 X-5,108-110$ & 230.29 & 57.00 & & \\
\hline $25 X-5,135-136$ & 230.55 & 45.44 & 22.00 & 32.56 \\
\hline $25 X-5,140-142$ & 230.60 & 42.70 & & \\
\hline $25 X-6,20-22$ & 230.91 & 76.16 & & \\
\hline $25 \mathrm{X}-6,28-32$ & 230.98 & 77.22 & 9.93 & 12.85 \\
\hline $25 \mathrm{X}-6,49-50$ & 231.19 & 53.95 & 28.78 & 17.27 \\
\hline $25 X-6,52-54$ & 231.22 & 60.30 & & \\
\hline $25 X-6,75-76$ & 231.45 & 50.36 & 21.77 & 27.87 \\
\hline $25 \mathrm{X}-6,100-102$ & 231.70 & 61.55 & & \\
\hline $25 X-6,105-106$ & 231.75 & 64.30 & 16.91 & 18.79 \\
\hline $25 X-6,108-110$ & 231.79 & 60.50 & & \\
\hline $25 X-6,135-136$ & 232.05 & 78.27 & 7.99 & 13.74 \\
\hline $25 X-6,140-142$ & 232.10 & 71.75 & & \\
\hline $25 X-7,13-14$ & 232.33 & 77.59 & 12.24 & 10.17 \\
\hline $25 X-7,20-22$ & 232.41 & 70.50 & & \\
\hline $25 \times-7,28-32$ & 232.48 & 59.47 & 16.87 & 23.66 \\
\hline $25 X-7,52-54$ & 232.72 & 47.60 & & \\
\hline $25 X-7,57-58$ & 232.77 & 38.26 & 31.73 & 30.01 \\
\hline $26 X-1,15-16$ & 232.85 & 54.12 & 23.30 & 22.58 \\
\hline $26 X-1,45-46$ & 233.15 & 73.90 & 10.49 & 15.61 \\
\hline $26 \mathrm{X}-1,50-52$ & 233.20 & 70.83 & & \\
\hline $26 X-1,75-76$ & 233.45 & 70.15 & 15.52 & 14.33 \\
\hline $26 \mathrm{X}-1,100-102$ & 233.70 & 60.21 & & \\
\hline $26 \mathrm{X}-1,105-106$ & 233.75 & 61.30 & 19.10 & 19.60 \\
\hline $26 \mathrm{X}-1,110-112$ & 233.81 & 56.08 & & \\
\hline $26 \mathrm{X}-1,135-136$ & 234.05 & 44.54 & 31.83 & 23.63 \\
\hline $26 \mathrm{X}-1,140-142$ & 234.10 & 44.08 & & \\
\hline $26 X-2,15-16$ & 234.35 & 43.38 & 30.12 & 26.50 \\
\hline $26 \mathrm{X}-2,20-22$ & 234.41 & 44.75 & & \\
\hline $26 \mathrm{X}-2,42-43$ & 234.62 & 73.58 & 11.04 & 15.38 \\
\hline $26 \mathrm{X}-2,50-52$ & 234.70 & 76.90 & & \\
\hline $26 X-2,75-76$ & 234.95 & 80.21 & 10.12 & 9.67 \\
\hline $26 X-2,100-102$ & 235.20 & 50.12 & & \\
\hline $26 X-2,105-106$ & 235.25 & 54.04 & 22.36 & 23.60 \\
\hline $26 X-2,110-112$ & 235.31 & 53.33 & & \\
\hline $26 \mathrm{X}-2,136-137$ & 235.56 & 51.80 & 23.66 & 24.54 \\
\hline $26 \mathrm{X}-2,140-142$ & 235.60 & 50.00 & & \\
\hline $26 X-3,15-16$ & 235.85 & 46.59 & 23.74 & 29.67 \\
\hline $26 \mathrm{X}-3,20-22$ & 235.91 & 45.75 & & \\
\hline $26 \mathrm{X}-3,43-44$ & 236.13 & 36.12 & 28.80 & 35.08 \\
\hline $26 \mathrm{X}-3,50-52$ & 236.20 & 35.33 & & \\
\hline $26 X-3,75-76$ & 236.45 & 54.46 & 22.19 & 23.35 \\
\hline $26 \mathrm{X}-3,100-102$ & 236.70 & 59.13 & & \\
\hline $26 X-3,105-106$ & 236.75 & 57.92 & 16.12 & 25.96 \\
\hline $26 \mathrm{X}-3,110-112$ & 236.81 & 56.71 & & \\
\hline $26 X-3,136-137$ & 237.06 & 55.14 & 16.46 & 28.36 \\
\hline $26 X-3,140-142$ & 237.10 & 51.90 & & \\
\hline
\end{tabular}

APPENDIX (continued).

\begin{tabular}{|c|c|c|c|c|}
\hline $\begin{array}{l}\text { Core, section, } \\
\text { interval }(\mathrm{cm})\end{array}$ & $\begin{array}{l}\text { Depth } \\
\text { (mbsf) }\end{array}$ & $\underset{(\%)}{\mathrm{CaCO}_{3}}$ & $\begin{array}{l}\text { Opal } \\
(\%)\end{array}$ & $\begin{array}{l}\text { Other } \\
(\%)\end{array}$ \\
\hline $26 X-4,15-16$ & 237.35 & 57.04 & 12.04 & 30.92 \\
\hline $26 \mathrm{X}-4,20-22$ & 237.41 & 53.83 & & \\
\hline $26 X-4,43-44$ & 237.63 & 66.90 & 10.67 & 22.43 \\
\hline $26 X-4,50-52$ & 237.70 & 75.17 & & \\
\hline $26 X-4,75-76$ & 237.95 & 60.37 & 14.21 & 25.42 \\
\hline $26 X-4,100-102$ & 238.20 & 44.20 & & \\
\hline $26 \mathrm{X}-4,105-106$ & 238.25 & 33.03 & 27.18 & 39.79 \\
\hline $26 \mathrm{X}-4,110-112$ & 238.31 & 39.50 & & \\
\hline $26 X-4,136-137$ & 238.56 & 51.24 & 15.83 & 32.93 \\
\hline $26 X-5,15-16$ & 238.85 & 64. & 9.75 & 25.32 \\
\hline $26 \mathrm{X}-5,20-22$ & 238.91 & 58.00 & & \\
\hline $26 X-5,48-49$ & 239.18 & 69.04 & 8.52 & 22.44 \\
\hline $26 X-5,50-52$ & 239.20 & 69.50 & & \\
\hline $26 X-6,20-22$ & 240.41 & 83.91 & & \\
\hline $27 \mathrm{X}-1,119-120$ & 243.39 & 65.70 & 15.50 & 18.80 \\
\hline $27 \mathrm{X}-1,140-142$ & 243.60 & 45.00 & & \\
\hline $27 \mathrm{X}-1,145-146$ & 243.65 & 47.13 & 27.95 & 24.92 \\
\hline $27 X-2,15-16$ & 243.85 & 58.55 & 19.81 & 21.64 \\
\hline $27 X-2,45-46$ & 244.15 & 76.86 & 9.06 & 14.08 \\
\hline $27 X-2,50-52$ & 244.20 & 78.40 & & \\
\hline $27 X-2,64-68$ & 244.34 & 81.24 & 7.06 & 11.70 \\
\hline $27 X-2,100-102$ & 244.70 & 68.42 & & \\
\hline $27 X-2,105-106$ & 244.75 & 75.00 & 8.65 & 16.35 \\
\hline $27 X-2,110-112$ & 244.81 & 60.83 & & \\
\hline $27 X-2,135-136$ & 245.05 & 75.9 & 9.26 & 14.79 \\
\hline $27 X-2,140-142$ & 245. & 72.30 & & \\
\hline $27 X-3,15-16$ & 245.35 & 55.41 & 31.56 & 13.03 \\
\hline $27 \mathrm{X}-3,20-22$ & 245.41 & 53.58 & & \\
\hline $27 X-3,45-46$ & 245.65 & 36.30 & 44.80 & 18.90 \\
\hline $27 X-3,50-52$ & 245.70 & 32.50 & & \\
\hline $27 X-3,60-62$ & 245.80 & 25.92 & & \\
\hline $27 X-3,64-68$ & 245.86 & 27.34 & 52.01 & 20.65 \\
\hline $27 X-3,105-106$ & 246.25 & 46.70 & 36.66 & 16.64 \\
\hline $27 X-3,110-112$ & 246.31 & 46.66 & & \\
\hline $27 X-3,138-139$ & 246.58 & 75.22 & 10.38 & 14.40 \\
\hline $27 X-3,140-142$ & 246.60 & 68.70 & & \\
\hline $27 X-4,11-12$ & 246.81 & 76.01 & 9.36 & 14.63 \\
\hline $27 X-4,14-16$ & 246.85 & 73.75 & & \\
\hline $27 X-4,45-46$ & 247.15 & 74.41 & 7.95 & 17.64 \\
\hline $27 X-4,50-52$ & 247.20 & 72.67 & & \\
\hline $27 X-4,64-68$ & 247.36 & 65.49 & 12.36 & 22.15 \\
\hline $27 X-4,100-102$ & 247.70 & 77.92 & & \\
\hline $27 X-4,105-106$ & 247.75 & 80.82 & 5.39 & 13.79 \\
\hline $27 X-4,110-112$ & 247.81 & 78.16 & & \\
\hline $27 X-4,135-136$ & 248.05 & 72.79 & 7.69 & 19.52 \\
\hline $27 X-4,140-142$ & 248.10 & 72.80 & & \\
\hline $27 X-5,15-16$ & 248.35 & 61.09 & 12.54 & 26.37 \\
\hline $27 X-5,20-22$ & 248.41 & 49.66 & & \\
\hline $27 X-5,45-46$ & 248.65 & 62.51 & 13.63 & 23.86 \\
\hline $27 X-5,50-52$ & 248.70 & 76.80 & & \\
\hline $27 X-5,64-68$ & 248.84 & 74.19 & 7.02 & 18.79 \\
\hline $27 X-5,75-77$ & 248.95 & 64.33 & & \\
\hline $27 X-5,105-106$ & 249.25 & 61.80 & 11.86 & 26.34 \\
\hline $27 X-5,110-112$ & 249.31 & 70.66 & & \\
\hline $27 X-5,140-150$ & 249.65 & 74.40 & 13.20 & 12.40 \\
\hline $27 X-6,0-5$ & 249.72 & 73.37 & 6.82 & 19.81 \\
\hline $27 X-6,20-22$ & 249.91 & 80.08 & & \\
\hline $27 X-6,45-46$ & 250.15 & 86.52 & 3.74 & 9.74 \\
\hline $27 X-6,50-52$ & 250.20 & 87.10 & & \\
\hline $27 X-6,64-68$ & 250.34 & 79.56 & 5.20 & 15.24 \\
\hline $27 X-6,100-102$ & 250.70 & 83.25 & & \\
\hline $27 X-6,105-106$ & 250.75 & 82.74 & 3.18 & 14.08 \\
\hline $27 X-6,110-112$ & 250.81 & 78.33 & & \\
\hline $27 X-6,135-136$ & 251.05 & 75.41 & 7.18 & 17.41 \\
\hline $27 X-6,140-142$ & 251.10 & 87.20 & & \\
\hline $27 X-7,15-16$ & 251.35 & 85.67 & 3.20 & 11.13 \\
\hline $27 X-7,20-22$ & 251.41 & 84.00 & & \\
\hline $27 X-7,45-46$ & 251.65 & 76.17 & 6.42 & 17.41 \\
\hline $27 X-7,50-52$ & 251.70 & 78.20 & & \\
\hline $28 \mathrm{X}-1,20-22$ & 251.91 & 88.4 & & \\
\hline $28 \mathrm{X}-1,27-31$ & 251.97 & 91.6 & 1.50 & 6.89 \\
\hline $28 X-1,45-46$ & 252.15 & 92.5 & 1.42 & 6.08 \\
\hline $28 \mathrm{X}-1,49-51$ & 252.19 & 88.2 & & \\
\hline $28 \mathrm{X}-1,76-77$ & 252.36 & 90.60 & 1.07 & 8.33 \\
\hline $28 \mathrm{X}-1,99-101$ & 252.70 & 91.83 & & \\
\hline $28 \mathrm{X}-1,105-106$ & 252.75 & 90.13 & 1.42 & 8.45 \\
\hline $28 \mathrm{X}-1,110-112$ & 252.80 & 86.33 & & \\
\hline
\end{tabular}


APPENDIX (continued).

\begin{tabular}{|c|c|c|c|c|}
\hline $\begin{array}{l}\text { Core, section, } \\
\text { interval }(\mathrm{cm})\end{array}$ & $\begin{array}{l}\text { Depth } \\
\text { (mbsf) }\end{array}$ & $\begin{array}{c}\mathrm{CaCO}_{3} \\
(\%)\end{array}$ & $\begin{array}{l}\text { Opal } \\
(\%)\end{array}$ & $\begin{array}{l}\text { Other } \\
(\%)\end{array}$ \\
\hline $28 X-1,135-136$ & 253.05 & 92.61 & 1.51 & 5.88 \\
\hline $28 \mathrm{X}-1,140-142$ & 253.10 & 93.50 & & \\
\hline $28 \mathrm{X}-2,20-22$ & 253.41 & 89.16 & & \\
\hline $28 \mathrm{X}-2,27-31$ & 253.47 & 85.95 & 3.04 & 11.01 \\
\hline $28 X-2,45-46$ & 253.65 & 78.40 & 3.03 & 18.57 \\
\hline $28 \mathrm{X}-2,49-51$ & 253.69 & 80.20 & & \\
\hline $28 \times-2,76-77$ & 253.96 & 88.06 & 3.26 & 8.68 \\
\hline $28 X-2,99-101$ & 254.20 & 85.91 & & \\
\hline $28 \mathrm{X}-2,102-103$ & 254.22 & 78.84 & 6.79 & 14.37 \\
\hline $28 \mathrm{X}-2,110-112$ & 254.30 & 70.33 & & \\
\hline $28 X-2,135-136$ & 254.55 & 85.17 & 2.94 & 11.89 \\
\hline $28 X-2,140-142$ & 254.60 & 87.10 & & \\
\hline $28 X-3,0-5$ & 254.72 & 76.00 & 5.03 & 18.97 \\
\hline $28 X-3,15-16$ & 254.85 & 74.74 & 5.30 & 19.96 \\
\hline $28 \mathrm{X}-3,20-22$ & 254.91 & 72.08 & & \\
\hline $28 \mathrm{X}-3,27-31$ & 254.97 & 78.11 & 3.77 & 18.12 \\
\hline $28 X-3,45-46$ & 255.15 & 88.17 & 1.80 & 10.03 \\
\hline $28 \mathrm{X}-3,49-51$ & 255.19 & 91.08 & & \\
\hline $28 \times-3,75-76$ & 255.45 & 95.25 & 0.81 & 3.94 \\
\hline $28 X-3,99-101$ & 255.70 & 94.66 & & \\
\hline $28 \mathrm{X}-3,105-106$ & 255.75 & 93.93 & 0.88 & 5.19 \\
\hline $28 X-3,110-112$ & 255.80 & 93.75 & & \\
\hline $28 X-3,135-136$ & 256.05 & 87.01 & 1.64 & 11.35 \\
\hline $28 \mathrm{X}-3,140-142$ & 256.10 & 85.50 & & \\
\hline $28 X-4,20-22$ & 256.41 & 83.00 & & \\
\hline $28 X-4,27-31$ & 256.47 & 76.04 & 1.98 & 21.98 \\
\hline $28 X-4,45-46$ & 256.65 & 83.14 & 1.83 & 15.03 \\
\hline $28 X-4,49-51$ & 256.69 & 85.42 & & \\
\hline $28 X-4,75-76$ & 256.95 & 86.40 & 1.77 & 11.83 \\
\hline $28 \mathrm{X}-4,100-102$ & 257.20 & 88.92 & & \\
\hline $28 X-4,108-109$ & 257.28 & 90.84 & 1.70 & 7.46 \\
\hline $28 X-4,110-112$ & 257.31 & 89.54 & & \\
\hline $28 X-4,135-136$ & 257.55 & 91.29 & 1.97 & 6.74 \\
\hline $28 \mathrm{X}-4,140-142$ & 257.60 & 90.75 & & \\
\hline $28 X-5,20-22$ & 257.91 & 84.58 & & \\
\hline $28 X-5,27-31$ & 257.97 & 72.07 & 10.95 & 16.98 \\
\hline $28 X-5,45-46$ & 258.15 & 87.88 & 2.57 & 9.55 \\
\hline $28 X-5,49-51$ & 258.19 & 87.90 & & \\
\hline $28 X-5,75-76$ & 258.45 & 77.79 & 1.57 & 20.64 \\
\hline $28 \mathrm{X}-5,100-102$ & 258.70 & 87.83 & & \\
\hline $28 \mathrm{X}-5,105-106$ & 258.75 & 90.85 & 1.20 & 7.95 \\
\hline $28 \mathrm{X}-5,110-112$ & 258.81 & 90.75 & & \\
\hline $28 \mathrm{X}-5,135-136$ & 259.05 & 89.01 & 1.38 & 9.61 \\
\hline $28 X-5,140-142$ & 259.10 & 84.75 & & \\
\hline $28 \mathrm{X}-6,20-22$ & 259.41 & 80.41 & & \\
\hline $28 X-6,27-31$ & 259.47 & 83.06 & 1.56 & 15.38 \\
\hline $28 X-6,45-46$ & 259.65 & 86.32 & 3.02 & 10.66 \\
\hline $28 X-6,49-51$ & 259.69 & 85.20 & & \\
\hline $28 X-6,75-76$ & 259.95 & 87.63 & 1.83 & 10.54 \\
\hline $28 \mathrm{X}-6,99-101$ & 260.20 & 90.00 & & \\
\hline $28 \mathrm{X}-6,105-106$ & 260.25 & 87.59 & 1.54 & 10.87 \\
\hline $28 \times-6,110-112$ & 260.30 & 83.92 & & \\
\hline $28 \mathrm{X}-6,140-142$ & 260.60 & 83.50 & & \\
\hline $28 X-6,135-136$ & 260.61 & 85.72 & 3.41 & 10.87 \\
\hline $28 \times-7,20-22$ & 260.91 & 84.33 & & \\
\hline $28 X-7,27-31$ & 260.97 & 90.49 & 1.56 & 7.95 \\
\hline $28 X-7,45-46$ & 261.15 & 91.60 & 1.31 & 7.09 \\
\hline $28 X-7,49-51$ & 261.19 & 91.70 & & \\
\hline $29 X-1,15-16$ & 261.35 & 83.94 & 4.99 & 11.07 \\
\hline $29 X-1,20-22$ & 261.41 & 78.16 & & \\
\hline $29 \mathrm{X}-1,39-40$ & 261.59 & 75.71 & 4.90 & 19.39 \\
\hline $29 X-1,50-52$ & 261.70 & 79.58 & & \\
\hline $29 X-1,58-62$ & 261.78 & 84.79 & 3.77 & 11.44 \\
\hline $29 X-1,84-85$ & 262.04 & 80.56 & 4.12 & 15.32 \\
\hline $29 \mathrm{X}-1,90-92$ & 262.10 & 72.00 & & \\
\hline $29 X-1,105-106$ & 262.25 & 76.87 & 5.02 & 18.11 \\
\hline $29 \mathrm{X}-1,110-112$ & 262.31 & 76.08 & & \\
\hline $29 X-1,135-136$ & 262.55 & 81.51 & 3.71 & 14.78 \\
\hline $29 X-1,140-142$ & 262.60 & 81.25 & & \\
\hline $29 X-2,15-16$ & 262.85 & 79.00 & 1.22 & 19.78 \\
\hline $29 X-2,20-22$ & 262.91 & 92.16 & & \\
\hline $29 \times-2,44-45$ & 263.14 & 95.39 & 0.84 & 3.77 \\
\hline $29 X-2,50-52$ & 263.20 & 94.20 & & \\
\hline $29 X-2,58-62$ & 263.28 & 95.30 & 0.80 & 3.90 \\
\hline $29 X-2,83-84$ & 263.53 & 97.17 & 0.49 & 2.34 \\
\hline $29 X-2,90-92$ & 263.60 & 94.50 & & \\
\hline $29 X-2,105-106$ & 263.75 & 92.64 & 0.87 & 6.49 \\
\hline
\end{tabular}

APPENDIX (continued).

\begin{tabular}{|c|c|c|c|c|}
\hline $\begin{array}{l}\text { Core, section, } \\
\text { interval }(\mathrm{cm})\end{array}$ & $\begin{array}{l}\text { Depth } \\
\text { (mbsf) }\end{array}$ & $\begin{array}{c}\mathrm{CaCO}_{3} \\
(\%)\end{array}$ & $\begin{array}{l}\text { Opal } \\
(\%)\end{array}$ & $\begin{array}{l}\text { Other } \\
(\%)\end{array}$ \\
\hline $29 X-2,110-112$ & 263.81 & 91.50 & & \\
\hline $29 X-2,135-136$ & 264.05 & 86.72 & 2.19 & 11.09 \\
\hline $29 X-2,140-142$ & 264.10 & 79.50 & & \\
\hline $29 X-3,0-5$ & 264.22 & 88.03 & 1.41 & 10.56 \\
\hline $29 \mathrm{X}-3,20-22$ & 264.41 & 76.50 & & \\
\hline $29 X-3,45-46$ & 264.65 & 83.13 & 1.82 & 15.05 \\
\hline $29 X-3,50-52$ & 264.70 & 83.80 & & \\
\hline $29 X-3,58-62$ & 264.78 & 83.65 & 1.73 & 14.62 \\
\hline $29 X-3,90-92$ & 265.10 & 81.83 & & \\
\hline $29 \mathrm{X}-3,105-106$ & 265.25 & 85.87 & 1.52 & 12.61 \\
\hline $29 X-3,110-112$ & 265.31 & 85.08 & & \\
\hline $29 X-3,135-136$ & 265.55 & 86.52 & 1.58 & 11.90 \\
\hline $29 X-3,140-142$ & 265.60 & 86.83 & & \\
\hline $29 X-4,15-16$ & 265.85 & 86.63 & 1.52 & 11.85 \\
\hline $29 X-4,20-22$ & 265.91 & 86.66 & & \\
\hline $29 X-4,45-46$ & 266.15 & 92.14 & 0.93 & 6.93 \\
\hline $29 X-4,50-52$ & 266.20 & 91.00 & & \\
\hline $29 X-4,58-62$ & 266.28 & 90.89 & 1.42 & 7.69 \\
\hline $29 \mathrm{X}-4,90-92$ & 266.60 & 84.33 & & \\
\hline $29 X-4,105-106$ & 266.75 & 78.51 & 3.20 & 18.29 \\
\hline $29 X-4,110-112$ & 266.81 & 83.50 & & \\
\hline $29 X-4,135-136$ & 267.05 & 90.15 & 1.88 & 7.97 \\
\hline $29 X-4,140-142$ & 267.10 & 81.50 & & \\
\hline $29 X-5,15-16$ & 267.35 & 77.28 & 8.78 & 13.94 \\
\hline $29 X-5,20-22$ & 267.41 & 88.25 & & \\
\hline $29 X-5,45-46$ & 267.65 & 89.67 & 2.91 & 7.42 \\
\hline $29 X-5,50-52$ & 267.70 & 90.67 & & \\
\hline $29 X-5,58-62$ & 267.78 & 87.38 & 2.17 & 10.45 \\
\hline $29 X-5,90-92$ & 268.10 & 84.83 & & \\
\hline $29 X-5,105-106$ & 268.25 & 82.05 & 1.53 & 16.42 \\
\hline $29 X-5,110-112$ & 268.31 & 88.16 & & \\
\hline $29 X-5,135-136$ & 268.55 & 86.06 & 2.39 & 11.55 \\
\hline $29 X-5,140-142$ & 268.60 & 91.10 & & \\
\hline $29 X-6,15-16$ & 268.85 & 86.67 & 1.78 & 11.55 \\
\hline $29 X-6,20-22$ & 268.91 & 86.83 & & \\
\hline $29 X-6,45-46$ & 269.15 & 79.11 & 2.79 & 18.10 \\
\hline $29 X-6,50-52$ & 269.20 & 80.20 & & \\
\hline $29 \mathrm{X}-6,58-62$ & 269.28 & 82.62 & 3.06 & 14.32 \\
\hline $29 X-6,90-92$ & 269.60 & 65.58 & & \\
\hline $29 \mathrm{X}-6,105-106$ & 269.75 & 81.06 & 5.91 & 13.03 \\
\hline $29 X-6,130-131$ & 270.00 & 84.37 & 4.72 & 10.91 \\
\hline $29 X-7,15-16$ & 270.35 & 80.06 & 5.69 & 14.25 \\
\hline $29 X-7,20-22$ & 270.41 & 78.66 & & \\
\hline $29 X-7,45-46$ & 270.65 & 82.17 & 3.94 & 13.89 \\
\hline $29 \times-7,50-52$ & 270.70 & 85.42 & & \\
\hline $30 \times-1,15-16$ & 270.85 & 89.81 & 1.60 & 8.59 \\
\hline $30 \mathrm{X}-1,20-22$ & 270.90 & 89.50 & & \\
\hline $30 X-1,44-45$ & 271.14 & 94.69 & 2.07 & 3.24 \\
\hline $30 X-1,50-52$ & 271.20 & 92.30 & & \\
\hline $30 \times-1,76-77$ & 271.46 & 84.17 & 5.23 & 10.60 \\
\hline $30 X-1,95-99$ & 271.65 & 74.21 & 6.06 & 19.73 \\
\hline $30 X-1,100-102$ & 271.70 & 66.67 & & \\
\hline $30 \mathrm{X}-1,110-112$ & 271.81 & 71.16 & & \\
\hline $30 X-1,135-136$ & 272.05 & 76.56 & 4.68 & 18.76 \\
\hline $30 \mathrm{X}-1,140-142$ & 272.10 & 76.83 & & \\
\hline $30 X-2,14-15$ & 272.34 & 85.17 & 4.14 & 10.69 \\
\hline $30 \mathrm{X}-2,20-22$ & 272.41 & 84.58 & & \\
\hline $30 X-2,46-47$ & 272.66 & 81.69 & 3.33 & 14.98 \\
\hline $30 X-2,50-52$ & 272.70 & 83.25 & & \\
\hline $30 X-2,75-75$ & 272.95 & 66.93 & 8.73 & 24.34 \\
\hline $30 X-2,95-99$ & 273.15 & 75.17 & 4.99 & 19.84 \\
\hline $30 X-2,100-102$ & 273.20 & 75.23 & & \\
\hline $30 X-2,110-112$ & 273.31 & 73.08 & & \\
\hline $30 X-2,133-134$ & 273.53 & 69.21 & 8.85 & 21.94 \\
\hline $30 \times-2,137-139$ & 273.57 & 69.20 & & \\
\hline $30 X-2,140-150$ & 273.59 & 4.40 & & \\
\hline $30 \mathrm{X}-3,0-5$ & 273.60 & 78.73 & 3.93 & 17.34 \\
\hline $30 X-3,20-22$ & 273.80 & 83.16 & & \\
\hline $30 X-3,43-44$ & 274.03 & 91.39 & 1.23 & 7.38 \\
\hline $30 X-3,50-52$ & 274.10 & 92.60 & & \\
\hline $30 X-3,75-76$ & 274.35 & 94.15 & 0.81 & 5.04 \\
\hline $30 \times-3,95-99$ & 274.55 & 93.95 & 0.71 & 5.34 \\
\hline $30 X-3,100-102$ & 274.60 & 93.49 & & \\
\hline $30 X-3,110-112$ & 274.70 & 93.25 & & \\
\hline $30 \times-3,135-136$ & 274.85 & 89.18 & & \\
\hline $30 \times-3,140-142$ & 275.00 & 87.42 & & \\
\hline $30 X-4,15-16$ & 275.25 & 87.36 & & \\
\hline
\end{tabular}


APPENDIX (continued).

\begin{tabular}{|c|c|c|c|c|}
\hline $\begin{array}{l}\text { Core, section, } \\
\text { interval }(\mathrm{cm})\end{array}$ & $\begin{array}{l}\text { Depth } \\
\text { (mbsf) }\end{array}$ & $\begin{array}{c}\mathrm{CaCO}_{3} \\
(\%)\end{array}$ & $\begin{array}{l}\text { Opal } \\
(\%)\end{array}$ & $\begin{array}{c}\text { Other } \\
(\%)\end{array}$ \\
\hline $30 X-4,20-22$ & 275.30 & 80.91 & & \\
\hline $30 X-4,50-52$ & 275.60 & 79.70 & & \\
\hline $30 X-4,100-102$ & 276.10 & 82.82 & & \\
\hline $30 X-4,110-112$ & 276.20 & 82.91 & & \\
\hline $30 X-4,140-142$ & 276.50 & 80.92 & & \\
\hline $30 X-5,20-22$ & 276.80 & 86.91 & & \\
\hline $30 X-5,50-52$ & 277.10 & 89.70 & & \\
\hline $30 X-6,20-22$ & 277.50 & 88.91 & & \\
\hline $30 X-7,50-52$ & 278.20 & 84.10 & & \\
\hline $30 X-7,100-102$ & 278.70 & 68.14 & & \\
\hline $30 X-7,110-112$ & 278.80 & 79.17 & & \\
\hline $30 X-7,140-142$ & 279.10 & 84.10 & & \\
\hline $30 X-8,20-22$ & 279.40 & 89.75 & & \\
\hline $30 X-8,50-52$ & 279.70 & 88.75 & & \\
\hline $30 X-8,110-112$ & 280.30 & 86.25 & & \\
\hline $31 X-1,20-22$ & 280.41 & 84.75 & & \\
\hline $30 X-8,140-142$ & 280.60 & 90.66 & & \\
\hline $31 X-1,100-102$ & 281.20 & 81.48 & & \\
\hline $31 X-1,110-112$ & 281.31 & 81.58 & & \\
\hline $31 X-2,19-21$ & 281.90 & 89.66 & & \\
\hline $31 X-2,100-102$ & 282.70 & 86.24 & & \\
\hline $31 X-2,110-112$ & 282.81 & 86.66 & & \\
\hline $31 X-3,19-21$ & 283.40 & 92.16 & & \\
\hline $31 X-3,100-102$ & 284.20 & 90.57 & & \\
\hline $31 X-3,110-112$ & 284.31 & 89.66 & & \\
\hline $31 X-4,19-21$ & 284.90 & 94.00 & & \\
\hline $31 X-4,100-102$ & 285.70 & 95.49 & & \\
\hline $31 X-4,110-112$ & 285.81 & 93.25 & & \\
\hline $31 X-5,19-21$ & 286.40 & 83.91 & & \\
\hline $31 X-5,100-102$ & 287.20 & 89.91 & & \\
\hline $31 X-5,110-112$ & 287.30 & 86.25 & & \\
\hline $31 X-6,19-21$ & 287.90 & 82.33 & & \\
\hline $31 X-6,100-102$ & 288.70 & 84.48 & & \\
\hline $31 X-6,110-112$ & 288.80 & 84.50 & & \\
\hline $32 X-1,20-22$ & 289.90 & 93.08 & & \\
\hline $32 X-1,100-102$ & 290.70 & 84.15 & & \\
\hline $32 X-1,110-112$ & 290.80 & 85.00 & & \\
\hline $32 X-2,20-22$ & 291.40 & 84.75 & & \\
\hline $32 X-2,100-102$ & 292.20 & 86.99 & & \\
\hline $32 X-2,110-112$ & 292.30 & 86.50 & & \\
\hline $32 X-3,20-22$ & 292.91 & 85.08 & & \\
\hline $32 X-3,100-102$ & 293.70 & 90.91 & & \\
\hline $32 X-3,110-112$ & 293.80 & 90.25 & & \\
\hline $32 X-4,20-22$ & 294.41 & 95.33 & & \\
\hline $32 X-4,100-102$ & 295.20 & 91.49 & & \\
\hline $32 X-4,110-112$ & 295.30 & 94.00 & & \\
\hline $32 X-5,20-22$ & 295.91 & 84.70 & & \\
\hline $32 X-5,100-102$ & 296.70 & 68.89 & & \\
\hline $32 X-5,110-112$ & 296.80 & 65.75 & & \\
\hline $32 X-6,20-22$ & 297.41 & 69.25 & & \\
\hline $32 X-6,100-102$ & 298.20 & 87.74 & & \\
\hline $32 X-6,110-112$ & 298.30 & 85.75 & & \\
\hline $32 X-7,20-22$ & 298.91 & 90.66 & & \\
\hline $33 \mathrm{X}-1,20-22$ & 299.41 & 92.66 & & \\
\hline $33 \mathrm{X}-1,100-102$ & 300.20 & 92.99 & & \\
\hline $33 \mathrm{X}-1,110-112$ & 300.30 & 97.83 & & \\
\hline $33 \mathrm{X}-2,20-22$ & 300.91 & 73.25 & & \\
\hline $33 X-2,100-102$ & 301.70 & 79.56 & & \\
\hline $33 X-2,110-112$ & 301.80 & 86.16 & & \\
\hline $33 \mathrm{X}-3,20-22$ & 302.41 & 88.16 & & \\
\hline $33 \mathrm{X}-3,100-102$ & 303.20 & 88.74 & & \\
\hline $33 X-3,110-112$ & 303.30 & 91.75 & & \\
\hline $33 \mathrm{X}-4,100-102$ & 304.70 & 87.57 & & \\
\hline $33 X-4,110-112$ & 304.80 & 89.41 & & \\
\hline $33 X-5,20-22$ & 305.41 & 94.41 & & \\
\hline $33 X-5,100-102$ & 306.20 & 86.07 & & \\
\hline $33 X-5,110-112$ & 306.30 & 86.91 & & \\
\hline $33 X-6,20-22$ & 306.91 & 82.16 & & \\
\hline $33 X-6,100-102$ & 307.70 & 62.88 & & \\
\hline $33 X-6,110-112$ & 307.80 & 64.75 & & \\
\hline $33 X-7,20-22$ & 308.41 & 84.33 & & \\
\hline $34 X-1,20-22$ & 308.91 & 93.33 & & \\
\hline $34 X-1,100-102$ & 309.70 & 92.99 & & \\
\hline $34 X-1,110-112$ & 309.80 & 94.00 & & \\
\hline $34 X-2,20-22$ & 310.41 & 90.00 & & \\
\hline $34 X-2,100-102$ & 311.20 & 88.07 & & \\
\hline $34 X-2,110-112$ & 311.30 & 91.50 & & \\
\hline
\end{tabular}

APPENDIX (continued).

\begin{tabular}{|c|c|c|c|c|}
\hline $\begin{array}{l}\text { Core, section, } \\
\text { interval }(\mathrm{cm})\end{array}$ & $\begin{array}{l}\text { Depth } \\
\text { (mbsf) }\end{array}$ & $\underset{(\%)}{\mathrm{CaCO}_{3}}$ & $\begin{array}{c}\text { Opal } \\
(\%)\end{array}$ & $\begin{array}{c}\text { Other } \\
(\%)\end{array}$ \\
\hline $34 X-3,20-22$ & 311.91 & 90.91 & & \\
\hline $34 \mathrm{X}-3,100-102$ & 312.70 & 93.07 & & \\
\hline $34 X-3,110-112$ & 312.80 & 93.66 & & \\
\hline $34 X-4,20-22$ & 313.41 & 92.66 & & \\
\hline $34 X-4,100-102$ & 314.20 & 87.99 & & \\
\hline $34 \mathrm{X}-4,110-112$ & 314.30 & 92.41 & & \\
\hline $34 X-5,20-22$ & 314.91 & 92.83 & & \\
\hline $34 X-5,100-102$ & 315.70 & 82.82 & & \\
\hline $34 X-5,110-112$ & 315.80 & 83.20 & & \\
\hline $34 X-6,20-22$ & 316.41 & 86.83 & & \\
\hline $34 \mathrm{X}-6,100-102$ & 317.20 & 86.07 & & \\
\hline $34 X-6,110-112$ & 317.30 & 85.58 & & \\
\hline $34 X-7,20-22$ & 317.91 & 84.91 & & \\
\hline $35 \mathrm{X}-1,20-22$ & 318.41 & 88.16 & & \\
\hline $35 \mathrm{X}-1,100-102$ & 319.20 & 78.73 & & \\
\hline $35 \mathrm{X}-1,110-112$ & 319.31 & 78.16 & & \\
\hline $35 X-2,20-22$ & 319.91 & 68.66 & & \\
\hline $35 X-2,100-102$ & 320.70 & 71.14 & & \\
\hline $35 X-2,110-112$ & 320.81 & 65.58 & & \\
\hline $35 X-3,20-22$ & 321.41 & 53.91 & & \\
\hline $35 X-3,100-102$ & 322.20 & 39.70 & & \\
\hline $35 \mathrm{X}-3,110-112$ & 322.31 & 45.41 & & \\
\hline $35 X-4,20-22$ & 322.91 & 55.66 & & \\
\hline $35 \mathrm{X}-4,100-102$ & 323.70 & 46.04 & & \\
\hline $35 X-4,110-114$ & 323.82 & 46.75 & & \\
\hline $35 X-5,20-22$ & 324.41 & 67.57 & & \\
\hline $35 X-5,100-102$ & 325.20 & 69.39 & & \\
\hline $35 X-5,110-112$ & 325.31 & 51.85 & & \\
\hline $35 X-6,20-22$ & 325.91 & 81.33 & & \\
\hline $35 X-6,100-102$ & 326.70 & 83.48 & & \\
\hline $35 X-6,110-112$ & 326.81 & 83.91 & & \\
\hline $35 X-7,20-22$ & 327.41 & 81.75 & & \\
\hline $36 \mathrm{X}-1,20-22$ & 327.91 & 91.50 & & \\
\hline $36 \mathrm{X}-1,100-102$ & 328.70 & 90.49 & & \\
\hline $36 \mathrm{X}-1,110-112$ & 328.81 & 91.54 & & \\
\hline $36 \mathrm{X}-2,20-22$ & 329.41 & 94.58 & & \\
\hline $36 \mathrm{X}-2,97-99$ & 330.17 & 91.24 & & \\
\hline $36 X-2,110-112$ & 330.31 & 92.66 & & \\
\hline $36 X-3,20-22$ & 330.91 & 76.16 & & \\
\hline $37 X-1,20-22$ & 337.41 & 84.50 & & \\
\hline $37 \mathrm{X}-1,110-112$ & 338.31 & 82.50 & & \\
\hline $37 X-2,20-22$ & 338.91 & 76.75 & & \\
\hline $37 X-2,100-102$ & 339.70 & 81.15 & & \\
\hline $37 X-2,110-112$ & 339.81 & 78.75 & & \\
\hline $37 X-3,20-22$ & 340.41 & 89.41 & & \\
\hline $37 X-3,100-102$ & 341.20 & 89.92 & & \\
\hline $39 X-1,100-102$ & 357.20 & 91.16 & & \\
\hline $39 X-2,100-102$ & 358.70 & 89.07 & & \\
\hline $39 X-3,100-102$ & 360.20 & 92.16 & & \\
\hline $39 X-4,100-102$ & 361.70 & 91.99 & & \\
\hline $39 X-5,100-102$ & 363.20 & 92.91 & & \\
\hline $39 X-6,100-102$ & 364.70 & 93.24 & & \\
\hline $40 X-1,98-100$ & 366.68 & 87.82 & & \\
\hline $40 X-2,98-100$ & 368.18 & 81.57 & & \\
\hline $40 X-3,98-100$ & 369.68 & 81.73 & & \\
\hline $40 X-4,98-100$ & 371.18 & 81.06 & & \\
\hline $40 X-5,98-100$ & 372.68 & 78.40 & & \\
\hline $40 X-6,98-100$ & 374.18 & 79.90 & & \\
\hline $41 X-1,101-103$ & 376.21 & 89.15 & & \\
\hline $41 X-2,101-103$ & 377.71 & 79.73 & & \\
\hline $41 X-3,101-103$ & 379.21 & 79.48 & & \\
\hline $41 X-4,101-103$ & 380.71 & 85.99 & & \\
\hline $41 X-5,101-103$ & 382.21 & 85.99 & & \\
\hline $41 X-6,101-103$ & 383.71 & 79.56 & & \\
\hline $42 X-2,99-101$ & 387.19 & 75.14 & & \\
\hline $42 X-4,99-101$ & 390.19 & 90.99 & & \\
\hline $42 X-6,99-101$ & 392.76 & 82.40 & & \\
\hline $43 X-1,100-102$ & 395.20 & 89.91 & & \\
\hline $43 X-4,100-102$ & 398.70 & 81.32 & & \\
\hline $43 \times-7,50-52$ & 401.80 & 84.57 & & \\
\hline $45 X-2,101-103$ & 415.71 & 88.57 & & \\
\hline $46 \mathrm{X}-2,101-103$ & 425.21 & 94.16 & & \\
\hline $46 \mathrm{X}-3,101-103$ & 426.71 & 82.15 & & \\
\hline $46 X-4,94-96$ & 428.14 & 84.15 & & \\
\hline $47 X-2,90-92$ & 434.60 & 73.89 & & \\
\hline $47 X-4,90-92$ & 437.60 & 71.72 & & \\
\hline $48 X-1,100-102$ & 442.70 & 85.90 & & \\
\hline
\end{tabular}


P. N. FROELICH ET AL.

APPENDIX (continued).

\begin{tabular}{|c|c|c|c|c|}
\hline $\begin{array}{l}\text { Core, section, } \\
\text { interval }(\mathrm{cm})\end{array}$ & $\begin{array}{l}\text { Depth } \\
\text { (mbsf) }\end{array}$ & $\begin{array}{c}\mathrm{CaCO}_{3} \\
(\%)\end{array}$ & $\begin{array}{l}\text { Opal } \\
(\%)\end{array}$ & $\begin{array}{l}\text { Other } \\
(\%)\end{array}$ \\
\hline $48 X-3,100-102$ & 445.70 & 79.73 & & \\
\hline $49 X-2,83-85$ & 453.53 & 73.73 & & \\
\hline $49 X-5,135-137$ & 458.55 & 79.73 & & \\
\hline $50 X-1,50-51$ & 461.20 & 80.90 & & \\
\hline $52 X-1,100-102$ & 473.20 & 85.57 & & \\
\hline $52 X-4,98-100$ & 477.68 & 83.57 & & \\
\hline $53 X-2,115-117$ & 484.35 & 88.74 & & \\
\hline $54 \mathrm{X}-1,103-105$ & 492.23 & 87.07 & & \\
\hline $54 \mathrm{X}-3,100-102$ & 495.20 & 89.49 & & \\
\hline $54 X-5,100-102$ & 498.20 & 84.07 & & \\
\hline $55 X-2,70-75$ & 502.90 & 86.07 & & \\
\hline $55 X-4,54-56$ & 505.74 & 78.07 & & \\
\hline $55 X-5,95-97$ & 507.65 & 88.90 & & \\
\hline $55 X-6,74-76$ & 508.94 & 90.10 & & \\
\hline $56 X-2,25-27$ & 511.95 & 86.40 & & \\
\hline $56 \mathrm{X}-3,57-59$ & 513.77 & 88.40 & & \\
\hline $56 \times-4,62-64$ & 515.32 & 80.81 & & \\
\hline $57 X-2,93-95$ & 522.13 & 88.32 & & \\
\hline $57 \mathrm{X}-\mathrm{CC}, 26-28$ & 523.86 & 78.23 & & \\
\hline $58 \mathrm{X}-2,78-80$ & 531.48 & 85.07 & & \\
\hline $58 X-3,102-104$ & 533.22 & 85.40 & & \\
\hline $58 X-5,54-56$ & 535.74 & 86.57 & & \\
\hline $58 X-6,42-44$ & 537.12 & 82.23 & & \\
\hline $59 X-1,103-105$ & 539.73 & 86.32 & & \\
\hline $59 X-2,123-125$ & 541.43 & 86.82 & & \\
\hline $59 \times-3,125-127$ & 542.95 & 86.32 & & \\
\hline $60 X-3,40-42$ & 551.60 & 86.32 & & \\
\hline $60 X-4,48-50$ & 553.18 & 90.07 & & \\
\hline $60 X-6,10-12$ & 555.80 & 86.32 & & \\
\hline $61 X-2,78-80$ & 559.98 & 84.57 & & \\
\hline $62 X-2,122-124$ & 569.92 & 75.14 & & \\
\hline $62 X-3,116-118$ & 571.36 & 85.49 & & \\
\hline $62 X-4,109-111$ & 572.79 & 76.98 & & \\
\hline $62 X-5,135-137$ & 574.55 & 78.98 & & \\
\hline $63 \mathrm{X}-1,130-132$ & 578.00 & 85.07 & & \\
\hline $63 X-2,115-117$ & 579.35 & 86.40 & & \\
\hline $63 X-3,136-138$ & 581.06 & 80.40 & & \\
\hline $63 X-4,63-65$ & 581.83 & 80.98 & & \\
\hline $63 X-5,100-102$ & 583.70 & 87.57 & & \\
\hline $64 X-1,1-3$ & 586.21 & 80.90 & & \\
\hline $64 X-3,74-76$ & 589.94 & 89.57 & & \\
\hline $64 X-C C, 31-33$ & 590.79 & 68.39 & & \\
\hline $65 X-1,137-139$ & 597.07 & 81.23 & & \\
\hline $65 X-2,134-136$ & 598.54 & 79.65 & & \\
\hline $65 X-3,90-92$ & 599.60 & 71.81 & & \\
\hline $66 x-1,5-7$ & 605.25 & 74.98 & & \\
\hline $66 X-C C, 12-14$ & 605.91 & 80.90 & & \\
\hline $67 X-1,108-110$ & 615.78 & 90.99 & & \\
\hline $68 X-1,126-128$ & 625.46 & 78.40 & & \\
\hline $68 X-2,77-79$ & 626.47 & 79.98 & & \\
\hline $69 X-1,60-62$ & 634.30 & 89.99 & & \\
\hline $70 x-1,4-6$ & 643.24 & 80.06 & & \\
\hline $71 X-1,105-107$ & 653.75 & 74.31 & & \\
\hline $71 X-2,98-100$ & 655.18 & 78.40 & & \\
\hline $71 X-3,55-57$ & 656.25 & 68.97 & & \\
\hline $71 X-4,104-105$ & 663.24 & 86.40 & & \\
\hline $72 X-2,93-95$ & 664.63 & 84.90 & & \\
\hline $72 X-3,114-115$ & 666.34 & 59.05 & & \\
\hline
\end{tabular}

